UNIVERSIDADE DE SÃO PAULO

INSTITUTO DE GEOCIÊNCIAS

ANDRÉ GIANOTTI STERN

Caracterização de depósitos fluviais de grandes e pequenos rios no Quaternário da Amazônia: Terraços de Terra Firme no Médio Rio Solimões, Amazonas (AM) e a Formação Boa Vista, Roraima (RR) 


\section{ANDRÉ GIANOTTI STERN}

Caracterização de depósitos fluviais de grandes e pequenos rios no Quaternário da Amazônia: Terraços de Terra Firme no Médio Rio Solimões, Amazonas (AM) e a Formação Boa Vista, Roraima (RR)

Tese apresentada ao Programa de Geociências (Geoquímica e Geotectônica) do Instituto de Geociências da Universidade de São Paulo para obtenção do título de Doutor em Ciências.

Área de concentração: Geotectônica

Orientador: Prof. Dr. Renato Paes de Almeida 
Somente dois anos após a publicação, autorizo a reprodução e divulgação total ou parcial deste trabalho, por qualquer meio convencional ou eletrônico, para fins de estudo e pesquisa, desde que citada a fonte.

Serviço de Biblioteca e Documentação do IGc/USP

Ficha catalográfica gerada automaticamente com dados fornecidos pelo autor via programa desenvolvido pela Seção Técnica de Informática do ICMC-USP

\section{Stern, André Gianotti}

Caracterização de depósitos fluviais de grandes e pequenos rios no Quaternário da Amazônia: Terraços de Terra Firme no Médio Rio Solimões, Amazonas (AM) e a Formação Boa Vista, Roraima (RR) / André Gianotti Stern; orientador, Renato Paes de Almeida. - São Paulo, 2019. $122 \mathrm{p}$.

Tese (Doutorado em Geoquímica e Geotectônica) - Instituto de Geociências, Universidade de São Paulo, 2019

Versão original

1. Rios Solimões, Amazonas, Içá, Branco e Tacutu. 2. Quaternário e fácies. 3. Sedimentologia. 4. Canais fluviais. I. Paes de Almeida, Renato, orient. II. Título.

Bibliotecários responsáveis pela estrutura de catalogação da publicação:

Sonia Regina Yole Guerra - CRB-8/4208 | Anderson de Santana - CRB-8/6658 
Caracterização de depósitos fluviais de grandes e pequenos rios no Quaternário da Amazônia: Terraços de terra firme no Médio Rio Solimões, Amazonas (AM) e a formação Boa Vista, Roraima (RR)

\section{ANDRÉ GIANOTTI STERN}

Orientador: Prof. Dr. Renato Paes de Almeida

TESE DE Doutorado

$\mathbf{N}^{0} 619$

COMISSÃO JULGADORA

Dr. Renato Paes de Almeida

Dra. Ana Maria Góes

Dr. André Pires Negrão

Dr. Vinícius Ribau Mendes

Dr. Mario Luis Assine

Dr. Ernesto Luiz Correa Lavina

SÃO PAULO

2020 


\section{AGRADECIMENTOS}

Após estes longos anos de muito aprendizado, estou grato à ajuda, à paciência e ao companheirismo de muitas e muitas pessoas, sem as quais eu jamais teria chegado ao fim da jornada.

Agradeço ao amigo, compadre, professor e orientador, Prof. Dr. Renato Paes de Almeida, pela paciência e pela confiança que me depositou.

Agradeço aos queridos Ana Góes, André Marconato, André Sawakuchi, Bernardo Freitas, Chico Bill, Cristiano Galeazzi, Diego Souza, Ederon Marques, Gabriel Kullman, Kenneth Campbell, Larissa Tamura, Liliane Janikian, Marlei Chamani e Nazaré Almeida.

À profissional, competente e querida equipe dos laboratórios de sedimentologia e petrografia sedimentar Jordana Zampelli e Luciana Nogueira; a Thays Desirré, do laboratório de espectrometria gama e luminescência, e à querida equipe do laboratório de análise de bacias sedimentares (Mocó).

Finalmente, agradeço o apoio de minha família, à qual dedico este volume. 


\section{RESUMO}

STERN, André Gainotti. Caracterização de depósitos fluviais de grandes e pequenos rios no Quaternário da Amazônia: Terraços de Terra Firme no Médio Rio Solimões, Amazonas (AM) e a Formação Boa Vista, Roraima (RR). 2019. 122 p. Tese (Doutorado em Geoquímica e Geotectônica) - Instituto de Geociências, Universidade de São Paulo, São Paulo, 2007.

Grandes rios têm um papel importante no transporte de sedimentos continentais para bacias oceânicas e são considerados grandes modeladores do relevo da Terra. Trata-se de sistemas hidrológicos com bacias de expressão regional, longos canais principais e enorme descarga de água e sedimentos. Também têm grandes implicações na biota, atuando como barreiras biogeográficas durante a evolução da biodiversidade através do Neógeno. Modelos conceituais hidrogeológicos que procuram reconstituir o ambiente de formação desses grandes rios e reconhecê-los no registro geológico têm grande influência na formulação de hipóteses e na interpretação de dados sobre biologia evolutiva, paleontologia, paleooceanografia e paleoclima, em escalas regional e continental.

Sistemas fluviais do tipo anabranching são predominantes entre os 40 maiores rios da Terra, mas a escassez de estudos em sistemas ativos e de depósitos quaternários correspondentes prejudica o estabelecimento de critérios distintivos e considerações sobre preservação seletiva de fácies e elementos arquiteturais. Um amplo sistema de terraços, antes mapeado como Formação Içá, registra a deposição de sistemas de tipo anabranching durante o Pleistoceno tardio na Amazônia Central. Esse sistema pode ser relacionado aos sistemas fluviais de rios ativos da Amazônia Central e é um alvo ideal para estudos de arquitetura sedimentar fluvial preservada em sistemas anabranching e de grande porte. A integração entre levantamentos sedimentológicos com estudos de morfologia de estruturas preservadas em planta, análises de proveniência, granulometria e datação por OSL permite relacionar as feições observadas em afloramentos à preservação de elementos dos sistemas de ativos e ampliar o conhecimento sobre os depósitos de rios anabranching de grande porte.

A tese apresenta estudo de depósitos fluviais pleistocênicos na Amazônia Central e em exposições de depósitos de idade similar em sistemas eólicos-fluviais característicos pertencentes à Formação Boa Vista, no norte do estado de Roraima. Está ordenada em três artigos em preparação. O primeiro aborda a estratigrafia, paleocorrentes, paleodescargas e a evolução paleogeográfica dos sistemas de terraços de Terra Firme pleistocênicos da Amazônia Central. O segundo, a sedimentologia e a arquitetura deposicional de exposições na mesma região. O terceiro, as exposições de sedimentos pleistocênicos da Formação Boa Vista.

Os estudos em escala regional resultaram no reconhecimento de três estágios principais de desenvolvimento de terraços, com relações de corte indicando eventos de queda do nível de base. Eventos de queda no nível de base devido ao reajuste do perfil do rio a montante para o nível do mar, ao aumento da descarga do rio principal ou ao efeito combinado de ambos os processos resultaram em erosão de vales em sedimentos antigos, causando a incisão de tributários e a expansão da Floresta de Terra Firme a partir de áreas de topografias mais altas, onde a biota já estava isolada em interflúvios separados pelos mesmos rios.

Com relação à Formação Boa Vista, nossos dados revelam um cenário paleogeográfico completamente distinto, ainda que com idades de deposição semelhantes. Os lateritas que compõem a Formação Boa Vista inferior (FBVI) resultam do intemperismo in situ de rochas pré-cambrianas e mesozoicas afetadas por condições climáticas úmidas e quentes. A 
Formação contém também depósitos quartzosos de granulação fina e arenitos de quartzo subordinados, formados por fluxo de gravitacional, retrabalhados por inundações e com depósitos eólicos intercalados. Há depósitos de pequenos canais fluviais na base da unidade e associados a uma superfície de erosão, correspondendo à instalação de uma rede de drenagem após um período de erosão. As paleocorrentes nos depósitos de canal mostram uma direção de fluxo norte-nordeste, indicando que essa rede fazia parte do sistema de drenagem ProtoBerbice. Os depósitos eólicos correspondem ao retrabalhamento de sedimentos da Formação Boa Vista e mostram uma assinatura granulométrica distinta, permitindo diferenciá-los. A datação OSL da unidade superior da Formação Boa Vista situa a deposição dessa unidade no Pleistoceno-Holoceno Superior, e os depósitos eólicos como as dunas de Mucajaí estão correlacionadas a outros depósitos eólicos localizados em outras partes da Amazônia, indicando a correlação das condições climáticas mais secas durante o LGM. Marca também a idade da captura e a consequente morte do rio Proto-Berbice pelo Médio-Baixo Rio Branco, mas esse evento pode não de ter tido grande efeito na deposição da Formação Boa Vista, com a deposição eólica e não eólica continuando após a captura.

Palavras-chave: Rios Solimões, Amazonas, Içá, Branco e Tacutu. Quaternário e fácies. Sedimentologia. Canais fluviais. 


\begin{abstract}
STERN, André Gainotti. Characterization of fluvial deposits of large and small rivers in the Quaternary of the Amazon: Terra Firme Terraces in the Middle Rio Solimões, Amazonas (AM) and the Boa Vista Formation, Roraima (RR). 2019. 122 p. Tese (Doutorado em Geoquímica e Geotectônica) - Instituto de Geociências, Universidade de São Paulo, São Paulo, 2007.
\end{abstract}

Large rivers play an important role in transporting continental sediments into ocean basins, and are considered to be a major landform shapers. They represent large hydrological systems with regional expression basins, long main channels and large discharge of water and sediment. They also have major implications for biota, acting as biogeographic barriers during the evolution of biodiversity through the Neogene. Hydrogeological conceptual models that try to rebuild the environmental formation of these large rivers and the recognition in the rock records have great influence on the hypotheses formulation and biology, paleontology, paleooceanography and paleoclimate evolutionary interpretations at regional and continental scale.

Anabranching river systems are dominant among the 40 largest rivers on Earth, even though the scarcity of studies in active systems and in related quaternary deposits hampers the establishment of diagnostic criteria and the understanding of preservational biases of facies and architectural elements. A wide system of terraces, formerly mapped as Içá formation, record deposition of anabranching systems during the Late Pleistocene in Central Amazonia. That system is related to the active rivers in the region, being an ideal target for studies of the preserved depositional architecture of large anabranching rivers. The integration of sedimentological surveys to studies of plan view preserved bar morphology, provenance analyzes, particle size analysis, OSL dating and facies analysis and sedimentary architecture, allow relate these features observed in outcrops to the active drainage systems in the region and increase the knowledge and information for the modeling. The integration of sedimentological surveys with studies of plant preserved structure morphology, provenance, granulometry and OSL dating allows to relate the features observed in outcrops to the preservation elements of active system and to increase the knowledge about large anabranching river deposits.

The thesis presents a study of Pleistocene fluvial deposits from the central Amazon and in eolian-fluvial systems deposits of similar age in the Boa Vista Formation, in the northernmost state of Roraima. It is organized into three papers, two still in preparation. The first is about the stratigraphy, paleocurrents, paleodesigns and paleogeographic evolution of the central Amazonian Pleistocene Terra Firme terrace systems. The second is about the sedimentology and depositional architecture of outcrops in the same region. The third is related to the Pleistocene sedimentary Boa Vista Formation.

Regional scale studies have resulted in the recognition of three main stages of terrace development, with cutoff ratios indicating base level drop events. Baseline drop events due to readjustment of the upstream river profile to sea level, an increase in main river discharge or the combined effect of both processes resulted in erosion of valleys in old sediments, causing tributary incision and the expansion of the Terra Firme Forest, from higher topography areas, where the biota was already isolated in interfluvial areas separated by the same rivers.

Regarding the Boa Vista Formation, our data reveal a completely different paleogeographic scenario, although with similar deposition ages. The laterites that make up the Boa Vista inferior Formation (FBVI) are the result of the in situ weathering of Precambrian and 
Mesozoic rocks affected by humid and hot climatic conditions. The formation also contains fine-grained quartz deposits and subordinate quartz sandstones, formed by flood-reworked gravitational flow and with intercalated aeolian deposits. There are deposits of small river channels at the base of the unit and associated with an erosion surface, corresponding to the installation of a drainage network after a period of erosion. The paleocurrents in the canal deposits show a north-northeast flow direction, indicating that this network was part of the Proto-Berbice drainage system.

The aeolian deposits correspond to the rework of sediments of the Boa Vista Formation and show a distinct particle size signature, allowing differentiation of these deposits. The OSL dating of the Boa Vista Formation upper unit places the deposit of this unit in the Upper Pleistocene-Upper Holocene and aeolian deposits, such as the Mucajaí dunes, are correlated with other aeolian deposits located in other parts of the Amazon, indicating the correlation of climatic conditions, drier during LGM. It also marks the age of capture and consequent death of the Proto-Berbice River by the Lower Middle Branco River, but this event did not have much effect on the deposition of the Boa Vista Formation, with aeolian and non- aeolian deposition continuing after capture.

Keywords: Solimões, Amazonas, Içá, Branco and Tacutu rivers. Quaternary and facies. Sedimentology. River channels. 


\section{LISTA DE FIGURAS}

Figura 1 - Mapa esquemático das Bacias geológicas amazônicas estudadas

Figura 2 - Descarga média de sedimentos no Solimões-Amazonas e carga de água doce na calha principal do Rio Amazonas

Figura 3 - Mapa geológico da área de estudo e pontos de coleta de amostras 25

Figura 4 - Mapa geológico do estado de Roraima

Figura 5 - Classificação granulométrica indicando o volume de partículas em relação a seu tamanho

Figura 6 - Unidades de terraço Pleistoceno mapeadas separadas por critérios morfológicos

Figura 7 - Exemplos de depósitos de scroll bars em amplos terraços de interflúvios

Figura 8 - Raios e descarga de scroll bars de rios modernos e descarga de paleodrenagens

Figura 9 - Reconstrução de descargas de paleo-drenagens na Amazônia Central

Figura 10 - Exemplos de áreas de vegetação aberta em planície aluvial de avulsão moderna na Amazônia

Figura 11 - Interpretação das feições fisiográficas e bióticas para o período do início do Pleistoceno na Amazônia

Figura 12 - Evolução esquemática dos principais processos de um evento de queda no nível de base no megaleque do baixo rio Juruá

Figura 13 - Síntese dos possíveis parâmetros observados na estratigrafia de terraços

Figura 14 - (A) Arenitos com estratificações cruzadas acanaladas de médio porte (F2).

(B) e (C) Fácies pelitos arenosos com laminação cruzada

Figura 15 - (A) Detalhes dos depósitos de baixa energia. (B) Detalhes do levantamento da coluna estratigráfica ALC 28

Figura 16 - Detalhe das estruturas sedimentares encontradas na seção 56

Figura 17 - Levantamento de coluna estratigráfica ALC 28

Figura 18 - Detalhes da seção do rio Içá (ALC 35)

Figura 19 - Colunas estratigráficas de sedimentos de terraço de Terra Firme relativos aos estágios III e II

Figura 20 - Exemplo de depósitos de planícies de inundação compostos por cunhas de arenitos e pelitos laminados e ocorrência local de lentes de conglomerados de intraclastos e pelitos tabulares 
Figura 21 - Seção colunar do ALC 28

Figura 22 - Exemplo de depósitos de barras fluviais compostos por séries de arenitos com estratificação cruzada e limites inclinados em direção semelhante ao paleofluxo

Figura 23 - Projeções estereográficas das medidas de estratos cruzados e limites de séries e cálculo da orientação da superfície das barras para cada coset ....

Figura 24 - Morfologia de dunas migrando sobre barras e canal secundário próximo à ilha da Xiborena, Baixo Solimões

Figura 25 - Seção colunar ALC 35

Figura 26 - Exemplo de depósitos de barras fluviais compostos por séries de arenitos com estratificação cruzada e limites inclinados em direção semelhante ao paleofluxo

Figura 27 - Imagens de radar de penetração de solo em barra ativa no Baixo Solimões, ilha da Marchantaria

Figura 28 - Levantamento de coluna estratigráfica ALC 35

Figura 29 - Fotos de lâminas dos minerais pesados representativos dos sedimentos dos terraços de Terra Firme (ALC)

Figura 30 - Fotos de lâminas dos minerais pesados representativos dos sedimentos do leito de rios ativos (MAO)

Figura 31 - Localização das amostras utilizadas na análise de proveniência por minerais pesados

Figura 32 - Leques - Distinção entre os sistemas de megaleques do paleo-Madeira e do paleo-Juruá baseada nas assembleias de minerais pesados

Figura 33 - Paleocorrentes

Figura 34 - (A) Afloramento da FBV em área de empréstimo em Malacacheta. (B) Afloramento próximo à margem do rio Tacutu

Figura 35 - Campo das Dunas de Mucajaí 90

Figura 36 - Aspectos da FBV 91

Figura 37 - Curvas de frequência granulometria em 18 amostras da FBVS

Figura 38 - Diagramas de rosas da direção de paleocorrentes em depósitos de paleocanais na base da FBVS

Figura 39 Modelo digital de terreno, com código de cores para Roraima e áreas adjacentes 


\section{LISTA DE QUADROS}

Quadro 1 - Localização dos pontos de coleta das amostras estudadas ........................... 28

Quadro $2-$ Terminologia e intervalos de classes de escala granulométrica ................... 31

Quadro 3 - Relação entre a seleção de grãos e o desvio padrão da análise

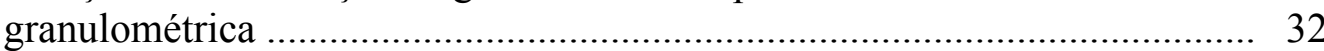

Quadro 4 - Sequência de estabilidade mineralógica ................................................... 34

Quadro 5 - Protocolo SAR aplicado para determinar as doses equivalentes das amostras estudadas ............................................................................. 37

Quadro 6 - Fácies sedimentares, contexto estratigráfico e interpretação ....................... 53

Quadro 7 - Associação entre fácies e elementos arquiteturais dos terraços de Terra

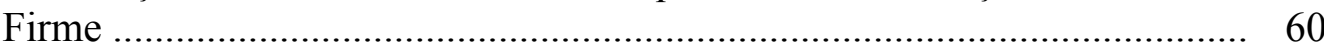

Quadro 8 - Resultado da contagem de grãos de minerais pesados ................................ 70

Quadro 9 - Índices de minerais pesados ................................................................. 71

Quadro 10 - Resultados estatísticos da granulometria das amostras estudadas ................ 80

\section{LISTA DE GRÁFICOS}

Gráfico 1 - Minerais pesados ALC e MAO …......................................................... 75

Gráfico 2 - Assinatura mineralógica das amostras estudadas ..................................... 75

Gráfico 3 - Relação entre a presença de minerais opacos e translúcidos nas amostras estudadas ..................................................................................... 76

Gráfico 4 - Índice ZTR (zircão, turmalina e rutilo) das amostras estudadas .................. 76

Gráfico 5 - Proporção de andaluzita por índice zircão/rutilo em amostras de terraços pleistocênicos e rios ativos

Gráfico 6 - Resultado da análise granulométrica de amostras de sedimentos coletadas em terraços de Terra Firme

Gráfico 7 - Resultado da análise granulométrica de amostras de sedimentos ativos coletadas em leitos de rio (MAO)

Gráfico 8 - Resultado da granulometria de sedimentos dos terraços de Terra Firme (ALC)

Gráfico 9 - Resultado da granulometria de sedimentos do leito dos rios ativos da área de estudo (MAO)

Gráfico 10 - Resultado da granulometria de sedimentos do leito de rios ativos (MAO) .... 83

Gráfico 11 - Curvas de frequência e de frequência cumulativa de granulometria de 18 amostras da FBVS

Gráfico 12 - Correlação entre desvio padrão e diâmetro médio em unidades phi em 18 amostras da FBVS

Gráfico 13 - Histogramas de parâmetros estatísticos e sedimentares de 18 amostras da FBVS

Gráfico 14 - Idade da FBV e de outros depósitos sedimentares na Amazônia 


\section{SUMÁRIO}

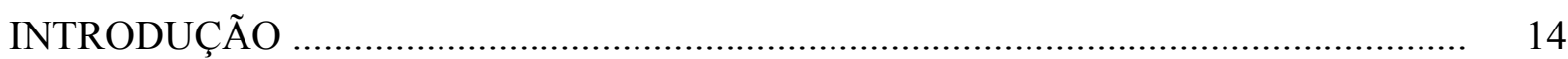

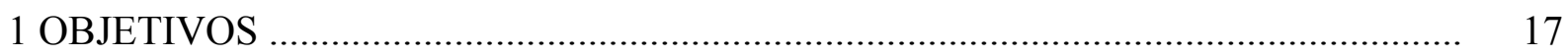

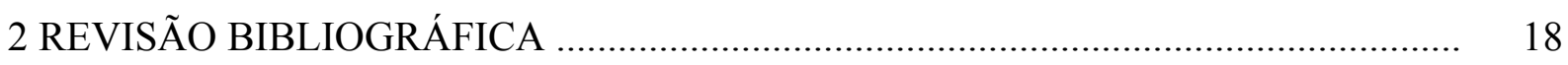

2.1 Contexto geológico regional do Médio Solimões …………………………............ 18

2.2 Contexto geomorfológico regional do Sistema Solimões-Amazonas .......................... 21

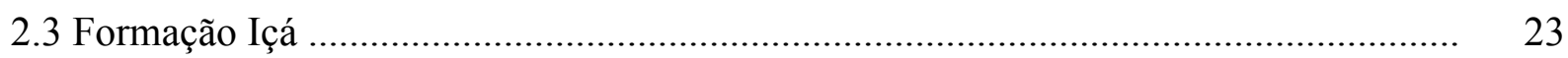

2.4 Sedimentos fluviais ativos ............................................................................. 24

2.5 Geologia regional dos Altos Rios Branco e Essequibo …………………………....... 25

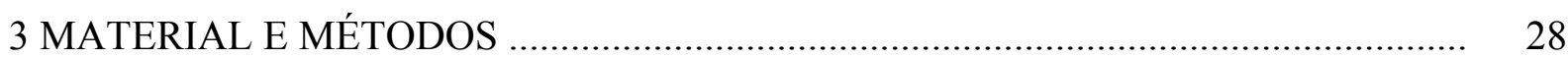

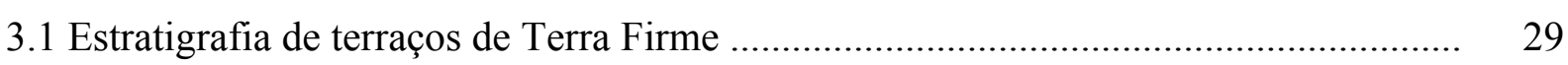

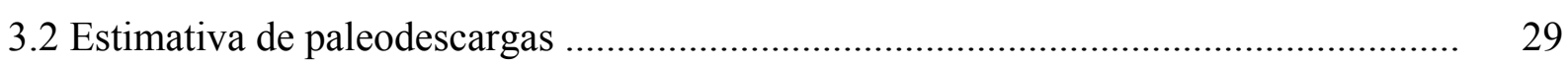

3.3 Modelo numérico dos efeitos eustáticos no nível de base fluvial ............................... 30

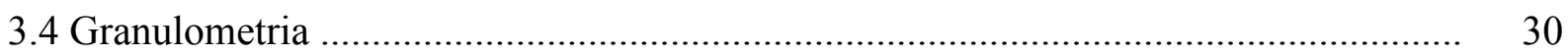

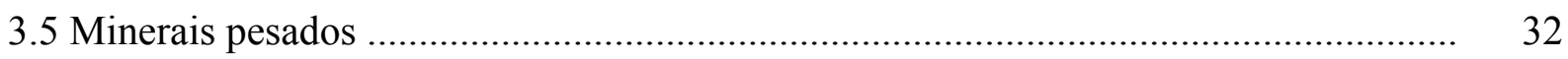

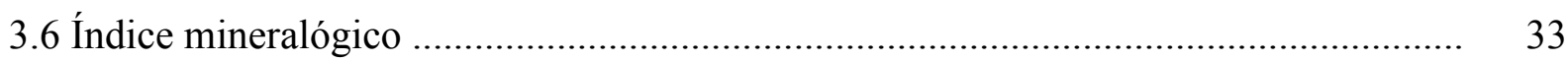

3.7 Análise de fácies e elementos arquiteturais .............................................................. 34

3.8 Luminescência opticamente estimulada (OSL) ............................................................ 35

4 SISTEMAS DE TERRAÇOS PLEISTOCÊNICOS NO CENTRO DA AMAZÔNIA: RECONSTITUIÇÕES PALEOAMBIENTAIS E VARIAÇÕES NO

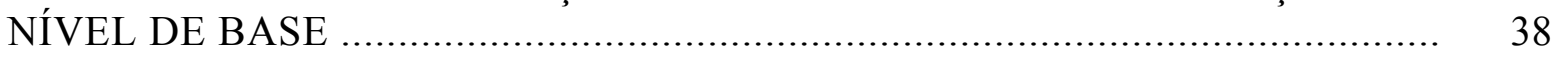

4.1 Estratigrafia de terraços e interpretação das paleobarras fluviais ................................. 38

4.2 Paleodescargas e reconstruções hidrográficas ........................................................... 40

4.3 Dinâmica fluvial e alterações ambientais .................................................................. 44

4.4 Mudança no nível base, captura de rios e evolução de habitats ..................................... 47

5 ANÁLISE DE FÁCIES E ARQUITETURA DOS TERRAÇOS PLEISTOCÊNICOS DA AMAZÔNIA CENTRAL ………………………..................................... 52

5.1 Associação de fácies de planícies de inundação ........................................................... 61

5.2 Associação de fácies de barras fluviais .................................................................... 62

5.3 Associação de fácies de topos de barra e canais secundários .......................................... 66

6 PROVENIÊNCIA E PALEOCORRENTES DOS TERRAÇOS PLEISTOCÊNICOS DA AMAZÔNIA CENTRAL ........................................................................ 70

6.1 Minerais pesados e índices mineralógicos ............................................................ 70

6.2 Interpretação dos dados dos minerais pesados ........................................................ 77

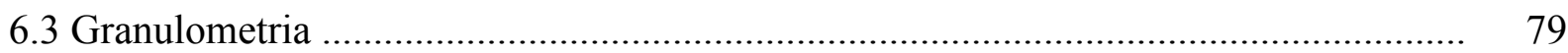




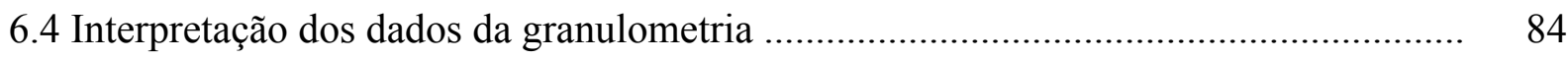

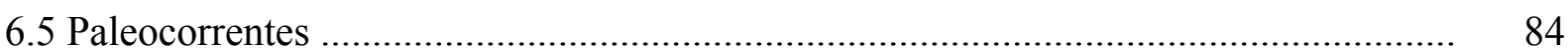

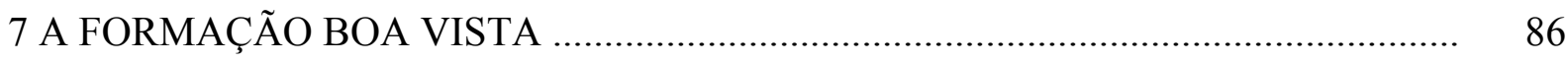

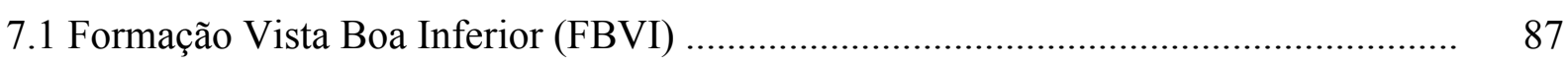

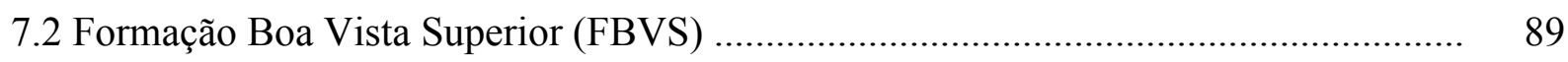

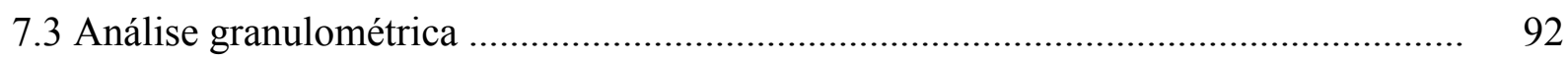

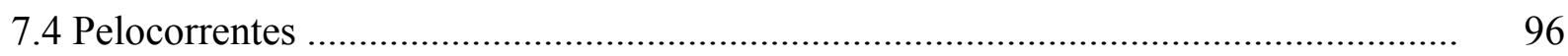

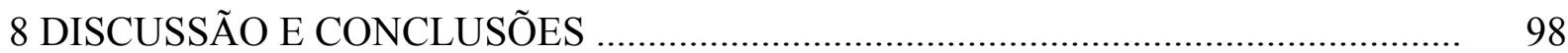

8.1 Terraços pleistocênicos da Amazônia Central .............................................................. 98

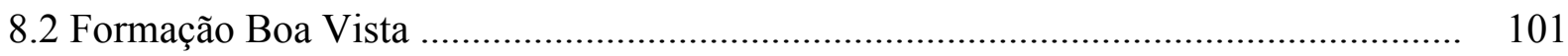

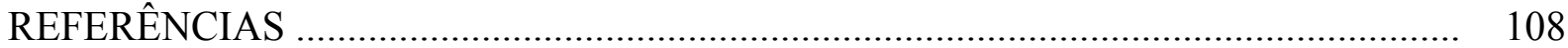




\section{INTRODUÇÃO}

Os grandes rios desempenham papel preponderante na transferência de sedimentos continentais para as bacias oceânicas e por isso são considerados dos mais importantes modeladores do relevo do planeta Terra (Tandon; Sinha, R., 2007). A determinação de "grande rio" para uma drenagem se deve a parâmetros fisiográficos de sua bacia e das drenagens que a compõem, como seu comprimento, volumes de carga sedimentar e de água transportados (Potter, 1978). Ou seja, grandes rios são sistemas hidrológicos com bacias de expressão regional, longos canais principais e grandes descargas de água e sedimento (Tandon; Sinha, R., 2007). Apesar de sua relevância para o registro sedimentar e para reconstituições paleogeográficas, ainda são escassos os modelos conceituais para o reconhecimento de depósitos de grandes rios no registro geológico, restringindo-se basicamente a inferências decorrentes da caracterização morfológica e hidrológica de rios ativos (Miall, 2006; Gupta, 2007; Latrubesse; Wilkinson; Abad, 2014).

A precariedade dos critérios de distinção entre os depósitos de grandes e pequenos rios tem grandes implicações em reconstituições paleogeográficas, e em especial na região Amazônica, onde rios de grande porte atuam como barreiras biogeográficas cuja evolução no Neógeno é fundamental para se compreenderem a distribuição de espécies e a evolução da biodiversidade (Ribas et al., 2011; Ribas; Aleixo, 2019; Pupim et al., 2019). Adicionalmente, modelos paleogeográficos de escala regional a continental dependem em grande parte de documentação concreta da presença, posição e direção dos grandes sistemas de drenagem ao longo da evolução da Amazônia (Rossetti; Toledo; Góes, 2005; Campbell Jr.; Frailey; Romero-Pittman, 2006; Figueiredo et al., 2009; Irion et al., 2009; Hoorn et al., 2010; Irion; Kalliola, 2010; Latrubesse et al., 2010; Wilkinson et al., 2010; Horbe et al., 2013; Nogueira; Silveira; Guimarães, 2013; Rossetti; Zani; Cremon, 2014). Em particular, modelos paleogeográficos que consideram diferentes configurações das grandes bacias de drenagem no passado (Hoorn et al., 2010, 2017; Ribas et al., 2011; Ribas; Aleixo, 2019) têm grande influência na formulação de hipóteses e na interpretação de dados em biologia evolutiva, paleontologia, paleo-oceanografia e paleoclima em escalas regional e continental.

Modelos tradicionais para rios na Amazônia (Latrubesse; Franzinelli, 2002; Rozo; Nogueira; Truckenbrodt, 2012) baseiam-se na descrição de elementos morfológicos a partir de produtos de sensoriamento remoto integrados e na descrição de afloramentos durante o 
período de seca. Apesar da importância dessas observações diretas de produtos sedimentares, as seções colunares representam apenas uma parte do sistema, intrinsecamente sujeita a descargas extremas e variação de estágios. Vários dos grandes rios da Amazônia apresentam canais com profundidade de 15 a 55 metros, mesmo durante o período de seca; assim sendo, estudos baseados em seções de até 15 metros e periodicamente expostas revelam apenas parte dos atuais sistemas de deposição. Canais secundários mais rasos do que os principais são comuns no sistema anabranching (Latrubesse; Franzinelli, 2002; Rozo; Nogueira; Truckenbrodt, 2012), resultando em modelagem mais complexa do sistema com base em depósitos rasos.

Nesse contexto, estudos sobre a forma do leito de rios ativos e a arquitetura deposicional observada em dados geofísicos (Almeida, R. et al., 2016; Tamura et al., 2016; Galeazzi et al., 2018) têm trazido elementos relevantes para aprimorar modelos e determinar critérios de reconhecimento de rios do tipo anastomosado e meandrantes de grande porte, mas permanecem em aberto questões relativas à preservação, no registro sedimentar antigo, dos elementos deposicionais reconhecidos em sistemas ativos. Uma forma de abordar essas questões é o estudo de afloramentos de depósitos quaternários, pois é fácil determinar sua relação com os sistemas ativos em termos de processos e ambientes fisiográficos e, ao mesmo tempo, podem-se aplicar técnicas desenvolvidas para afloramentos antigos, como a análise de fácies e elementos arquitetônicos (Miall, 1996).

Na Amazônia Central, grandes sistemas de terraços, anteriormente mapeados como Formação Içá, registram a deposição, durante o Pleistoceno tardio (Rossetti et al., 2015; Pupim et al., 2019), de sistemas fluviais relacionados aos rios ativos, com exposições em corte nas margens dos principais rios da região. Esses sistemas são um objeto ideal para estudos de arquitetura preservada dos sistemas anabranching de grande porte, pois, quando integrados a estudos de morfologia de estruturas preservadas em planta e análises de proveniência, permitem relacionar diretamente as feições observadas em afloramentos aos sistemas de drenagem ativos na região.

Para a contribuir para o avanço do conhecimento sobre as características de sistemas fluviais de grande porte preservados no registro sedimentar, esta tese discute afloramentos de depósitos pleistocênicos da Amazônia Central e, como contraponto, exposições de depósitos de idade semelhante de sistemas fluviais menores no estado de Roraima. A seção de resultados está estruturada em três artigos a ser publicados. O primeiro aborda a estratigrafia, 
paleocorrentes, paleodescargas e a evolução paleogeográfica dos sistemas de terraços pleistocênicos da Amazônia Central com base no estudo de modelos digitais de terreno e imagens orbitais. O segundo, a sedimentologia e a arquitetura deposicional de exposições de alguns desses terraços como observadas em afloramentos. Adicionalmente, apresentam-se dados sobre a granulometria e as assembleias de minerais pesados que complementam os artigos em preparação. O terceiro trata das exposições de sedimentos pleistocênicos do norte do estado de Roraima e da República Cooperativa da Guiana, mapeados como Formação Boa Vista e correlatos.

O conjunto dos resultados revela que de fato os depósitos pleistocênicos dos grandes rios da Amazônia Central têm características particulares que os distinguem dos modelos de fácies fluviais tradicionais, revelando elementos análogos aos observados ou interpretados em estudos geofísicos nos sistemas ativos. 


\section{OBJETIVOS}

Os objetivos desta tese são:

- Registrar a arquitetura deposicional de depósitos do Pleistoceno tardio expostos em afloramentos dos sistemas de terraços da Amazônia Central e da Formação Boa Vista.

- Obter informações paleoambientais da morfologia preservada nos terraços de modo a correlacionar os depósitos com os sistemas ativos.

- Determinar a proveniência, as paleocorrentes e a variação granulométrica desses depósitos, compondo cenários de fluxo regional de sedimentos. 


\section{REVISÃO BIBLIOGRÁFICA}

\subsection{Contexto geológico regional do Médio Solimões}

A maioria dos grandes rios e seus vales contém registros estratigráficos aluviais que permitem entender seu desenvolvimento em diferentes etapas da escala geológica do tempo. São peças importantes no ciclo hidrológico, e responsáveis por grande aporte de material orgânico e inorgânico que forma e mantém sistemas bióticos inteiros. Economicamente, despontam como importantes locais de depósitos fluviais do Gondwana na mineração de depósitos placers de urânio, ouro e diamante, entre outros minérios, e seus deltas são áreas de fauna e flora abundantes (Tandon; Sinha, R., 2007).

Existem no mundo cerca de 50 grandes rios, responsáveis por $47 \%$ da água continental (incluindo a Groenlândia e a Antártica), destacando-se o Nilo, o Congo e o SolimõesAmazonas, dos quais só o primeiro e o último têm mais de $6.000 \mathrm{~km}$ de comprimento da nascente até a foz. Os rios que apresentam as taxas mais altas de descarga anual de água são o Congo, com $40.000 \mathrm{~m}^{3} / \mathrm{s}$, e o Amazonas, com $200.000 \mathrm{~m}^{3} / \mathrm{s}$ (Hovius, 1998).

A carga de sedimentos do rio Amazonas, medida nas cercanias da cidade de Óbidos, próximo ao ponto máximo de descarga sedimentar no interior do canal do rio, apresentou o valor médio de 1.200 milhões de toneladas por ano, e só dois outros rios no mundo têm tamanhos similares: o Ganga-Brahmaputra (Índia) e o Amarelo (China) (Tandon; Sinha, R., 2007). Ainda não há um consenso sobre os valores de sedimentos em suspensão, que podem variar entre 600 e 800 milhões de toneladas por ano (Filizola; Guyot, 2011).

O Solimões-Amazonas fica na Bacia do Solimões, que tem cerca de $450.000 \mathrm{~km}^{2}$, com orientação regional na direção E-W e está sobre rochas cratônicas pertencentes aos escudos Guianas e Brasileiro. Pode ser dividida em duas partes, a sub-bacia Jandiatuba (oeste) e Juruá (leste), separadas pelo Arco de Purus. A história de sua evolução geológica é marcada por atividades tectônicas relativas à orogenia andina. Nessa enorme bacia, afloram sedimentos pertencentes às formações Solimões e Içá e a depósitos holocênicos (Caputo, 1984; Cordani et al., 1984; Pedreira da Silva et al., 2003; CPRM, 2006; Eiras, 2005). 
Figura 1 - Mapa esquemático das bacias geológicas amazônicas estudadas

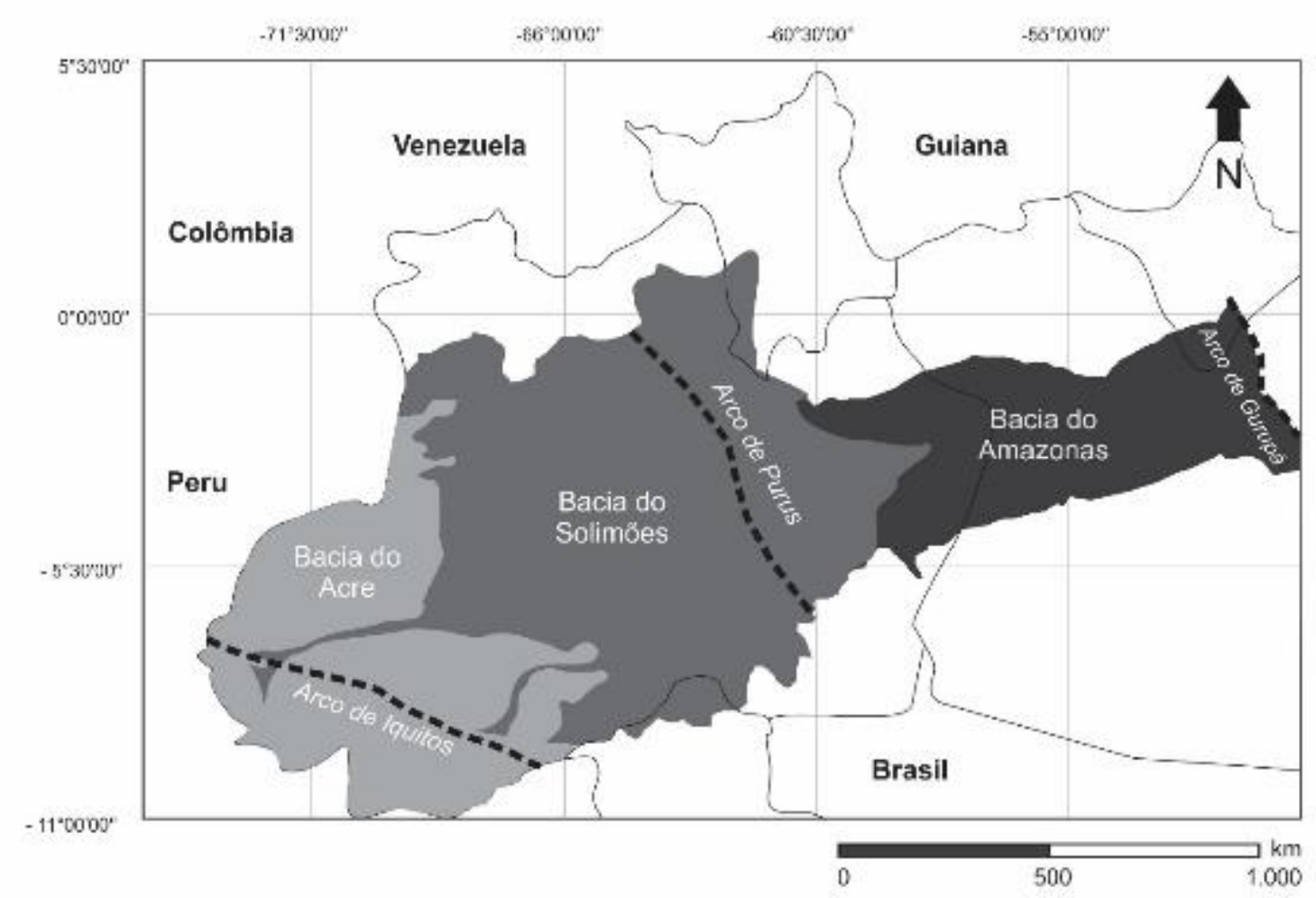

Fonte: Modificado de Eiras (2005) e Souza, E. et al. (2013).

Ocorrido durante o Cenozoico, o soerguimento dos Andes foi possivelmente responsável pela alteração regional da direção das drenagens orientando-as para leste, em direção à baía de Marajó, no estado do Pará, transformando o Solimões-Amazonas num grande rio transcontinental (Hoorn et al., 2010, 2017). A primeira etapa desse fenômeno foi o desenvolvimento desse sistema continental lacustre denominado Pebas (Hoorn et al., 2010) e marca o início da deposição dos sedimentos finos, ricos em fósseis e turfas pertencentes à Formação Solimões (Campbell Jr. et al., 2001; Figueiredo et al., 2009; Campbell Jr., 2010; Hoorn et al., 2010, 2017; Latrubesse et al., 2010; Silva-Caminha; Jamarillo; Absy, 2010).

A presença de depósitos de ambientes marinhos na Formação Solimões não é consensual entre autores como Figueiredo et al. (2009) e Hoorn et al. (2010), que argumentam que os fósseis encontrados na região da Boca do Acre dessa Formação indicam que durante o Paleógeno enormes áreas alagadas, nas partes oeste e noroeste da Amazônia, apresentavam alternância entre ambientes fluviais e marinhos estuarinos. Nogueira, Silveira e Guimarães (2013) acusam a presença de estratificação inclinada heterolítica, tidal bundles, brechas intraformacionais e acamamento wave-flaser-linsen, interpretada como típica de ambiente 
deltaico-lacustre, suprido por canais meandrantes e controlado pelo sistema estrutural do Arco de Purus.

Entretanto, baseados no conteúdo fossilífero, Latrubesse et al. (2010) afirmam que os sedimentos da Formação Solimões não pertencem a ambientes com influência de maré, e sim a ambientes fluviais, e, em estudo palinológico de sedimentos a partir de testemunhos oceânico obtidos no Ceará Rise TMAR, Dobson, Dickens e Rea (1997, 2001) e SilvaCaminha, Jamarillo e Absy (2010) categorizam-na como um ambiente fluvial, sem indícios de existência de depósitos lacustres, estuarinos ou marinhos.

Acima da Formação Solimões, estão depositados os sedimentos arenosos, com abundantes estruturas sedimentares como estratificações cruzadas e rara presença fóssil. Pertencentes à Formação Içá, afloram na porção leste do Médio Solimões. Individualizados por Maia et al. (1977) em seção-tipo nos arredores da cidade de Santo Antônio do Içá, os depósitos distinguem-se dos sedimentos da Formação Solimões por serem francamente arenosos, característicos de um ambiente fluvial meandrante (e/ou anastomosado) de maior energia (Melo; Villas Boas, 1994; Latrubesse et al., 1994; Silveira, 2005; Vega et al., 2007; Motta, 2008; Nogueira; Silveira; Guimarães, 2013; Rossetti; Toledo; Góes, 2005; Rossetti et al., 2015; Horbe et al., 2013, 2014).

A idade dos depósitos da Formação Solimões não é consensual. Latrubesse et al. (2010) sugerem que, durante o Plioceno inferior, o sistema fluvial amazônico integrou-se regionalmente, iniciando o fluxo de água e sedimentos em direção ao oceano Atlântico e adquirindo o formato atual de rede de drenagem, e Campbell Jr. (2010) sugere que o rio Amazonas começou a se formar durante o Plioceno, e não no Mioceno Superior, como afirmam outros autores como Hoorn (1994), Latrubesse et al. (1994), Silveira (2005), Motta (2008), Figueiredo et al. (2009, 2010) e Hoorn et al. (2010). O estudo palinológico de sedimentos na região leste do Arco de Iquitos da Formação Solimões indica uma idade entre o Mioceno superior ao Plioceno inferior, sugerindo que o arco ainda estava ativo durante o acúmulo de sedimentos da formação (Silva-Caminha; Jamarillo; Absy, 2010).

Já o entendimento sobre a idade de deposição dos sedimentos pertencentes à Formação Içá mudou de escala de tempo nos últimos anos. Para autores como Rossetti et al. (2015), Sant'anna et al. (2017) e Pupim et al. (2019), os depósitos arenosos Içá foram datados como pleistocênicos, a partir de técnicas de datação de grãos de quartzo pelo método de 
luminescência oticamente estimulada (OSL), obtendo valores de entre 50 e 150 mil anos. Esses dados alteraram a percepção anterior de ser a porção superior da Formação Solimões e pertencerem a períodos como o Plioceno ou mesmo mais antigos (Melo; Villas Boas, 1994; Latrubesse et al., 1994; Campbell Jr. et al., 2001; Rossetti, 2004, 2015; Rossetti; Toledo; Góes, 2005; Silveira, 2005; Vega et al., 2007; Motta, 2008; Campbell Jr., 2010; Nogueira; Silveira; Guimarães, 2013; Horbe et al., 2013; Prothero et al., 2014).

\subsection{Contexto geomorfológico regional do Sistema Solimões-Amazonas}

Anualmente, o Solimões-Amazonas despeja no oceano Atlântico cerca de $6.000 \mathrm{~km}^{3}$ de água e um bilhão de toneladas ${ }^{3}$ de sedimentos continentais e é responsável pela deposição de cerca de $700.000 \mathrm{~km}^{3}$ de sedimentos continentais em depósitos subaquosos em seu delta (Meade, 1994). Os maiores tributários do sistema fluvial Amazonas-Solimões são os rios Japurá, Juruá, Madeira, Marañon, Napo, Negro-Branco, Purus, Putumayo, Tapajós, Ucayali e Xingu.

O Solimões-Amazonas compreende uma extensa rede de drenagens, armazenando grande parte da carga de sedimentos em suas planícies aluviais e, consequentemente, redução na taxa de sedimentação em sua foz (Tandon; Sinha, R., 2007). A maior parte da água capturada pela rede hidrográfica das principais bacias amazônicas, como a dos rios Solimões, Amazonas, Madeira, Negro e Branco, entre outros, é de origem pluvial. O grande volume de chuva na região alimenta a rede de drenagens, sendo estas responsáveis pelo transporte de sedimentos desde os Andes até sua foz (Tandon; Sinha, R., 2007).

Há no sistema regiões com diferentes taxas de pluviosidade coexistindo na mesma bacia. Assim sendo, drenagens amazônicas estão localizadas em diferentes zonas climáticas, e seu regime de chuvas pode ser bastante distinto em termos de valores pluviométricos, e, em grandes rios como o Amazonas, as flutuações locais do nível d'água podem não coincidir com os padrões anuais de pluviosidade da área correspondente (Irion; Kalliola, 2010). A média do gradiente de declividade do rio Amazonas é de $0,7 \mathrm{~cm} / \mathrm{km}$ nos últimos $700 \mathrm{~km}$ e de $7 \mathrm{~cm} / \mathrm{km}$ na região do Médio Solimões, e a influência da maré sobre o rio é sentida até a cidade de Óbidos, a 1.000 km de sua foz (Irion; Kalliola, 2010). 
Figura 2 - Descarga média de sedimentos no Solimões-Amazonas e carga de água doce na calha principal do rio Amazonas

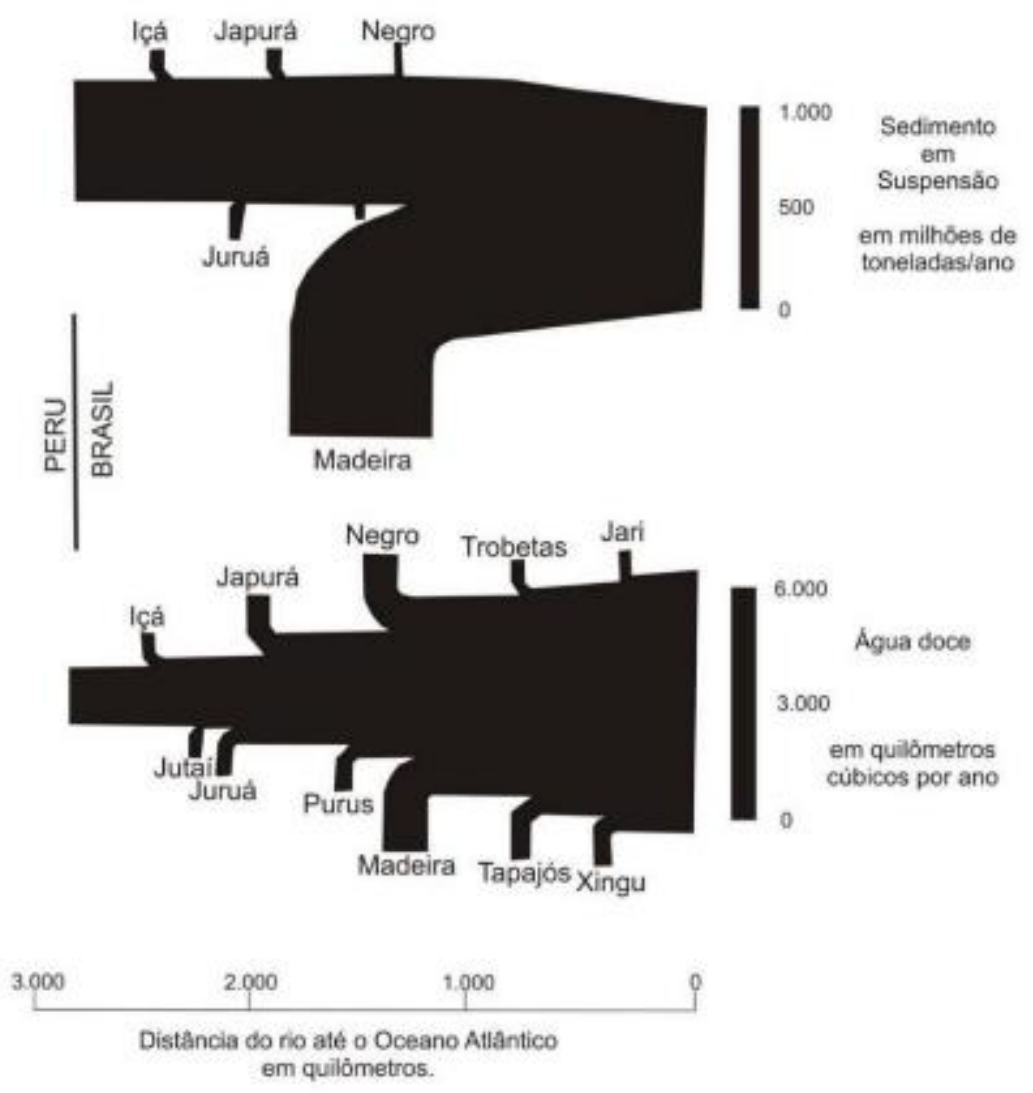

Fonte: Modificado de Meade (2007).

As várzeas do Solimões-Amazonas foram esculpidas devido à oscilação do nível do mar. Normalmente, essa influência só é percebida em áreas litorâneas e adjacências, mas nessa região influenciam grande parte do rio, até quase a metade do continente sul-americano, devido a sua baixa declividade (Irion; Kalliola, 2010).

Para Irion e Kalliola (2010), a oscilação do nível do mar durante o Quaternário confere à sedimentologia um papel importante para se entender o desenvolvimento e a formação do sistema fluvial Solimões-Amazonas. 


\subsection{Formação Içá}

As primeiras descrições dos sedimentos arenosos da Formação Içá foram feitas nos séculos XIX e XX, com distintas denominações, mas foi Gold (1967 apud Maia et al. (1977) quem detalhou e caracterizou os depósitos sedimentares conhecidos com esse nome. Essa formação se caracteriza por sedimentos predominantemente arenosos, repletos de estratificações cruzadas, pouco fossilíferos, com turfas esparsas depositadas em ambiente fluvial e com orientação regional dos paleofluxos no sentido leste (Maia et al., 1977; Vega et al., 2007; Motta, 2008).

A Formação Içá é composta por arenitos com lentes silto-argilosas e apresenta coloração amarelo-avermelhada. Trata-se de sequências psamíticas com pelitos e conglomerados subordinados (Melo; Villas Boas, 1994; Motta, 2008). Sua mineralogia é composta por quartzo, mica, feldspato, fragmentos líticos e minerais opacos (ilmenita e magnetita) (Motta 2008). Trata-se de um quartzo arenito, sub-litarenito, sub-arcóseo, com quartzo angular a sub-angular e arredondado. Os feldspatos são sub-angulosos a subarredondados, e os clastos de rocha ocorrem nas mais variadas formas (Motta, 2008).

Silveira (2005) e Vega et al. (2007) afirmam que as formações Solimões e Içá não fazem parte da mesma sequência estratigráfica. Quanto a sua idade, com base no conteúdo fossilífero e na geocronologia de zircão detrítico $(\mathrm{U}-\mathrm{Pb})$, essas formações foram datadas como sendo plio-pleistocênicas (Latrubesse et al., 1994; Rossetti; Toledo; Góes, 2005; Motta, 2008; Horbe et al., 2013). No entanto, Campbell Jr. et al. (2001), Campbell Jr. (2010) e Prothero et al. (2014) consideram que os depósitos sedimentares das porções superiores da Formación Madre de Dios, na região do rio Putumayo, na Amazônia peruana, e da Formação Içá correspondem ao mesmo depósito, embora separados pela inconformidade de Ucayali. Dados obtidos por Campbell Jr. et al., (2001) e Campbell Jr. (2010) a partir da datação de cinzas vulcânicas pelo método $\mathrm{Ar}^{40} / \mathrm{Ar}^{39}$ revelam idades miocênica superior para a Formação Solimões e plio-pleistocênica para a Formação Içá. Para Nogueira, Silveira e Guimarães (2013), as rochas da Formação Içá começaram a ser depositadas sobre os sedimentos da Formação Solimões durante o Plioceno, mas em tempo e/ou ambientes diferentes.

\footnotetext{
${ }^{1}$ GOLD, O. Pesquisa preliminar de carvão ou linhito na Bacia Terciária do Alto Amazonas. Relatório final. Alemanha, fev. 1967.
} 
A reconstrução ambiental da Formação Içá aponta a existência de um sistema fluvial meandrante com canais ativos e abandonados, interligado por canais secundários cercados por planos de inundação, barras em ponta e diques marginais diretamente relacionados à migração do fluxo do Solimões-Amazonas em direção ao oceano Atlântico (Nogueira; Silveira; Guimarães, 2013; Horbe et al., 2013; Rossetti et al., 2015). Resultados obtidos em datação por luminescência opticamente estimulada (OSL) em sedimentos da Formação Içá apontam o Pleistoceno como o período de deposição, com idades entre 65 e 219,6 mil anos (Pupim et al., 2019). A subsidência e/ou erosão do Arco de Purus teria permitido o desenvolvimento da transcontinentalidade do rio Solimões-Amazonas (Rossetti et al., 2015).

\subsection{Sedimentos fluviais ativos}

A proveniência dos sedimentos da Formação Içá apresenta minerais de características estáveis, sugerindo os Andes como a principal área-fonte, seguido pelo escudo Amazônico, Planalto Brasileiro predominando os minerais ZTR (zircão, turmalina e rutilo). No entanto, Motta (2008) e Horbe et al. (2013) dividem a Formação Içá em duas partes, baseando-se em seu caráter mineralógico, determinado pelo conteúdo de minerais pesados. Na parte inferior, predominariam minerais estáveis e maturo, como a similanita e a andaluzita, enquanto a porção superior seria composição predominantemente minerais como o zircão, a cianita e a silimanita, ultraestáveis e supermaturo.

As características dos sedimentos presentes no leito dos rios ativos erodem os sedimentos da Formação Içá e outros terraços mais jovens e os depositam construindo novas ilhas, barras e cordões de acreção atuais. A proveniência desses sedimentos inconsolidados coletados do leito dos rios Solimões, Amazonas e alguns de seus tributários apontam fontes Andinas como as maiores contribuintes, seguidas pelo escudo Amazônico, pelo Planalto Brasileiro e por sedimentos da Formação Içá e de outros terraços recentes erodidos nas margens dos rios (Figura 3) (Landim et al., 1983; Mapes, 2009; Guyot et al., 2007; Motta, 2008, 2013, 2014; Filizzola; Guyot, 2011).

Destaca-se que, em análises mineralógicas realizadas no rio Amazonas próximo à confluência com o Madeira, também identificado como de fonte andina, os sedimentos encontrados no Baixo Rio Madeira e no rio Aripuanã, pertencentes à Formação Içá, apresentam mineralogia em que predomina a andaluzita, seguida por hornblenda e anfibólios (Rosseto, 2013). 
Figura 3 - Mapa geológico da área de estudo e pontos de coleta de amostras. MAO representam sedimentos de leitos de rios ativos e ALC, afloramentos de terraços de Terra Firme

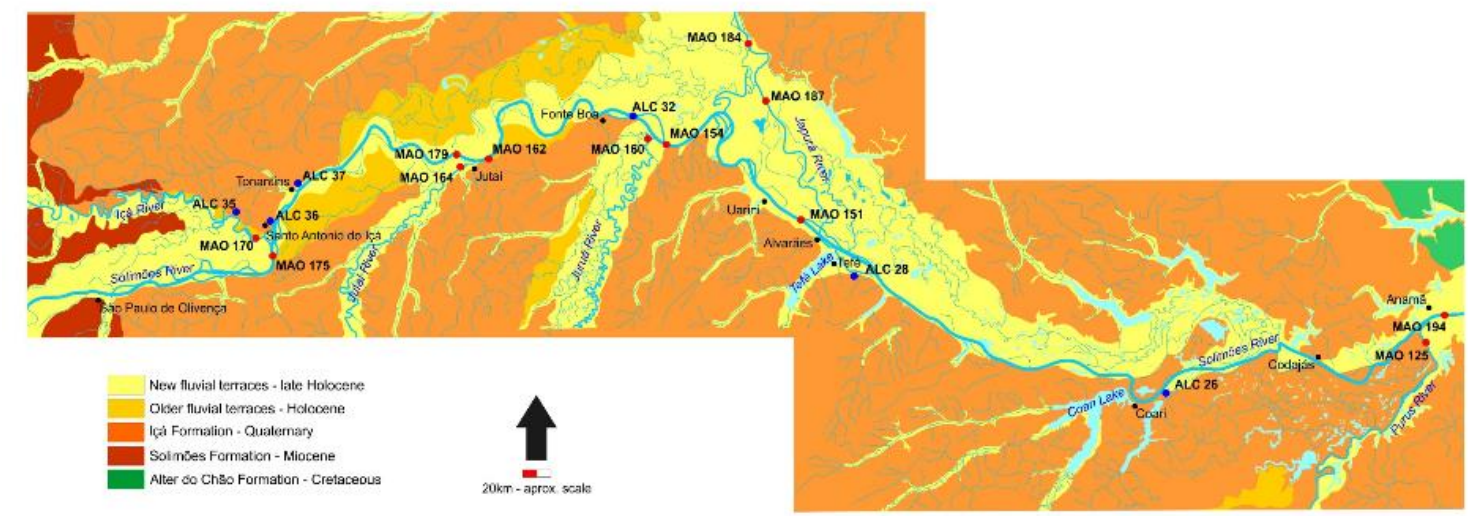

Fonte: Modificado de CPRM (1999).

\subsection{Geologia regional dos Altos Rios Branco e Essequibo}

Os sedimentos da Formação Boa Vista estão assentados em rochas pré-cambrianas do Escudo da Guiana e sedimentos cretáceos e vulcânicas basálticas que formam o Rift do Tacutu, ou a Savana Rift Valley (Figura 4) (Sinha, N., 1968; Berrangé; Dearnley, 1975; Berrangé, 1977; Eiras; Kinoshita, 1990; Zalán, 2004).

O Rift Continental do Tacutu fica na região fronteiriça entre o Brasil (Roraima) e a Guiana (Upper Takutu e Upper Essequibo Provinces), onde se denomina North Savannas Graben, na região central do escudo Guianês. Nas montanhas do Kanuku (Guiana), as rochas pré-cambrianas da borda sul do Rift atingem altitudes superiores a $1.000 \mathrm{~m}$ e, na borda norte, nas montanhas de Pacaraima, as escarpas de falhas têm até $300 \mathrm{~m}$. O Rift tem largura média de 30 a $50 \mathrm{~km}$ e se estende na direção NE-SW por aproximadamente $280 \mathrm{~km}$, da confluência dos rios Rapununi e Essequibo (Guiana) até o Rio Branco (Brasil) (Berangé; Dearnley, 1975; Eiras et al., 1994; Eiras; Kinoshita, 1987; CPRM, 1999; Vaz; Wanderley Filho; Bueno, 2007).

Desenvolvida em região de relevo suave e baixa declividade, indicando alto grau de pediplanização, com altitude média ente 80 e 120 m acima do nível do mar (King, L., 1956; Sinha, N., 1968; McConnell, 1969; Berrangé, 1977; Schaefer; Dalrymple, 1995), apresenta características de planície e dissecação localizada nas drenagens, às vezes intermitentes, ocupadas por veredas (buritizais, Mauritia $s p$ ), lagos e lagoas de diferentes tamanhos. Há morros testemunhos do escudo da Guiana evidenciando contato irregular dos sedimentos com 
o embasamento na região das serras do Murupu, da Moça, do Truaru, do Tabaio, do Tarame, do Meio, da Memória e da Balata, entre outras.

Figura 4 - Mapa geológico do estado de Roraima

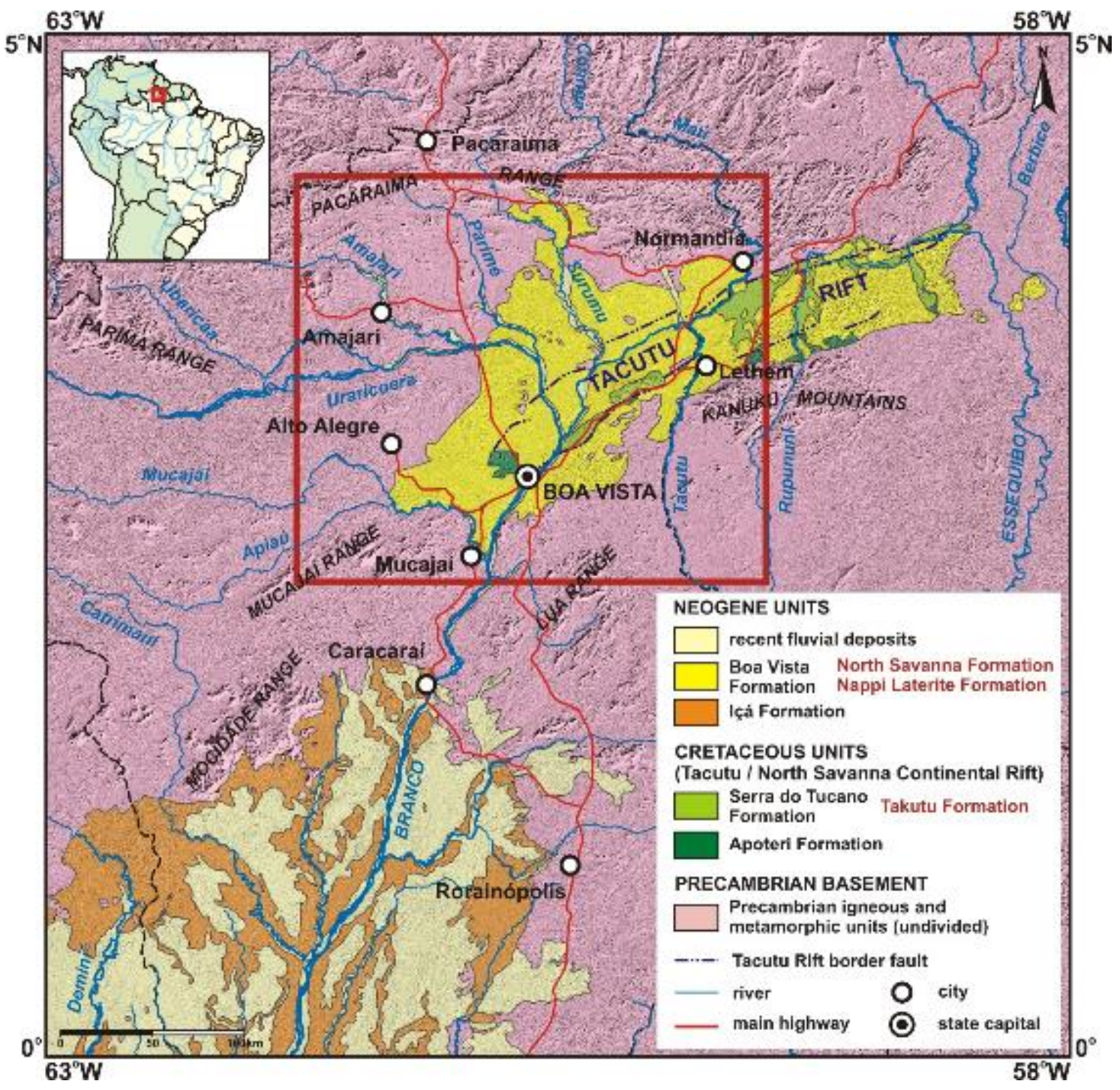

Fonte: Modificado de Radam (1975).

Os correlatos ao Grupo Correntyne mapeados na República da Guiana, onde descrevem as mesmas ocorrências litológicas encontradas em Roraima, são: a Formação Nappi Laterite (equivalente à porção laterítica inferior), a Formação North Savanna (equivalente à seção superior da Formação Boa Vista), a Formação White Sands, de depósitos mais jovens e lagoas, e os depósitos eólicos, denominados White Rivers (McConnell, 1968, 1969; Sinha, N., 1968; Berrangé, 1977). Inicialmente, a Formação Boa Vista foi descrita como sendo composta por depósitos e lentes sedimentares de origem fluvial, e sua base, como espesso e amplo horizonte laterítico ferruginoso, encontrado em mais de uma dezena de 
diferentes formas, ora com espessura decamétrica maciça, ora como depósito de nódulos e concreções de diversos tamanhos (de grânulo a matacão), em constante contato erosivo com a camada delgada (métrica) superficial silto-arenosa ocre, pertencente à porção superior da Formação Boa Vista.

As formas de ocorrência da camada laterítica foram divididas por Guerra (1957) e Sinha, N. (1968) em dez classes, mas, de modo geral, podem ser agrupadas em três tipos principais: pisolítico (pequenos grânulos de laterita em meio à matriz de silte arenoso da porção superior), nodular-conglomerático (nódulos decamétricos sobrepostos sem matriz) e retrabalhado (fragmentos de laterita de diversos tamanhos, de blocos a matacão). Acima desses sedimentos, há depósitos eólicos isolados (paleodunas) e, no topo da coluna, sedimentos de lagos e lagoas (Rice, 1928a, 1928b; Hogarth; Oliveira; Rice, 1928; Ramos, 1956; Guerra, 1957; Barbosa; Ramos, 1959; Sinha, N., 1968; RadamBrasil, 1975; Berrangé, 1977; Schaefer; Dalrymple, 1995; CPRM-PLGB, 1999; Latrubesse; Nelson, 2001; Teeuw; Rhodes, 2004; Meneses, Costa, M.; Costa, J., 2007). 


\section{MATERIAL E MÉTODOS}

Para investigar os objetivos propostos, utilizaram-se diversas técnicas laboratoriais e de campo. Em campo, se analisaram fácies e elementos arquiteturais, mediram-se paleocorrentes e colheram amostras. Foram realizadas duas viagens embarcadas para a área de estudo durante o período de seca. A primeira etapa do campo foi em outubro de 2015 e durou cerca de trinta dias, num percurso da foz do rio Madeira com o rio Amazonas até Manaus; a segunda, em dezembro de 2016, com duração de dez dias e um percurso concentrado nas proximidades da cidade de Tefé, em afloramentos nas margens do Solimões. A área de estudo fica na região do Médio Solimões, entre as cidades de Anamã e Santo Antônio do Içá. Os dados foram obtidos em afloramentos da Formação Içá encontrados nas margens dos rios e em sedimentos dragados de leitos de rios como o Solimões, Içá, Jutaí, Juruá, Japurá e Purus. Nos afloramentos encontrados na Formação Içá, descreveram-se seções colunares com cerca de $20 \mathrm{~m}$ de altura e se observou a presença de estruturas sedimentares em que predominam arenitos com estratificações cruzadas. As análises de dados e laboratoriais foram desenvolvidas nos laboratórios de Bacia Sedimentar e de Sedimentologia e Petrografia Sedimentar do Instituto de Geociências da Universidade de São Paulo (IGc-USP).

Quadro 1 - Localização dos pontos de coleta das amostras estudadas

\begin{tabular}{lcccc}
\hline \multirow{2}{*}{ Amostra } & \multirow{2}{*}{ Local } & \multicolumn{3}{c}{ UTM } \\
\cline { 3 - 5 } & & Zona & E & S \\
\hline ALC 35C & Rio Içá & $19 \mathrm{M}$ & 597589 & 9664345 \\
\hline ALC 36D & Sto. Antonio do Içá & $19 \mathrm{M}$ & 617010 & 9656225 \\
\hline ALC 37C & Tocantins & $19 \mathrm{M}$ & 636890 & 9683855 \\
\hline ALC 28A & Ravina de Tefé & $20 \mathrm{M}$ & 320936 & 9623997 \\
\hline ALC 26D & Coari & $20 \mathrm{M}$ & 489137 & 9548356 \\
\hline MAO 170 & Rio Içá & $19 \mathrm{M}$ & 603655 & 9655658 \\
\hline MAO 175 & Rio Solimões a montante do rio Içá & $19 \mathrm{M}$ & 619296 & 9639890 \\
\hline MAO 162 & Jutaí, no rio Solimões a jusante do rio Jutaí & $19 \mathrm{M}$ & 753644 & 9698464 \\
\hline MAO 164 & Rio Jutaí & $19 \mathrm{M}$ & 731807 & 9687876 \\
\hline MAO 179 & Jutaí, no rio Solimões a montante do rio Jutaí & $19 \mathrm{M}$ & 732840 & 9703618 \\
\hline MAO 154 & Lago Uará, no rio Solimões a jusante do rio Juruá & $20 \mathrm{M}$ & 209712 & 9705058 \\
\hline MAO 160 & Rio Juruá & $20 \mathrm{M}$ & 192835 & 9708515 \\
\hline MAO 151 & Uarini, no rio Solimões a jusante do rio Japurá & $20 \mathrm{M}$ & 280887 & 9659223 \\
\hline MAO 184A & Rio Japurá & $20 \mathrm{M}$ & 255640 & 9765745 \\
\hline MAO 187 & Rio Solimões em confluência com o rio Japurá & $20 \mathrm{M}$ & 270062 & 9724361 \\
\hline MAO 125 & Rio Purus & $20 \mathrm{M}$ & 674483 & 9584075 \\
\hline MAO 194 & Anamã, no rio Solimões a montante do rio Purus & $20 \mathrm{M}$ & 714768 & 9604120 \\
\hline
\end{tabular}

Fonte: Elaborado por André G. Stern. 


\subsection{Estratigrafia de terraços de Terra Firme}

Os terraços fluviais da Amazônia Central foram mapeados e correlacionados com produtos de sensoriamento remoto para interpretar imagens de satélite (Landsat), e o modelo de elevação digital (DEM) deriva da Missão de Topografia do Radar Shuttle (SRTM). Analisou-se a altitude relativa do topo dos terraços em diferentes níveis, ao mesmo tempo em que se observaram suas relações temporais com base em escarpas erosivas que truncam os terraços superiores e limitam os mais baixos e permitem estimar sua cronologia relativa, resultando num modelo com resolução espacial melhor do que a das tentativas anteriores em escala regional (Ruokolainen et al., 2018a, 2018b). As idades dos depósitos estudados foram compiladas a partir da literatura disponível, inclusive idades de luminescência opticamente estimulada em componentes detríticos e idades $C^{14}$ em matéria orgânica.

A descrição sedimentológica e a interpretação dos afloramentos escavados nas margens do Solimões cobriram um trecho de aproximadamente $1.100 \mathrm{~km}$. Os afloramentos estudados são representativos de duas gerações mais jovens de terraços antes do estágio de incisão do vale. A análise de fácies e elementos arquiteturais (Miall, 1996) baseou-se na interpretação de processos e ambientes deposicionais.

\subsection{Estimativa de paleodescargas}

Para estimar a paleodescarga dos rios responsáveis pelos depósitos fluviais de interesse, desenvolveu-se um método baseado na medida do raio de curvatura das scroll bars, permitindo comparar os paleocanais com os rios atuais da região. Selecionaram-se áreas com scroll bars modernas ou muito recentes localizadas em planícies aluviais ativas próximas à estação de medições fluviais para obter dados de descarga dos rios. Para cada scroll bar, colheram-se cinco pontos no Google Earth, com base nas imagens subjacentes do Landsat e nos dados de elevação digital SRTM processados, compondo um único arquivo kml por área. Esses arquivos kml foram processados em código de programação Python elaborado para esse fim, de modo que a cada três pontos adquiridos calculou-se o raio médio de curvatura com base na lei trigonométrica dos cossenos, ou seja, três cálculos por scroll bar representado por cinco pontos. 
Fizeram-se cálculos de regressão separados para modelos considerando rios dos tipos meandrantes e anabranching e tendo em conta que a descarga média obtida nas estações fluviais representa a soma dos canais principais do sistema anabranching e que as scroll bars foram formadas por um deles. De fato, a dispersão relativa à regressão se revelou maior em rios do tipo anabranching, embora ainda seja adequada ao cálculo de paleodescargas.

O mesmo método de medição foi aplicado às barras paleo scroll bars existentes no topo dos terraços mapeados, permitindo calcular as paleodescargas (com erro de dois sigmas derivado da regressão). Comparações com descargas modernas foram feitas localmente, pela medição da área de recarga, a montante das áreas atuais, e das paleo scroll bars, considerando as descargas modernas e as paleodescargas relativas à área de captação a montante.

\subsection{Modelo numérico dos efeitos eustáticos no nível de base fluvial}

O possível sinal da alteração do nível do mar na área foi calculado com o modelo numérico do perfil fluvial com difusão 1D (código Python) considerando uma curva do aumento do nível do mar simplificada para os últimos $430 \mathrm{ka}$ e a variação longitudinal atual da vazão do Amazonas (Paola, 2008). Os parâmetros para o domínio aluvial são os de Paola, Heller e Angevine (1992), considerando um vale com largura de 5 km e diminuição da erosão em 10 vezes embasamento andino.

\subsection{Granulometria}

O estudo granulométrico é uma ferramenta importante para a avaliação quantitativa da porcentagem das diferentes frações do material, ajudando a entender as características texturais que formam o depósito estudado e permitindo distingui-las de outros sedimentos. Dados estatísticos obtidos a partir da análise granulométrica, como desvio padrão, assimetria e curtose apresentados em curvas de frequência, permitem descrever e classificar detalhadamente os sedimentos estudados (Figura 5 e Quadro 2). A análise granulométrica tem grande valia para diferenciar depósitos pertencentes a um mesmo sistema, como se usaram aqui para comparar depósitos fluviais recentes e atuais (Nichols, 2009). 
A seleção dos grãos, ou seja, o desvio padrão das curvas mostra a distribuição do tamanho dos grãos presente em cada amostra, indicando o grau de seleção do depósito. Sedimentos de seleção "boa" têm a maioria dos grãos numa mesma classe granulométrica; os de seleção "pobre" são formados por grãos de diversas classes. A seleção dos sedimentos é um retrato de sua história deposicional diretamente relacionada ao tipo de transporte e energia que atuou nele. Outros parâmetros como a assimetria do histograma indicam a tendência predominante de alguma fração, e a curtose informa se há predominância ou alguma distribuição de alguma fração no depósito estudado (Pettijohn; Potter; Siever, 1973; Nichols, 2009) (Quadro 3).

Quadro 2 - Terminologia e intervalos de classes de escala granulométrica - tamanho dos grãos

\begin{tabular}{cccc}
\hline milímetros $(\mathbf{m m})$ & micrômetros (um) & Phi & classe Wentworth \\
\hline 256,0 a 64,0 & 256.000 a 64.000 & -12 a -8 & matacão \\
\hline 64,0 a 16,0 & 64.000 a 16.000 & -8 a 4,5 & calhau \\
\hline 16,0 a, 0 & 16.000 a 0,0 & $-4,5$ a -2 & seixo \\
\hline 4,0 a 2,0 & 4.000 a 2.000 & -2 a -1 & grânulo \\
\hline 2,0 a 1,0 & 2.000 a 1.000 & -1 a 0 & areia muito grossa \\
\hline 1,0 a 0,5 & 1.000 a 500 & 0 a 1 & areia grossa \\
\hline 0,50 a 0,25 & 500 a 250 & 1 a 2 & areia média \\
\hline 0,25 a 0,125 & 250 a 125 & 2 a 3 & areia fina \\
\hline 0,125 a 0,0625 & 125 a 62,5 & 3 a 4 & areia muito fina \\
\hline 0,0625 a 0,031 & 62,5 a 31,0 & 4 a 5 & silte \\
\hline 0,031 a 0,0039 & 31,0 a 3,9 & 5 a 8 & argila
\end{tabular}

Fonte: Pettijohn, Potter e Siever (1973).

Figura 5 - Classificação granulométrica indicando o volume de partículas em relação a seu tamanho

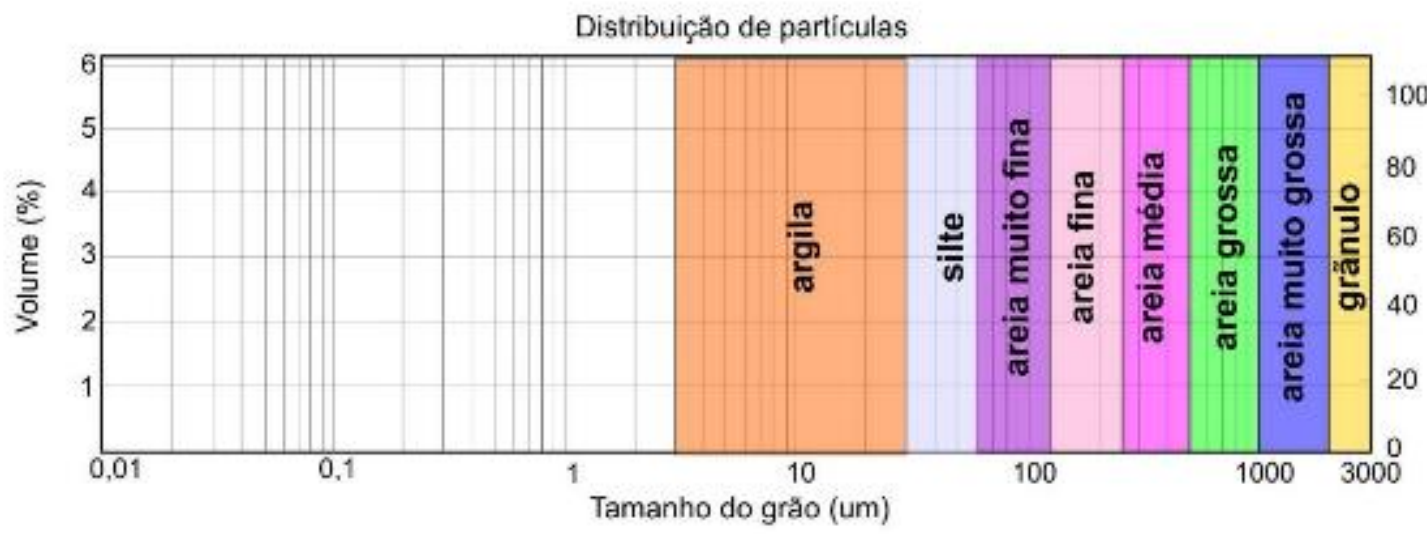

Fonte: Adaptado de Pettijohn, Potter e Siever (1973).

Para verificar a granulometria dos depósitos das áreas de estudo, analisaram-se sedimentos de afloramentos da Formação Içá, sendo 19 amostras entre as cidades de Santo 
Antônio do Içá, Tonantins, Jutaí, Fonte Boa, Tefé e Coari (AM), denominadas ALC, e outras 26 de sedimentos de calha dos rios Solimões, Içá, Jutaí, Jurá, Japurá e Purus, denominadas MAO. Da Formação Boa Vista, colheram-se 38 amostras de sedimentos de sua porção superior.

Esse material foi analisado em granulômetro laser. As amostras foram dissolvidas em meio aquoso e analisadas num equipamento Malvern Mastersizer 2000 com Hydro acoplado. Os dados são apresentados em histogramas, onde se podem ver o diâmetro dos grãos e sua frequência, o diâmetro médio e o desvio padrão, o que permite determinar o tipo de seleção granulométrica do sedimento e a assimetria e curtose, que indicam a tendência da fração do depósito. As análises foram desenvolvidas no Laboratório de Sedimentologia do IGc- USP.

Quadro 3 - Relação entre a seleção de grãos e o desvio padrão da análise granulométrica

\begin{tabular}{cc}
\hline seleção & desvio padrão \\
\hline muito boa & $<0,35$ \\
\hline boa & $=0,35 \sim 0,5$ \\
\hline moderada boa & $=0,5 \sim 0,71$ \\
\hline moderada & $=0,71 \sim 1,0$ \\
\hline pobre & $=1,0 \sim 2,0$ \\
\hline muito pobre & $>2,0$ \\
\hline
\end{tabular}

Fonte: Adaptado de Nichols (2009).

\subsection{Minerais pesados}

A composição mineralógica desses depósitos foi convertida em índices usados para verificar aspectos que permitissem a interpretação geológica de cada depósito, estabelecendo sua assinatura sedimentar (Mange; Maurer, 1992; Morton; Hallsworth, 1999; Weltje; Eynatten, 2004; Viers et al., 2008; Nascimento Jr. et al., 2015).

A determinação da assinatura sedimentar da unidade aflorante permite distinguir depósitos sedimentares, enfrentando a dificuldade de distinguir os sedimentos encontrados nas áreas de estudo. Assim, individualizar parâmetros de área-fonte, granulometria e mineralogia dos sedimentos permite caracterizar a assinatura sedimentar dos depósitos que compõem os sedimentos da Formação Içá e dos leitos de rios ativos da área de estudo. Neste trabalho, colheram-se sete amostras de afloramentos de sedimentos da Formação Içá nas 
proximidades das cidades de Santo Antônio do Içá, Tonantins, Jutaí, Fonte Boa, Tefé e Coari (AM) e 20 amostras para análise laboratorial, sendo 13 de sedimentos de pertencentes à calha dos rios Solimões, Içá, Jutaí, Juruá, Japurá e Purus.

$\mathrm{Na}$ obtenção do concentrado de minerais pesados com densidade igual ou superior a $2,9 \mathrm{~g} / \mathrm{m}^{3}$, observadas as seguintes etapas de preparação laboratorial:

- elutriação: cada amostra foi macerada manualmente em almofariz de cerâmica e pistilo de borracha, para preservar a integridade dos grãos e garantir a retirada do material muito fino;

- peneiramento: as amostras foram secas e peneiradas, para separar a faixa granulométrica de areia muito fina (de 0,125 a $0,062 \mathrm{~mm}$ ); esse intervalo foi escolhido por apresentar a maior probabilidade de concentração de minerais mais densos;

- separação física por densidade dos minerais pesados e leves pela decantação em meio líquido denso (bromofórmio $-\mathrm{CHBr}_{3}$ );

- separação magnética: retirada de minerais ferromagnéticos opacos com imã de mão;

- preparação de lâminas: colagem dos grãos pesados em lâmina com uso de bálsamo do Canadá.

\section{6 Índice mineralógico}

O índice mineralógico é a quantificação da assembleia de minerais pesados realizada em amostras arenosas. As construções dos índices são baseadas em associação de minerais com propriedades físicas ou químicas que possam auxiliar na diferenciação e correlação de depósitos sedimentares.

O procedimento da quantificação dos minerais pesados realizado seguindo o método proposto por Morton e Hallsworth (1999) denominado Ribbon counting ou, contagem em fita. A técnica consiste na determinação, ao acaso, de linhas paralelas que perfaçam a área da lamina. Ao longo destas linhas realizou-se na primeira etapa a contagem de 300 grãos 
considerando somente os opacos e os translúcidos. Na segunda etapa final, foram contados 300 grãos de minerais translúcidos. A fração granulométrica de interesse pertence ao intervalo entre areias muito finas até areias finas (Mange; Maurer, 1992).

A partir do resultado da contagem dos grãos, foram criados índices mineralógicos baseando-se na sua ocorrência e pela persistência ao intemperismo, ou seja, em relação a sua estabilidade mineralógica ao ambiente quente, úmido de alta energia. A ordem geral de estabilidade mineralógica para minerais pesados em arenitos adotados neste trabalho foi balizada pela tabela de sequência de estabilidade publicada por Pettijhon, Potter e Siver (1973), listada a partir do mineral mais instável, a olivina, até o mais estável, o zircão. Neste trabalho, foram adotadas cinco classes de índices principais: ZTR (zircão, turmalina e rutilo) indicando alta estabilidade, APE (apatita e estaurolita) indicando estabilidade, EGKS (epídoto, granada, cianita e silimanita) indicando estabilidade moderada, APA (andaluzita, piroxênios - ferrissilita, diopsidio, augita, aegirina - e anfibólios - hornblenda, actinolita, tremolita) e OL para olivinas indicando altíssima instabilidade (Quadro 4).

Quadro 4 - Sequência de estabilidade mineralógica

\begin{tabular}{ccc}
\hline estabilidade & índice & mineral(is) \\
\hline muito instável & OL & olivina \\
\hline instáveis & APA & andaluzita, piroxênios e anfibólios \\
\hline moderados & EGKS & epídoto, granada, cianita e silimanita \\
\hline estáveis & APE & apatita e estaurolita \\
\hline ultra estáveis & ZTR & zircão, turmalina e rutilo \\
\hline
\end{tabular}

Fonte: Pettijhon, Potter e Siver (1973).

\subsection{Análise de fácies e elementos arquiteturais}

Utiliza-se da análise de fácies sedimentares e de elementos arquiteturais para interpretar depósitos fluviais a partir da descrição de estruturas sedimentares observadas em escala de afloramento. O levantamento de colunas estratigráficas com a identificação e associação das diferentes fácies encontradas procurou reconstruir o processo e o ambiente deposicional. A associação das diferentes fácies encontradas se fez pela descrição de feições deposicionais como textura, estrutura e conteúdo fóssil. Essa associação permitiu interpretar o ambiente deposicional desses depósitos sedimentares (Miall, 1985, 1996, 2000; Nichols, 2009) (Quadro 5). 
Sendo assim, a partir dos dados obtidos com o agrupamento das fácies e caracterização do ambiente deposicional, utiliza-se da análise dos elementos arquiteturais na correlação espacial entre os agrupamentos. O método consiste na descrição sistemática e detalhada de exposições sedimentares buscando a determinação da hierarquia entre as superfícies de estruturas deposicionais e as superfícies limitantes. Na descrição sistemática dos afloramentos utiliza-se da medição de estratificações cruzadas, limites de séries e de superfícies limitantes de tratos sedimentares distintos. As medidas são obtidas, in situ, e indicam as condições hidrodinâmicas quando da sua geração, auxiliando na reconstrução da direção e sentido da corrente (paleofluxo) dos depósitos encontrados.

Para o estudo de paleocorrentes em depósitos aluviais as principais estruturas, indicadoras do sentido de transporte, são estratificações cruzadas tabulares ou acanaladas. A interpretação destas estruturas considera de que o transporte foi paralelo ao maior mergulho do plano frontal para estratificações cruzadas tabulares e tangenciais. E paralelo ao mergulho do eixo de estratificações cruzadas acanaladas. O tratamento de medidas obtidas nos levantamentos das seções colunares e de outros afloramentos encontrados na área de estudo, foram realizados de acordo a métodos propostos por Miall (2000), Potter e Pettijohn (1977), Graham (1988) e Almeida, R. et al. $(2015,2016)$.

\subsection{Luminescência opticamente estimulada (OSL)}

A datação por Luminescência Opticamente Estimulada (OSL) tem como princípio a utilização do fenômeno de luminescência mineral (cavidades do arranjo cristalino), diferente de outras técnicas de datação geológicas mais comuns, que utilizam o princípio do decaimento radiométrico em minerais.

As amostras foram coletadas em tubos de alumínio ou PVC para evitar contato com a luz. A datação por luminescência opticamente estimulada (OSL) foi realizada no Laboratório de Espectrometria Gama e Luminescência (LEGaL) do Instituto de Geociências da Universidade de São Paulo. A preparação das amostras para medidas OSL em alíquotas de quartzo $(180-250 \mu \mathrm{m})$ foi realizada em ambiente sob iluminação controlada (âmbar/laranja) e 
envolveu os seguintes procedimentos: Peneiramento a úmido para separação da fração 180$250 \mu \mathrm{m}$. Ataque com solução de $\mathrm{H}_{2} \mathrm{O}_{2} 29 \%$ para remoção da matéria orgânica. Ataque com $\mathrm{HCl} 3,75 \%$ para a eliminação de carbonatos. Ataque com HF40\% durante 40 minutos para dissolução dos feldspatos e para eliminação da camada externa dos grãos de quartzo. Separação densimétrica de minerais pesados com solução de metatungstato de lítio (densidade de $2,85 \mathrm{~g} / \mathrm{cm}^{3}$ ). Separação densimétrica de feldspatos remanescentes com solução de metatungstato de lítio (densidade de $2,62 \mathrm{~g} / \mathrm{cm}^{3}$ ).

O cálculo da idade OSL envolve a razão entre a dose equivalente (De- Gy), que corresponde à dose de radiação ionizante acumulada desde o último evento de exposição solar, e a taxa de dose (TD) de radiação (Gy/ka) do ambiente de soterramento (Equação 1).

$$
\text { Idade }=\frac{\mathrm{De}(\mathrm{Gy})}{\mathrm{TD}(\mathrm{Gy} / \mathrm{ka})} \quad(\text { Equação } 1)
$$

Para determinar a dose equivalente, aplicou-se o protocolo SAR (Single-Aliquot Regeneration) proposto por Murray e Wintle (2003) (Quadro 5). As medidas OSL foram realizadas em dois leitores Risø OSL/TL reader model DA-20 equipados com LED azuis, filtros Hoya U-340 (transmissão na faixa do UV) e fonte de radiação beta (90Sr/90Y) com taxas de dose de $0,114 \mathrm{~Gy} / \mathrm{s}$ e $0,084 \mathrm{~Gy} / \mathrm{s}$. Curvas de dose-resposta OSL foram obtidas por medidas em alíquotas multigrãos montadas em cups e com o sinal dominado pelo componente rápido $(0,8 \mathrm{~s})$ da dose de interesse corrigido pelo sinal de dose-teste constante. O background foi calculado com os últimos $10 \mathrm{~s}$ da curva de decaimento OSL. O teste de dose (dose recovery test) foi realizado para doses administradas de $50 \mathrm{mGy}, 0,42 \mathrm{~Gy}, 35,7$ e 49,98 Gy. As razões entre doses calculadas e administradas foram respectivamente 1,01, 1,00, 0,98 e 0,97 , em temperatura de preaquecimento de $200{ }^{\circ} \mathrm{C}$. Para determinar as doses equivalentes, aplicou-se o protocolo descrito no Quadro 2.

Em cada amostra, foram medidas 24 alíquotas multigrãos de quartzo, mas só foram consideradas no cálculo da dose equivalente as alíquotas com razão de reciclagem entre 0,9 e 1,1 , recuperação menor que $5 \%$ e sinal de infravermelho insignificante. As doses equivalentes foram calculadas pelo Modelo de Idade Central (Galbraith et al., 1999). 
Quadro 5 - Protocolo SAR aplicado para determinar as doses equivalentes das amostras estudadas. A porcentagem do sinal da D5 em relação ao sinal natural foi usada como medida de recuperação (recuperation test). A reciclagem (recycling ratio) foi medida pela razão entre os sinais das doses D1 e D6. A medida do sinal de D7 foi feita após estímulo com infravermelho a $50{ }^{\circ} \mathrm{C}$. A razão entre os sinais das doses D6 e D7 foi usada para avaliar a contaminação por feldspatos

\begin{tabular}{cc}
\hline \multicolumn{1}{c}{ protocolo SAR } \\
\hline etapa & processo \\
\hline 1 & dose Di \\
\hline 2 & pré-aquecimento a $200{ }^{\circ} \mathrm{C}$ por $10 \mathrm{~s}$ \\
\hline 3 & estimulação com LED azuis a $125^{\circ} \mathrm{C}$ por $40 \mathrm{~s}(\mathrm{Li})$ \\
\hline 4 & dose teste $\mathrm{Dt}$ \\
\hline 5 & pré-aquecimento até $160{ }^{\circ} \mathrm{C}$ \\
\hline 6 & estimulação com LED azuis a $125{ }^{\circ} \mathrm{C}$ por $40 \mathrm{~s}(\mathrm{Ti})$ \\
\hline 7 & iluminação com LED azuis a $280{ }^{\circ} \mathrm{C}$ por $40 \mathrm{~s}$ \\
\hline 8 & repetição dos passos 1 a 7 para Di, i $=0-7$, sendo D0 $=$ sinal natural; \\
& $\mathrm{D} 1<\mathrm{D} 2<\mathrm{D} 3<\mathrm{D} 4 ; \mathrm{D} 5=0 \mathrm{~Gy} ; \mathrm{D} 6=\mathrm{D} 7=\mathrm{D} 1$ \\
\hline
\end{tabular}

Fonte: Galbraith et al. (1999).

A taxa de dose é o resultado da soma da radiação ionizante emitida por radionuclídeos naturais (taxa de dose natural) do ambiente em que o grão ficou soterrado com a radiação cósmica (taxa de dose cósmica). Os radionuclídeos naturais presentes nos minerais são 232Th, 235U, 238U e 40K, além dos filhos do Th e do U. A concentração dos radionuclídeos foi determinada por espectrometria gama de alta resolução em detector de germânio hiperpuro (HPGe, com eficiência relativa de 55\%) em blindagem ultra-low background. Taxas de dose de radiação foram calculadas a partir das concentrações de radionuclídeos, por meio de fatores apresentados em Aitken (1999). A absorção da radiação devido à saturação em água (massa de água/massa da amostra seca) no momento de coleta da amostra foi considerada no cálculo da taxa de dose. A taxa de dose cósmica foi calculada com o software Kosmische, que toma como parâmetros latitude, longitude, altitude e profundidade de coleta da amostra (Prescott; Stephan, 1982).

Com essa técnica, determinou-se a idade dos depósitos sedimentares pertencentes à Formação Boa Vista. 


\section{SISTEMAS DE TERRAÇOS PLEISTOCENICOS NO CENTRO DA AMAZÔNIA: RECONSTITUIÇÃO PALEOAMBIENTAL E VARIAÇÕES NO NÍVEL DE BASE}

Depósitos descritos como Formação Içá podem ser entendidos também como a sucessão sedimentar de terraços quaternários estáveis com altitudes de até dezenas de metros acima dos vales modernos periodicamente inundados e, portanto, abrigando Florestas de Terra Firme. Esses terraços são formados por depósitos sedimentares arenosos que apresentam, em planta, estruturas de grande escala análogas às formadas por barras fluviais em sistemas ativos (Almeida, 1974; Hayakawa; Rosseti; Valeriano, 2010; Wilkinson et al., 2010; Ruokolainen et al., 2018a, 2018b). Morfologicamente, os sistemas de terraços são compostos por uma série de unidades dispostas em degraus com diferentes altitudes, separados por escarpas de 5 a $20 \mathrm{~m}$ de altura com topo plano e mergulho suave em direção ao vale atual do rio Solimões (Figura 1). Relações de corte e diferenças no grau de dissecação por drenagens menores revelam que os terraços mais antigos e mais altos estão preservados a sul, oeste e noroeste da depressão central amazônica, enquanto os mais jovens ocorrem nas proximidades do atual rio Solimões.

Dados geocronológicos revelam que todos os depósitos preservados dentro dos vales modernos na região são mais jovens que aproximadamente $45 \mathrm{ka}$, enquanto as idades disponíveis nos sistemas de terraços de interflúvio, de fato restritas às unidades morfológicas mais jovens, revelam-se maiores que 50 ka (Rossetti et al., 2015; Cremon et al., 2016; Gonçalves Júnior et al., 2016; Sant'Anna et al., 2017; Pupim et al., 2019). As unidades mais antigas, embora não datadas, são provavelmente também de idade pleistocênica, como sugere a boa preservação de estruturas relacionadas por barras fluviais em planta.

\subsection{Estratigrafia de terraços e interpretação das paleobarras fluviais}

$\mathrm{Na}$ área de estudo, podem-se mapear diversas gerações de terraços fluviais, onde os mais velhos e mais altos estão preservados nas margens sul, oeste e noroeste da Bacia do Solimões, sendo os mais novos aqueles próximos ao curso do rio. A sul e sudoeste, os terraços mais velhos fazem limite com depósitos fossilíferos do Mioceno, enquanto em outras áreas eles se sobrepõem (onlap) a unidades geológicas pré-cenozoicas. O mapeamento morfológico permitiu identificar três estágios principais de desenvolvimento do terraço pré- 
holocênico, sendo o estágio I o mais antigo e o estágio III o mais jovem. Os vales modernos cortam esses depósitos pré-holocênicos e também exibem, por dentro, terraços do Holoceno mais jovens (Rossetti et al., 2015; Cremon et al., 2016; Gonçalves Júnior et al., 2016; Sant'Anna et al., 2017; Pupim et al., 2019). Cada um desses estágios pode ser subdividido localmente em unidades menores, não consideradas neste trabalho (Figura 6).

Figura 6 - Unidades de terraço Pleistoceno mapeadas separadas por critérios morfológicos. (A) Localização da região estudada com designações geográficas importantes sobre uma imagem DEM destacando variações nos terrenos aluviais. (B) As três etapas principais da estratigrafia proposta para o terraço. Os números referem-se a unidades de mapeamento individuais, cronologicamente correlacionadas por cores
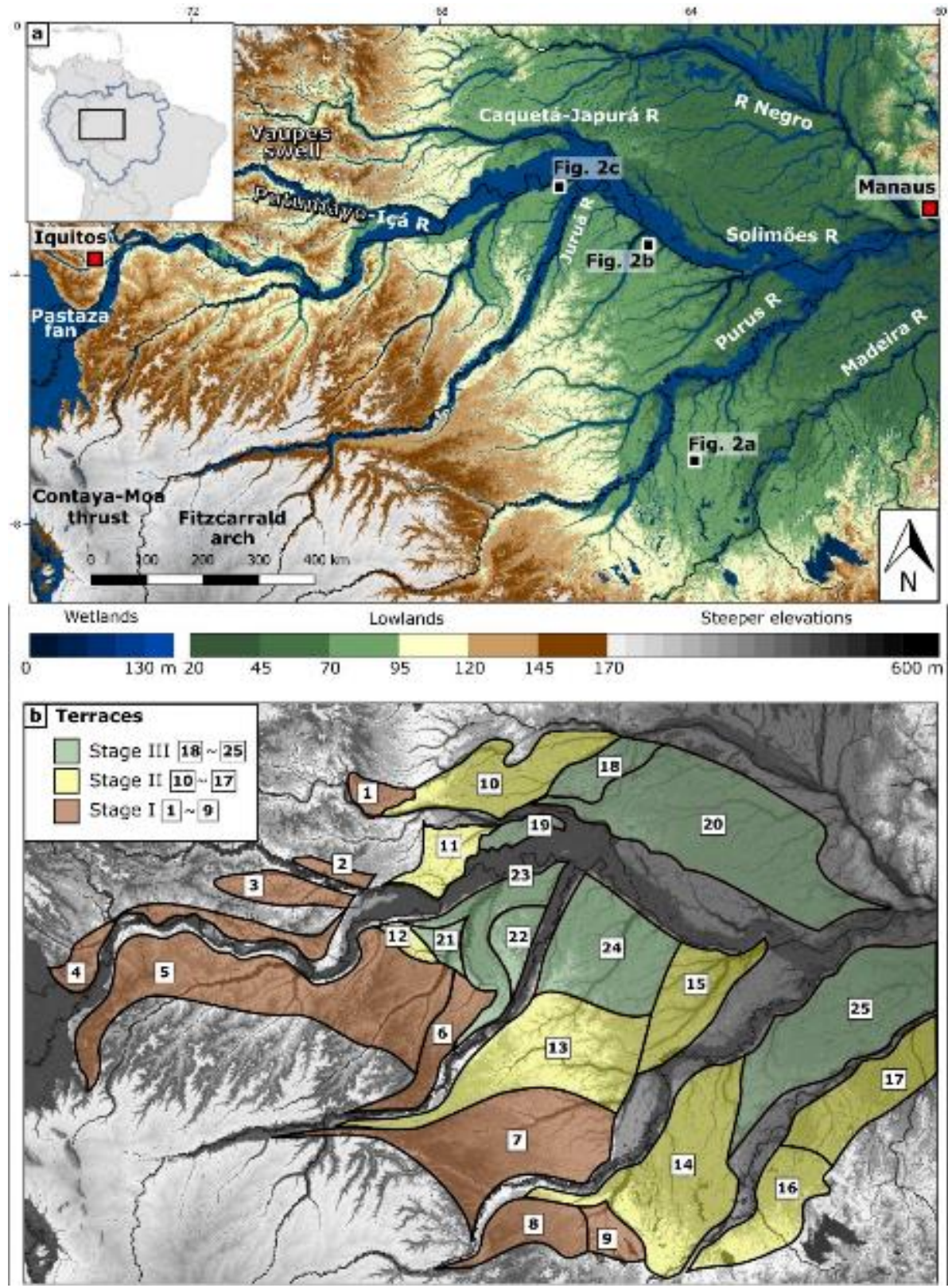

Fonte: Elaborada por André G. Stern. 
Scroll bars são estruturas morfológicas fluviais observadas na Amazônia Central a partir de produtos de sensoriamento remoto como imagens de satélite e modelos digitais de terreno (MDT) em diferentes escalas (Figura 2A), presentes tanto em drenagens modernas quanto nos terraços mais antigos. As scroll bars são produzidas pela migração de canais sinuosos, sendo depositadas na parte interna das curvas de canais, onde a margem externa está sendo erodida, e seu tamanho é indicativo da escala do rio que os formou (Dury, 1976; Williams, 1984). Durante os levantamentos de seções estratigráficas em campo, foi possível observar a exposição interna de alguns terraços pré-holocênicos recém-erodidos ao longo das margens dos rios Solimões e Içá (Figura 7).

Os afloramentos são formados por areias finas a médias e estratificações cruzadas, compondo seções homogêneas com 5 a $25 \mathrm{~m}$ de altura (Figura 7B). Lentes submétricas de argila e silte, geralmente com menos de $25 \mathrm{~cm}$ de espessura e lateralmente contínuas por menos de 100 m, são encontradas principalmente na parte superior das seções, com depósitos espessos de material fino associado a abundantes restos de plantas e camadas de areia fina e silte com estratificações cruzadas localmente expostas (Figura 2C). A interpretação sedimentológica das seções colunares arenosas levantadas está de acordo com o padrão observado em imagem de satélite, revelando os depósitos de barras de areia em rios com 10 a $20 \mathrm{~m}$ de profundidade.

Uma sucessão de depósitos de granulação fina e tamanho métrico está presente na base de diversos afloramentos estudados. Embora anteriormente considerados o equivalente lateral da Formação Solimões de idade do Mioceno, esses depósitos foram datados recentemente por luminescência opticamente estimulada (OSL) e dados de palinologia, o que os revelou mais novos, do Pleistoceno (Pupim et al., 2019). Esses depósitos de materiais finos são provavelmente o registro de um amplo ambiente de várzea, semelhantes aos grandes lagos de várzea que flanqueiam o moderno rio Amazonas a leste da junção com o Rio Negro.

\subsection{Paleodescargas e reconstruções hidrográficas}

Para reconstruir a paisagem do Pleistoceno, é preciso correlacioná-la aos depósitos fluviais modernos, possibilitando inferências sobre a escala e o curso do rio a montante das áreas investigadas. Notam-se tamanhos incompatíveis entre as grandes scroll bars preservadas nos terraços do Pleistoceno e as pequenas scroll bars formadas nos tributários 
modernos (Figura 7A), o que indica que as mais antigas foram formadas por rios muito maiores do que os encontrados atualmente nessas áreas. Pode-se especular que os maiores afluentes do Amazonas antes ocupavam essas áreas de interflúvio em nível mais alto, sendo responsáveis pela maioria dos depósitos, mas é necessária uma abordagem mais quantitativa para determinar a paleogeografia com mais detalhes.

Figura 7 - Exemplos de depósitos de scroll bars em amplos terraços de interflúvios. (A) Mapa digital de terreno (SRTM) exibindo scroll bars do Pleistoceno muito maiores do que as encontradas nos pequenos rios tributários modernos da mesma área, interflúvio Madeira-Purus. (B) Depósitos de barras arenosas do Pleistoceno com estratificações cruzadas expostos na margem do Solimões. (C) Depósitos de planície de inundação do Pleistoceno e barras arenosas expostos na margem do Solimões

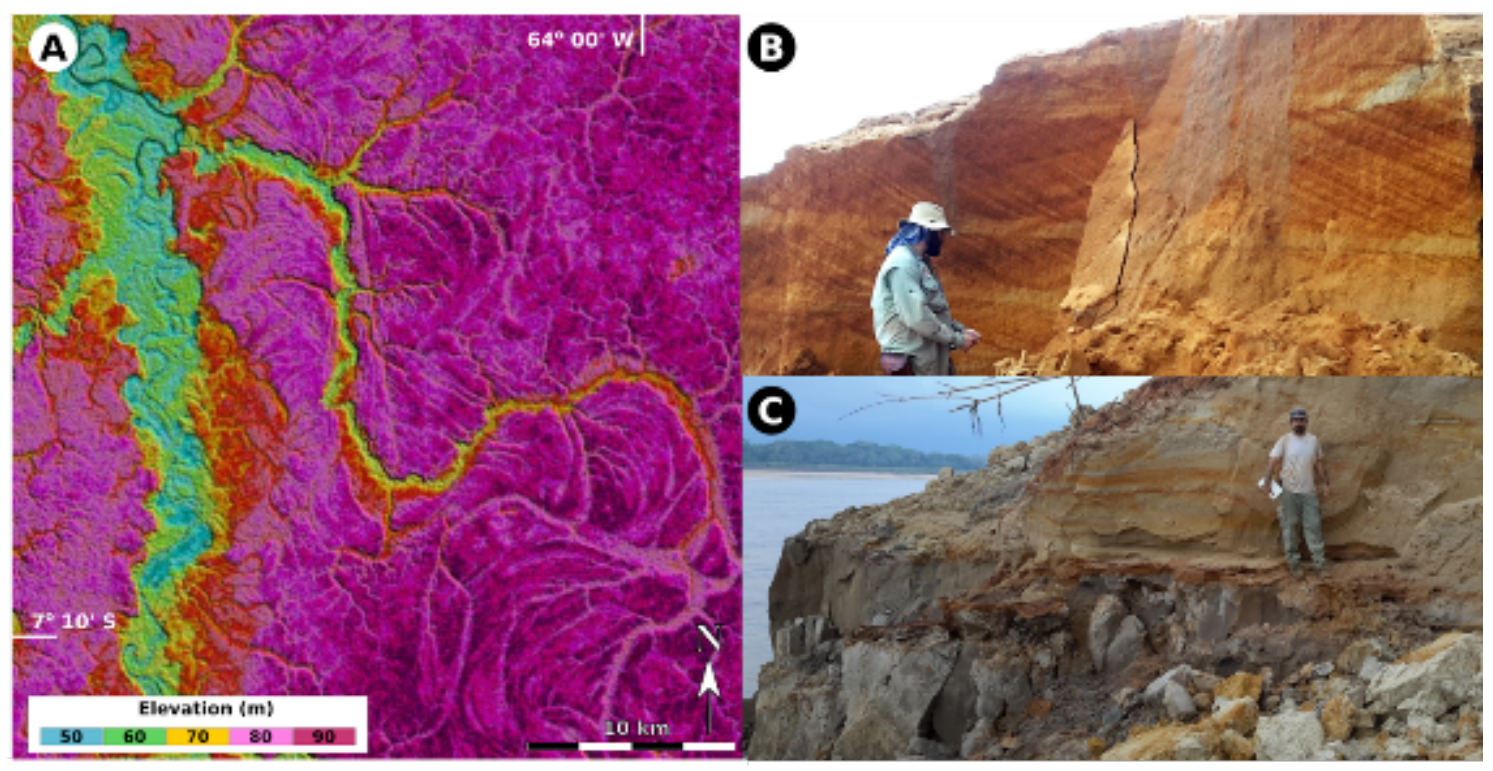

Fonte: Elaborada por André G. Stern.

Uma abordagem possível é o cálculo das paleodescargas dos rios antigos, comparando a escala das scroll bars preservadas nos terraços e a das atuais, presentes nas planícies de inundação dos rios ativos. Métodos publicados para inferir as paleodescargas baseiam-se no raio de curvatura da sinuosidade dos rios, considerando as medidas das curvas de canais nos rios atuais e sua correlação com as descargas modernas (Dury, 1976; Williams, 1984). Uma questão sobre essa abordagem é que a sinuosidade real do canal é uma função dos processos deposicionais que formam as scroll bars e que preservam a curvatura do banco interno e dos processos erosivos que tendem a endireitar o canal e dar origem a curvas maiores (consequentemente, um raio de curvatura maior). No entanto, só os canais abandonados são preservados no registro de rocha. 
Esse processo apresenta um erro no uso da curvatura moderna do canal do rio para inferir a descarga de scroll bars preservadas. Outra fonte de erro seria que diferentes regimes climáticos apresentam diferentes valores de picos de descarga média, e, portanto, as descargas formadoras de canais não podem ser representadas em medidas em décadas. Para minimizar esses erros, optou-se por medir não o raio de curvatura das sinuosidades dos rios ativos, mas o das scroll bars recentes encontradas nas planícies aluviais dos rios modernos da Amazônia, exclusivamente próximos às estações de medição de registro de vazões. Os dados revelaram que, na Amazônia Central, para rios sinuosos e do tipo anabranching, o raio de curvatura da scroll bar é uma boa referência para a vazão (Figura 8), particularmente para a vazão média do período de cheia (três meses) e o pico histórico de descarga.

Figura 8 - Raios e descarga de scroll bars de rios modernos e descarga de paleodrenagens. Superior esquerdo: correlação da descarga média do período de cheia (três meses) com o raio de scroll bars preservadas na planície aluvial adjacente para rios de tamanhos variados da Amazônia, inclusive canais do tipo meandrante e anabranching. Linhas tracejadas são um erro de dois sigmas em relação à regressão. A descarga total mais alta para uma scroll bar de mesmo raio em rios do tipo anabranching do que em rios meandrantes deve-se provavelmente à presença de mais de um canal. Margens inferior e direita: cálculo de paleodescarga e seu erro de dois sigmas para scroll bars preservadas em posições de canais passados em alguns dos principais rios da região, classificadas de acordo com o tipo de terraço e comparadas às dimensões esperadas do sistema moderno em posições semelhantes, definido com base na área de drenagem a montante. Terraços em paleovales referem-se às subdivisões dos terraços do estágio III. Terraços em áreas de interflúvios incluem unidades dos estágios I, II e III

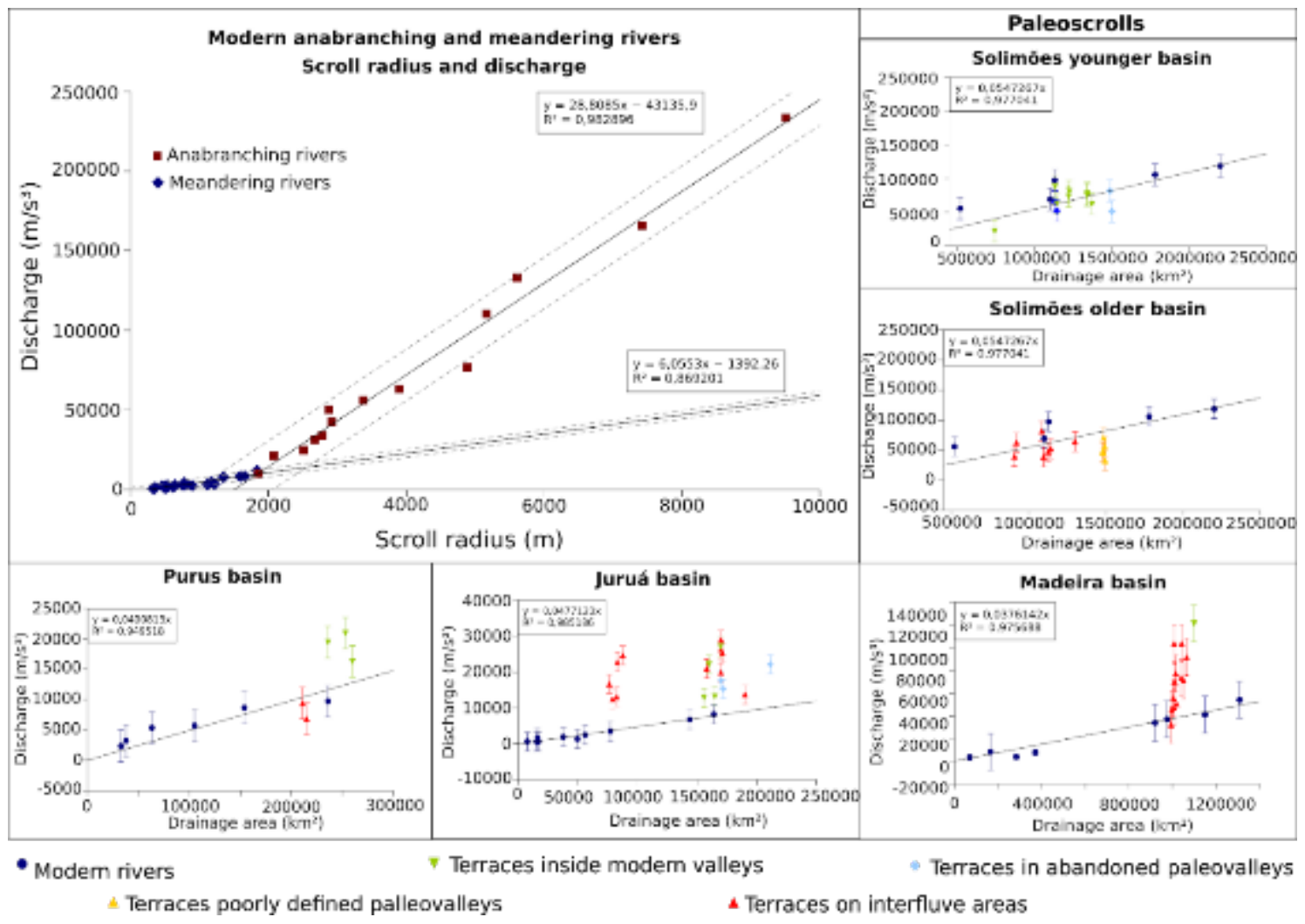

Fonte: Elaborada por André G. Stern. 
É importante notar que as scrolls bars em planícies aluviais recentes também apresentam variação de escala devido a mudanças seculares e milenares na descarga (Strick et al., 2018), mas, como ter ocorrido o mesmo quando as paleo scroll bars estavam sendo depositadas, são igualmente incluídos na dispersão dos dados do raio scroll bar para uma determinada descarga tanto o moderno como o antigo.

Aplicando o modelo de regressão obtido em rios modernos para paleodescargas em scroll bars bem preservadas em coberturas de terraços pré-holocênicos, foi possível comparálos aos rios modernos das mesmas áreas (Figura 8). Os resultados revelam que todos os terraços, independentemente de sua idade, devem resultar da deposição pelos afluentes de primeira ordem do rio Amazonas, como atestam os valores calculados de paleodescarga e os padrões radiais aparentes dos paleocanais que fluem para fora dos vales entrincheirados superiores desses rios modernos (Figura 9). Os terraços ao sul do Solimões, na área de endemismo conhecida como Inambari (Cracraft, 1985), localizada entre o Solimões e o Madeira, estão relacionados às prévias alterações de posição dos rios Juruá e Madeira, com terraços menores atribuíveis aos rios Purus e Ji-Paraná.

Os rios Juruá e Madeira construíram dois megaleques aluviais adjacentes, terminando no Solimões ao norte, cada um avançando passo a passo durante eventos de queda no nível de base e deixando a planície aluvial anterior acima do alcance das águas do estágio de inundação. A paleodescarga calculada em ambos os megaleques é maior que as descargas modernas de ambos os rios. O principal canal do sistema Amazônia-Solimões está relacionado aos terraços pré-holocênicos nas duas margens a oeste da confluência moderna do rio Putumayo-Içá, cujas scroll bars preservadas indicam paleodescargas semelhantes às do Solimões atual. A norte do Solimões, entre ele e o Caquetá-Japuráhá, há outra área de endemismo, denominada Jaú. Essa hipótese implicaria que o Solimões se juntasse ao Rio Negro a centenas de quilômetros a montante do ponto em que o encontra hoje em dia. Terraços pré-holocênicos também foram encontrados nos vales dos rios Putumayo-Içá e dos rios Caquetá-Japurá.

Portanto, terraços em diferentes níveis representam planícies aluviais amplas e diacrônicas que se sucederam devido a mudanças no local de deposição, sendo as mais jovens de menor altitude e mais próximas do eixo principal da bacia de drenagem do que as mais antigas (Figuras 6 e 9). Isso revela uma redução do nível de base durante esse período, com grandes implicações na evolução do cenário físico. 
Figura 9 - Reconstrução de descargas de paleodrenagens na Amazônia Central. As setas apontam na direção do fluxo reconstruída nas estações fluviais. Paleodescargas calculadas com regressão baseada no raio de curvatura do rio moderno da scroll bar e nas descargas modernas de rios da área de estudo, mostradas na Figura 3

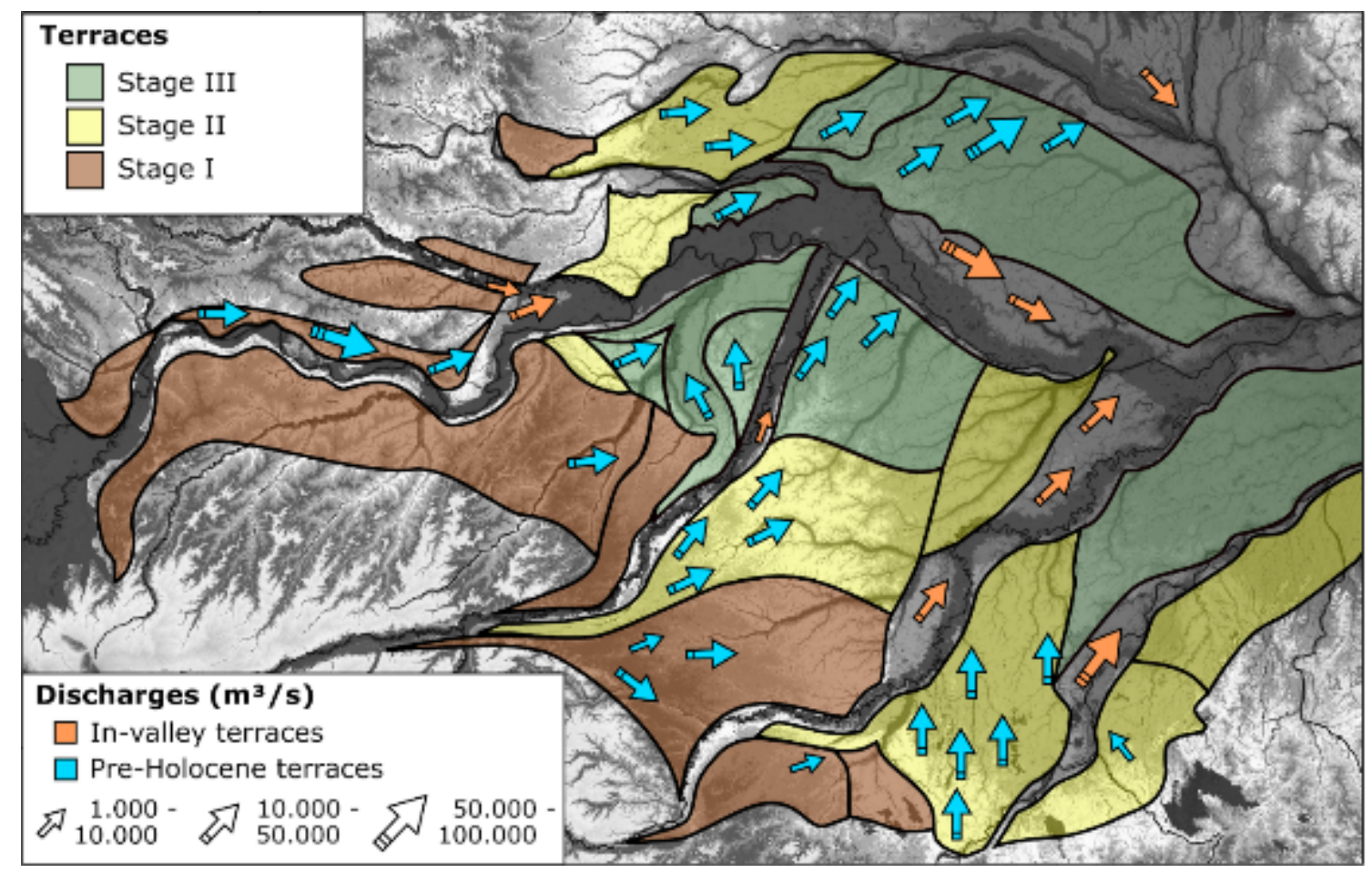

Fonte: Elaborada por André G. Stern.

\subsection{Dinâmica fluvial e alterações ambientais}

Na Amazônia, não apenas os habitats relacionados aos rios e lagos das planícies de inundação são influenciados por processos fluviais, mas também a maioria dos habitats florestais, uma vez que os tipos básicos de floresta são controlados pelo regime de inundação (Floresta de Terra Firme [não pantanosa] versus Florestas de Várzea ou Igapó [sazonal ou periodicamente inundadas]), e a disponibilidade de sedimentos ricos em nutrientes depende da fonte, sendo as várzeas majoritariamente derivadas de planícies de inundação de rios andinos e Igapó em planícies de inundação pobres em nutrientes (Sioli, 1984; (Maia et al., 1977; Nogueira; Silveira; Guimarães, 2013; Rossetti et al., 2015).

As evidências de que os terraços pré-holocênicos da Amazônia foram depositados por canais com avulsões laterais implicam a formação de distintas feições na paisagem por rios modernos confinados em vales erosivos separados por interflúvios ocupados por Floresta de Terra Firme. Grandes áreas de depósitos fluviais, compostas por scroll bars de tamanho e 
elevação similares, formadas por canais divergentes de um ponto nodal de avulsão, são as feições mais comuns em sistemas fluviais modernos (Hartley et al., 2010), formando sistemas fluviais distributivos também denominados leque aluvial ou megaleques (Wilkinson et al., 2010; Latrubesse; Wilkinson; Abad, 2014), onde a mudança de posição dos canais ocorre na escala de cem a dez mil anos. Não estão restritos a áreas próximas aos cinturões de montanhas, como na Amazônia Ocidental, mas são abundantes no caso em que um rio sai de um vale confinado em direção a planícies de baixa declividade. Podem ser considerados análogos a esses sistemas fluviais distributivos o rio Paraná, próximo à confluência com o rio Paraguai na Argentina, o rio Kosi, na Índia, e, na Amazônia, o leque de Pastaza e o rio Ucayali, ao sul de Iquitos (Figura 6).

O lençol freático raso e a baixa topografia desses sistemas implicam áreas amplas semelhantes às florestas inundadas de hoje em dia, como as Florestas de Várzea e Igapó, com abundância de lagos e vegetação aberta. Em lugares dominados por enchentes, a vegetação aberta se desenvolve onde são mais escassos os nutrientes fornecidos pelos rios (longe dos principais rios), independentemente do clima local. Pode-se exemplificar com a avulsão do rio Ucayali, ao sul de Iquitos, onde a subsidência do tipo foreland induz a elevação do nível de base. A grande largura da planície aluvial dificulta o acesso da água da inundação, rica em nutrientes, entre amplas áreas de canais individuais, formando áreas de vegetação aberta, enquanto áreas próximas aos canais exibem Floresta de Várzea (Figura 10). Nessa área análoga ao grande sistema fluvial avulsivo mapeado nos terraços do Pleistoceno, a vegetação aberta é exclusiva onde o vale é mais amplo e não se encontra em dezenas de quilômetros ao norte ou ao sul em vales mais estreitos sujeitos ao mesmo clima.

Mesmo que a drenagem transcontinental amazônica tenha se estabelecido desde o final do Mioceno (Figueiredo et al., 2009; Hoorn et al., 2010, 2017), a grande depressão regional que hoje suporta a Floresta de Terra Firme estava sujeita ao avanço de cunhas de sedimentos fluviais, foi sobre esses depósitos que os principais afluentes do rio Solimões alteraram sua posição dinamicamente em amplas planícies de inundação. Essas planícies receberam sedimentos ricos em nutrientes provenientes dos Andes; diretamente, como os sistemas dos rios Madeira, Japurá e Solimões, ou indiretamente, como os dos rios Juruá e Purus, que drenam unidades com sedimentos andinos (Espurt et al., 2010). 
Figura 10 - Exemplos de áreas de vegetação aberta em planície aluvial de avulsão moderna na Amazônia (rio Ucayali, Peru). A Floresta da Várzea (porção inferior direita) é restrita às áreas próximas aos canais principais, enquanto as formações abertas (à esquerda, na mesma escala) dominam as áreas mais distais

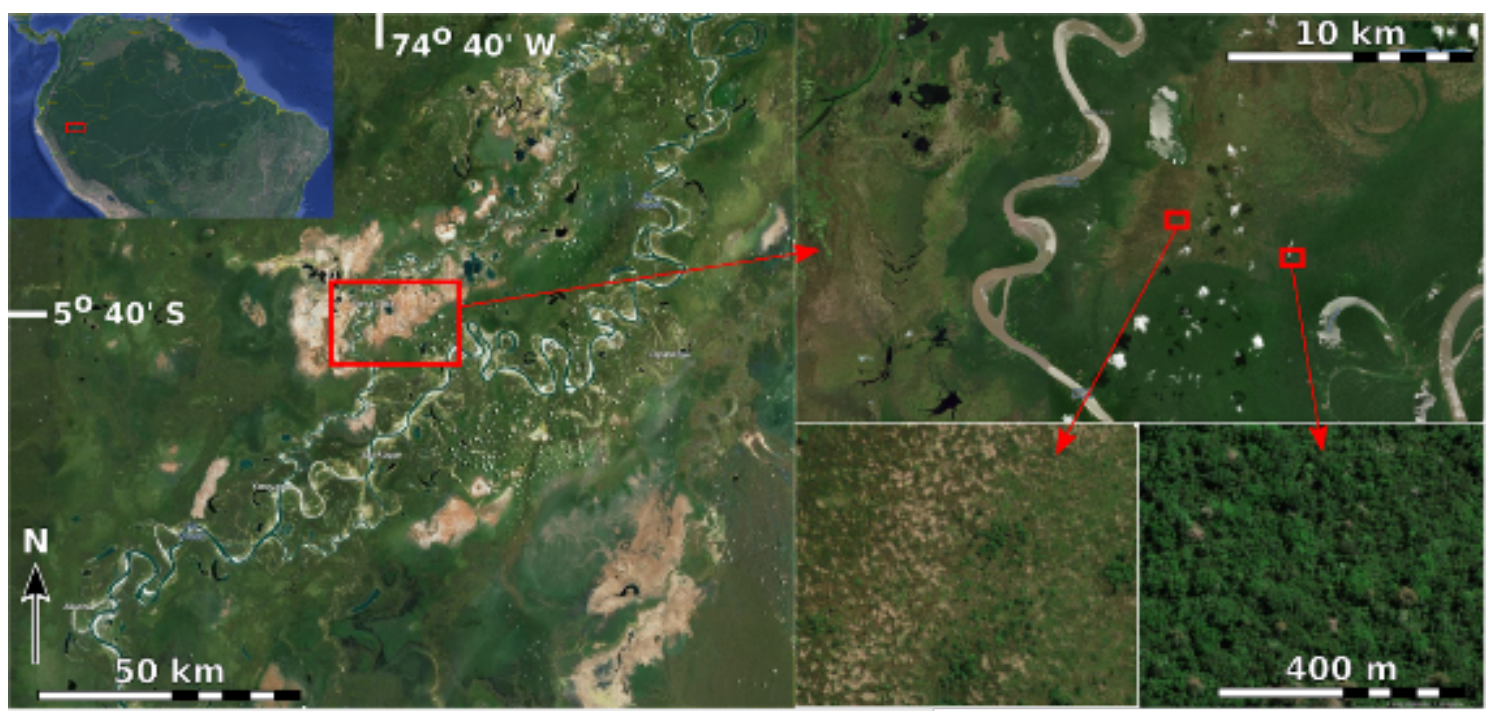

Fonte: Elaborada por André G. Stern.

Frequentes avulsões na posição dos canais principais de drenagens devem alterar o fornecimento de sedimentos finos ricos em nutrientes, normalmente restritos a áreas adjacentes aos canais principais. Comparando-os com os sistemas fluviais distributivos modernos análogos, nota-se que as áreas sem a influência do canal ativo perdem gradualmente a biomassa da floresta, como se pode ver em canais abandonados de vários tamanhos.

Observa-se que áreas distantes da fonte de nutrientes não desenvolvem a Floresta de Várzea, mas são dominadas por ambientes de vegetação aberta. Uma possível causa será o nível subsuperficial do freático existente nessas planícies aluviais ativas, evidenciado pela abundância de lagos nessas áreas, o que provavelmente inibe o desenvolvimento de vegetação não adaptada a solos saturados de água ou em terrenos pouco drenados (Wittmann et al., 2006). Rios instalados sobre o embasamento, incluindo megaleques menores (Rossetti et al., 2012; Rossetti; Zani; Cremon, 2014), provavelmente mantinham a floresta alagada adaptada a níveis tróficos mais baixos (Floresta de Igapó).

Assim, para uma reconstrução paleogeográfica do início do Pleistoceno, seria preciso considerar áreas com amplas planícies aluviais ativas com o mosaico de floresta inundada do tipo várzea em torno dos principais rios com alto nível trófico, grandes manchas de vegetação aberta e lagos frequentes, pelo fato de o nível do freático ser subsuperficial (Figura 11). 
Figura 11 - Interpretação das feições fisiográficas e bióticas do início do Pleistoceno na Amazônia. Porção superior esquerda: interpretação da hierarquia cronológica dos terraços mapeados. Outros quadros: interpretação da evolução paleogeográfica dos habitats em alguns pontos importantes na evolução do terraço e mudanças no nível de base. Abaixo à direita - estágio I: paleogeografia com destaque para os megaleques coalescentes dos rios Juruá e Madeira e a abundância de ambientes aquáticos na planície alagável. Abaixo à esquerda - estágio II: paleogeografia com incisão do leque

anterior do estágio I formando terraços ocupados pela Floresta de Terra Firme e construção de megaleques no nível mais baixo, substituindo parte dos ambientes aquáticos. Acima à direita - incisão pós-estágio III dos vales modernos e avanço total da Floresta de Terra Firme sobre os complexos de

terraços

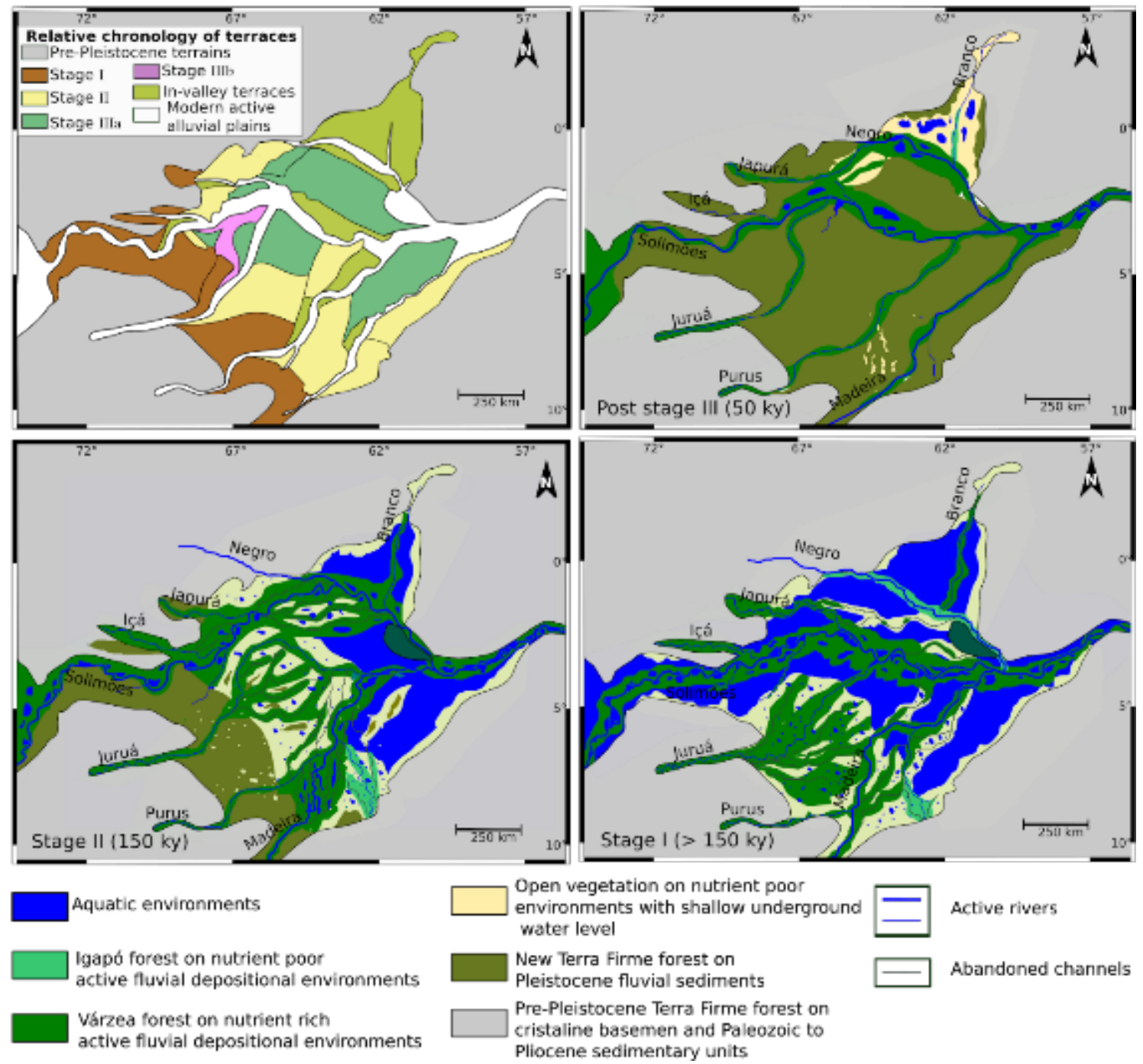

Fonte: Elaborada por André G. Stern.

\subsection{Mudança no nível de base, captura de rios e evolução de habitats}

Desde o estágio I até a morfologia atual, a Amazônia Central experimentou pelo menos quatro ciclos principais de rebaixamento no nível de base e uma consequente formação 
de incisões e terraços (Figura 11). Eventos que se sucedem a cada queda do nível de base são semelhantes. A formação de terraços implica a redução do nível de base a partir de uma deposição e avulsão (Figura 12B), e cada episódio de redução do nível de base leva ao entrincheiramento dos principais afluentes nos vales incisos e a consequente instalação das primeiras ocupações de Floresta de Várzea, fora do alcance das águas da inundação (Figura 12C), enquanto o nível das águas subterrâneas também foi diminuído. Assim, as antigas superfícies deposicionais foram ocupadas pela Floresta de Terra Firme, expandindo-se para terrenos mais altos.

Uma vez rebaixado o nível de base, os rios fluem em vales escavados até atingir áreas não confinadas amplas, onde assumem um padrão distributivo e formam nova cunha sedimentar. $\mathrm{O}$ avanço gradual da cunha de sedimentos fluviais dos rios tributários em direção ao Solimões pode ter substituído ambientes florestais inundados formados por seu eixo ou, provavelmente, por um complexo de várzeas dominado por ambientes aquáticos. As evidências para a segunda hipótese vêm do avanço de sedimentos arenosos das barras e canais dos rios Juruá, Madeira e Japurá sobre ambientes lacustres-fluviais de planícies de inundação (Figuras 7B e 7C). Essa hipótese implica a redução em longo termo dos ambientes aquáticos naquela região, substituídos pela Várzea e posteriormente pela Terra Firme.

O cenário proposto revela um padrão geral de crescimento de Terra Firme na região nas últimas centenas de milhares de anos. Esse crescimento estendeu-se a ambientes aquáticos, mosaicos de florestas inundadas e vegetação aberta, pontuados por breves episódios de substituição de grandes extensões de ambientes aluviais pela Floresta de Terra Firme, expandindo-se a partir de terrenos mais altos.

O processo de substituição de ambientes aluviais e vegetação aberta por Terra Firme envolve a diminuição da altura máxima das inundações (Ferreira-Ferreira et al., 2015) e do nível da água subterrânea, devido à incisão no vale, gerando colmatação dos ambientes florestais inundados. A recuperação gradual da várzea resultaria do alargamento erosivo dos vales situados em posições inferiores. Quando o vale é suficientemente largo para acomodar mudanças na posição do canal e maior que o alcance dos nutrientes das enchentes, começam a se expandir a vegetação aberta e as gramíneas. Assim, cada evento de queda no nível de base, registrado por uma mudança na altura do terraço, causa a redução da várzea e dos ambientes abertos, seguido da recuperação gradual da várzea e, em seguida, das gramíneas. 
Figura 12 - Evolução esquemática dos principais processos de um evento de queda no nível de base no megaleque do Baixo Rio Juruá. (A) Perspectiva atual do megaleque do rio Juruá correndo em direção ao vale entalhado ajustado ao nível da planície aluvial do Solimões atual, na parte norte da imagem. Vista em perspectiva do Juruá atual correndo em direção a um vale rompido do antigo megaleque do Juruá. O nível de base do Juruá moderno está ajustado ao da planície aluvial moderna do Solimões, na parte norte da imagem. Observa-se o entrincheiramento do Jutaí na parte oeste do leque. Elevações cor-de-rosa e mais altas correspondem à Floresta de Terra Firme, enquanto Solimões e arredores correspondem à Floresta de Várzea. (B) Estágio de desenvolvimento do leque (estágio IIIa), dominado pela frequente mudança lateral na posição do canal por avulsão nodal e deposição de sedimentos no canal como elevações aluviais que sustentam a Floresta de Várzea enquanto o canal está ativo. $\mathrm{O}$ alto nível da água subterrânea impede o desenvolvimento de terra firme, levando à ocupação por cerrados, formações abertas e pequenos lagos. (C) Estágio inicial da incisão (IIIb), quando a queda no nível de base entrincheirou o rio Juruá na posição que ocupava no megaleque no início da incisão. O reajuste de todos os afluentes (nem todos representados na figura) para a posição mais baixa do Solimões causando a incisão no vale e o recuo a montante de knickpoint, levando à captura do Juruá para a posição atual. (D) A queda contínua no nível de base evidenciada pela posição alta do vale do paleo rio Juruá, abandonado a oeste, agora parcialmente ocupado pelo Jutaí
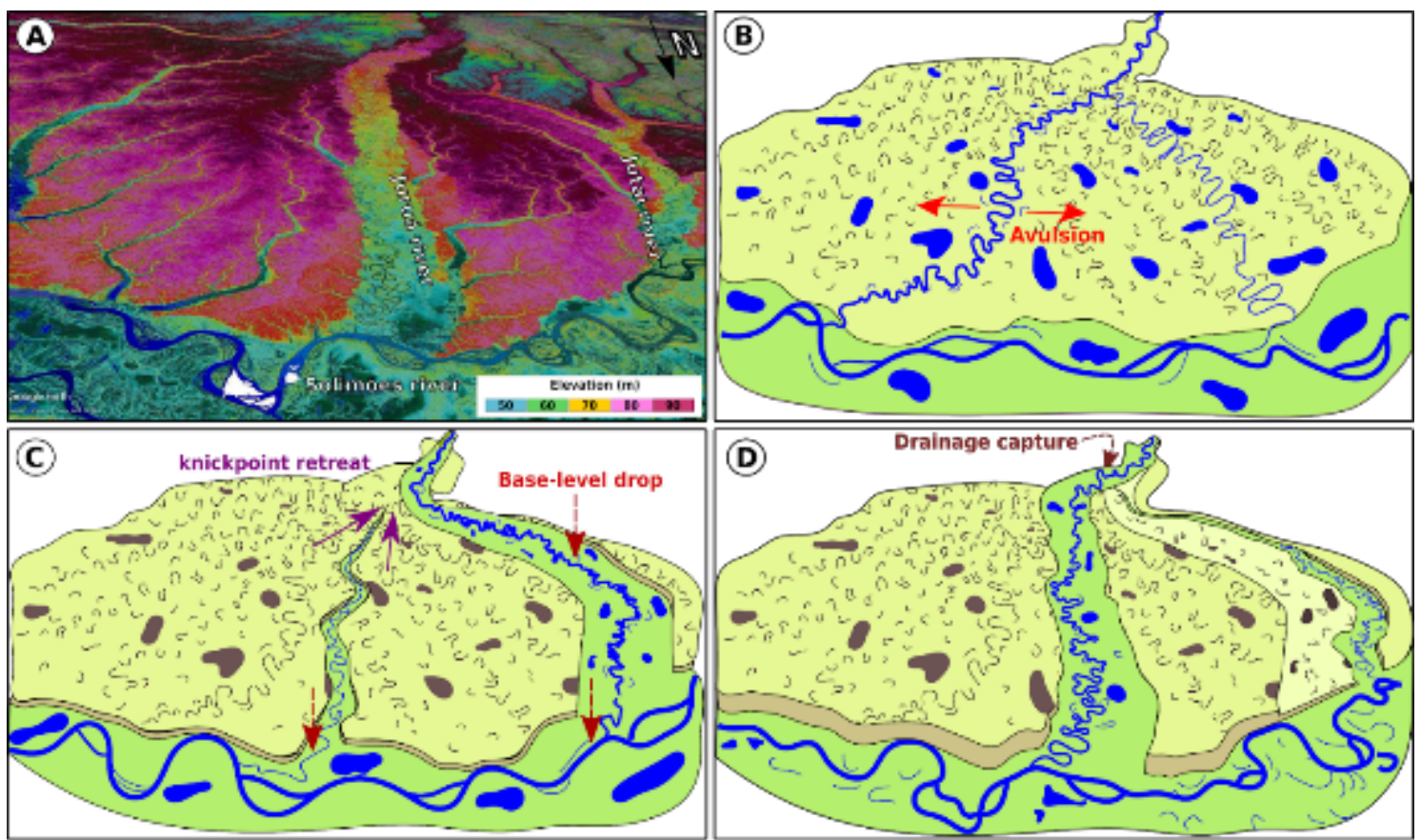

Juruá megafan alluvial plain surface during the accretional-avulsive stage

$\square$ Abandoned Juruá valley from the initial incisional stage $\square$ Solimŏes and low base level tributaries alluvial plains

Fonte: Elaborada por André G. Stern.

Como a incisão decorrente do rebaixamento erosivo do tronco do rio principal atua a partir da jusante dos afluentes e subindo a bacia, durante o período de recuo erosivo do ponto onde há uma mudança acentuada na posição do canal, ou knickpoint, podem-se manter as várzeas a montante ainda sujeitas a inundações sazonais, deixando as faixas mais baixas dos afluentes, já incisos em estreitos vales erosivos, com pouca ou nenhuma várzea. Esse processo causa a interrupção entre as várzeas localizados acima dos tributários, bem como do rio principal, prevalecendo até que o alargamento do vale seja capaz de reconectar esses habitats. 
A dinâmica desses habitats relacionados às áreas alagadas, regulados pela alteração do comportamento dos rios devida a mudanças do nível de base, com distribuição desigual de nutrientes e nível subsuperficial do freático, pode levar a confundi-los com transformações na paisagem induzidas pelo clima, especialmente no caso de cerrados e outros habitats de vegetação aberta. A curta variação do registro de pólen de gramíneas em depósitos sedimentares pode não ter sido necessariamente causada pela expansão do cerrado proveniente do sul, e registros de longa duração devem considerar alterações físicas na paisagem (Hoorn et al., 2017). Assim, o registro da precipitação durante o final do Pleistoceno tardio (Cheng et al., 2013) não está correlacionado às grandes mudanças na vegetação aberta para a floresta e vice-versa, numa escala de dezenas de milhares de anos.

O recuo erosivo dos knickpoints durante um episódio de queda no nível de base afeta todos os afluentes, incluindo os pequenos, que, embora erodindo em ritmo lento, podem capturar o curso inferior de grandes afluentes. Enquanto crescem em direção a montante, seus vales podem encontrar o vale do rio maior, fazendo-o divergir por um caminho mais íngreme (Figuras 12B e 12C). O processo de captura do rio é muito mais rápido em regiões de cobertura sedimentar do que em áreas do embasamento.

Hipóteses anteriores que explicam as profundas erosões nos leitos dos rios Solimões e Amazonas e as origens dos vales permanentemente alagados, localizados nas confluências de alguns de seus tributários, consideram que a diminuição do nível do mar foi causada pela variação do nível de base em razão do Último Máximo Glacial (Irion; Kalliola, 2009). No entanto, deve-se considerar que o ajuste erosivo do leito do rio a uma posição abaixo do nível do mar é alcançado pelo movimento, a montante, da área de maior inclinação longitudinal, sujeita a altas taxas de erosão.

À medida que essas perturbações se movem em direção a montante, perdem amplitude, filtrando apenas as oscilações com alta frequência, e sua velocidade e alcance podem ser calculados numericamente (Paola; Heller; Angevine, 1992; Paola, 2008). Considerando a vazão do rio Amazonas atual e a curva do nível do mar para o final do Quaternário (Waelbroeck et al., 2002), a modelagem numérica revela que, a cerca de 2.000 $\mathrm{km}$ da costa de hoje, as flutuações no nível de base do rio seriam reduzidas a uma amplitude máxima de $40 \mathrm{~m}$, e apenas os principais ciclos seriam reconhecíveis, com tempos de latência de até $9 \mathrm{ka}$, considerando a curva relativa do nível do mar.

A diferença entre as idades disponíveis para os terraços do estágio III e os do estágio I revela que a última queda no nível de base na região ocorreu em torno de 45 ka (Pupim et al., 
2019), não havendo correlação entre esse evento e os efeitos locais da variação no nível do mar (Figura 13). No entanto, esse evento em particular está correlacionado a um período de maior contribuição dos sedimentos clásticos no rio Amazonas para a sedimentação marinha (Govin et al., 2014) e com aumento da precipitação nos Andes (Cheng et al., 2013), sugerindo que a variação da vazão em si poderia ter um papel importante no histórico das incisões (Nie et al., 2018).

As paleodescargas calculadas a partir das scroll bars preservadas revelam uma trajetória de aumento de descarga no Solimões no final do estágio III, o que poderia ter causado uma queda no nível de base. No entanto, é possível considerar que os terraços mais antigos (estágios I e II) foram controlados pelos efeitos continentais de grande amplitude na flutuação do nível do mar antes de $100 \mathrm{ka}$.

Figura 13 - Síntese dos possíveis parâmetros observados na estratigrafia de terraços. Gráfico inferior: variação tardia do nível do mar durante o Quaternário e seu efeito modelado no perfil de base do rio

Solimões-Amazonas em diferentes distâncias da costa (área de interesse representada pelas curvas laranja e vermelha). Curva relativa do nível do mar simplificada de Waelbroeck et al. (2002). Gráfico do meio: porcentagem de sedimentos derivados do rio Amazonas encontrados nos dados GEOB3938-

1 do núcleo offshore (Govin et al., 2014) como representantes da descarga de sedimentos (Qs) e variação correlata da descarga de água na foz do Amazonas. Gráfico superior: estimativas de precipitação relativas, a partir do registro isotópico da caverna andina Cueva del Diamante (Cheng et al., 2013). Barras superiores: faixa de idades disponíveis (Pupim et al., 2019) para terraços em estágio III e terraços atuais, revelando um evento erosivo não correlacionado com a mudança do nível do mar (barra vertical roxa); terraços mais antigos, ainda não datados, podem ter sido depositados entre eventos de queda no nível do mar (barras horizontais marrons)

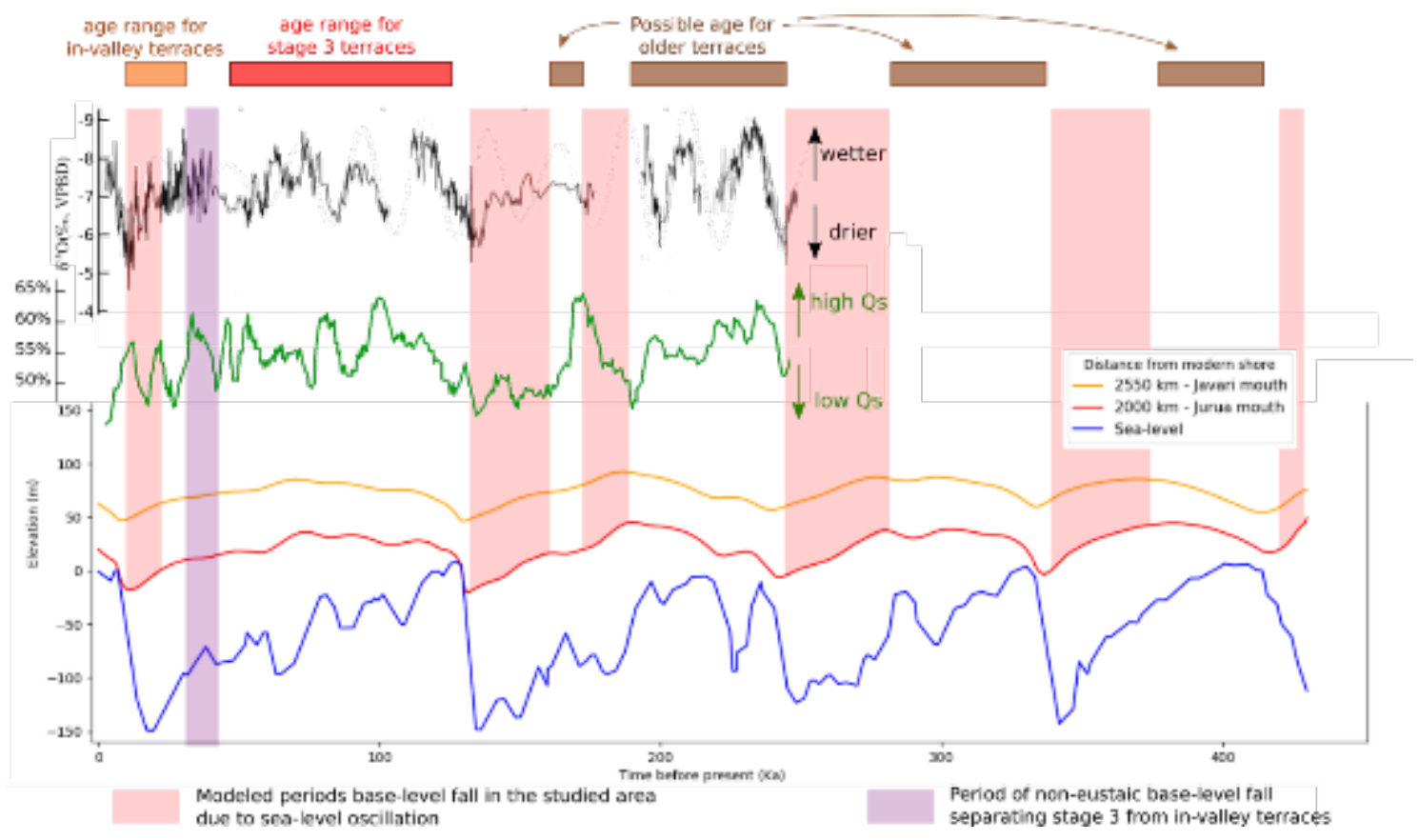

Fonte: Elaborada por André G. Stern. 


\section{ANÁlise de FÁCIES E ARQUITETURA DOS TERRAÇOS PLEISTOCÊNICOS DA AMAZÔNIA CENTRAL}

A análise de fácies e da arquitetura fluvial dos terraços partiu da coleta de dados do levantamento de seções estratigráficas, da interpretação de foto-mosaicos e da medição da atitude de estruturas sedimentares e superfícies limitantes. As principais informações provêm de um conjunto de afloramentos nas margens do rio Solimões entre Coari e Santo Antônio do Içá, onde também se colheu material para análises sedimentares. Os afloramentos ALC 26, nas proximidades da cidade de Coari, e ALC 28, em ravinas nos arredores da cidade de Tefé, apresentam grande exposição de sedimentos pertencentes ao estágio III do sistema de terraços pleistocênicos. Os afloramentos ALC 36, às margens do Solimões nas imediações de Santo Antônio do Içá (AM), e ALC 35, à margem do próprio rio Içá, perto da confluência com o Solimões, referem-se a depósitos mapeados como estágio II do sistema de terraços pleistocênicos. Essas exposições pesquisadas revelam alto grau de preservação de estruturas sedimentares e boas condições para estudos de arquitetura deposicional. Afloramentos com até $20 \mathrm{~m}$ de exposição e continuidade lateral de até alguns quilômetros permitiram levantamentos detalhados e interpretações paleoambientais.

De modo geral, as exposições são muito semelhantes entre si. Trata-se de arenitos médios laranja-avermelhados, marcados por estratificações cruzadas tabulares e acanaladas de médio a grande porte, com lentes argilosas, climbing ripples e depósitos heterolíticos. Evidenciam a ocorrência de diversos eventos deposicionais e erosivos, marcados pelas estruturas sedimentares internas. As exposições investigadas mostram grandes ciclos granodecrescentes (com mais de $20 \mathrm{~m}$ de espessura) em arenitos feldspáticos avermelhados. Esses ciclos começam com arenitos médios a grossos, às vezes ricos em grânulos de quartzo de veio, frequentemente com abundantes intraclastos pelíticos de granulação variada (de grãos de areia grossa a matacões). Na porção basal (com até $5 \mathrm{~m}$ de espessura) são abundantes as estratificações cruzadas tabulares em séries de 15 a $30 \mathrm{~cm}$ de espessura, em arenitos médios a grossos, com ocorrência local de séries isoladas de estratos cruzados acanalados de até $1 \mathrm{~m}$. 
Quadro 6 - Fácies sedimentares, contexto estratigráfico e interpretação

\begin{tabular}{|c|c|c|c|}
\hline $\begin{array}{c}\text { Fácies } \\
\text { sedimentares }\end{array}$ & Descrição & Interpretação & Contexto estratigráfico \\
\hline $\begin{array}{c}\mathrm{F} 1 \text { - areia média } \\
\text { maciça }\end{array}$ & $\begin{array}{c}\text { Areia média e/ou grossa sem } \\
\text { estruturas visíveis. }\end{array}$ & $\begin{array}{l}\text { Depósitos bioturbados e/ou de } \\
\text { transporte por fluxos de massa } \\
\text { em episódios de ressedimentação. }\end{array}$ & $\begin{array}{c}\text { Ocorrência local mais frequente } \\
\text { próximo aos topos das sucessões } \\
\text { de preenchimento de canal. }\end{array}$ \\
\hline $\begin{array}{l}\mathrm{F} 2 \text { - areia média a } \\
\text { fina com cruzadas } \\
\text { acanaladas }\end{array}$ & $\begin{array}{l}\text { Areia média a fina, às vezes com } \\
\text { grãos grossos esparsos, com } \\
\text { estratificação cruzada acanalada em } \\
\text { séries de } 10 \text { a } 40 \mathrm{~cm} \text {. A estratificação } \\
\text { é marcada por variações na } \\
\text { concentração de grãos mais grossos. }\end{array}$ & $\begin{array}{c}\text { Depósitos de migração de dunas } \\
\text { subaquáticas e cristas sinuosas } \\
\text { formadas por correntes } \\
\text { unidirecionais. }\end{array}$ & $\begin{array}{l}\text { Fácies predominantes nos } \\
\text { afloramentos investigados, } \\
\text { ocorrendo em cosets de vários } \\
\text { metros de espessura e compondo } \\
\text { sucessões homogêneas de até } \\
\text { mais de } 10 \text { metros, abaixo de } \\
\text { sucessões contendo F4. }\end{array}$ \\
\hline $\begin{array}{l}\text { F3 - areia média a } \\
\text { fina com cruzadas } \\
\text { tabulares }\end{array}$ & $\begin{array}{l}\text { Areia média a fina, com estratificação } \\
\text { cruzada tabular em séries de } 10 \text { a } 40 \\
\text { cm. A estratificação é definida por } \\
\text { alternância de estratos grossos e finos } \\
\text { com espessura de milímetros a } \\
\text { centímetros. }\end{array}$ & $\begin{array}{c}\text { Depósitos de migração de dunas } \\
\text { subaquáticas e cristas retas } \\
\text { formadas por correntes } \\
\text { unidirecionais. }\end{array}$ & $\begin{array}{l}\text { Fácies de ocorrência local, em } \\
\text { associações dominadas por } \\
\text { cosets de F3 ou em sucessões } \\
\text { com ocorrência local de F5. }\end{array}$ \\
\hline $\begin{array}{l}\text { F4 - areia fina a } \\
\text { média com } \\
\text { estratificação } \\
\text { cruzada tabular de } \\
\text { grande porte }\end{array}$ & $\begin{array}{l}\text { Areia fina a média com estratificação } \\
\text { cruzada tabular de } 60 \mathrm{~cm} \text { a } 4 \mathrm{~m} \text { de } \\
\text { espessura, tangencial na base, } \\
\text { recobrindo níveis pelíticos e/ou ricos } \\
\text { em intraclastos. }\end{array}$ & $\begin{array}{c}\text { Depósitos de avalanche em } \\
\text { laterais íngremes das porções } \\
\text { superiores de barras unitárias } \\
\text { (Tamura et al., 2019). A transição } \\
\text { para fácies finas na porção distal } \\
\text { (inferior) dos estratos cruzados } \\
\text { sugere migração e crescimento na } \\
\text { direção de áreas protegidas do } \\
\text { fluxo. }\end{array}$ & $\begin{array}{l}\text { Ocorrência local mais frequente } \\
\text { próximo aos topos das sucessões } \\
\text { de preenchimento de canal, mas } \\
\text { também diretamente sobre } \\
\text { sucessões finas dominadas por } \\
\text { F7, F6 e F5. Às vezes passam } \\
\text { lateralmente para F5 e finalmente } \\
\text { F7 em direção ao coset das } \\
\text { estratificações cruzadas. }\end{array}$ \\
\hline $\begin{array}{l}\text { F5 - arenitos e } \\
\text { pelitos com } \\
\text { laminação cruzada }\end{array}$ & $\begin{array}{l}\text { Arenitos finos, siltitos e depósitos } \\
\text { heterolíticos com laminação cruzada } \\
\text { cavalgante e marcas onduladas. } \\
\text { Ocorrem em séries de poucos } \\
\text { centímetros a alguns decímetros, com } \\
\text { transições verticais e laterais entre } \\
\text { cavalgamento a ângulos maiores e } \\
\text { menores que o ângulo crítico de } \\
\text { preservação do stoss side. Em alguns } \\
\text { casos, as séries têm inclinação } \\
\text { marcante e empilham-se em sucessões } \\
\text { métricas com geometria em cunha ou } \\
\text { sigmoidal. }\end{array}$ & $\begin{array}{l}\text { Migração de ripples em } \\
\text { ambientes dominados por } \\
\text { desaceleração de fluxo em áreas } \\
\text { protegidas do canal ou ambientes } \\
\text { restritos. A presença de } \\
\text { laminação cruzada em depósitos } \\
\text { sílticos e argilosos sugere } \\
\text { transporte de material floculado } \\
\text { em granulações maiores. }\end{array}$ & $\begin{array}{l}\text { Estratos basais da fácies F4 e } \\
\text { intercalações em sucessões } \\
\text { dominadas por F7 e F6. }\end{array}$ \\
\hline $\begin{array}{l}\text { F6 - conglomerado } \\
\text { de intraclastos } \\
\text { pelíticos }\end{array}$ & $\begin{array}{l}\text { Conglomerados e arenitos ricos em } \\
\text { clastos de argila maciça, variando de } \\
\text { pequenos seixos a calhaus, em geral } \\
\text { subarredondados. Os clastos são } \\
\text { predominantemente imbricados, e é } \\
\text { comum a presença de estratificação } \\
\text { cruzada acanalada ou tabular sobre } \\
\text { limites de série inferiores erosivos. }\end{array}$ & $\begin{array}{l}\text { Depósitos de retrabalhamento da } \\
\text { fácies F7 por correntes em } \\
\text { talvegues de canais principais, } \\
\text { canais de topo de barra e canais } \\
\text { de planície de inundação. }\end{array}$ & $\begin{array}{l}\text { Abundantes em sucessões } \\
\text { dominadas por F7 e F5 e } \\
\text { localmente nos cosets de F4 na } \\
\text { forma de arenitos ricos em } \\
\text { intraclastos nos cosets de F4. }\end{array}$ \\
\hline F7 - argila maciça & $\begin{array}{l}\text { Argilas cinza-esverdeadas, sem } \\
\text { estruturas aparentes, em camadas } \\
\text { decimétricas lateralmente contínuas } \\
\text { por dezenas de metros e localmente } \\
\text { em lentes centimétricas que passam } \\
\text { lateralmente para areias ricas em } \\
\text { intraclastos pelíticos. }\end{array}$ & $\begin{array}{l}\text { Depósitos de decantação em } \\
\text { águas calmas em ambientes } \\
\text { restritos de topos de barras e } \\
\text { planícies de inundação. }\end{array}$ & $\begin{array}{l}\text { Compondo sucessões espessas de } \\
\text { depósitos finos com F5 e F6 e } \\
\text { localmente em lentes } \\
\text { centimétricas associadas a F4. }\end{array}$ \\
\hline
\end{tabular}

Acima dessa porção basal, ocorre sucessão de 5 a 15 metros de espessura de arenitos médios a finos dispostos em cosets lateralmente contínuos de estratificação cruzada tabular ou acanalada, com séries individuais de 7 a $35 \mathrm{~cm}$ de espessura. Sucessões de topo desses 
grandes ciclos granocrescentes são caracterizadas por intercalações de pelitos laminados em camadas decimétricas lateralmente descontínuas, associadas a arenitos finos com laminação cruzada cavalgante. Essas fácies finas ocorrem às vezes como estratos basais de séries isoladas de estratos cruzados de 1 a $4 \mathrm{~m}$ de espessura, em arenitos finos a médios, que passam lateralmente para cosets inclinados. As sucessões grano-decrescentes são interpretadas como perfis de preenchimento de canais por migração de barras arenosas, sendo a porção de topo interpretada como ambiente de topo de barra, com barras unitárias migrando sobre corpos isolados de lama.

Figura 14 - (A) Arenitos com estratificações cruzadas acanaladas de médio porte (F2). (B) e (C) Fácies pelitos arenosos com laminação cruzada (F5)
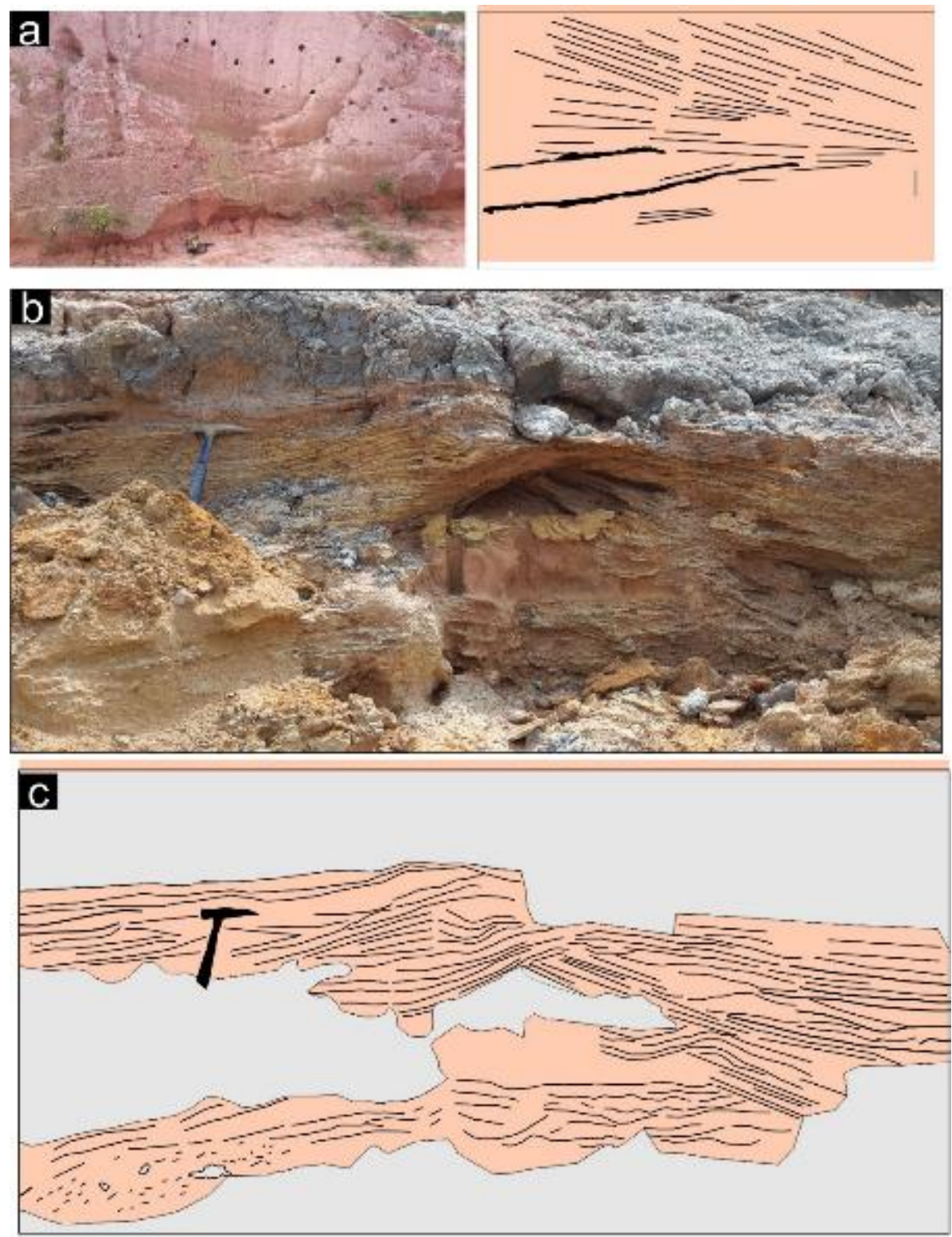

Fonte: Elaborada por André G. Stern. 
Figura 15 - (A) Detalhes dos depósitos de baixa energia, silte em cinza, laminações cruzadas em siltito heterolítico e siltito argiloso (F5), recobertos por argilito maciço (F7). (B) Detalhes do levantamento da coluna estratigráfica ALC 28, no Solimões, nas proximidades de Tefé (AM)
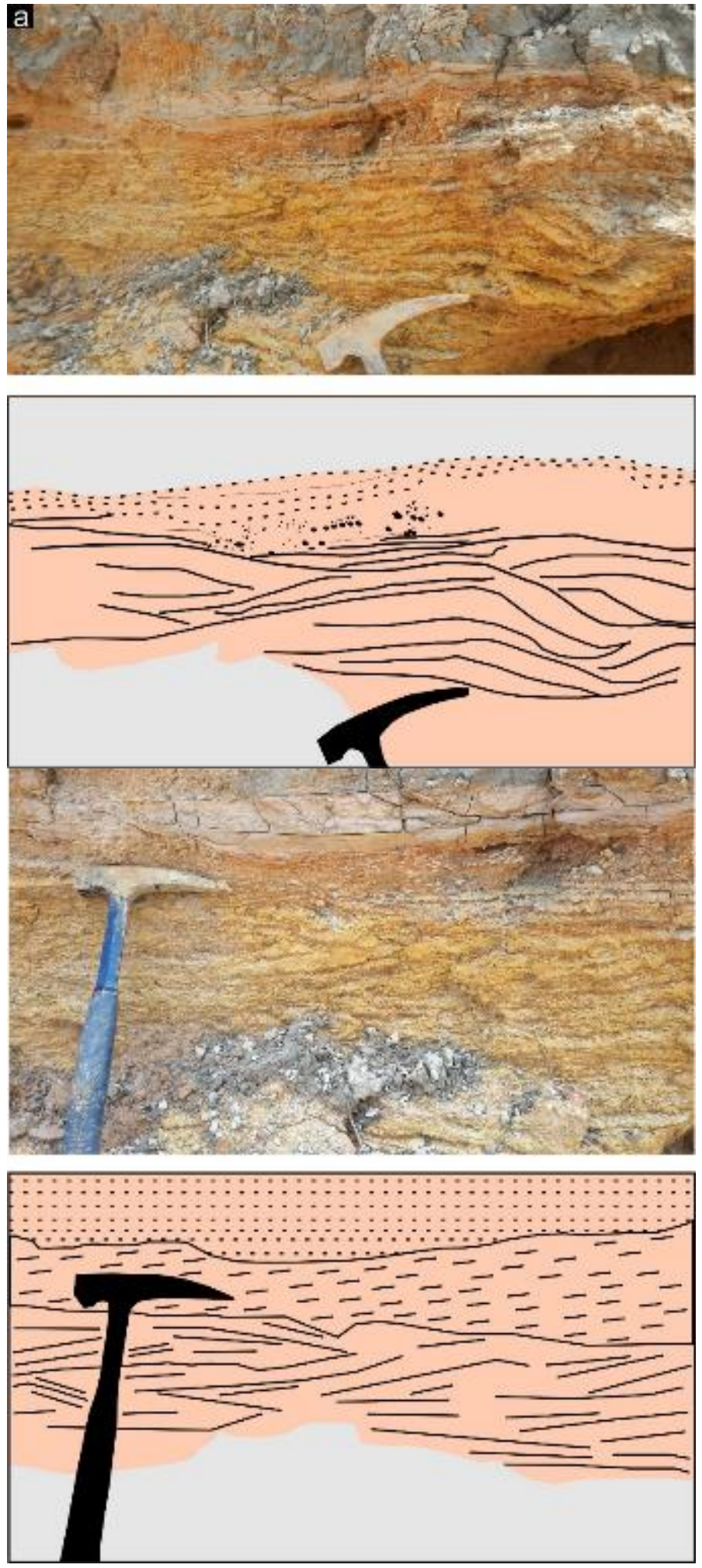

Fonte: Elaborada por André G. Stern. 
Figura 16 - Detalhe das estruturas sedimentares encontradas na seção. Laminações cruzadas em camada siltosa (F5) com intraclastos de argila (F6)
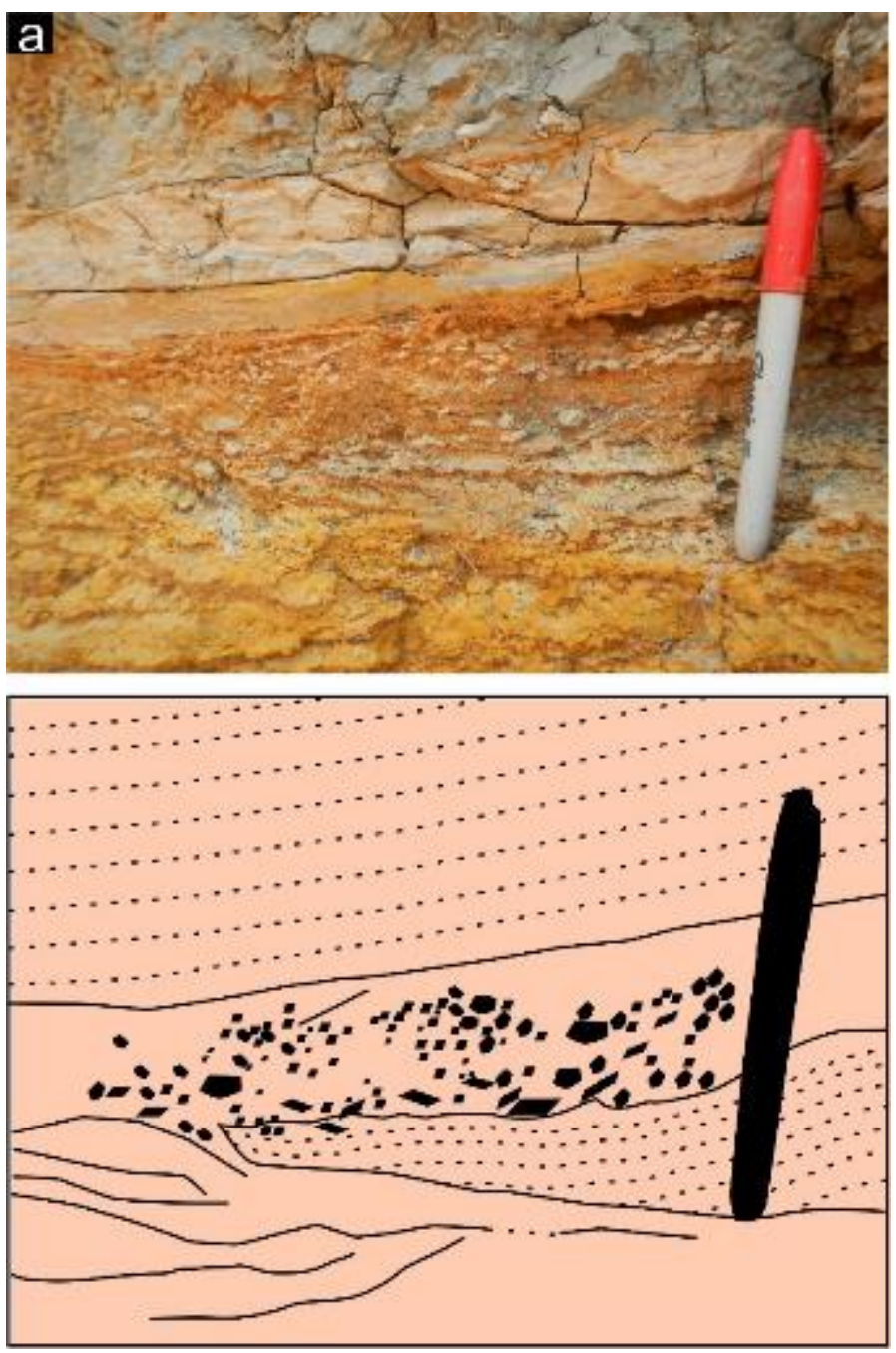

Fonte: Elaborada por André G. Stern. 
Figura 17 - Levantamento de coluna estratigráfica ALC 28, no Solimões, próximo à cidade de Tefé (AM). As imagens ilustram fácies arenosas com estratificação cruzada tabular (F3) e acanalada (F2). Acima, observam-se arenitos médios, sets com estratificações cruzadas tabulares de porte pequeno a médio, com lentes tabulares de argila e seus limites de séries
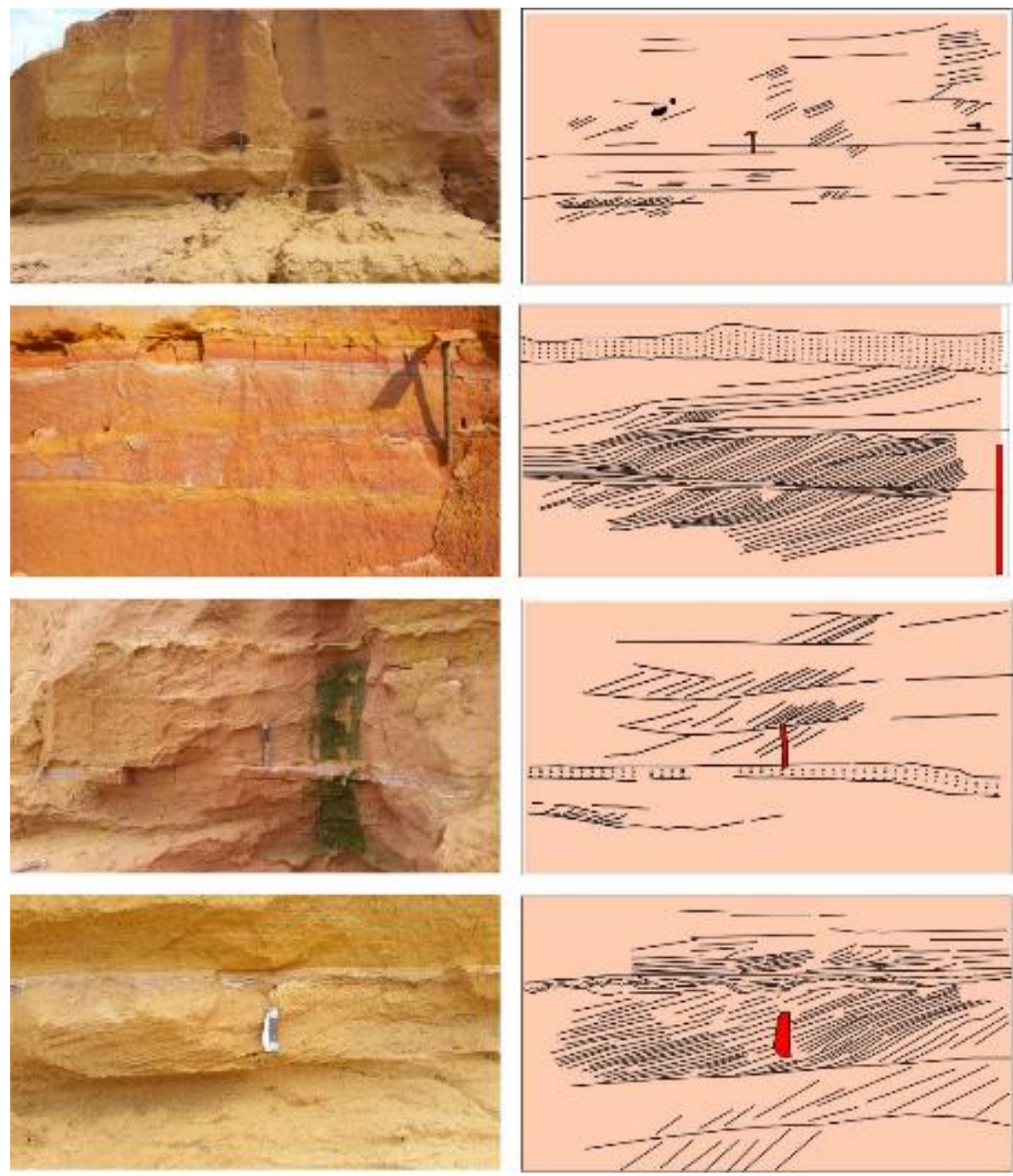

Fonte: Elaborada por André G. Stern. 
Figura 18 - Detalhes da seção do rio Içá (ALC 35), com atenção às fácies de siltito com laminação cruzada e areia muito fina (F5, fotos superiores) e conglomerados de intraclastos com estratificações cruzadas (F6, fotos inferiores)
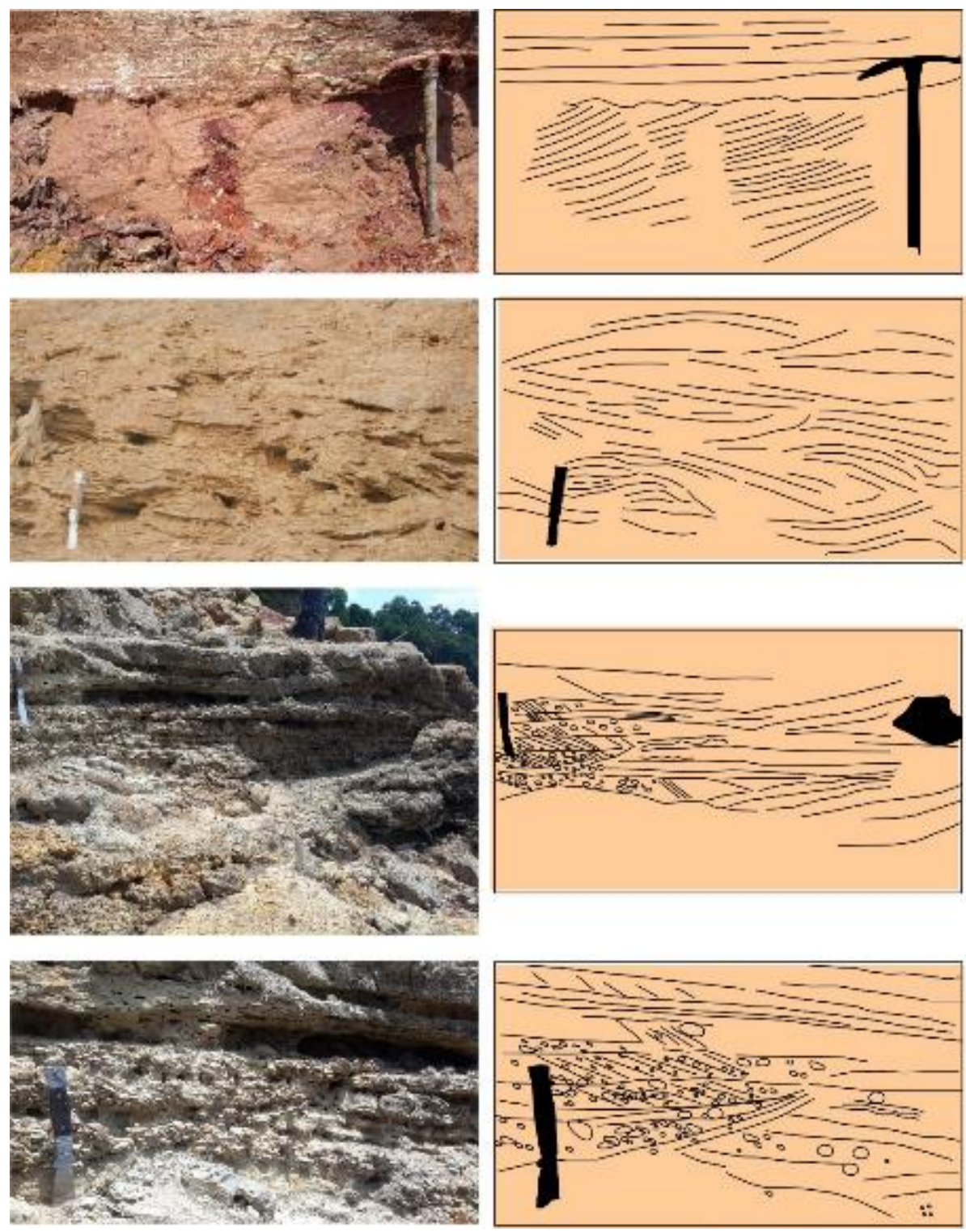

Fonte: Elaborada por André G. Stern. 
Figura 19 - Colunas estratigráficas de sedimentos de terraço de Terra Firme relativo ao estágio III: ALC 26 Rio Solimões nas proximidades de Coari (AM); ALC 28 Rio Solimões nas proximidades de Tefé (AM). Colunas estratigráficas de sedimentos de terraço de Terra Firme relativo ao estágio II:

ALC 35 Rio Içá e ALC 36 Rio Solimões em Santo Antônio do Içá (AM)
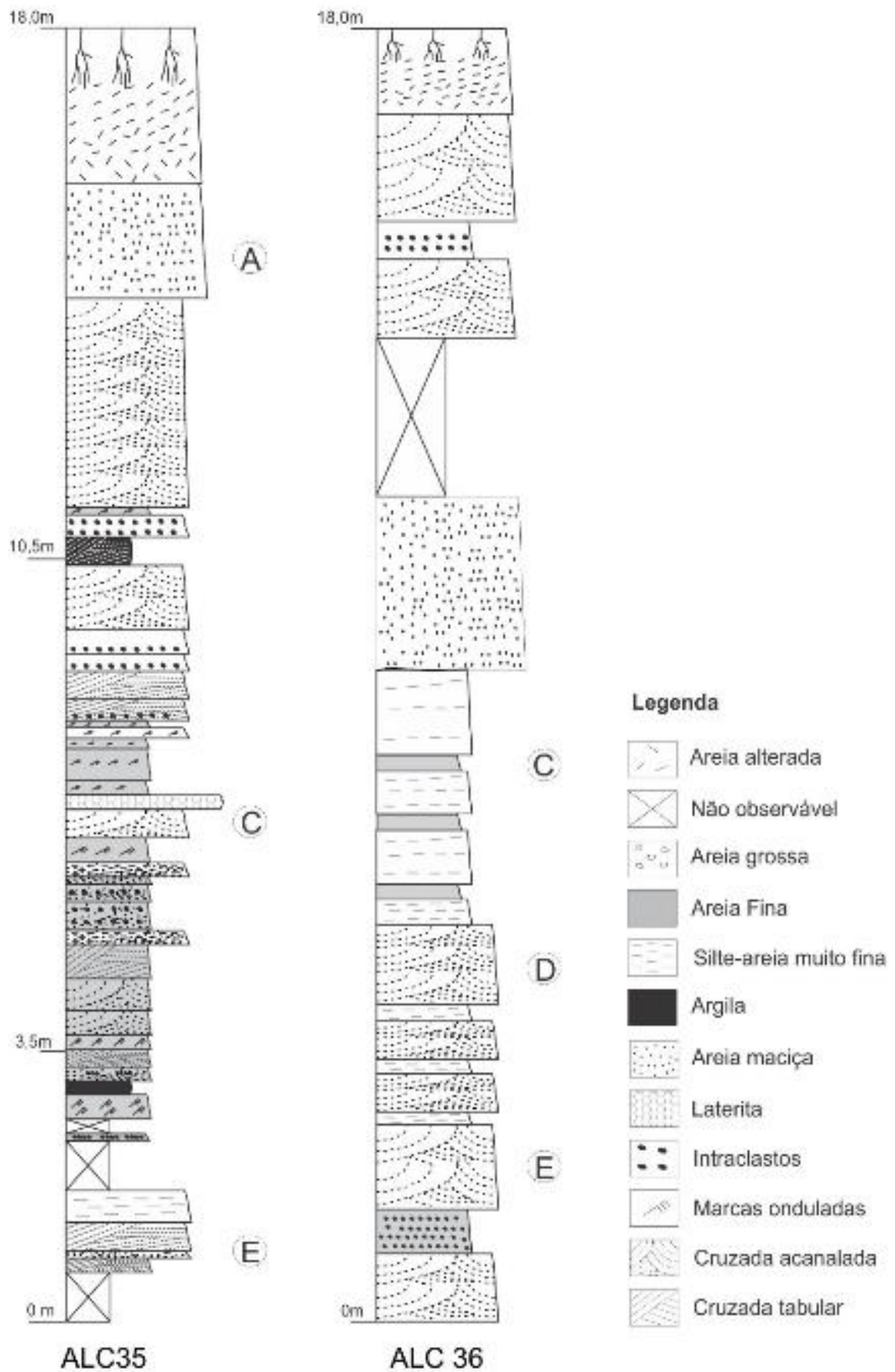

Fonte: Elaborada por André G. Stern. 
Nos afloramentos estudados, foram reconhecidas três associações de fácies com base na relação espacial de elementos arquiteturais com geometria definida e recorrência de fácies sedimentares (Quadro 7).

Quadro 7 - Associação entre fácies e elementos arquiteturais dos terraços de Terra Firme

\begin{tabular}{|c|c|c|c|}
\hline $\begin{array}{l}\text { Associação } \\
\text { entre fácies e } \\
\text { elementos } \\
\text { arquiteturais }\end{array}$ & Elementos arquiteturais & Descrição & Interpretação \\
\hline \multirow{3}{*}{$\begin{array}{l}\text { Planícies de } \\
\text { inundação }\end{array}$} & $\begin{array}{c}\text { Cunhas de arenitos e pelitos } \\
\text { laminados }\end{array}$ & $\begin{array}{l}\text { Corpos de até } 6 \mathrm{~m} \text { de espessura, } \\
\text { dominados pela fácies F5, com limites } \\
\text { de séries inclinados de poucos graus, } \\
\text { geralmente tangenciando na base, } \\
\text { compondo cunhas de estratos inclinados } \\
\text { ou sigmoidais. Localmente, ocorrem } \\
\text { intercalações de F6 e F7. }\end{array}$ & $\begin{array}{c}\text { Barras de desembocadura em } \\
\text { ambientes calmos e restritos, } \\
\text { incluindo lagos marginais aos } \\
\text { canais, rias e meandros } \\
\text { abandonados. }\end{array}$ \\
\hline & Pelitos tabulares & $\begin{array}{c}\text { Camadas contínuas, decimétricas a } \\
\text { métricas, dominadas pela fácies F7, } \\
\text { com intercorrências de F5 em séries } \\
\text { horizontais. }\end{array}$ & $\begin{array}{l}\text { Depósitos de decantação e } \\
\text { correntes episódicas em } \\
\text { desaceleração em ambientes } \\
\text { calmos e restritos, incluindo } \\
\text { lagos marginais aos canais, } \\
\text { rias e meandros abandonados }\end{array}$ \\
\hline & $\begin{array}{l}\text { Lentes de conglomerados de } \\
\text { intraclastos }\end{array}$ & $\begin{array}{l}\text { Lentes com continuidade lateral métrica } \\
\text { a decamétrica, com base erosiva, } \\
\text { contendo conglomerados e arenitos } \\
\text { conglomeráticos da fácies F6 com } \\
\text { intraclastos imbricados e estratificação } \\
\text { horizontal ou cruzada, às vezes } \\
\text { paralelas a escavações basais com } \\
\text { comprimento de onda decimétrico. }\end{array}$ & $\begin{array}{l}\text { Correntes em canais } \\
\text { secundários ou picos de } \\
\text { vazão em planícies de } \\
\text { inundação retrabalhando } \\
\text { depósitos de decantação. }\end{array}$ \\
\hline Barras fluviais & $\begin{array}{c}\text { Cosets de arenitos com } \\
\text { estratificação cruzada (F2, F3 } \\
\text { e F1) }\end{array}$ & $\begin{array}{c}\text { Conjuntos métricos (até } 4 \mathrm{~m} \text { ) de séries } \\
\text { de arenitos com estratificação cruzada } \\
\text { F2 e F3 e limites de série inclinados a } \\
\text { baixos ângulos em direção semelhante à } \\
\text { dos estratos cruzados. Ocorrência local } \\
\text { de arenitos maciços (F1). }\end{array}$ & $\begin{array}{c}\text { Migração de dunas na } \\
\text { superficie de porções } \\
\text { submersas de barras fluviais. }\end{array}$ \\
\hline \multirow{3}{*}{$\begin{array}{l}\text { Topos de barras } \\
\text { e canais } \\
\text { secundários }\end{array}$} & $\begin{array}{c}\text { Cosets de arenitos com } \\
\text { estratificação cruzada (F2, F3 } \\
\text { e F1) }\end{array}$ & $\begin{array}{c}\text { Conjuntos métricos (até } 4 \mathrm{~m} \text { ) de séries } \\
\text { de arenitos com estratificação cruzada } \\
\text { F2 e F3 e limites de série inclinados a } \\
\text { baixos ângulos em direção semelhante à } \\
\text { dos estratos cruzados. Ocorrência local } \\
\text { de arenitos maciços (F1). }\end{array}$ & $\begin{array}{c}\text { Migração de dunas na } \\
\text { superfície de porções } \\
\text { submersas de barras fluviais e } \\
\text { em talvegues de canais } \\
\text { secundários. }\end{array}$ \\
\hline & $\begin{array}{c}\text { Migração de depósitos de } \\
\text { avalanche em laterais de } \\
\text { barras (F4) }\end{array}$ & $\begin{array}{c}\text { Séries de espessura métrica de arenitos } \\
\text { com cruzadas tabulares da fácies F4, } \\
\text { com geometria em cunha e } \\
\text { continuidade lateral por dezenas de } \\
\text { metros. }\end{array}$ & $\begin{array}{c}\text { Depósitos de laterais e frentes } \\
\text { ingremes de barras unitárias } \\
\text { nas proximidades dos topos } \\
\text { das barras. }\end{array}$ \\
\hline & Lentes de pelitos (F7) & $\begin{array}{c}\text { Camadas centimétricas a decimétricas } \\
\text { horizontais da fácies } \mathrm{F} 7, \text { com } \\
\text { continuidade } \\
\text { lateral. }\end{array}$ & $\begin{array}{l}\text { Depósitos de decantação em } \\
\text { áreas protegidas de canais } \\
\text { secundários e topos de barras. }\end{array}$ \\
\hline
\end{tabular}

Fonte: Elaborada por André G. Stern. 


\subsection{Associação de fácies de planícies de inundação}

Depósitos dominados por decantação (F7), correntes em desaceleração gerando laminação cruzada cavalgante em areia fina e mesmo pelitos floculados (F5) e retrabalhamento de depósitos finos como intraclastos (F6) são predominantes nos níveis inferiores de exposição dos terraços do estágio III e na maior parte das colunas estratigráficas dos terraços do estágio II investigadas. Geometrias em cunha ou sigmoidais de associações das fácies F7 e F5 são comuns na base dos terraços do estágio III (Figura 20), onde fragmentos de troncos fósseis são localmente abundantes (Figura 18).

Figura 20 - Exemplo de depósitos de planícies de inundação compostos por cunhas de arenitos e pelitos laminados e ocorrência local de lentes de conglomerados de intraclastos e pelitos tabulares.

Afloramento NAM 04
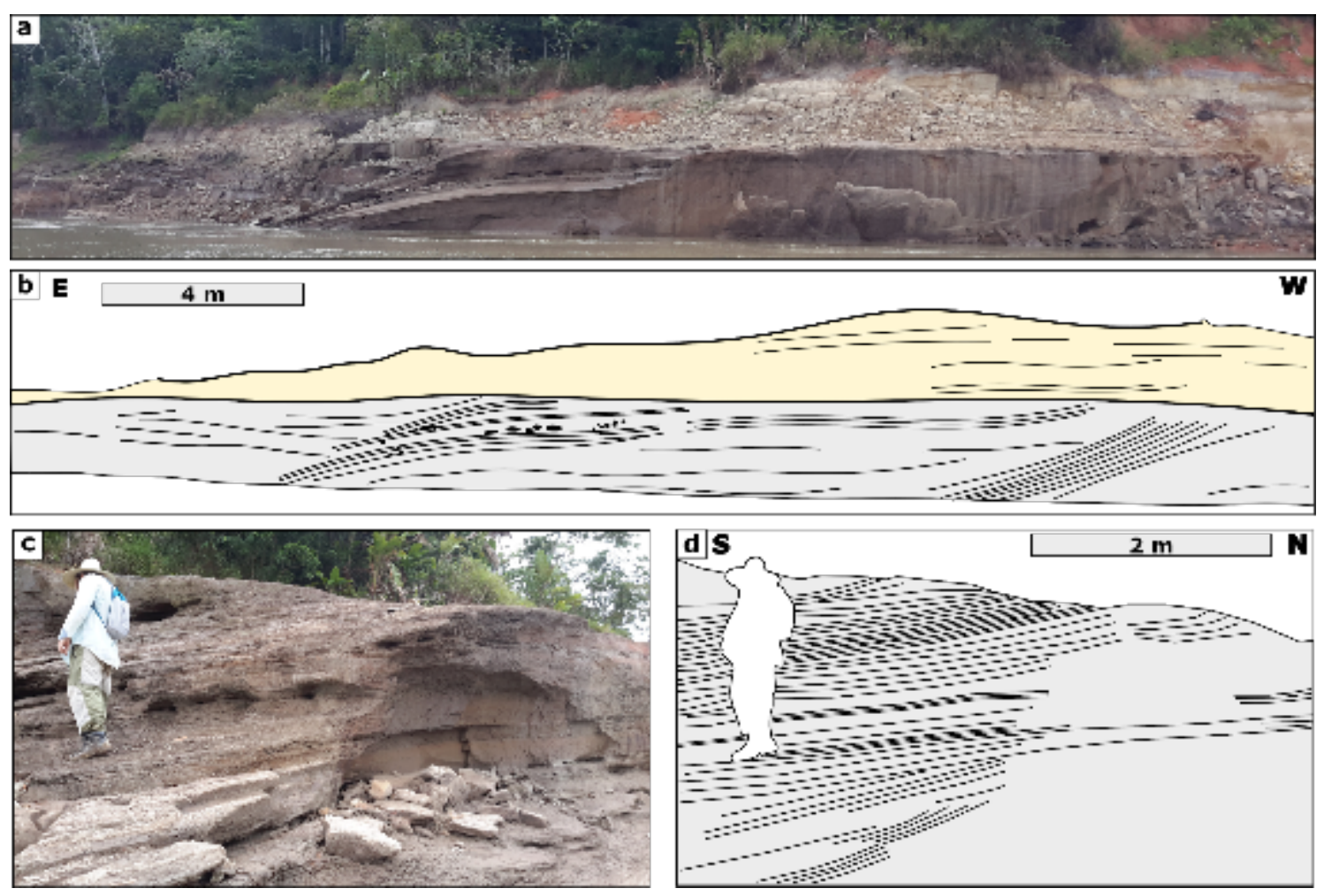

Fonte: Elaborada por André G. Stern.

As características desses depósitos revelam ambientes com alternância da capacidade de transporte, ora suficiente para transportar seixos, ora permitindo deposição da carga de suspensão fina, mas com aporte muito limitado de areia, mesmo em elementos de barras de desembocadura. Situações semelhantes são encontradas em planícies de inundação 
permanentemente inundadas nas margens do rio Amazonas ativo, e sua abundância em terraços pleistocênicos no Solimões, onde lagos permanentes de planície de inundação são mais raros, deve refletir ambientes aluviais com declividades semelhantes às do moderno Amazonas.

\subsection{Associação de fácies de barras fluviais}

Os depósitos mais comuns nos afloramentos visitados dos sistemas de terraços pleistocênicos da Amazônia Central são dominados por areias com estratificação cruzada tabular e acanalada, com ocorrência local de grânulos e níveis de intraclastos pelíticos (Figura 21 até aproximadamente $13 \mathrm{~m}$, abaixo da camada pelítica mais espessa). As estratificações estão dispostas em séries decimétricas separadas por limites inclinados em baixo ângulo compondo cosets métricos (Figura 22), geralmente com inclinação em rumo semelhante ao das estratificações cruzadas (Figura 23).

Essa associação de fácies é perfeitamente compatível com os depósitos reconhecidos por Galeazzi et al. (2018) e Tamura (2019) como porções submersas de barras fluviais (Figura 24), com a particularidade de terem sido observadas apenas seções com acréscimo frontal (Figura 23), possivelmente em decorrência de amostragem limitada. Destaca-se que a pequena espessura dos afloramentos investigados com relação à profundidade dos canais principais de rios do porte dos tributários de primeira ordem do Solimões deve ter sido responsável pelo não reconhecimento de depósitos de talvegue semelhantes aos descritos por Almeida et al. (2016) e Galeazzi et al. (2018) em sistemas ativos. 
Figura 21 - Seção colunar do ALC 28 (Tefé, AM), composta pela associação de fácies de barras fluviais da base até aproximadamente $13 \mathrm{~m}$ e pela associação de fácies de topos de barras e canais secundários acima de $13 \mathrm{~m}$

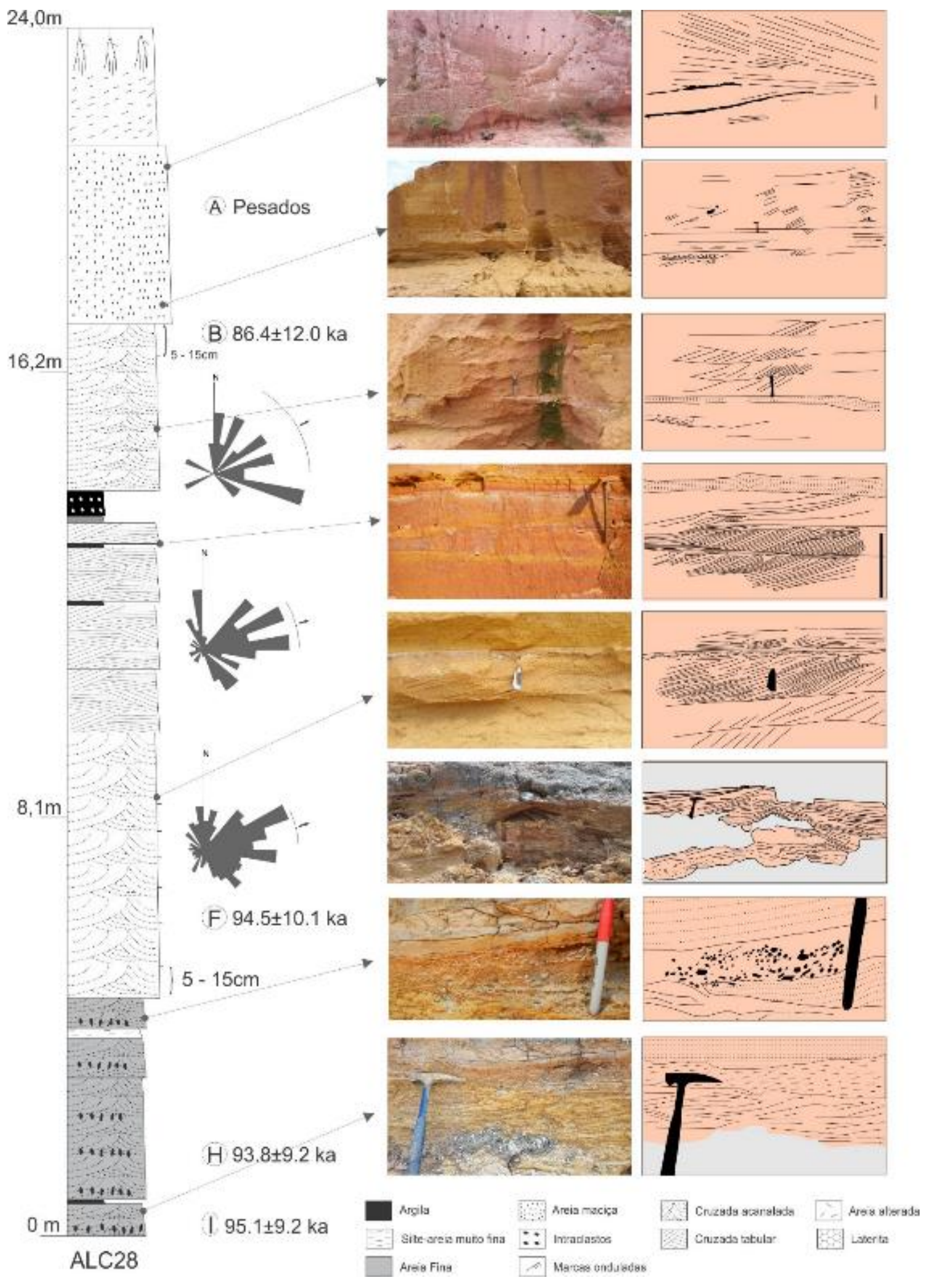

Fonte: Elaborada por André G. Stern. 
Figura 22- Exemplo de depósitos de barras fluviais compostos por séries de arenitos com estratificação cruzada e limites inclinados em direção semelhante ao paleofluxo (estereograma obtido com método de Almeida et al., 2015). Afloramento NAM 05
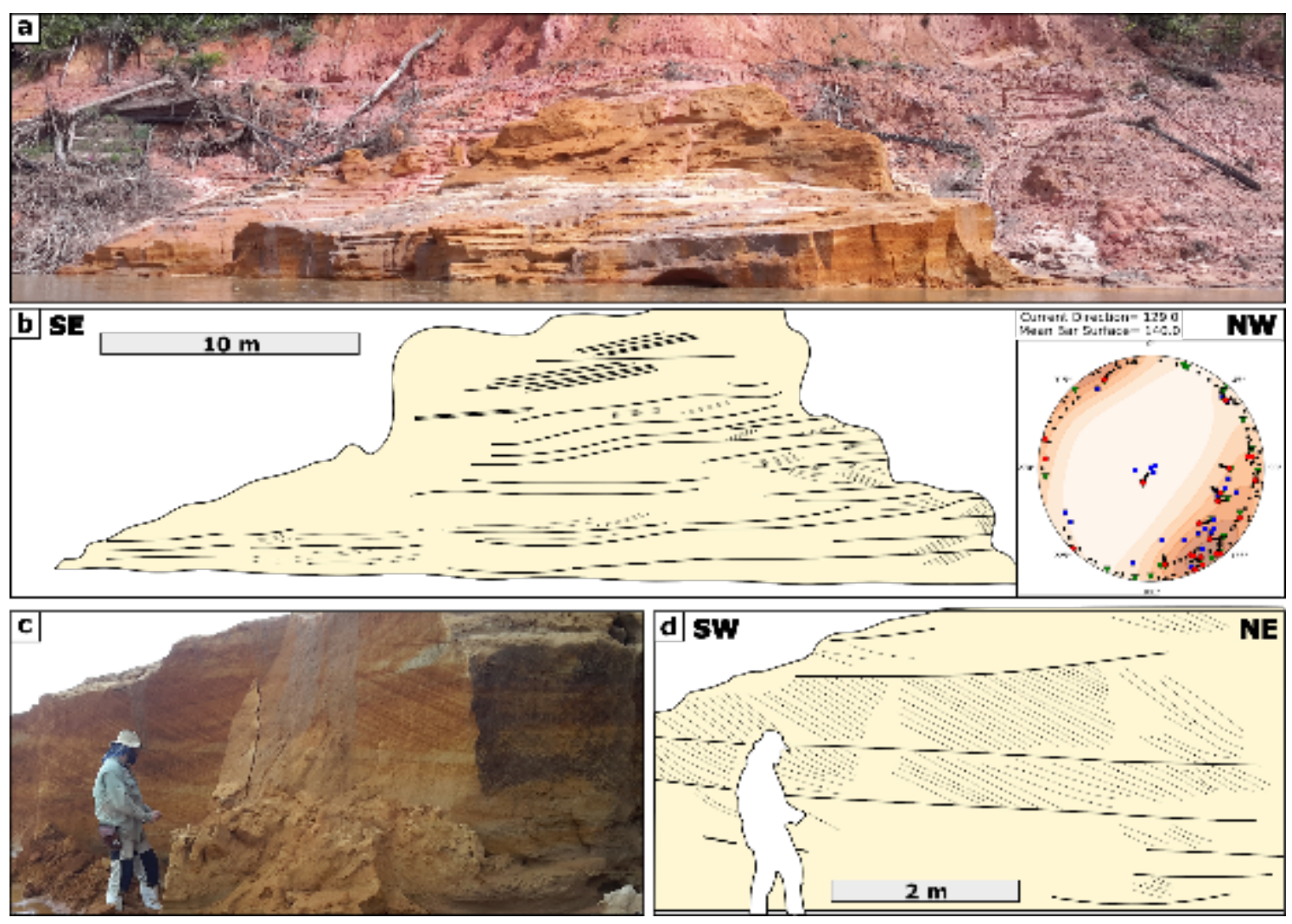

Fonte: Elaborada por André G. Stern. 
Figura 23 - Projeções estereográficas (hemisfério inferior, equal angle) das medidas de estratos cruzados e limites de séries (rumo do mergulho representado como linha) e cálculo da orientação da superfície das barras para cada coset de acordo com o método de Almeida et al. (2015). Associação de fácies de planícies de inundação: ALC 26, NAM 11; associação de fácies de barras fluviais: ALC 28b, ALC 45, NAM 05, NAM 08, NAM 09; associação de fácies de topo de barras e canais secundários:

NAM 03, ALC 28a. Em todas as associações de fácies e elementos arquiteturais investigados predominam ângulos pequenos entre o rumo da corrente e o mergulho da barra, indicando acréscimo frontal ou oblíquo

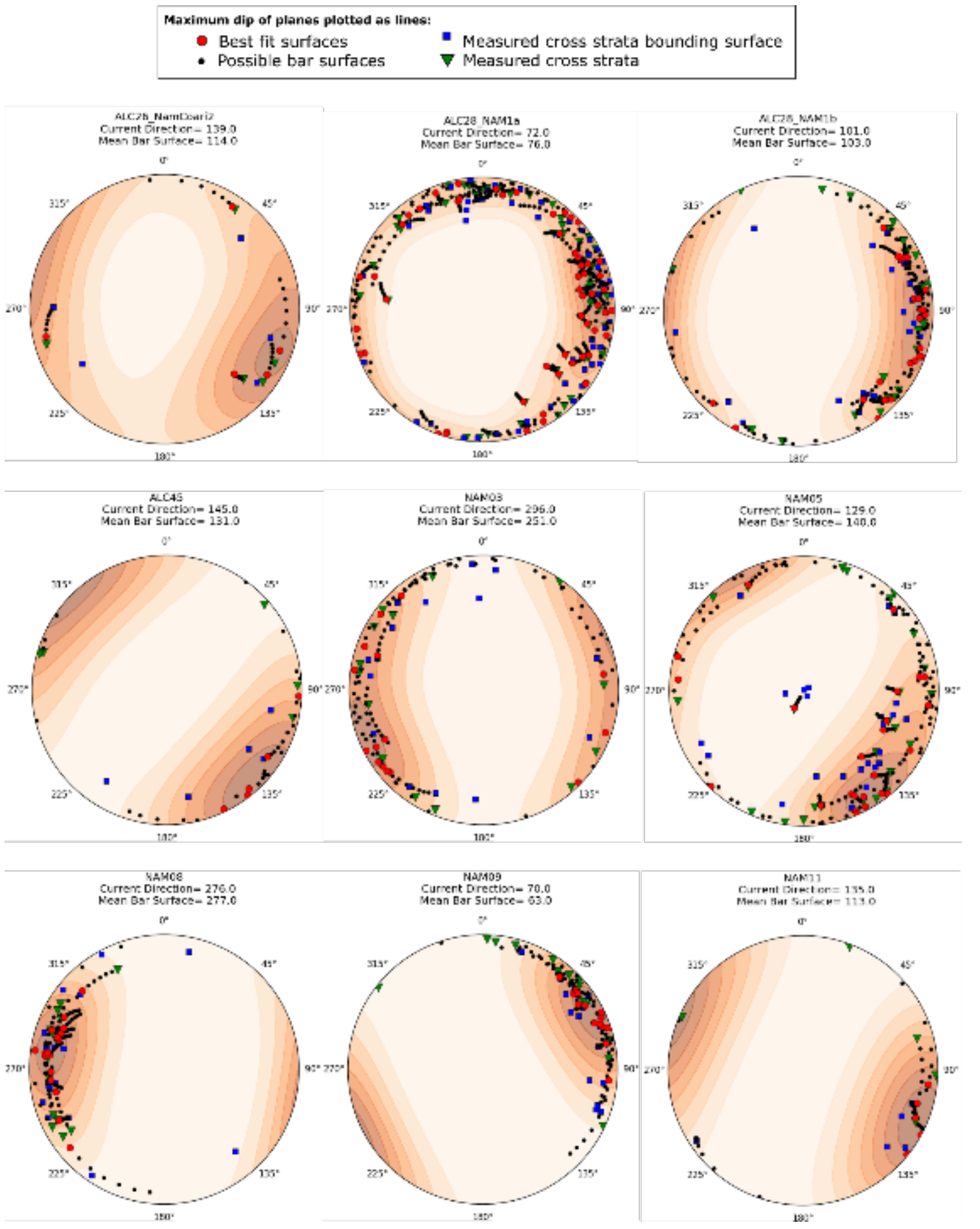

Fonte: Elaborada por André G. Stern. 
Figura 24 - Morfologia de dunas migrando sobre barras e canal secundário próximo à ilha da Xiborena, Baixo Solimões, a partir de dados de ecobatímetro multifeixe
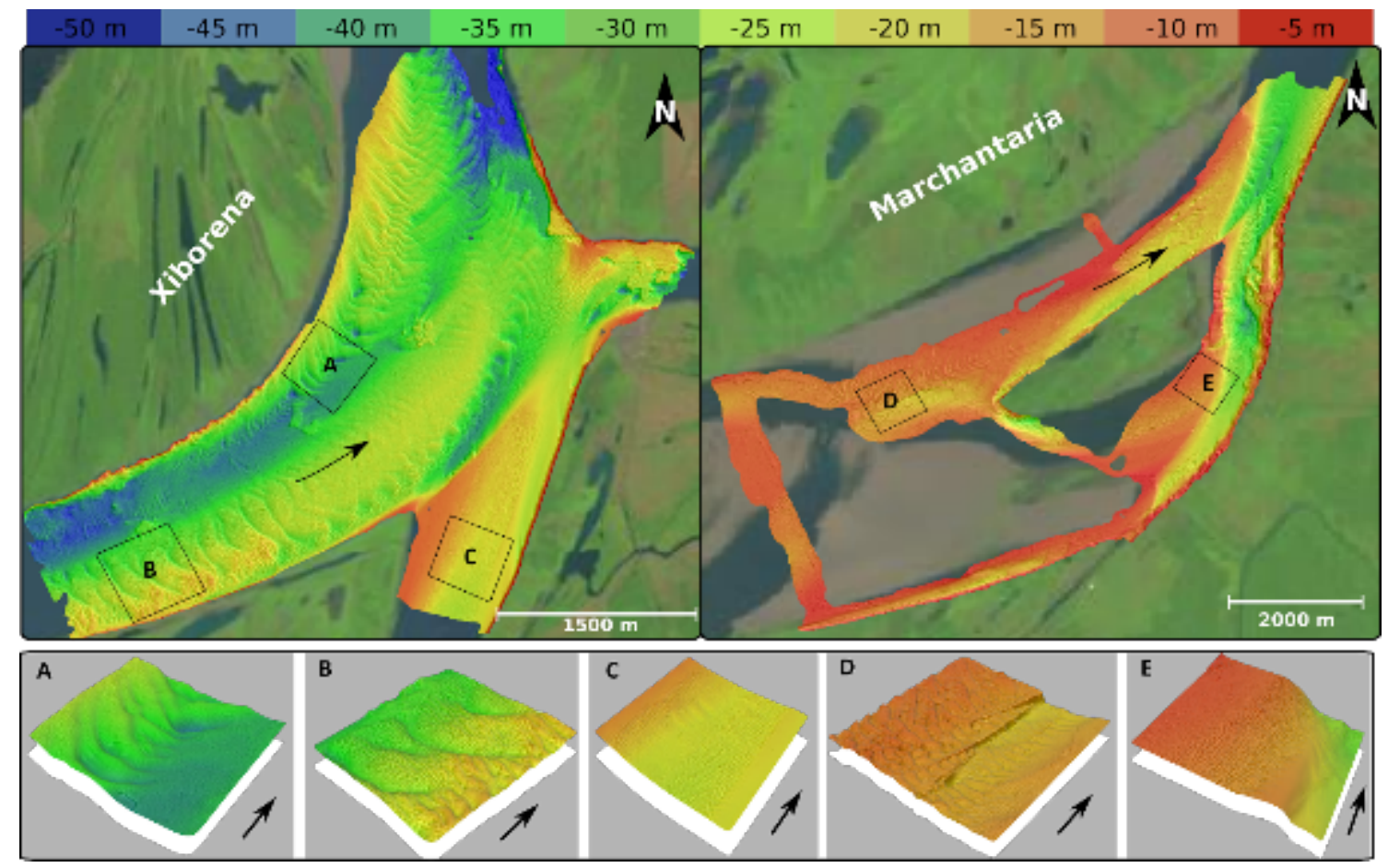

Fonte: Extraído de Tamura (2019).

\subsection{Associação de fácies de topos de barra e canais secundários}

Entre as associações de fácies reconhecidas, a que apresenta a maior variabilidade de fácies e geometrias deposicionais ocorre geralmente nas proximidades do topo dos perfis levantados (Figura 21). A associação é caracterizada por depósitos arenosos e lamosos intercalados, revelando grande variação de potência de corrente em ciclos sazonais de exposição e retrabalhamento. 
Figura 25 - Seção colunar ALC 35, no rio Içá. Trata-se do local mais próximo possível do que seria a seção-tipo da Formação Içá descrita por Maia et al. (1977), aqui relacionada ao estágio II dos sistemas de terraços pleistocênicos. A seção revela a variedade de fácies da associação de topos de barras e canais secundários

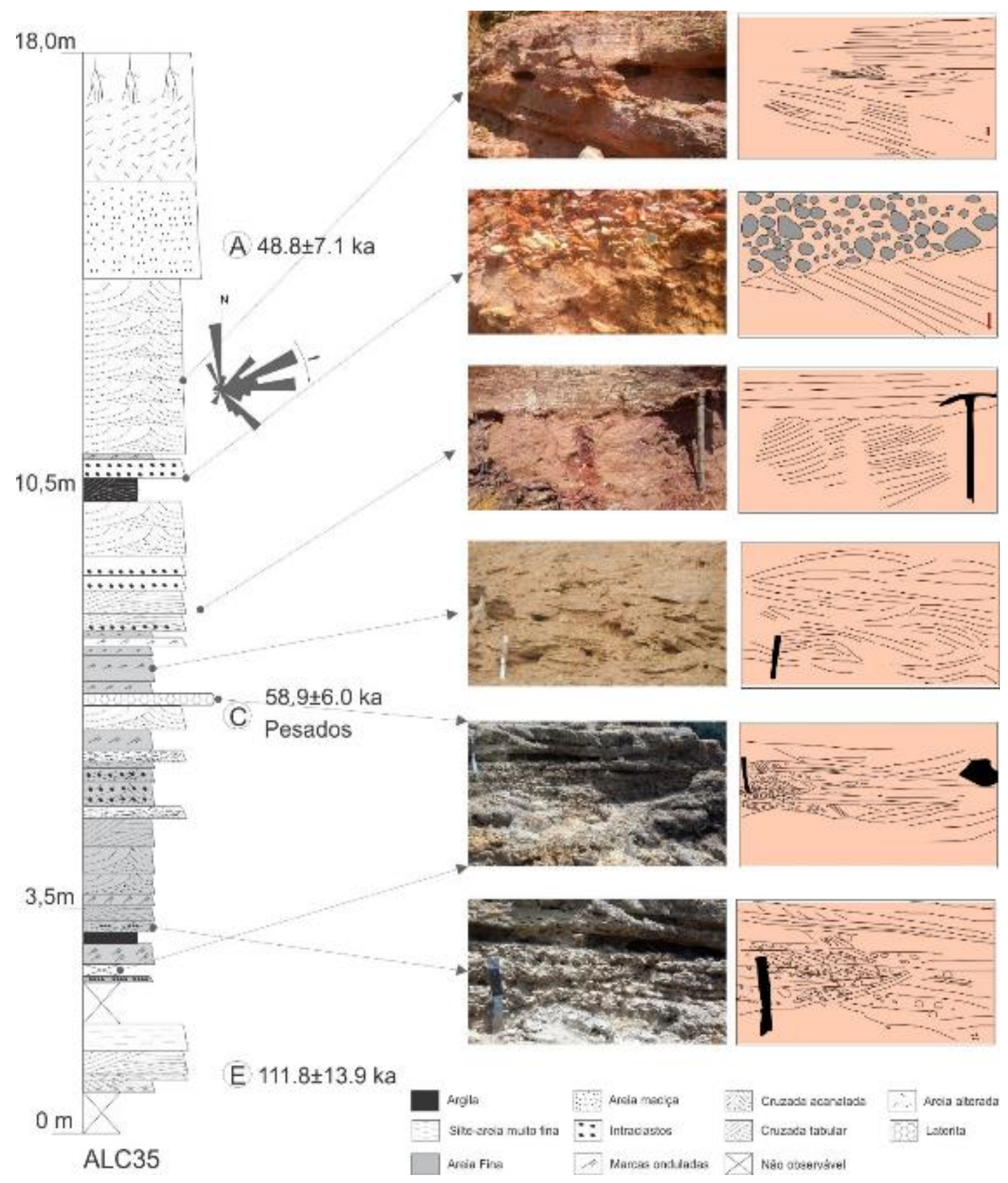

Fonte: Elaborada por André G. Stern. 
Figura 26 - Exemplo de depósitos de barras fluviais compostos por séries de arenitos com estratificação cruzada e limites inclinados em direção semelhante ao paleofluxo (estereograma obtido com o método de Almeida et al., 2015). Afloramento NAM 05
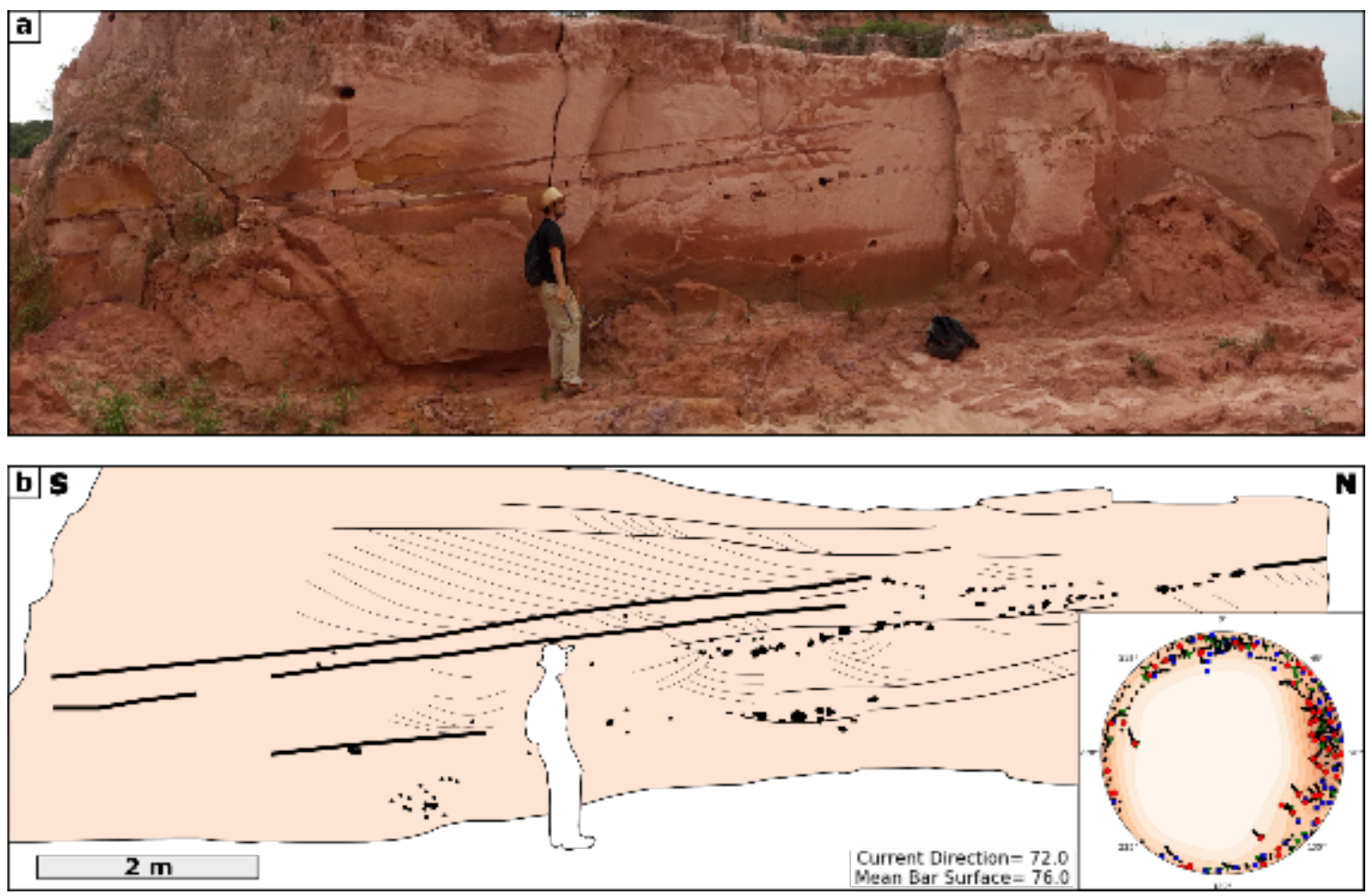

Fonte: Elaborada por André G. Stern.

Figura 27 - Imagens de radar de penetração de solo em barra ativa no Baixo Solimões, ilha da Marchantaria, mostrando elementos de migração de lateral de barra formando cruzada de alto ângulo e elementos de cosets de estratificação cruzada por migração de dunas em topo de barra

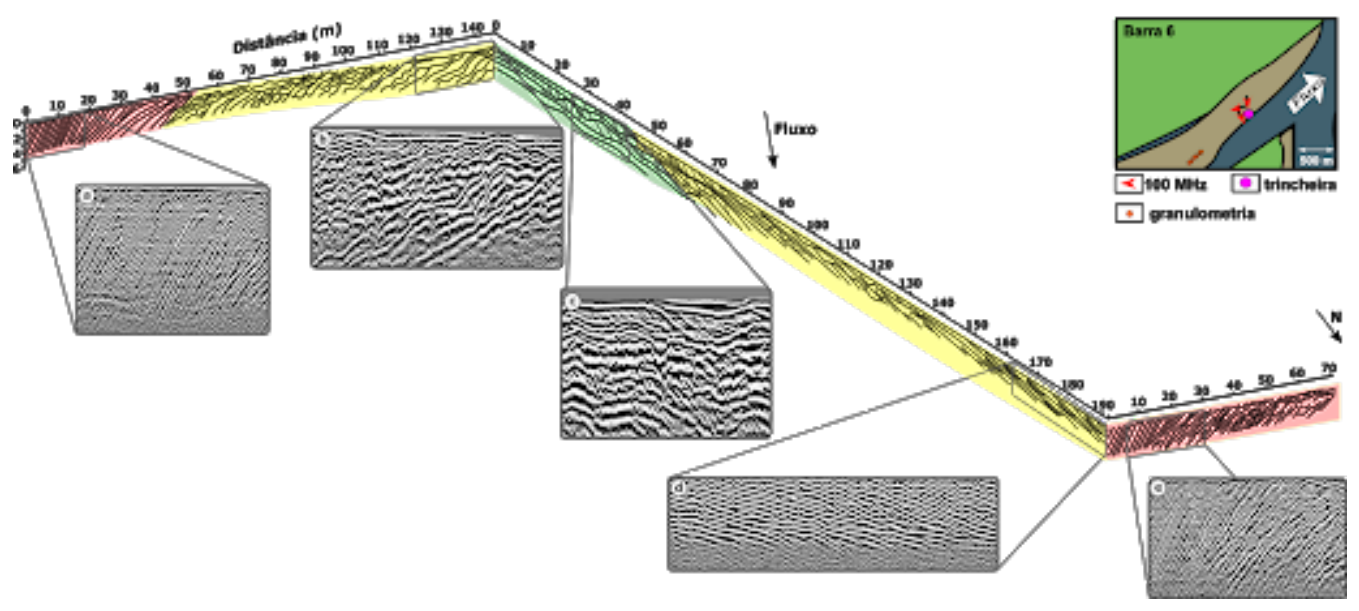

Fonter: Extraído de Tamura (2019). 
Figura 28 - Levantamento de coluna estratigráfica ALC 35, no rio Içá. Trata-se da melhor exposição encontrada desses depósitos. O afloramento superior representa a seção, com detalhe no canal fluvial com depósito conglomeráticos heterolíticos no topo da estrutura. Esse afloramento é muito semelhante ao descrito por Maia et al. (1977) nos arredores da cidade de Santo Antônio do Içá (AM)
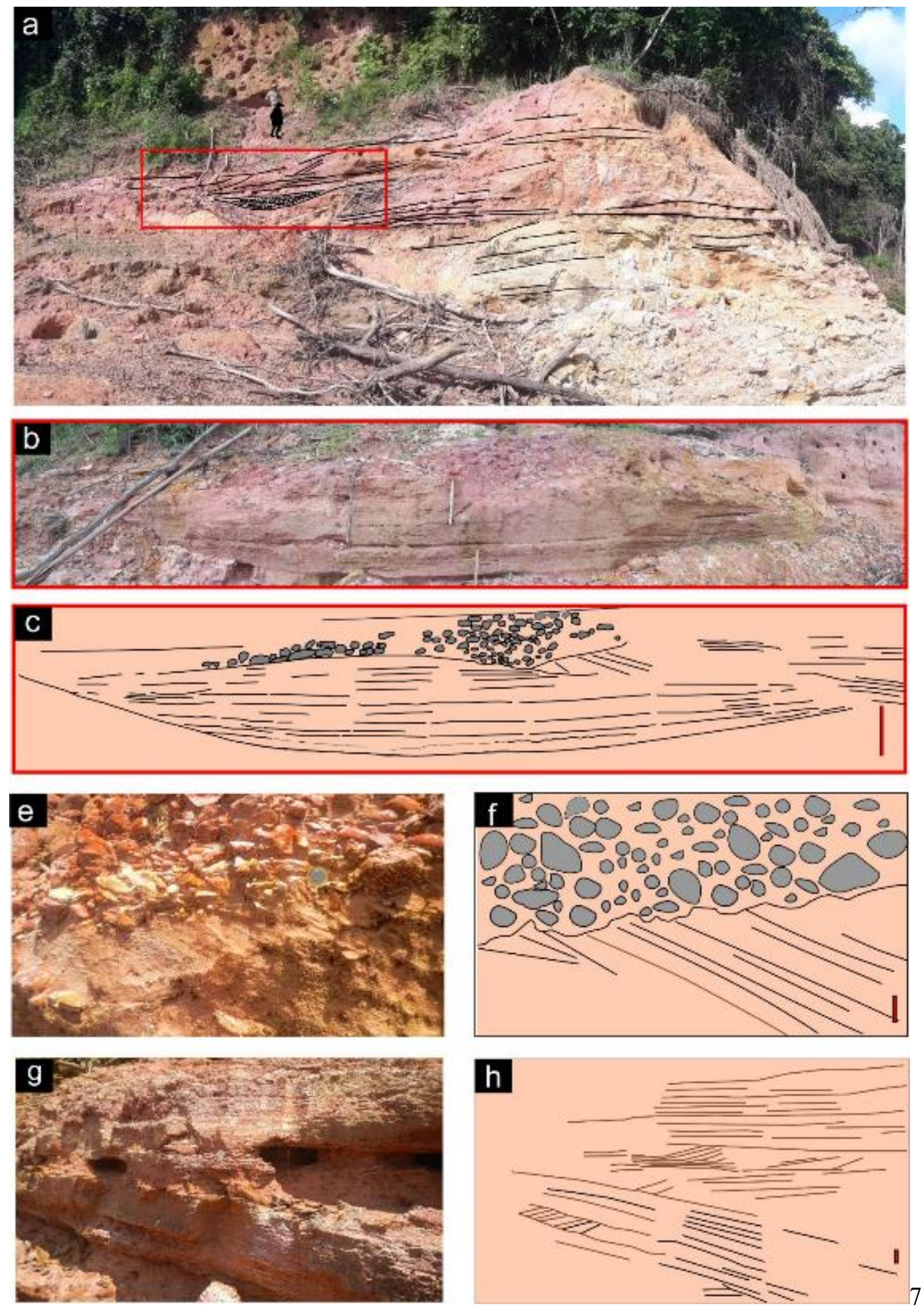

Fonte: Elaborada por André G. Stern. 


\section{PROVENIÊNCIA E PALEOCORRENTES DOS TERRAÇOS PLEISTOCÊNICOS DA AMAZÔNIA CENTRAL}

\subsection{Minerais pesados e índices mineralógicos}

As amostras obtidas em terraços quaternários dos estágios II e III (anteriormente mapeados como Formação Içá) caracterizam-se pela predominância de minerais pesados opacos (média de 70\%). Por outro lado, os minerais translúcidos mais abundantes (80 a $100 \%)$ são zircão $(\mathrm{M}=58 \%)$, turmalina $(\mathrm{M}=12 \%)$, estaurolita $(\mathrm{M}=8 \%)$, rutilo $(\mathrm{M}=7 \%)$, cianita $(M=6 \%)$ e sillimanita $(M=3 \%)$ (Quadros 8 e 9, Gráficos 2 a 5 e Figuras 29 e 30).

Quadro 8 - Resultado da contagem de grãos de minerais pesados

\begin{tabular}{ccccccccccccccc}
\hline \multirow{2}{*}{ Amostra } & \multicolumn{10}{c}{ Contagem de minerais pesados (\%) } \\
\cline { 2 - 7 } & Z & T & R & Afs & Opx & Cpx & St & Ep & SI & Ky & Az & Ap & Gt & Olv \\
\hline ALC 35C & 54 & 9 & 7 & 0 & 0 & 0 & 14 & 0 & 1 & 15 & 0 & 0 & 0 & 0 \\
\hline ALC 36D & 53 & 12 & 7 & 8 & 0 & 0 & 11 & 0 & 8 & 1 & 0 & 0 & 0 & 0 \\
\hline ALC 37C & 46 & 17 & 5 & 0 & 0 & 0 & 2 & 0 & 7 & 7 & 15 & 0 & 1 & 0 \\
\hline ALC 28A & 66 & 15 & 9 & 0 & 0 & 0 & 0 & 1 & 1 & 6 & 0 & 0 & 2 & 0 \\
\hline ALC 26D & 69 & 7 & 9 & 0 & 0 & 0 & 0 & 0 & 6 & 7 & 0 & 0 & 2 & 0 \\
\hline MAO 170 & 4 & 3 & 1 & 50 & 8 & 10 & 0 & 19 & 0 & 3 & 0 & 0 & 2 & 0 \\
\hline MAO 175 & 5 & 0 & 1 & 20 & 16 & 29 & 0 & 24 & 0 & 5 & 0 & 0 & 0 & 0 \\
\hline MAO 162 & 11 & 0 & 1 & 24 & 15 & 15 & 0 & 30 & 0 & 0 & 0 & 0 & 4 & 0 \\
\hline MAO 164 & 5 & 1 & 1 & 21 & 21 & 29 & 0 & 17 & 0 & 2 & 0 & 0 & 3 & 0 \\
\hline MAO 179 & 3 & 0 & 2 & 21 & 21 & 31 & 0 & 15 & 0 & 0 & 0 & 2 & 5 & 0 \\
\hline MAO 154 & 4 & 1 & 0 & 24 & 23 & 21 & 0 & 21 & 0 & 0 & 0 & 0 & 6 & 0 \\
\hline MAO 160 & 70 & 5 & 3 & 2 & 1 & 4 & 0 & 12 & 0 & 0 & 0 & 0 & 3 & 0 \\
\hline MAO 151 & 5 & 0 & 0 & 23 & 26 & 25 & 0 & 20 & 0 & 0 & 0 & 0 & 1 & 0 \\
\hline MAO 184A & 9 & 0 & 2 & 36 & 14 & 13 & 0 & 17 & 0 & 0 & 0 & 0 & 9 & 0 \\
\hline MAO 187 & 12 & 1 & 1 & 29 & 23 & 16 & 0 & 12 & 0 & 1 & 0 & 0 & 5 & 0 \\
\hline MAO 125 & 9 & 1 & 2 & 20 & 20 & 20 & 0 & 26 & 0 & 0 & 0 & 0 & 2 & 0 \\
\hline MAO 194 & 12 & 0 & 0 & 23 & 24 & 20 & 3 & 11 & 0 & 1 & 0 & 0 & 6 & 0 \\
\hline
\end{tabular}

Legenda: $\mathrm{Z}=$ zircão. $\mathrm{T}=$ turmalina. $\mathrm{R}=$ rutilo. $\mathrm{Afs}=$ anfibólio. $\mathrm{Opx}=$ ortopiroxênio. $\mathrm{Cpx}=$ clinopiroxênios. St $=$ estaurolita. $\mathrm{Ep}=$ epídoto. $\mathrm{Sl}=$ sillimanita. $\mathrm{Ky}=$ cianita. $\mathrm{Az}=$ andaluzita. $\mathrm{Ap}=$ apatita. $\mathrm{Gt}=$ granada. Olv $=$ olivina.

Fonte: Elaborado por André G. Stern. 
Quadro 9 - Índices de minerais pesados

\begin{tabular}{|c|c|c|c|c|c|c|}
\hline \multirow{2}{*}{ Amostra } & \multirow{2}{*}{ Local } & \multicolumn{5}{|c|}{ Índices de minerais pesados } \\
\hline & & Olv & Anf + pirox & $\begin{array}{c}\mathbf{E p}+\mathbf{K y}+ \\
\mathbf{S I}+\mathbf{A z}+\mathbf{G t}\end{array}$ & Apa + Est & ZTR \\
\hline ALC 35C & Rio Içá & 0 & 0 & 16 & 15 & 69 \\
\hline ALC 36D & Sto. Antônio do Içá & 0 & 8 & 9 & 11 & 72 \\
\hline ALC 37C & Tonantins & 0 & 0 & 30 & 2 & 68 \\
\hline ALC 28A & Ravina de Tefé & 0 & 0 & 10 & 0 & 90 \\
\hline ALC 26D & Coari & 0 & 0 & 15 & 0 & 85 \\
\hline MAO 170 & Rio Içá & 0 & 68 & 24 & 0 & 8 \\
\hline MAO 175 & $\begin{array}{l}\text { Rio Solimões, } \\
\text { a montante do rio Içá }\end{array}$ & 0 & 65 & 29 & 0 & 6 \\
\hline MAO 162 & $\begin{array}{l}\text { Jutaí, no Solimões, } \\
\text { a jusante do rio Jutaí }\end{array}$ & 0 & 54 & 34 & 0 & 12 \\
\hline MAO 164 & Rio Jutaí & 0 & 71 & 22 & 0 & 7 \\
\hline MAO 179 & $\begin{array}{l}\text { Jutaí, no Solimões, } \\
\text { a montante do rio Jutaí }\end{array}$ & 0 & 73 & 20 & 2 & 5 \\
\hline MAO 154 & $\begin{array}{l}\text { Lago Uará, no Solimões, } \\
\text { a jusante do rio Jutaí }\end{array}$ & 0 & 68 & 27 & 0 & 5 \\
\hline MAO 160 & Rio Juruá & 0 & 7 & 15 & 0 & 78 \\
\hline MAO 151 & $\begin{array}{l}\text { Uarini, no Solimões, } \\
\text { a jusante do rio Japurá }\end{array}$ & 0 & 74 & 21 & 0 & 5 \\
\hline MAO 184A & Rio Japurá & 0 & 63 & 26 & 0 & 11 \\
\hline MAO 187 & $\begin{array}{l}\text { Rio Solimões na confluência } \\
\text { com o rio Japurá }\end{array}$ & 0 & 68 & 18 & 0 & 14 \\
\hline MAO 125 & Rio Purus & 0 & 60 & 28 & 0 & 12 \\
\hline MAO 194 & $\begin{array}{l}\text { Anamã, no Solimões, } \\
\text { a montante do rio Purus }\end{array}$ & 0 & 67 & 18 & 3 & 12 \\
\hline
\end{tabular}

Legenda: Olv $=$ olivina. Anf + pirox $=$ Anfibólios e piroxênios (orto e clino). $\mathrm{Ep}+\mathrm{Ky}+\mathrm{Sl}+\mathrm{Az}+\mathrm{Gt}=$ epídoto, cianita, sillimanita, andaluzita e granada. Apa + Est $=$ apatita e estaurolita. $Z T R=$ zircão, turmalina e rutilo.

Fonte: Elaborado por André G. Stern. 
Figura 29 - Fotos de lâminas dos minerais pesados representativos dos sedimentos dos terraços de Terra Firme (ALC)

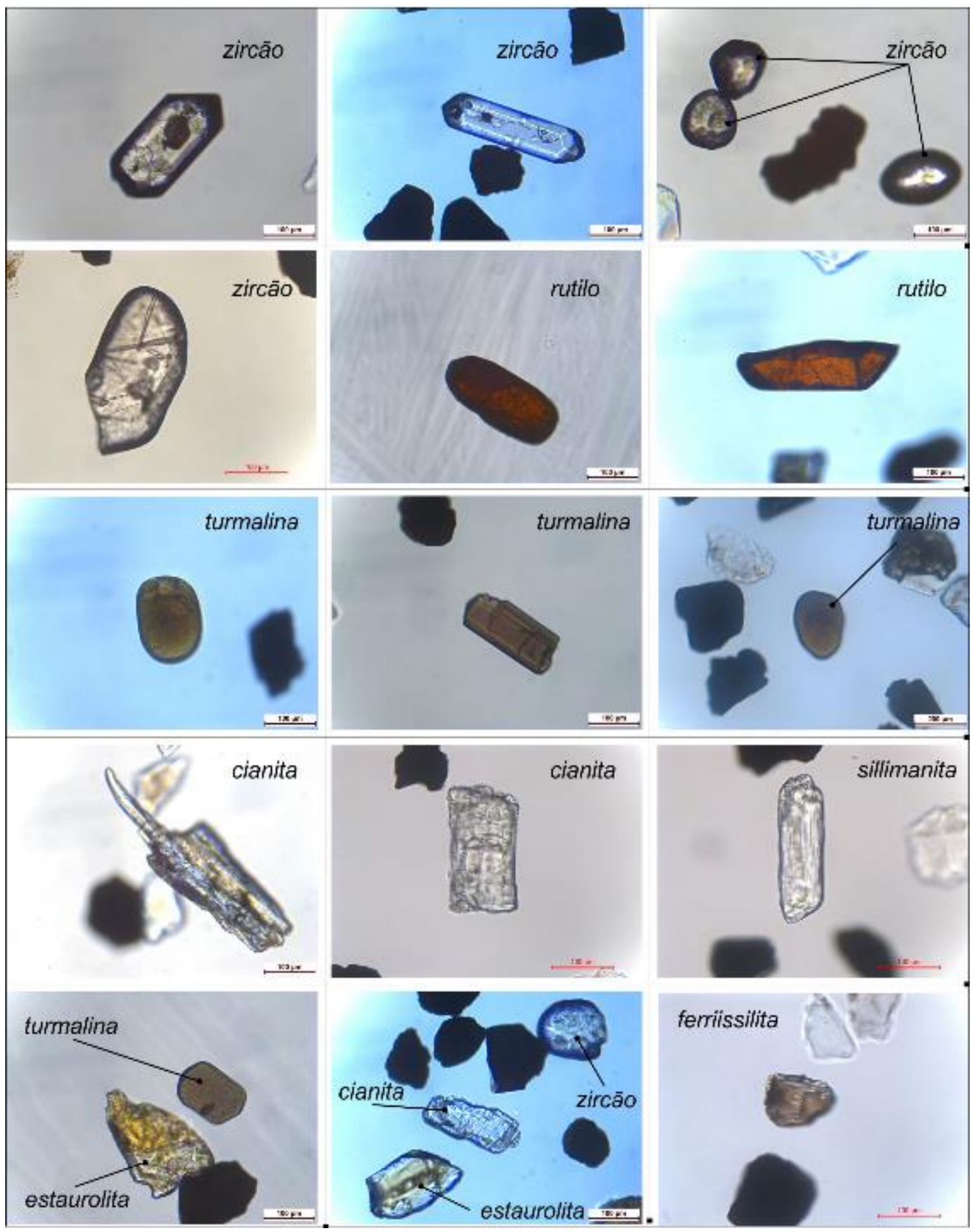

Fonte: Elaborada por André G. Stern. 
Figura 30 - Fotos de lâminas dos minerais pesados representativos dos sedimentos do leito de rios ativos (MAO)

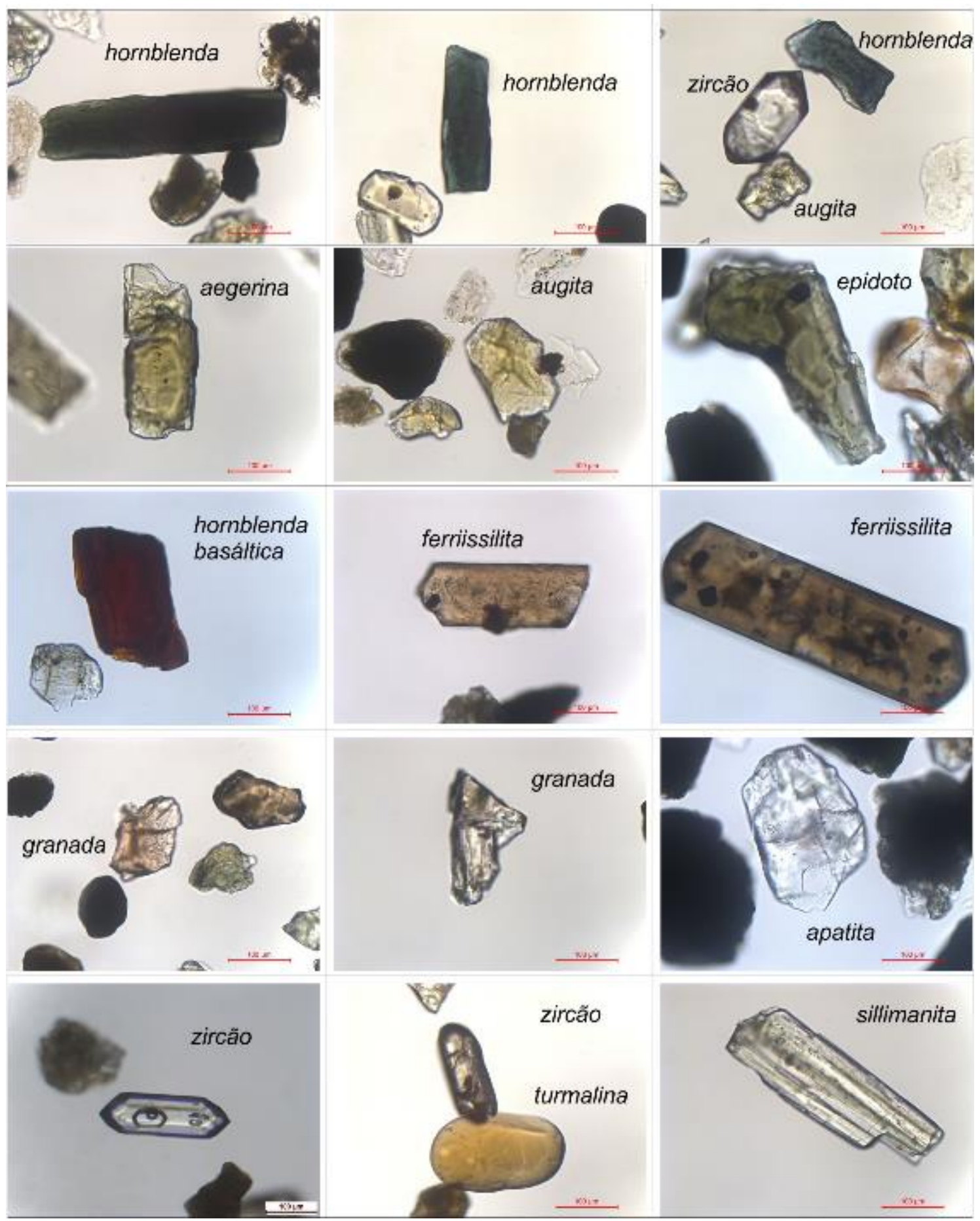

Fonte: Elaborada por André G. Stern.

Zircão é o mineral mais abundante e ocorre geralmente incolor com formas euédricas de prismas longos bi-piramidados, às vezes com bordas arredondadas. São comuns também as formas anédricas arredondadas e bem arredondadas e, mais raramente, fragmentos angulosos. Os grãos de turmalina são geralmente marrons ou esverdeados, raramente azuis ou amarelos, 
com formas anédricas arredondadas e, mais raramente, euédricas prismáticas com bordas arredondadas. Os grãos de estaurolita são geralmente anédricos, angulosos, com superfícies frescas sem alteração, com cores de amarelo claro a escuro. Os grãos de rutilo ocorrem nas cores vermelha, amarela e marrom intenso, anédricas, arredondadas e raramente euédricas prismáticas, e são comuns grãos geminados. Os grãos de cianitas são comuns, incolores límpidos e com variedades ricas em inclusões carbonosas, as formas dominantes são as prismáticas, mas ocorrem também grãos quebrados. Em geral, os grãos de sillimanitas são incolores, às vezes fibrosos, e costumam ter forma prismática.

Secundariamente, em 20 a $40 \%$ das amostras estudadas, ocorrem os seguintes minerais: andaluzita ( 0 a 15\%), anfibólio cálcico ( 0 a 8\%), granada ( 0 a 1\%) e, menos de 1\%, clinopiroxênios, ferrissilita, apatita, espinélio e gedreita. Uma assinatura mineralógica marcante das areias da são os altos valores da somatória ZTR, que variam de 68 a 92\%, com média de $77 \%$, indicando domínio de mineralogia ultraestável em detrimento dos minerais metaestáveis (Gráfico 4). Quando se compara a variação mineralógica com a distribuição geográfica das amostras, supondo-as todas de mesmo nível estratigráfico, verifica-se que a distribuição não é tão homogênea em relação ao zircão, que mostra tendência de aumento na direção leste, onde alcança valores de 68 a 70\% em Tefé e Coari, respectivamente.

As amostras coletadas no fundo do canal do Solimões e dos afluentes Içá, Jutaí, Juruá, Japurá e Purus se caracterizam por baixos volumes de opacos, variando de 15 a 49\%, com média de $12 \%$ (Gráfico 2). São relativamente homogêneas quanto à porcentagem entre minerais translúcidos, com dominância de assembleia rica em inossilicatos e minerais do grupo do epídoto, que ocorrem em praticamente em 100\% das amostras, com exceção da MAO 160, coletada no rio Juruá, que atinge $70 \%$ de zircão. Desse conjunto, o mineral mais abundante é o anfibólio cálcico que, em média, contribui com $25 \%$ do volume. Nessa categoria, incluem-se hornblendas, actinolitas e raramente tremolitas. A população majoritária e de hornblendas, que geralmente ocorrem nas cores verde e marrom, raramente avermelhada prismática (basáltica) e muitas vezes com bordas serrilhadas. Secundariamente, os piroxênios e minerais do grupo do epídoto são os mais representativos, com a presença de clinopiroxênios (augita-diopsídio, com 19\%), ortopiroxênios (ferrissilita, com 18\%) e epídoto (zoizitas, clinozoizitas e epídoto, com 19\%). 
Gráfico 1 - Minerais pesados ALC e MAO. ALC são amostras de terraços de Terra Firme. MAO, sedimentos coletados em leitos de rios ativos

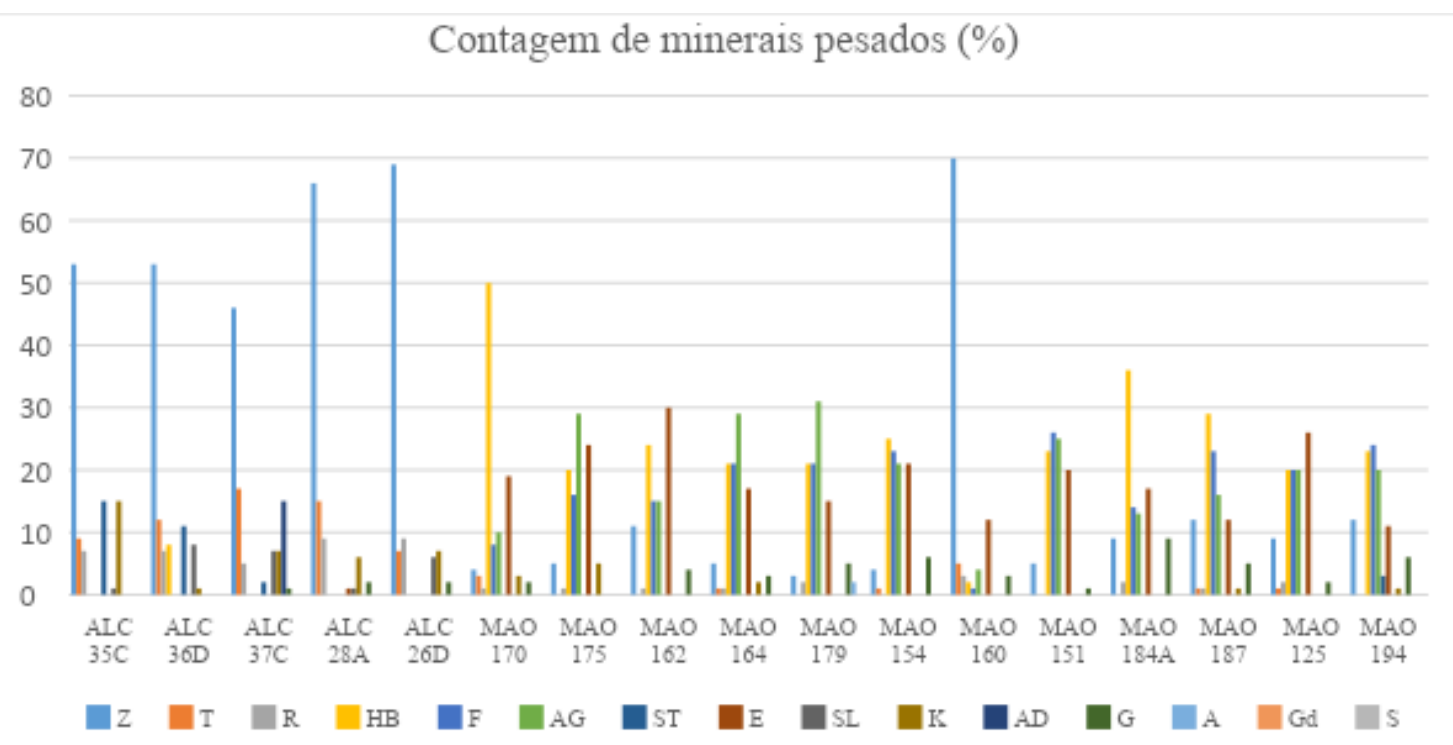

Fonte: Elaborado por André G. Stern.

Gráfico 2 - Assinatura mineralógica das amostras estudadas. A curva azul representa os sedimentos da Formação Içá (ALC), e a curva laranja, os sedimentos de rios ativos (MAO)

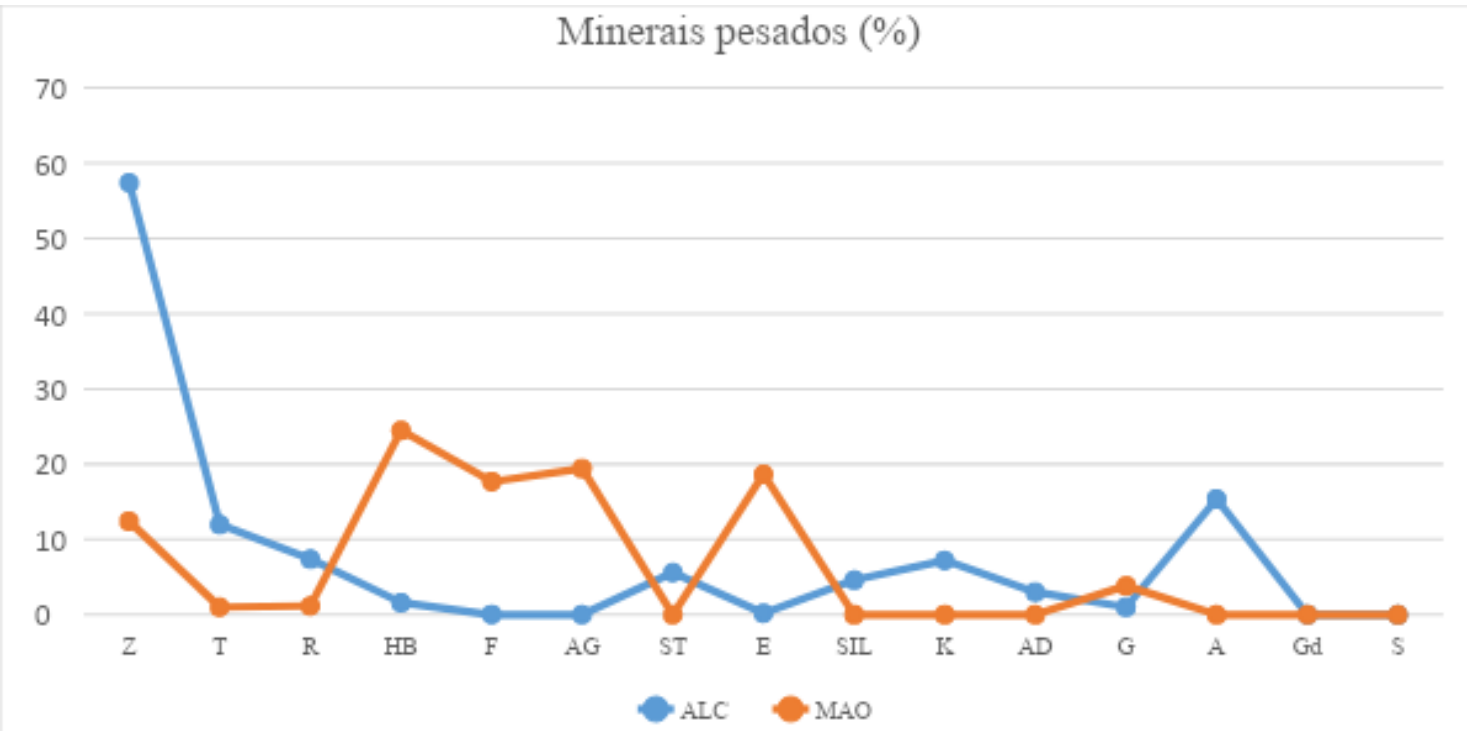

Fonte: Elaborado por André G. Stern. 
Gráfico 3 - Relação entre a presença de minerais opacos e translúcidos nas amostras estudadas. As barras azuis representam os sedimentos da Formação Içá (ALC), e as barras cor-de-laranja, os dos rios ativos (MAO)

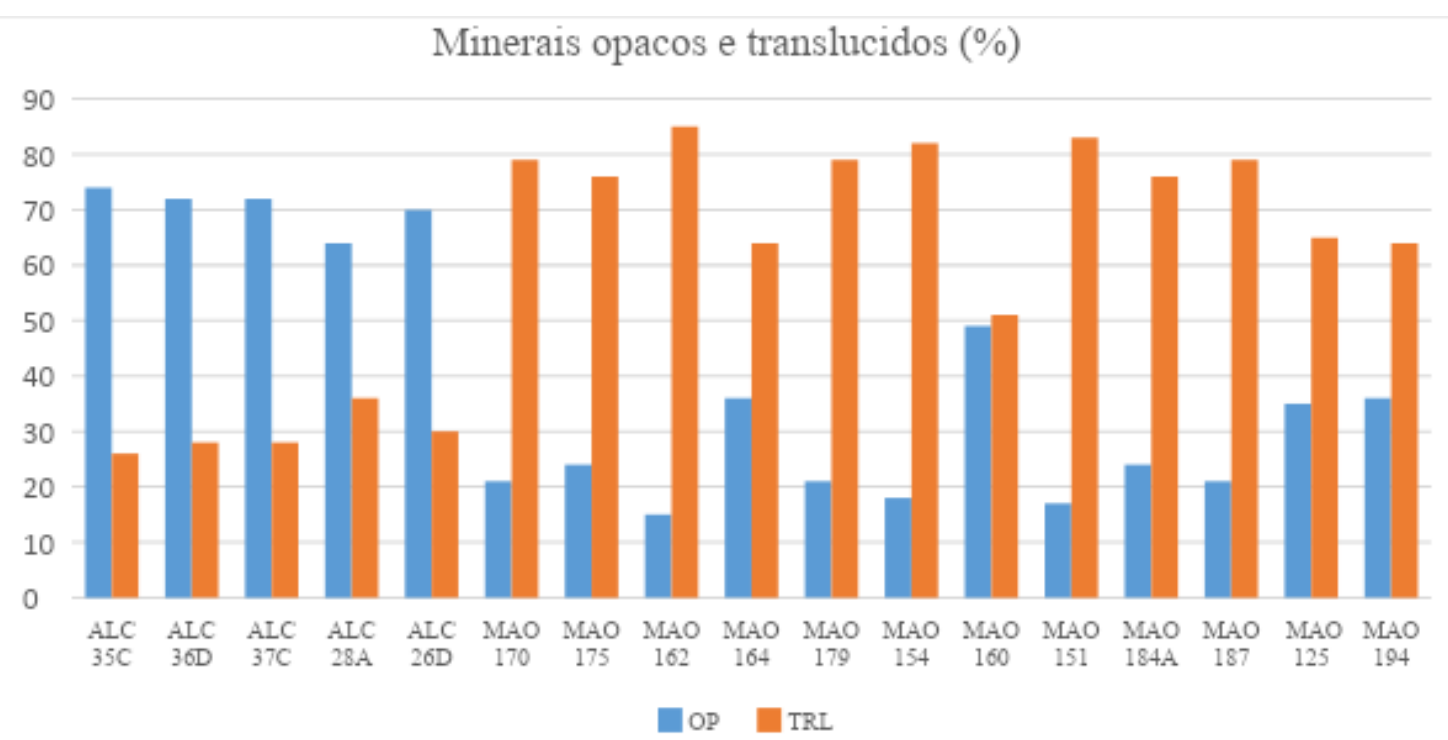

Fonte: Elaborado por André G. Stern.

Gráfico 4 - Índice ZTR (zircão, turmalina e rutilo) das amostras estudadas

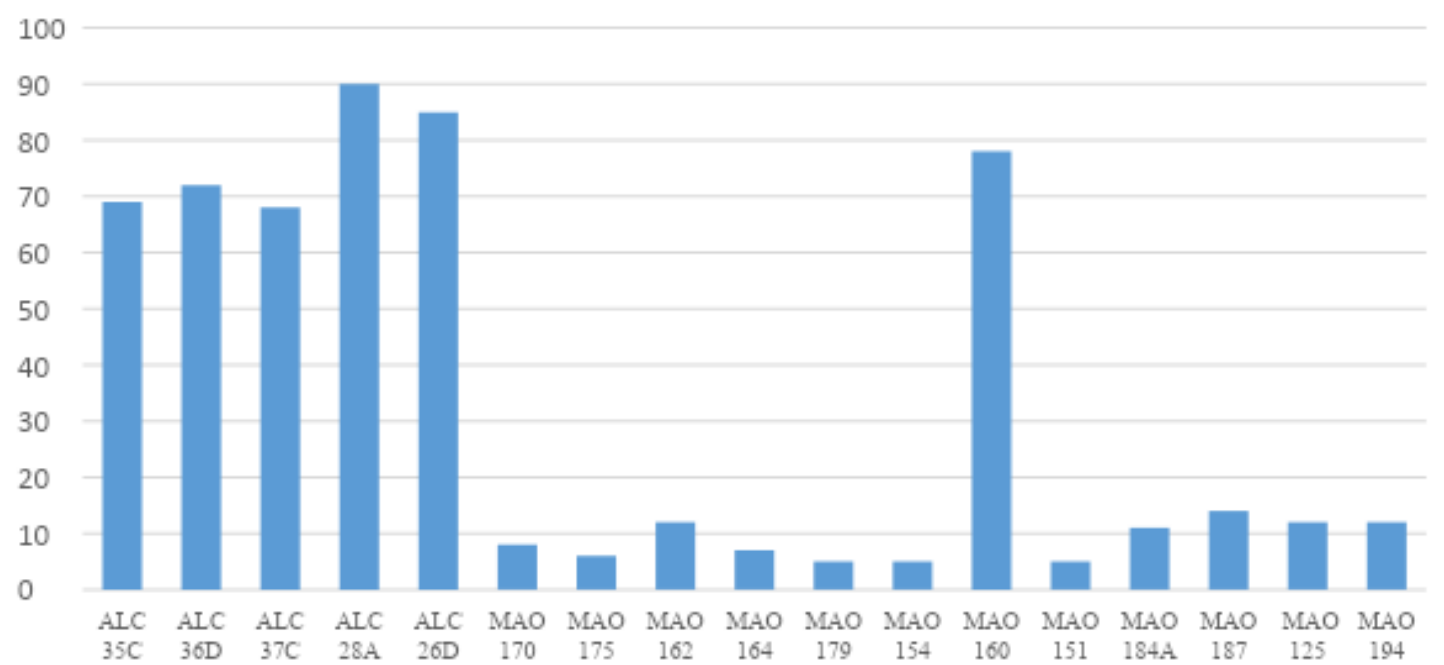

Fonte: Elaborado por André G. Stern.

Nos clinopiroxênios, as formas dominantes são prismáticas, muitas vezes com bordas serrilhadas, e as augitas predominam sobre o diopsídio. A cor das augitas varia de verde claro a amarelo e, mais raramente, apresentam-se cores fortes e pleucroicas. Nos ortopiroxênios, a ferrissilita ocorre em formas euédricas de prisma longo, geralmente sem serrilhado de borda, às vezes euédricas bem fragmentadas e angulosas. Não se observou nenhuma predominância 
do grupo do epídoto, ocorrendo de maneira semelhante às variedades zoizita, clinozoizita e epidoto, geralmente em cristal límpido ou em forma de agregado microcristalino, com domínio de formas anédricas angulosas. Subordinadamente, os minerais zircão, granada e rutilo aparecem com baixo volume em quase 100\% das amostras. Em geral, o volume do zircão é de 3 a 12\%, exceto na amostra MAO 160, onde alcança 70\%. Apresenta formas anédricas arredondadas e bem arredondadas e, mais raramente, fragmentos angulosos. Ocorrem também prismas longos bipiramidados, às vezes quebrados. As granadas $(M=4 \%)$ ocorrem sempre em formas anédricas, angulosas, incolores ou róseas. Embora presente na maioria das amostras, o rutilo ocorre em volumes de 1 a $3 \%$, com formas anédricas arredondadas ou angulosas e coloração amarela ou laranja. Com baixos valores de ocorrência, destaca-se a presença traço de minerais como turmalina, apatita, cianita e estaurolita.

\subsection{Interpretação dos dados dos minerais pesados}

A comparação entre as assembleias de minerais pesados dos terraços pleistocênicos investigados e amostras de sedimentos de fundo dos rios ativos revela que a alteração intempérica nos terraços alterou significativamente a composição das amostras. Os Gráficos 4 e 5 mostram que a exposição de sedimentos ao intemperismo aumentou, ao mesmo tempo, significativamente o índice ZTR, pela redução da proporção de minerais menos estáveis, e a proporção de opacos, como decorrência da oxidação de minerais máficos.

A integração destas análises com dados prévios (Horbe et al., 2013; Nascimento Jr. et al. (2014) (Figura 32 e Gráfico 6) obtidos em terraços análogos (pertencentes ao estágio mapeado aqui) e sedimentos de rios ativos a leste da área investigada, no rio Solimões a leste de Coari e ao longo do Madeira, permite fazer inferências importantes sobre a origem desses sistemas de terraços. A quantidade de andaluzita revelou-se o melhor discriminante entre amostras de terraços pleistocênicos coletadas a leste e a oeste da cidade de Tefé, neste e em trabalhos anteriores, nos depósitos da margem direita do rio tronco Solimões-Amazonas. A comparação desses resultados com dados então publicados recentemente sobre os sedimentos de rios ativos revela que o rio Madeira tem assinatura semelhante aos terraços a leste de Tefé, com altos teores de andaluzita (Gráfico 6), como constataram Horbe et al. (2013), que, entretanto, preferiram interpretá-los com evolução temporal da proveniência. A integração dessa informação com paleocorrentes inferidas das estruturas reliquiares no topo dos terraços 
leva à interpretação de que estes de fato compõem dois megaleques respectivamente relativos aos rios Juruá e Madeira, sendo que este último ocupou também, em seu estágio avulsivo, a área de drenagem moderna do Purus (Figura 33).

Figura 31 - Localização das amostras utilizadas na análise de proveniência por minerais pesados

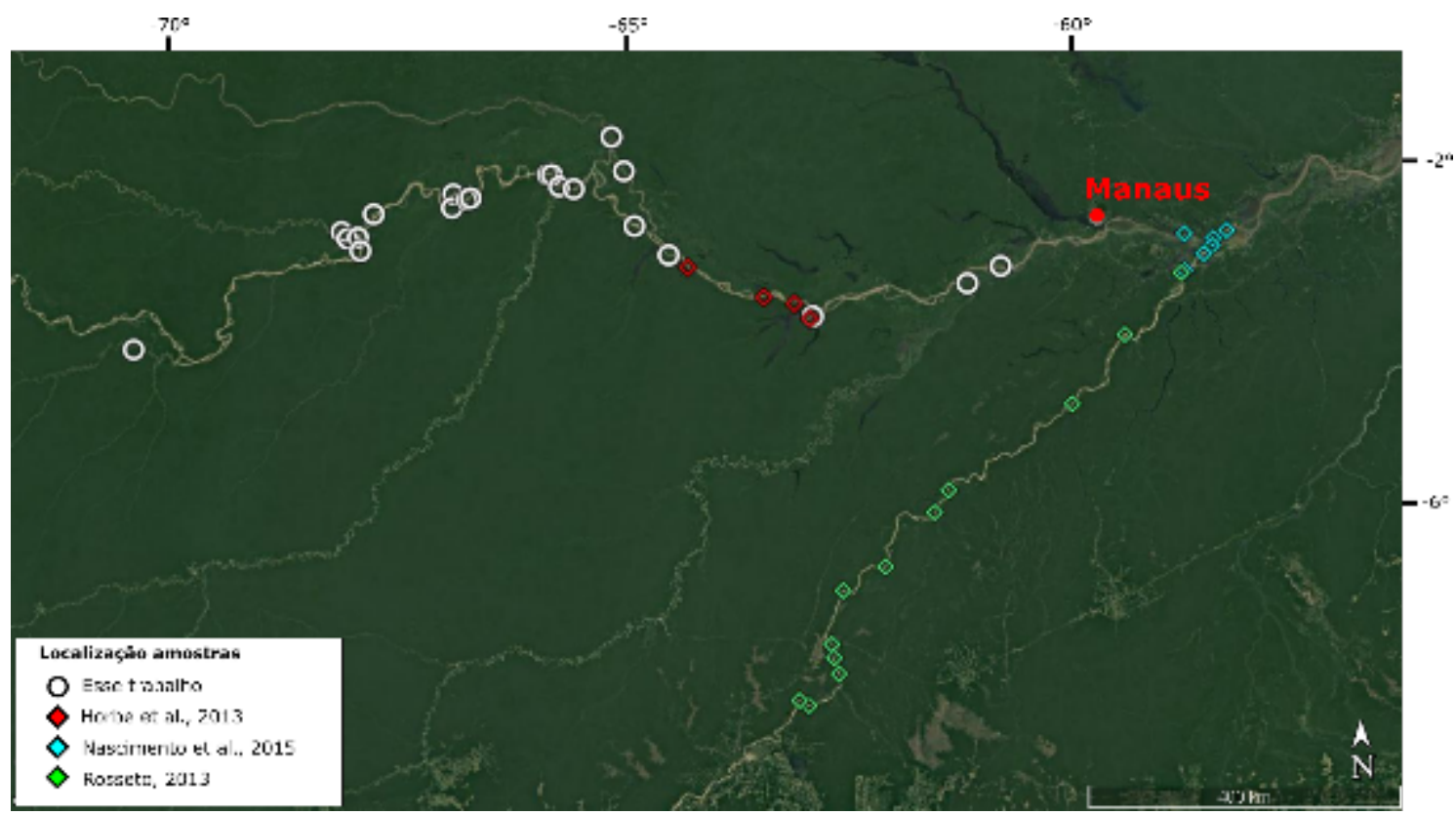

Fonte: Elaborada por André G. Stern.

Gráfico 5 - Proporção de andaluzita por índice zircão/rutilo em amostras de terraços pleistocênicos e rios ativos. Pre45_Ma_W: terraços pleistocênicos a oeste de Tefé; Pre45_Ma_Coari: terraços pleistocênicos a leste de Tefé; Andes_N: rios ativos (Içá e Japurá); Soli_W_Purus: rio ativo (Solimões a oeste da foz do Purus); Inambari: rios ativos (Juruá e Purus); Soli\&Ā_-W_Madeira: rios ativos (Solimões e Amazonas a oeste da foz do Madeira); F_Solimoes: Formação Solimões - Mioceno; Madeira: rio Madeira ativo; Am_E_Maderia: rio ativo (Amazonas a leste da foz do Madeira). Dados integrados de Horbe et al. (2013), Rosseto (2013) e Nascimento Jr. et al. (2014). Note-se que as amostras de terraços a leste de Tefé agrupam-se com as do rio Madeira, enquanto os terraços do oeste se agrupam com o Solimões e seus tributários mais ocidentais

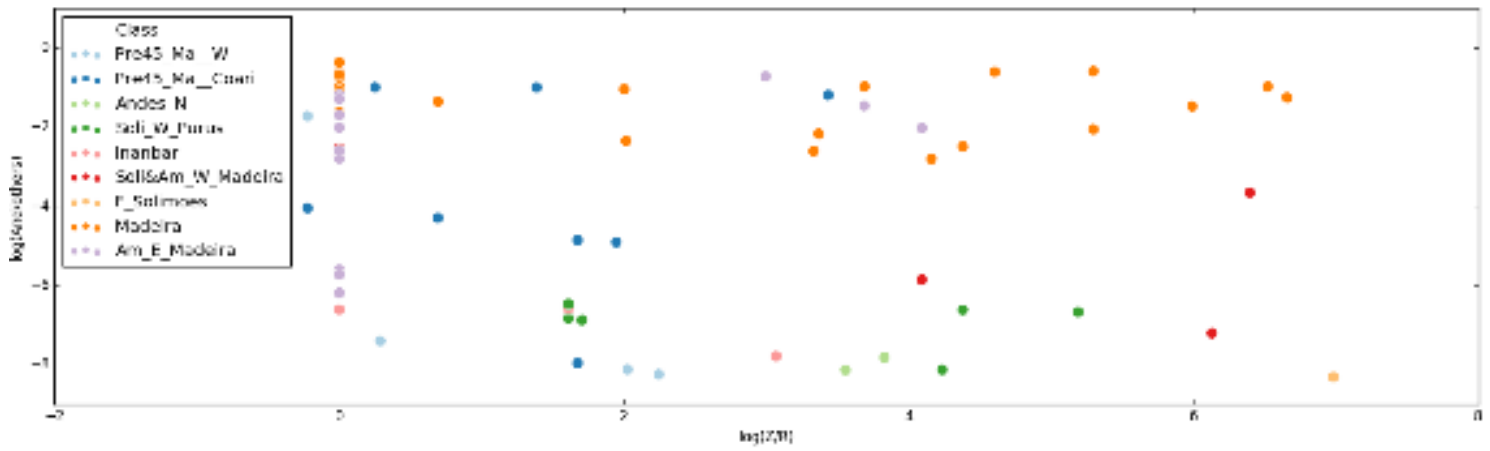

Fonte: Elaborado por André G. Stern.

Assim, os dados de proveniência e paleocorrentes sugerem que os sistemas de terraços a sul do rio tronco Solimões-Amazonas formaram-se pela coalescência de dois megalques, 
um relativo ao rio Juruá, com proveniência semelhante à do Solimões, com fontes dos Andes setentrionais, possivelmente recicladas de depósitos originais soerguidos no Alto de Fitzcarrald (Espurt et al., 2010), e outro relativo ao rio Madeira, com fontes no Andes Centrais. Terraços relativos ao próprio Solimões truncam a parte distal do megaleque do Juruá, como sugerem as paleocorrentes e a morfologia de estruturas de paleobarras, embora não sejam discrimináveis pelos dados de proveniência (Figura 33).

Figura 32 - Leques - Distinção entre os sistemas de megaleques do paleo-Madeira e do paleo-Juruá baseada nas assembleias de minerais pesados. As linhas escuras são os contornos dos níveis de terraços mapeados (ver Capítulo 4)

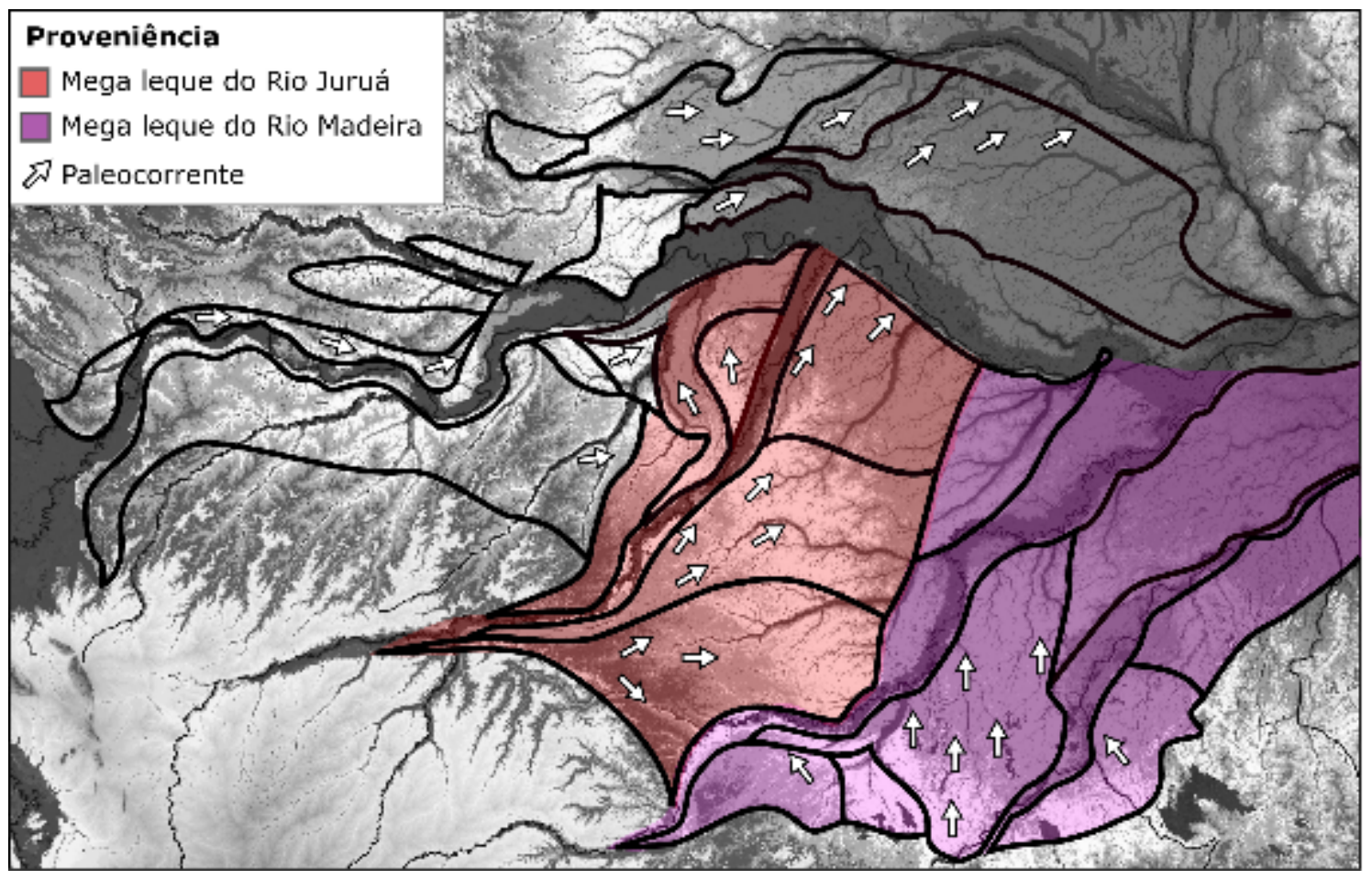

Fonte: Elaborada por André G. Stern.

\subsection{Granulometria}

As amostras da Formação Içá (ALC) apresentaram a seguinte composição média: argila $(10 \%)$, silte $(34 \%)$, areia muito fina $(15 \%)$, areia fina $(23 \%)$, areia média $(15 \%)$, areia grossa $(2 \%)$ e areia muito grossa (1\%), e as amostras das calhas dos rios (MAO) apresentaram grãos maiores, com a seguinte composição: silte (3\%), areia muito fina (4\%), areia fina (27\%), areia média (47\%), areia grossa (12\%), areia muito grossa $(5 \%)$ e grânulos não analisados pelo Malvern ( $>1 \%$ ). Pelos histogramas obtidos com os resultados da análise granulométrica das amostras, foi possível quantificar parâmetros como o grau de seleção dos 
depósitos, inferido a partir dos valores do desvio padrão, e a assimetria e a curtose, que indicam a tendência de uma fração. Assim, os sedimentos obtidos na Formação Içá (ALC) apresentam uma granulação silto-arenosa muito fina, com grau de seleção muito pobre.

Quadro 10 - Resultados estatísticos da granulometria das amostras estudadas

\begin{tabular}{cccccc}
\hline \multicolumn{3}{c}{ Sedimentos Formação Içá ALC $(\boldsymbol{\mu m})$} & \multicolumn{3}{c}{ Sedimentos leito de rio MAO $(\boldsymbol{\mu m})$} \\
\hline diâmetro médio & 5,568 & silte médio & diâmetro médio & 1,865 & areia média a fina \\
\hline desvio padrão & 2,750 & seleção muito pobre & desvio padrão & 1,078 & seleção pobre \\
\hline
\end{tabular}

Fonte: Elaborado por André G. Stern.

Gráfico 6 - Resultado da análise granulométrica de amostras de sedimentos coletadas em terraços de Terra Firme

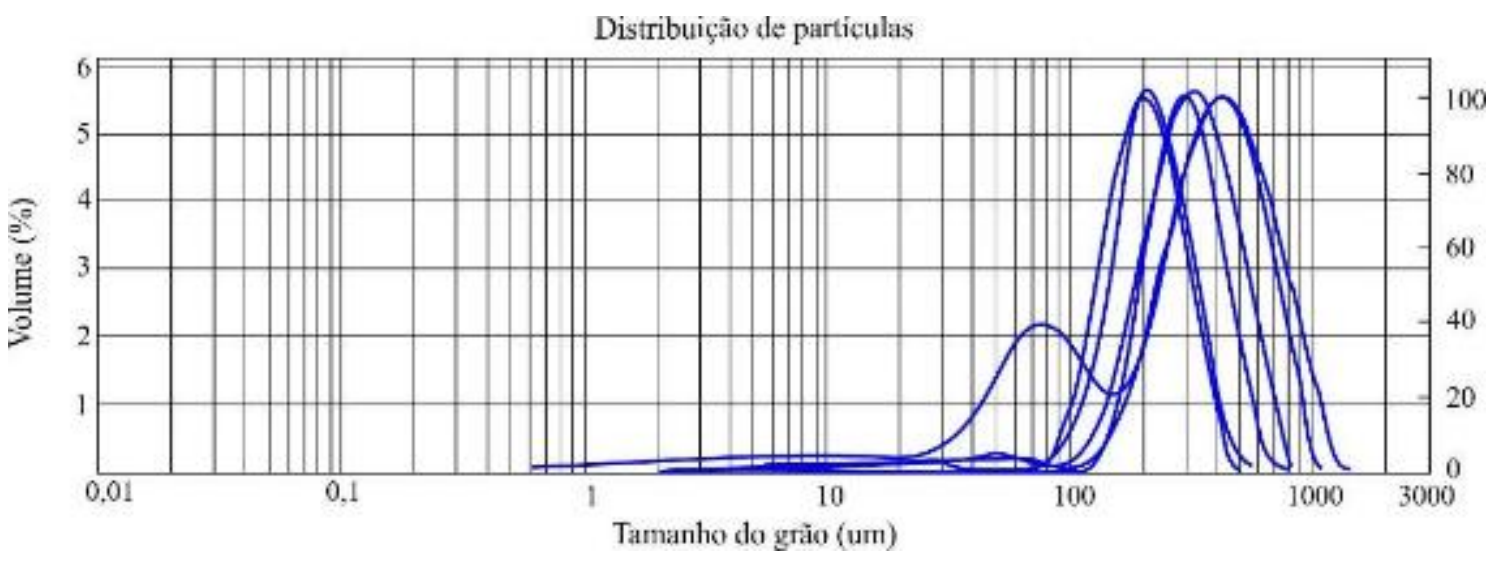

Fonte: Elaborado por André G. Stern.

Gráfico 7 - Resultado da análise granulométrica para amostras de sedimentos ativos coletadas em leitos de rio (MAO)

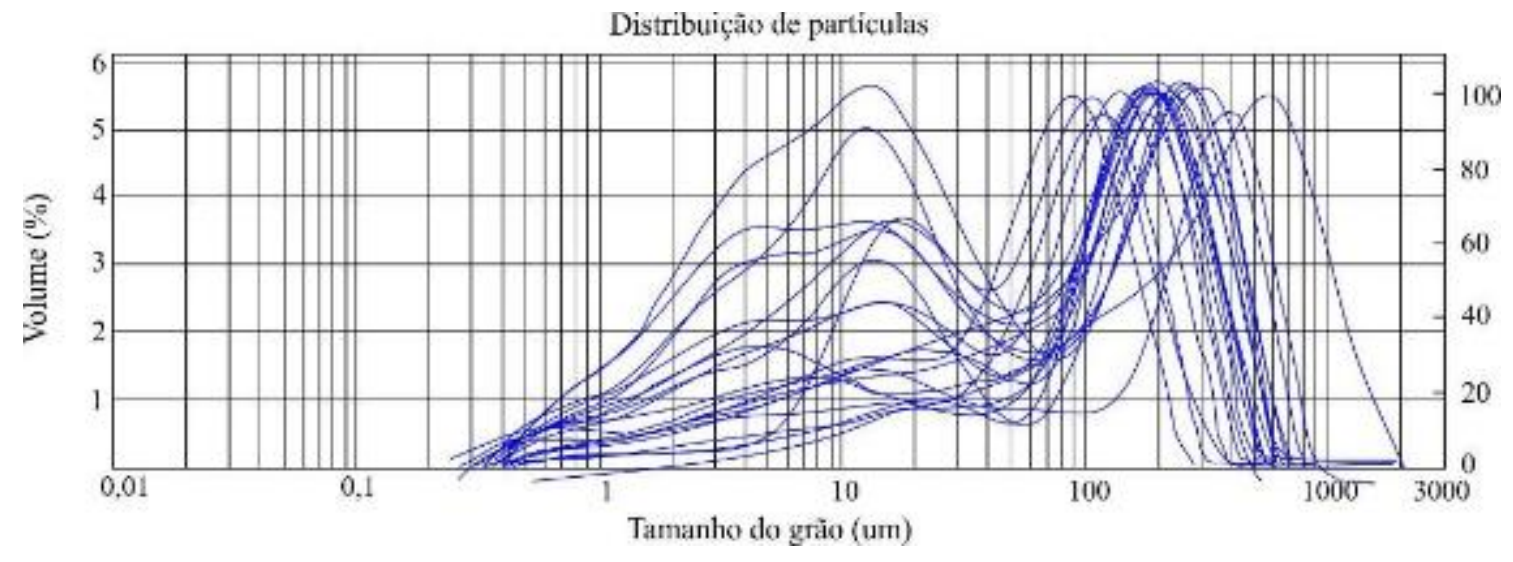

Fonte: Elaborado por André G. Stern. 
Gráfico 8 - Resultado da granulometria de sedimentos dos terraços de Terra Firme (ALC)

Distribuição de partículas - Formação Içá
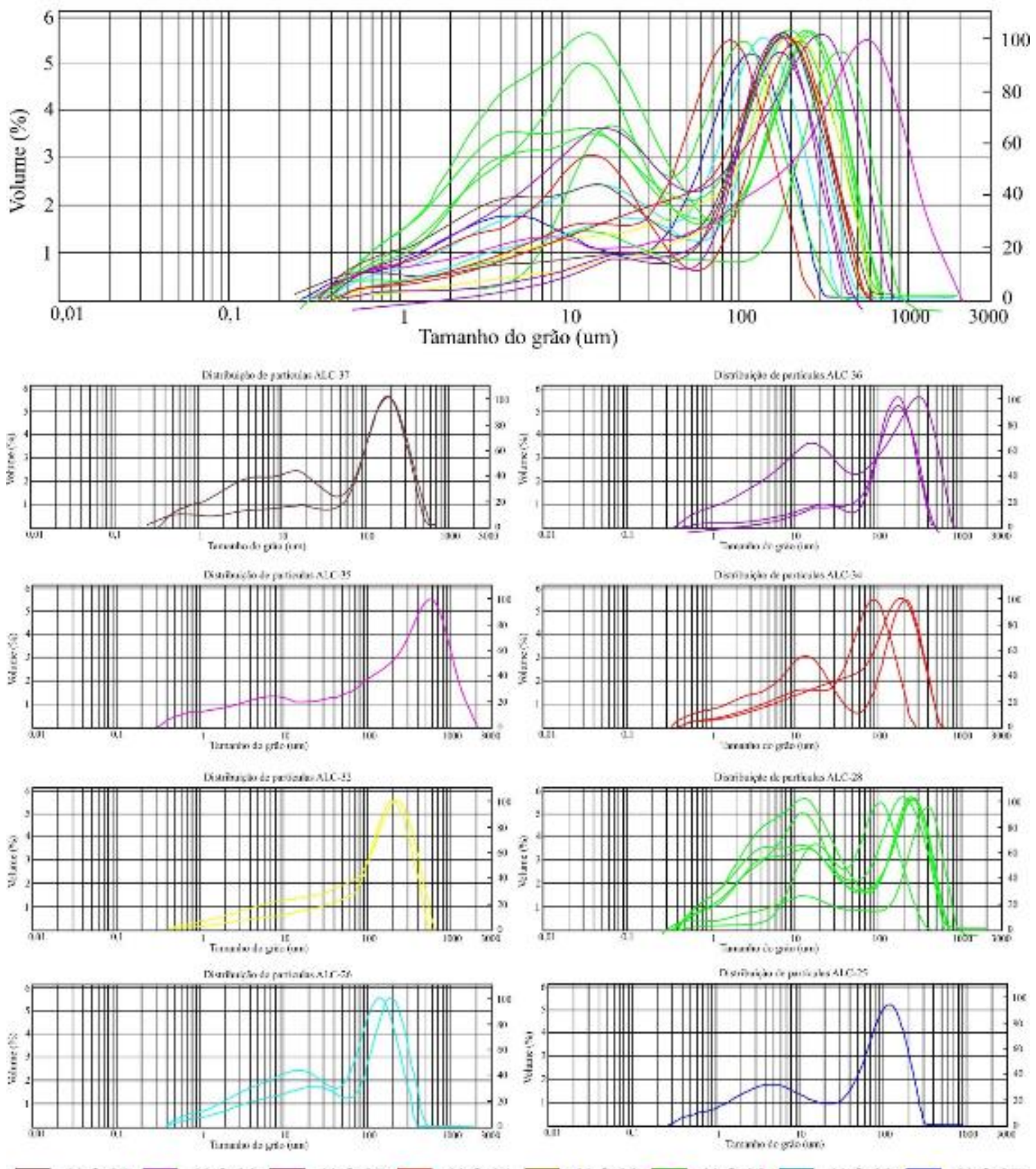

ALC-37

ALC-36 $\square$ ALC-35

ALC-34 $\square$ ALC-32 $\square$ ALC-28 $\square$ ALC-26

Fonte: Elaborado por André G. Stern. 
Gráfico 9 - Resultado da granulometria de sedimentos do leito dos rios ativos da área de estudo (MAO)
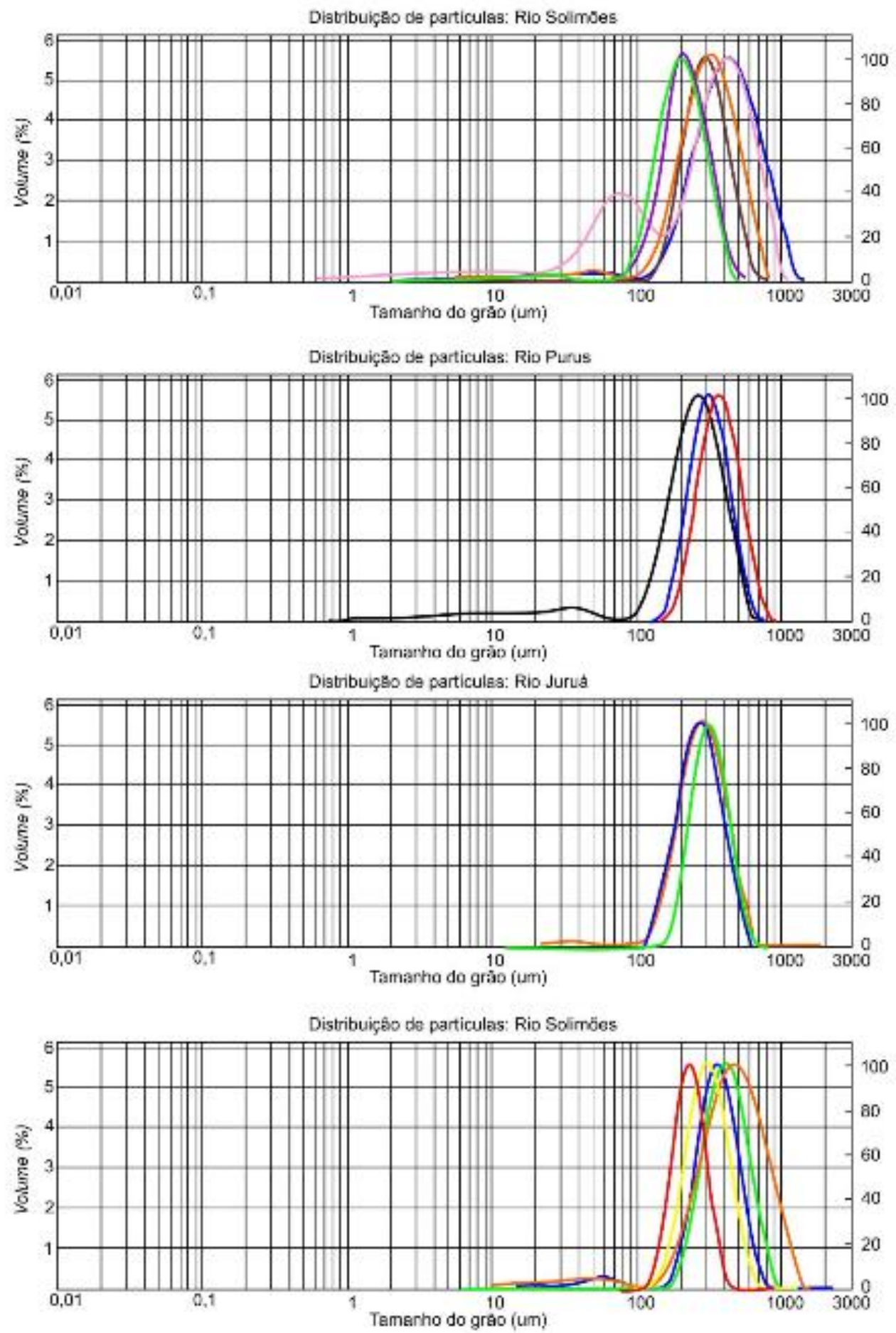

Fonte: Elaborado por André G. Stern. 
Gráfico 10 - Resultado da granulometria de sedimentos do leito de rios ativos (MAO)
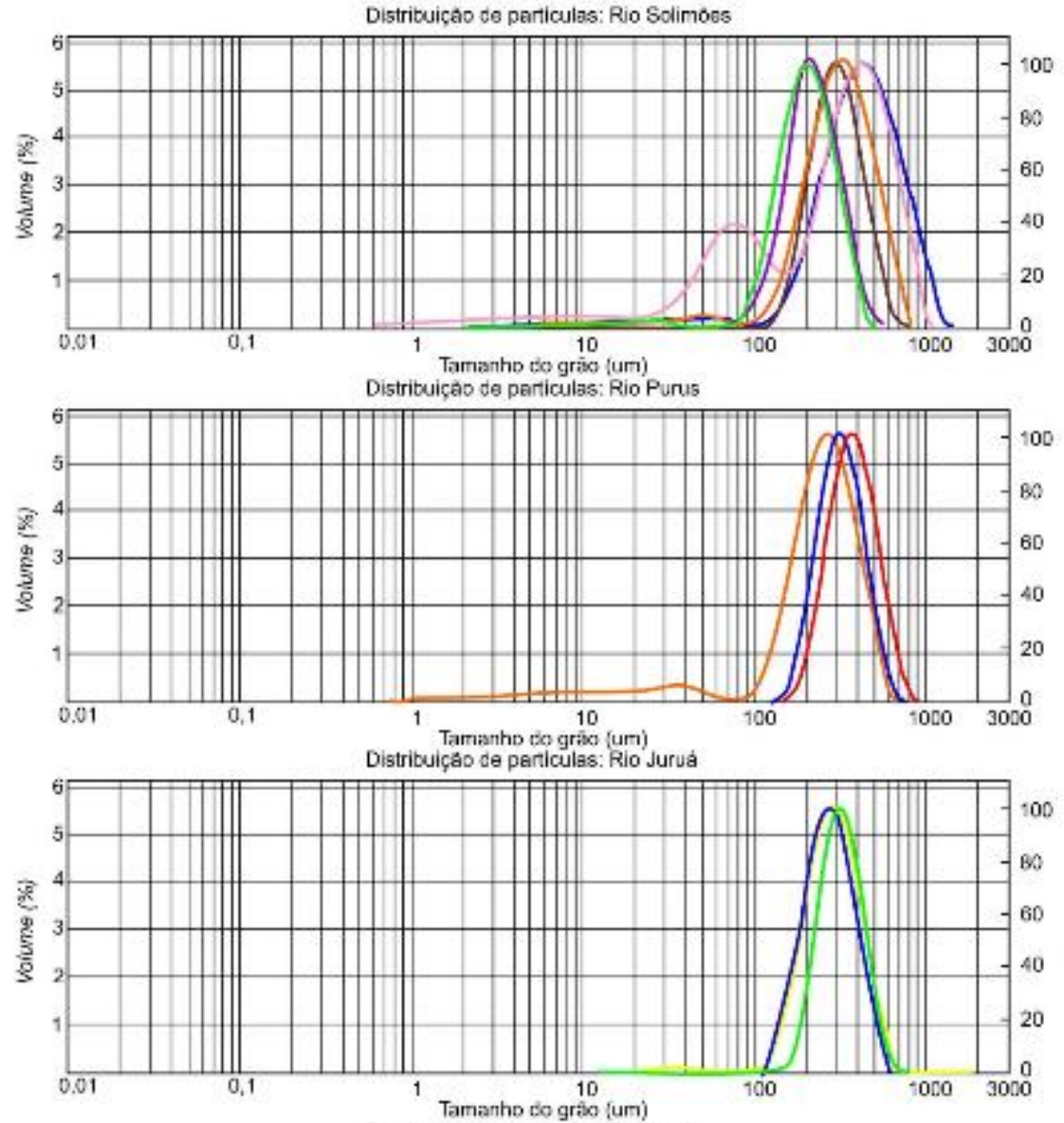

Distribuiçąo de particulas: Rio Jutai

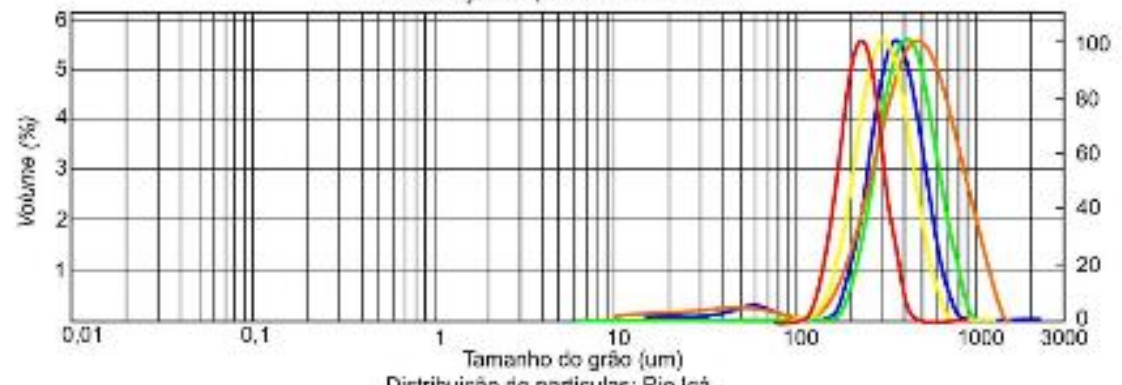

Distribuiçâo de perticulas: Rio lçá

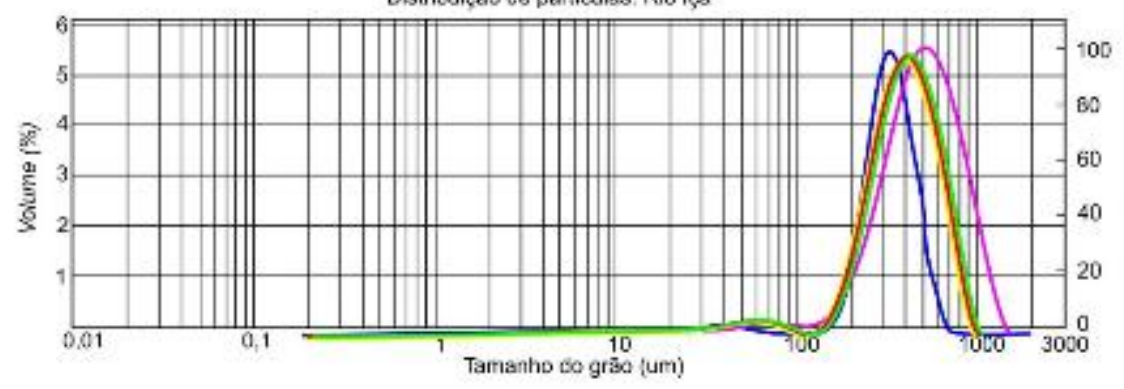

Fonte: Elaborado por André G. Stern. 


\subsection{Interpretação dos dados da granulometria}

Os dados da granulometria revelam semelhanças entre os terraços pleistocênicos e os rios ativos, com duas diferenças notáveis: as amostras dos terraços apresentam menos silte e menor granulação máxima. O segundo ponto refere-se à variação esperada em subambientes, posto que as amostras de canais ativos incluem amostragem de talvegues, onde a fração granulométrica máxima é reconhecidamente maior (Galeazzi et al., 2018). Já a menor proporção de silte pode relacionar-se ao método de seleção das amostras em afloramentos, que tiveram como objetivo primário a datação OSL, mas esse fator isolado não é uma explicação satisfatória. Processos pós-deposicionais, como a lixiviação de finos para níveis inferiores durante o intemperismo, podem ser uma contribuição adicional para essa discrepância.

\subsection{Paleocorrentes}

Medidas de orientação de estratos cruzados em afloramentos dos estágios II e III do sistema de terraços pleistocênicos permitiram reconstituir paleofluxos locais e comparar as direções de canais inferidas de paleoscrolls preservados no topo dos terraços (ver Capítulo 4). A direção média das medidas aponta um paleofluxo para NE, compatível com a interpretação de deposição em megaleques dos principais tributários da margem direita do Solimões. Diferentemente dos dados obtidos pela interpretação de direções médias de trechos nos paleoscrolls, os dados pontuais de afloramentos apresentam grande dispersão, como esperado em decorrência da sinuosidade dos canais de rios meandrantes e anabranching antigos, semelhante à dos ativos. 
Figura 33 - Paleocorrentes. Canto inferior esquerdo: sentido de fluxo médio interpretado a partir de paleoscrolls preservados no topo dos sistemas de terraços. Figura maior: rosetas de paleocorrentes e vetor médio derivados de medidas de afloramentos na área de estudo. Note-se a maior dispersão dos dados pontuais, relativa à sinuosidade dos sistemas fluviais. Número de medidas: ALC 35 - 17; ALC 37 - 17; NAM 05 - 28; ALC 32 - 15; ALC 32b - 15; ALC 28 - 86 medidas

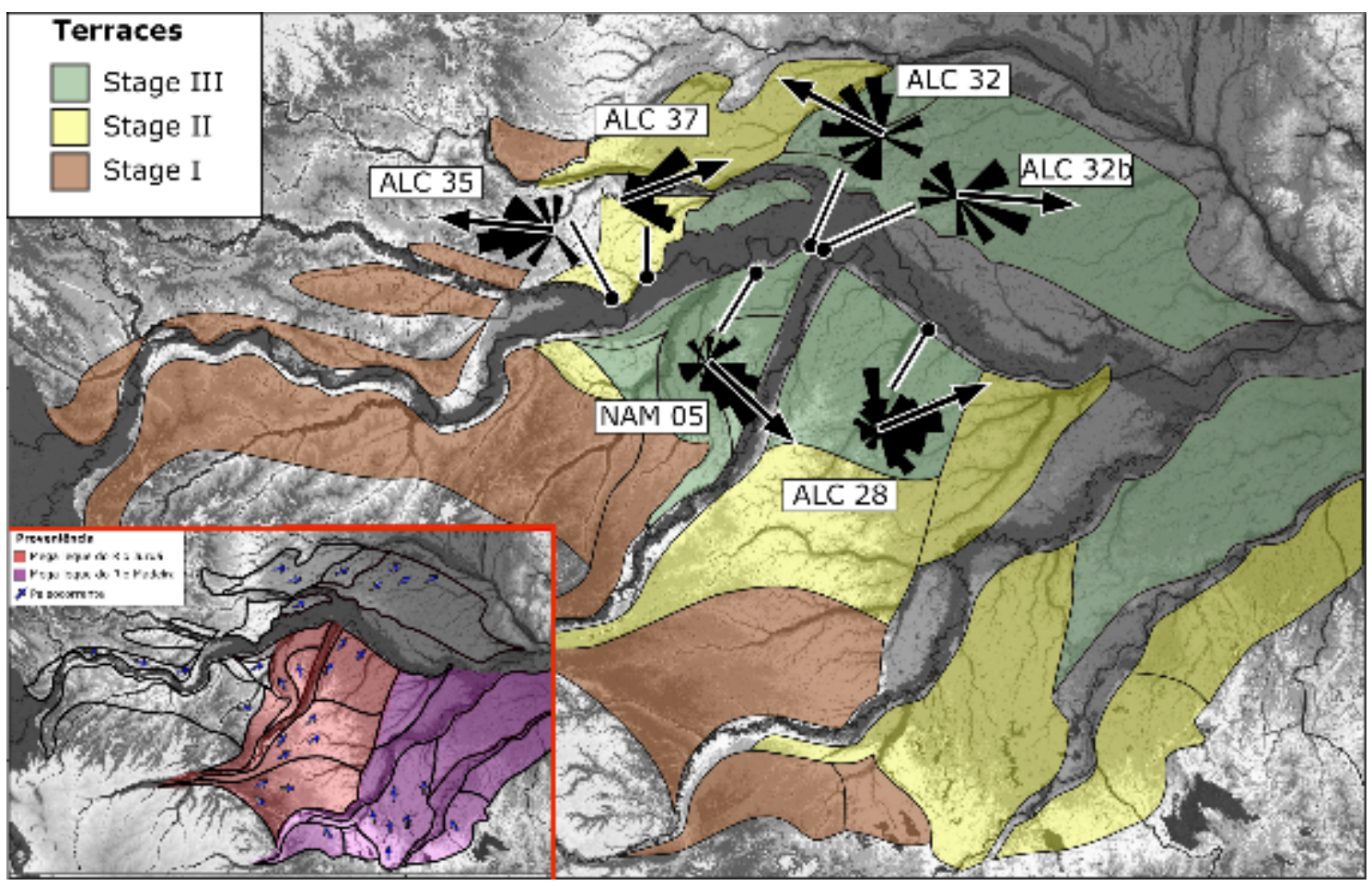

Fonte: Elaborada por André G. Stern. 


\section{A FORMAÇÃO BOA VISTA}

A Formação Boa Vista é formada principalmente por areias finas a médias, silte grosso (com grande quantidade de matriz fina, na maioria dos casos) e depósitos conglomeráticos de canais localizados. Na maior parte de sua área de ocorrência, esses depósitos recobrem camadas lateríticas bastante características (Figura 3). Na Guiana, são correlacionados, respectivamente, com a Formação Savanna do Norte e a Formação Nappi Laterita, ambas pertencentes ao Grupo Corentyne (Berrangé, 1977).

Autores brasileiros consideram que a camada laterítica e os depósitos areno-siltosos pertencem à mesma unidade, denominada Boa Vista (Barbosa; Ramos, 1959; Latrubesse; Nelson, 2001). No entanto, a camada laterítica é separada dos depósitos subjacentes por uma superfície erosiva marcante e, consequentemente, representa um hiato temporal. Assim, parece mais adequada a proposta Berrangé (1977), que considera as duas formações diferentes pertencentes ao mesmo grupo.

Neste trabalho, considera-se que tanto a camada laterítica quanto o depósito siltoarenoso pertencem à Formação Boa Vista (FBV), subdivididos informalmente numa porção laterítica denominada Formação Boa Vista inferior (FBVI) e uma silto-arenosa denominada Formação Boa Vista superior (FBVS). A FVB não apresenta bons afloramentos; as melhores exposições foram encontradas em áreas de empréstimo para a construção de estradas e em algumas margens de rios. As espessuras encontradas dessas exposições variam entre 2 e $5 \mathrm{~m}$, sendo as da FBVI sempre maiores do que as da FBVS. O contato entre as duas unidades pode ser abrupto ou gradacional, observando-se, na maioria das vezes, superfície irregular (Figura 36A), denotando uma superfície erosiva. Em alguns lugares, esse contato é marcado pela presença de espessas lentes ortoconglomeráticas localizadas na base da FBVS (Figura 3). 


\subsection{Formação Vista Boa Inferior (FBVI)}

A FBVI consiste numa camada laterítica às vezes maciça e outras composta por pisólitos e/ou nódulos ferruginosos densos. As espessuras observadas no afloramento variam de 2 e 3 m. Embora Sinha, N. (1968) descreva nove tipos de laterita na região norte do Rupununi, na área estudada foram observados quatro tipos principais:

- lateritas maciças: ocorrem frequentemente na porção inferior da FVB (Figura 36A) e são comumente superpostas por lateritas pisolíticas ou nodulares. Em vários afloramentos, nota-se a presença de um lineamento de grandes blocos de laterita próximo ao topo da FBVS, possivelmente correspondendo ao rompimento de uma antiga crosta de laterita maciça (Figura 5D). A cor é predominantemente marromavermelhada, às vezes manchada de argila branca ou de silte ocre. A textura vermiforme (tubular) é comum e, às vezes, observam-se formas estalactíticas e colunares;

- lateritas nodulares: compostas principalmente por concreções ferruginosas de formato irregular (Figura 36B), frequentemente com grãos de quartzo, e dimensões variando de menos de um centímetro a 10-15 cm. Às vezes, se encontra "matriz" quartzosa de grãos de areia e silte, além de alguns seixos e blocos de quartzo e pedaços de arenito espalhados, provavelmente herdados de rochas sedimentares da Formação Serra do Tucano.

- lateritas pisolíticas (Figura 5C): compostas de concreções ferruginosas equidimensionais, geralmente em torno de 1-2 cm. Em geral, o tamanho das concreções é uniforme, e, como nas lateritas nodulares, podem ocorrer areias e clastos de quartzo e fragmentos de arenito; e

- lateritas retrabalhadas: compostas por fragmentos angulares a subarredondados de laterita, com tamanhos variando desde seixos até blocos, às vezes misturados com seixos de quartzo. Lateritas retrabalhadas ocorrem geralmente no topo ou perto do topo da FBVI. Em alguns casos, o principal componente estrutural dos conglomerados na base da FBVS são seixos lateríticos. 
Figura 34 - (A) Afloramento da FBV em área de empréstimo em Malacacheta, a SE da cidade de Boa Vista. Observem-se o contato erosivo irregular entre a FBVI (vermelho claro) e a FBVS (linha tracejada vermelha) e a variação abrupta na espessura do quartzo wacke no topo (amarelo claro). A camada de conglomerado na base da FBVI é composta principalmente por seixos de laterita. (B) Afloramento próximo à margem do rio Tacutu, a norte da cidade de Bonfim. Observe-se o contato irregular entre o FBVI e o FBVS (linha tracejada vermelha). Lente de conglomerado composta por seixos de quartzo imbricados (Figura $36 \mathrm{~F})$. A seta vermelha indica a escala gráfica $(-7 \mathrm{~cm})$

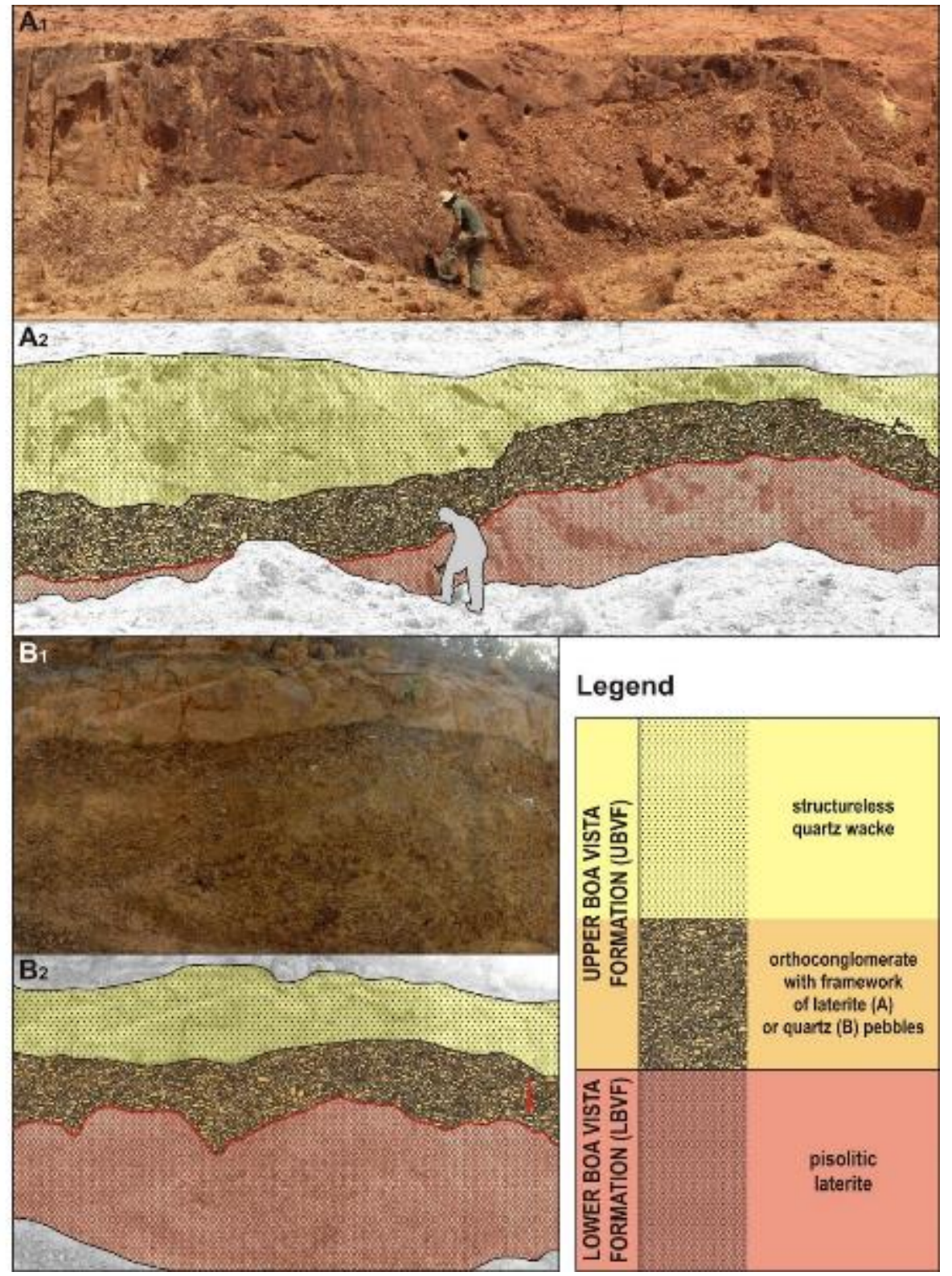

Fonte: Elaborada por André G. Stern.

Os lateritas maciças, nodulares e pisolíticas parecem corresponder à alteração in situ de rochas subjacentes. Os protólitos seriam rochas sedimentares das formações Serra do Tucano, Takutu e Apoteri (basaltos) e litologias basais pré-cambrianas. Essas rochas geralmente mostram um alto grau de intemperismo e lateritização, pelo menos parcial, e às 
vezes é muito difícil distinguir entre rochas do subsolo e a FBVI (Figuras 36A e 36G). No afloramento do rio Tacutu, a norte de Bonfim, ocorre uma camada de argila branca maciça abaixo das lateritas, que provavelmente correspondem à "argila branca untuosa" descrita por Oliveira (1929). São comuns as evidências de retrabalhamento das lateritas da FBVI, que tem contato de superfície erosiva irregular com a porção superior. Em geral, o contato com a FBVS é abrupto (Figura 5B), embora seja gradativo em algumas exposições (Figura 36E).

\subsection{Formação Boa Vista Superior (FBVS)}

A FBVS é composta por areias finas a médias e silte grossos, muito mal selecionados (Figura 37) e, na maioria das vezes, com a presença de 20 a $60 \%$ de matriz. A espessura observada em afloramentos varia de 0,5 a 3 m, e há lugares onde não há FBVI ou ela ocorre apenas como fina camada (alguns decímetros) sobre o embasamento pré-cambriano dos sedimentos e vulcânicas cretáceas do Rift do Tacutu (Figura 36G).

Não existem estruturas sedimentares nos depósitos da FBVS; em alguns lugares, o contato com a porção superior ou com o embasamento é gradativo e com grânulos, seixos e blocos provenientes de camadas inferiores configurando o desenvolvimento de uma gradação pobre. A falta de boas exposições de rocha e de estruturas sedimentares impôs grande dificuldade à descrição e à classificação de fácies sedimentares. Podem-se reconhecer estruturas de grande escala em produtos de sensoriamento remoto (Figura 38), sendo das mais notáveis uma série de lagoas rasas e depressões interligadas que, segundo Latrubesse e Nelson (2001), seriam blowout holes, ou seja, redes de drenagem lineares interpretadas como dunas eólicas lineares e duas parabólicas. A única feição certamente eólica encontrada na FBVS é o campo de dunas nas proximidades da cidade de Mucajaí (RR), situado estratigraficamente acima da FBVS (Figura 35). 
Figura 35 - Campo das Dunas de Mucajaí, a nordeste da Cidade de Mucajaí (linha tracejada em amarelo). Os números em círculos indicam amostras datadas. As linhas brancas mostram as direções predominantes do vento (unidades em porcentagem; o círculo branco corresponde a 10\%)

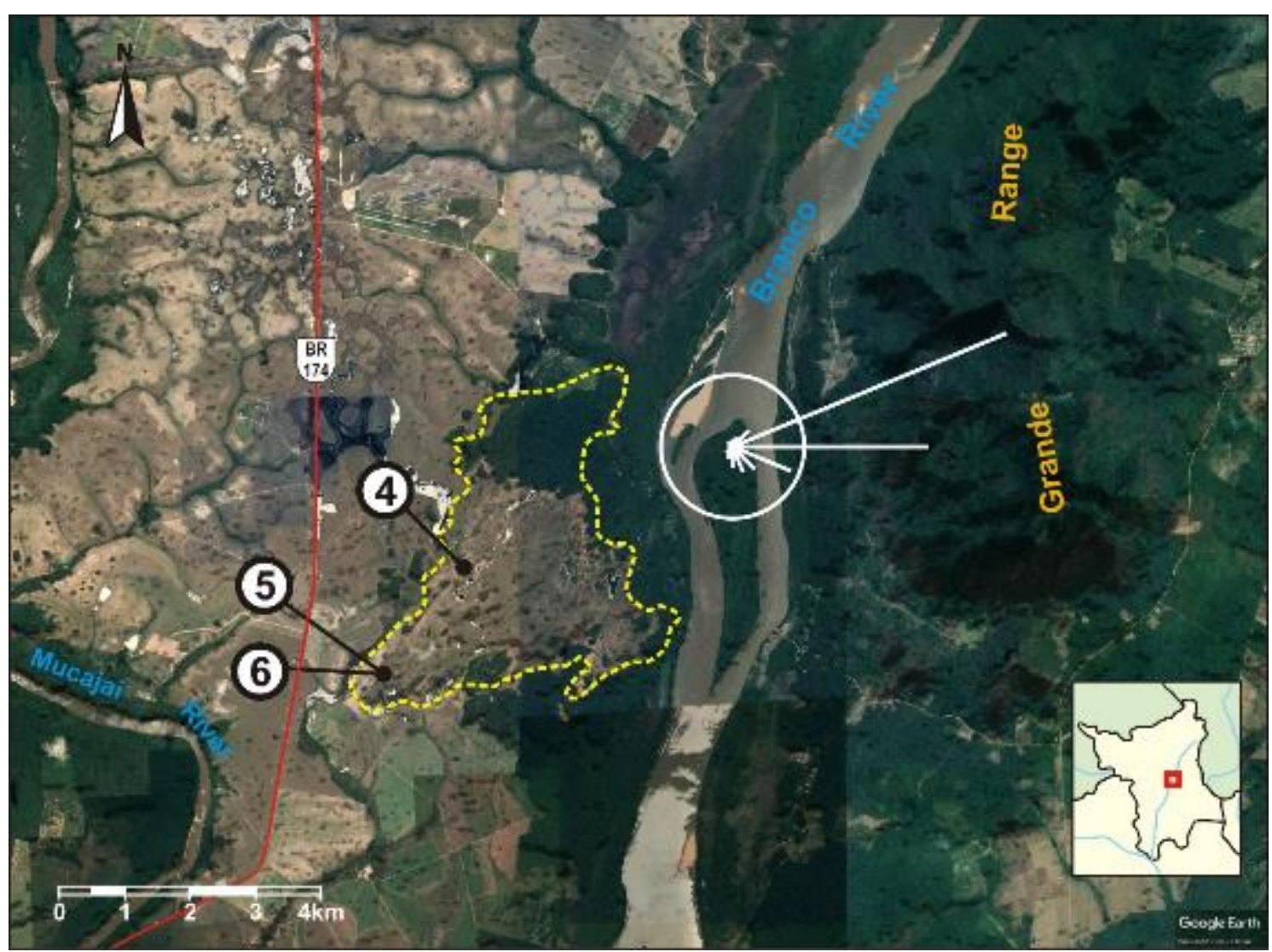

Fonte: Imagem base do Google Earth; direções do vento modificados a partir de Amarante et al. (2001). Elaborada por Marlei A. C. Chamani.

Observados em seção delgada, os sedimentos da FBVS são descritos como texturalmente imaturos, com seleção de pobre a muito pobre e grãos subangulares a angulares (Figura 36H). O mineral dominante é o quartzo (>90\%), e há subordinadamente grãos bem arredondados de óxidos de ferro. A cimentação é de ausente a ruim, e o sedimento mostra baixo grau de coesão. Quando presente, o cimento é composto de óxidos de ferro (Figura $36 \mathrm{H})$. Lentes e camadas isoladas de ortoconglomerado ocorrem em vários lugares no contato entre a FBVI e a UBVF. Compostos por seixos de quartzo (Figura 36F), quartzito e arenitos (Figura 36G), no entanto, há afloramentos em que podem predominar seixos de laterita. Os clastos são descritos como de subarredondados a bem arredondados, com tamanho entre 2 e 8 cm; costumam ser imbricados, permitindo medir a direção da paleocorrente (Figuras 36F e 36G). As características desses materiais associadas à superfície erosiva identificam a FBVI como depósito de canal fluvial. 
Figura 36 - Aspectos da FBV. (A) Laterita vermiforme maciça sobreposta a arenitos intemperizados da Formação Serra do Tucano. (B) Laterita nodular (abaixo da escala) em contato abrupto com os sedimentos ocres da FBVS. (C) Laterita pisolítica com seixos e seixos de quartzo e arenito. (D) Matacões de laterita formando uma camada descontínua, topo da FBVI. (E) Contato gradacional entre lateritas e pisolíticos da FBVI com sedimentos da FBVS. Os grânulos de laterita formam uma gradação normal pouco desenvolvida. (F) Detalhe da Figura 3B mostrando ortoconglomerado com estrutura de seixos de quartzo imbricados, correspondendo a um depósito de canal. (G) Depósito de canal na base da FBVS sobre os xistos muito intemperizados do grupo Cauarane (Paleoproterozoico).

(H) Seção fina de sedimentos da FBVS; observe-se a pobre seleção dos grãos, sendo estes de angulares a subangulares e com cimentação de óxido de ferro mal desenvolvida (manchas marrons)

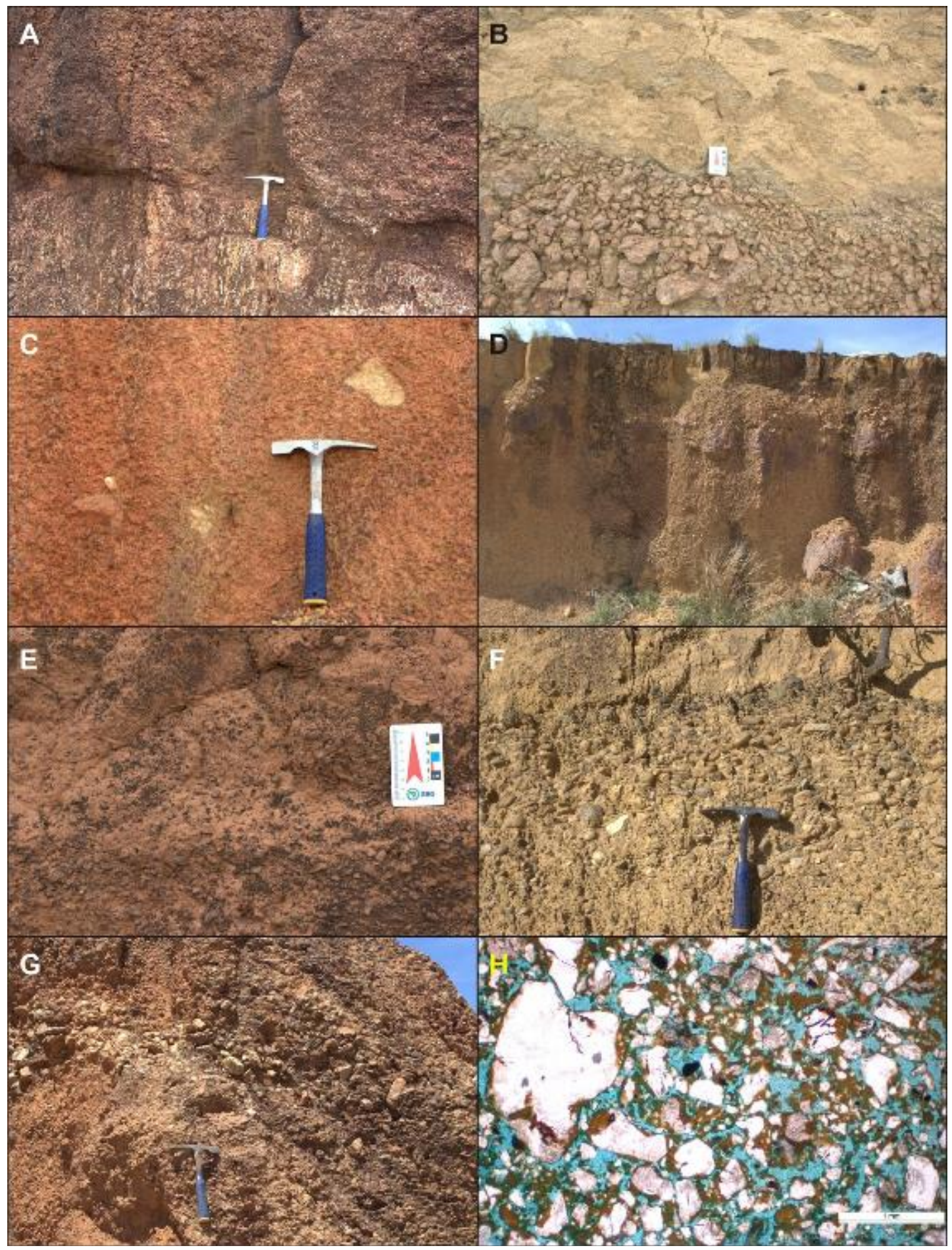

Fonte: Elaborada por André G. Stern. 


\subsection{Análise granulométrica}

A análise granulométrica quantitativa de sedimentos é muitas vezes desnecessária e de valor limitado para determinar ambientes e agentes deposicionais (Nichols, 2009; Prothero; Schwab, 2013); mas pode ser útil para determinar semelhanças e diferenças dentro de um depósito sedimentar (Lewis; McConchie, 1994). Devido à ausência de estruturas sedimentares na FBVS, a diferenciação dos depósitos foi muito difícil. Para resolver esse problema, as amostras granulométricas foram classificadas de acordo com a morfologia de sua área, como o sopé da serra de Pacaraima, áreas com blowouts holes e áreas com lineações, interpretadas como depósitos eólicos. Nenhuma dessas estruturas é observável a partir do solo, mas somente com o auxílio de um produto de sensoriamento remoto.

Gráfico 11 - Curvas de frequência (linhas escuras) e de frequência cumulativa (linhas claras) de granulometria em 18 amostras da FBVS. Linhas vermelhas: amostras da base da serra de Pacaraima. Linhas azuis: amostras das áreas com blowout holes. Linhas amarelas: amostras de depósitos eólicos
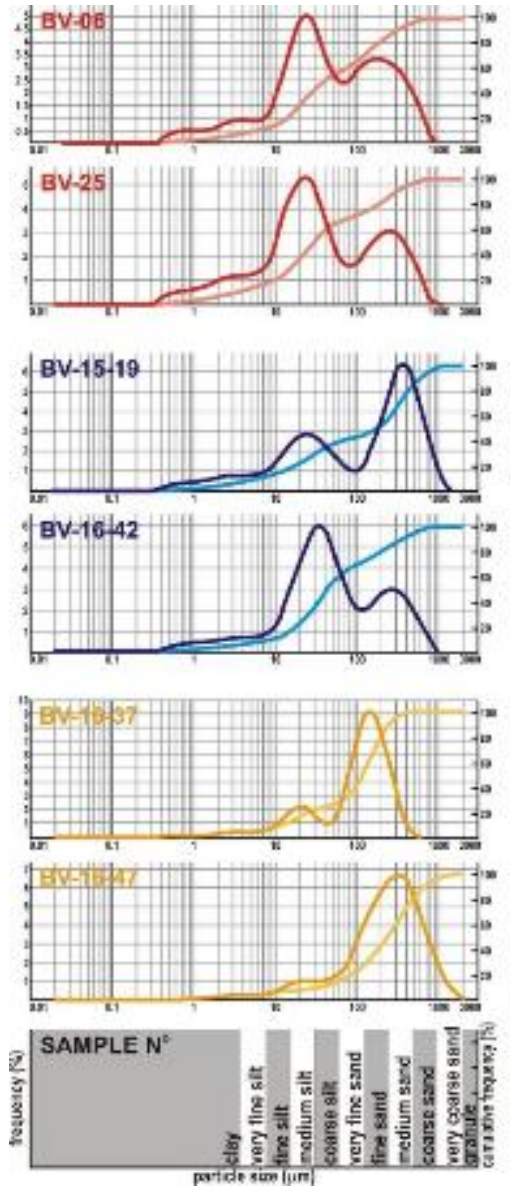
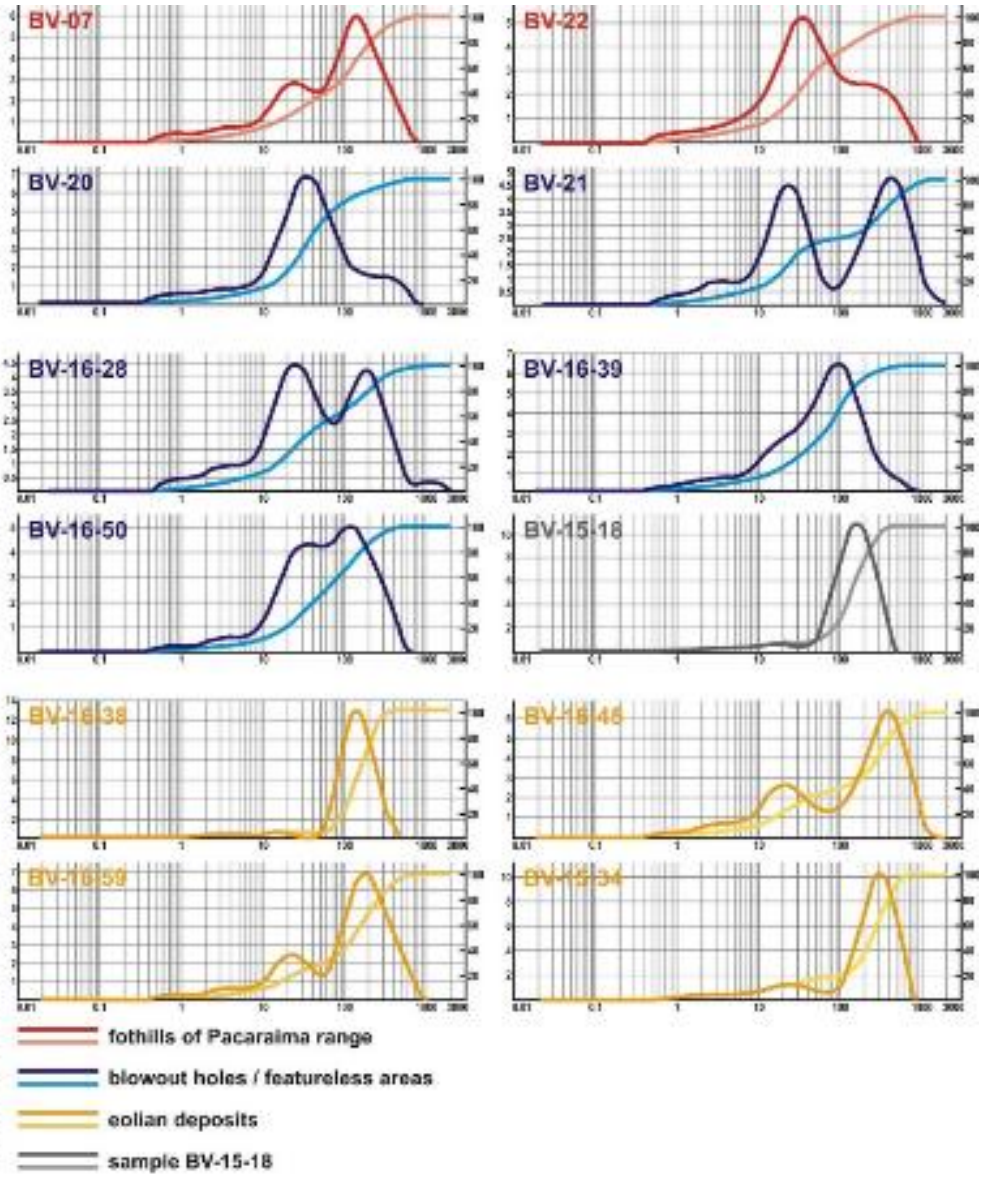
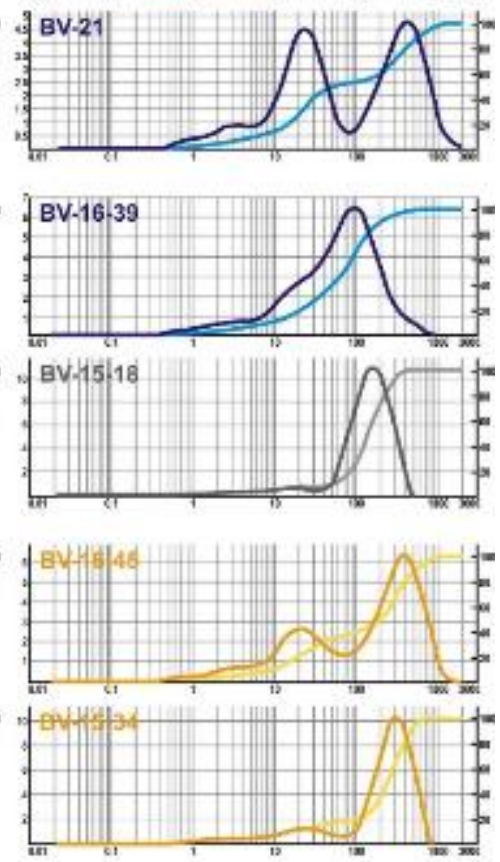

Fonte: Elaborado por Marlei A. C. Chamani. 
Os resultados obtidos permitem uma caracterização geral da FBVS com base em parâmetros granulométricos. Seleção: os sedimentos pertencentes à FBVS apresentam uma seleção muito pobre (Folk; Ward, 1957), com valores superiores a 1,99 phi. A seleção está fortemente correlacionada $(\rho=0,78)$ ao diâmetro médio - quanto menor é o diâmetro, pior é a qualificação da seleção (Figura 36). Assimetria: todas as amostras analisadas apresentaram uma forte assimetria (Prothero; Schwab, 2013), com valores variando entre 0,31 e 1,9. Curtose: a maioria das amostras apresentou uma curtose de leva a fortemente platicúrtica; cinco amostras apresentam leptocúrtica de leve a moderada, com valores distribuídos entre 0,798 e 2,514, com média de 1,20. Matriz de grão fino $(<30 \mu \mathrm{m}): 14$ amostras apresentaram quantidades matriz-fino que variam entre 23,16 e 50,37\% (Tabela 15). Assim, como regra, os depósitos da FBVS podem ser classificados como quartzo wacke de granulação fina (Dott, 1964).

Gráfico 12 - Correlação entre desvio padrão e diâmetro médio em unidades phi em 18 amostras da FBVS, mostrando uma seleção muito pobre e uma forte correlação entre o diâmetro médio e a seleção.

Os códigos de cores dos pontos individuais são os mesmos usados na anterior

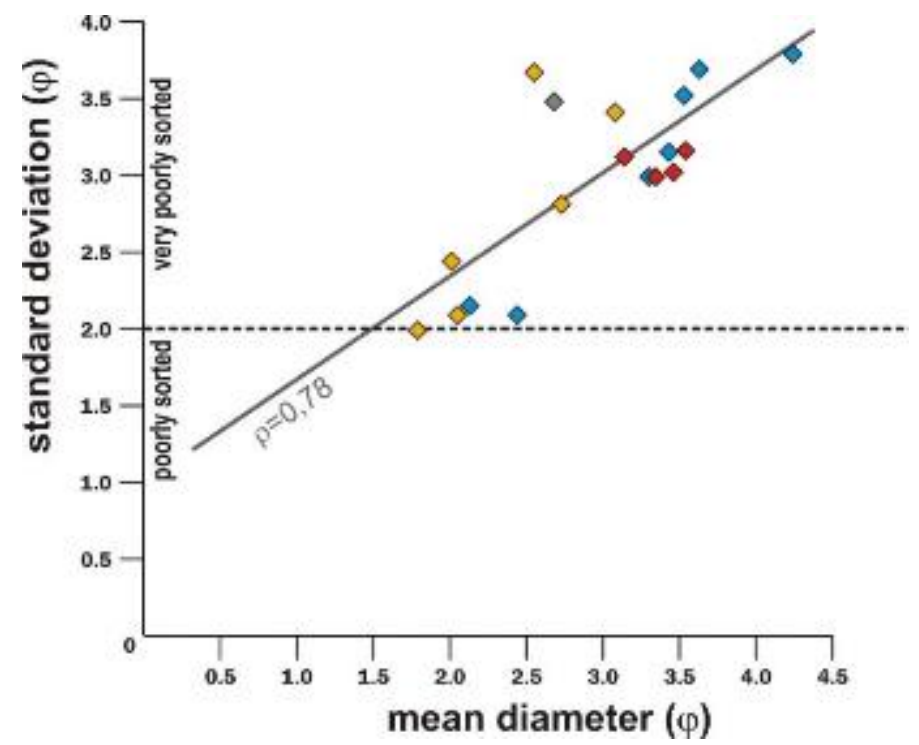

Fonte: Classificações de acordo com Folk e Ward (1957). Elaborado por Marlei A. C. Chamani

Para determinar as assinaturas granulométricas das diferentes feições da superfície, as amostras foram divididas em três grupos, de acordo com sua localização (Figura 8):

(1) base da serra de Pacaraima;

(2) áreas com blowout holes (Latrubesse; Nelson, 2001) e áreas sem feições;

(3) áreas com características identificadas como tendo origem eólica (Sinha, N., 1968; Latrubesse; Nelson, 2001; Teeuw; Rhodes, 2004; Zular et al., 2019). 
Figura 37 - Curvas de frequência granulométrica em 18 amostras da FBVS, analisadas num mosaico de imagens de satélite do Google Earth na porção nordeste do estado de Roraima e adjacente à

República da Guiana. Linhas vermelhas: amostras do sopé da serra de Pacaraima. Curvas azuis: amostras de áreas blowout holes (linhas tracejadas em rosa claro, modificadas de Latrubesse e Nelson [2001]) e áreas sem características. Curvas amarelas: amostras de áreas identificadas como depósitos eólicos (linhas tracejadas em amarelo claro, modificadas de Latrubesse e Nelson [2001] e Teeuw e Rhodes [2004]). Amostras de depósitos eólicos têm outra assinatura granulométrica. Embora numa área sem características lineares, a amostra BV-15-18 (cinza) mostra uma assinatura muito semelhante. Também está incluída a amostra das dunas de Mucajaí (BV-15-34, porção inferior esquerda), $70 \mathrm{~km}$ a sudoeste da área ilustrada

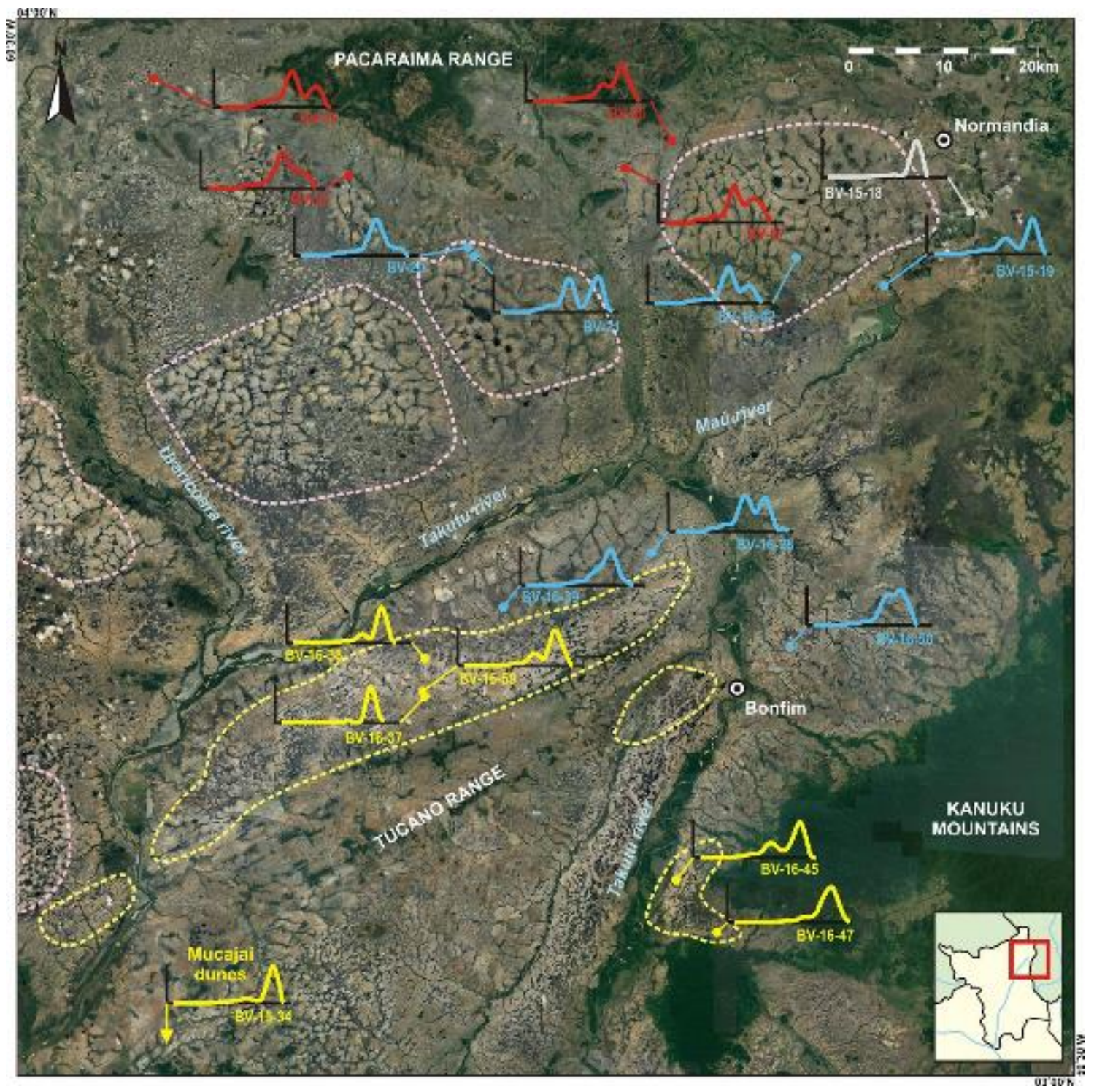

Fonte: Elaborada por Marlei A. C. Chamani.

Amostras do sopé da serra de Pacaraima mostram um padrão bastante consistente, com distribuição bimodal (Figuras 6 e 8), e a principal concentração correspondente a sedimentos de granulação mais fina (silte médio a grosso). Os diâmetros médios são relativamente pequenos (91-144 $\mu \mathrm{m}$, areia muito fina) e o conteúdo da matriz é alto (39- 
50\%), bem como os valores de assimetria (Quadro 1 e Figura 9). Amostras de áreas com blowout holes e áreas sem característica mostram um alto grau de variação, com distribuições predominantemente bimodais, embora também ocorram distribuições unimodais (Figuras 6 e 8). O diâmetro médio varia entre 53-228 $\mu \mathrm{m}$ (silte grosso a areia fina), e os valores de assimetria também variam bastante; no entanto, o conteúdo da matriz é consistentemente alto ( 36-46\%) (Quadro 1 e Figura 9). Algumas amostras mostram padrão semelhante ao do sopé da serra de Pacaraima, e não há diferença entre amostras de áreas com blowout holes e áreas sem características.

Amostras de áreas com características eólicas apresentam uma assinatura claramente distinta. As curvas de frequência mostram distribuição unimodal ou bimodal, com concentração máxima definida na faixa de areia fina a média (Figuras 6 e 8). O diâmetro médio é maior, entre 118 a $288 \mu \mathrm{m}$ (areia muito fina a areia média). Os valores de assimetria são consistentemente mais baixos, e o conteúdo da matriz é menor nessas amostras do que em qualquer outra analisada (a única exceção é a BV-15-18, discutida a seguir), com valores entre 4-29\% (Figura 39); são as únicas amostras com quantidades de matriz fina suficientemente baixas ( 4-14\%) para qualificá-las com quartzo arenitos (Dott, 1964); são três amostras de depósitos eólicos e a amostra BV-15-18.

Embora situada numa área sem característica, próxima ao rio Maú, a amostra BV-1518 mostra uma assinatura surpreendentemente semelhante às amostras de depósitos eólicos, com distribuição unodal (Gráfico 11 e Figura 38, curvas em cinza), diâmetro médio de $155.564 \mu \mathrm{m}$ (areia fina), valor de assimetria relativamente baixo e com o conteúdo de matriz em 7,73\%, o segundo menor valor entre as amostras analisadas (Quadro 1 e Figura 9). Assim, a amostra BV-15-18 provavelmente corresponde a um depósito eólico isolado. 
Gráfico 13- Histogramas de parâmetros estatísticos e sedimentares de 18 amostras da FBVS. (A) Diâmetro médio $(\mu \mathrm{m})$. (B) Conteúdo da matriz de granulação fina $(<30 \mu \mathrm{m})(\%)$. (C) Assimetria. Barras vermelhas: amostras do sopé da serra de Pacaraima. Barras azuis: amostras de áreas com blowout holes e áreas sem características. Barras amarelas: amostras de depósitos eólicos. O último mostra uma assinatura claramente distinta; a amostra BV-15-18 (barra cinza) é muito semelhante e provavelmente também é um depósito eólico

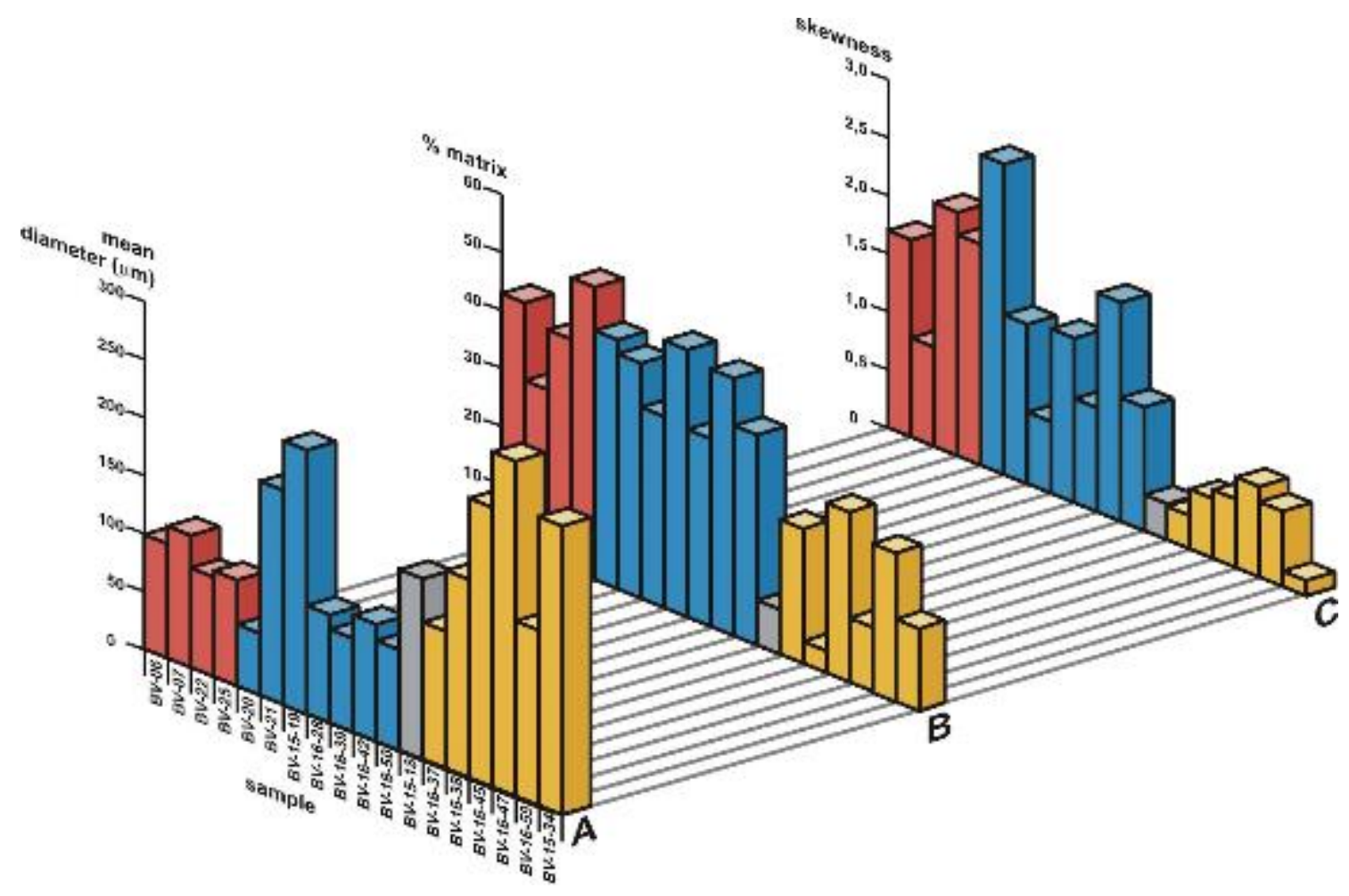

Fonte: Elaborado por Marlei A. C. Chamani.

\subsection{Paleocorrentes}

Como mencionado acima, os depósitos de paleocanais ocorrem em pontos isolados na base da FBVS (Figura 33). A imbricação de seixos (Figura 37F) permitiu medir as direções de paleocorrente em dois pontos da área estudada, um próximo ao rio Tacutu, a norte de Bonfim, e outro numa ocorrência isolada da BVF, a norte do rio Uraricoera (Figura 36). As medidas obtidas foram tratadas com o software livre Openstereo (Grohmann; Campanha; Soares Jr., 2011). Os resultados são mostrados na Figura 39. 
Figura 38 - Diagramas de rosas da direção de paleocorrentes em depósitos de paleocanais na base da FBVS. (A) Ocorrência isolada da FBV, a norte do rio Uraricoera (Figura 37-G). (B) Afloramento próximo à margem esquerda do rio Tacutu, a norte de Bonfim (Figura 35-F). Em ambos os lugares, a imbricação de seixos mostra fluxos de paleocorrentes da direção sul-sudoeste para norte-nordeste

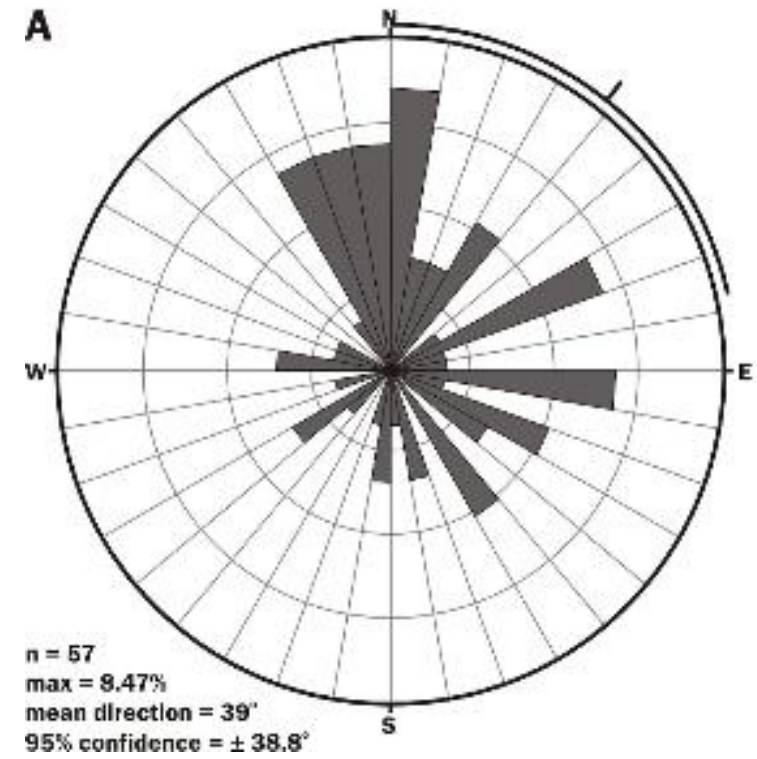

A

$95 \%$ confidence $= \pm 38.8$

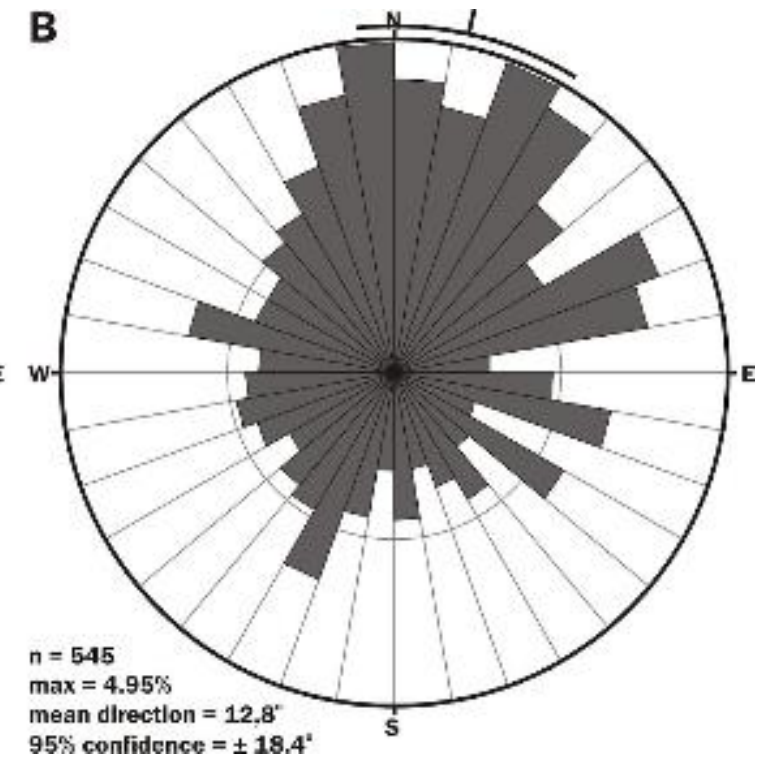

Fonte: Elaborada por André G. Stern. 


\section{DISCUSSÃO E CONCLUSÕES}

A integração de interpretações de imagens de sensoriamento remoto e modelos digitais de terreno com análises de fácies, elementos arquiteturais, paleocorrentes, proveniência e granulometria de dois alvos distintos mas com idades semelhantes em sistemas aluviais da Amazônia brasileira permitiu reconstituir cenários paleogeográficos da evolução do sistema de terraços pleistocênicos da Amazônia Central, da Formação Boa Vista em Roraima e de sucessões correlatas na Guiana Francesa.

\subsection{Terraços pleistocênicos da Amazônia Central}

Datações por diversos autores dos depósitos aluviais da Amazônia Central anteriormente mapeados como Formação Içá têm revelado idade do Pleistoceno tardio para esses depósitos aluviais (deposição anterior a 35 Ma para o estágio III, ver revisão em Pupim et al. [2019]), que de fato apresentam estruturas reliquiares de barras fluviais com pouco retrabalhamento em processos erosivos posteriores (Almeida, 1974; Hayakawa; Rossetti; Valeriano, 2010; Wilkinson et al., 2010; Ruokolainen et al., 2018a, 2018b), compondo um sistema de terraços relacionados a drenagens ativas (Rossetti; Toledo; Góes, 2005; Pupim et al., 2019). Analogamente, idades obtidas para sucessões consideradas equivalentes no estado de Roraima (Formação Boa Vista) também indicam deposição no Pleistoceno tardio, ainda que com sedimentação completamente distinta.

Os resultados obtidos sobre a proveniência das drenagens ativas por análise de minerais pesados na Amazônia Central concordam majoritariamente com dados publicados (Landim et al., 1983; Rossetti; Toledo; Góes, 2005; Horbe et al., 2013), mas merecem algumas considerações a diferença mineralógica entre os afloramentos e os sedimentos do leito dos rios ativos. A baixa ocorrência de inossilicatos e a abundância de opacos nos sedimentos dos terraços pode ser explicada pela ação intempérica destruindo esses minerais mais suscetíveis. A andaluzita revelou-se o principal fator de distinção entre os sistemas de terraços a leste e a oeste de Tefé; contendo teores significativos de andaluzita, aqueles devem estar correlacionados ao rio Madeira, onde esse abunda esse mineral.

Inferências sobre o rumo do paleofluxo por interpretação da orientação de paleoscrolls indicam fluxo para nordeste nos terraços da margem direita do Solimões. Dados medidos em 
estratificações cruzadas em afloramentos têm vetor médio semelhante, embora com maior dispersão em razão da sinuosidade dos sistemas de canais nessa escala. Esses dados de afloramentos corroboram outros, obtidos mais a jusante em trabalhos anteriores (Horbe et al., 2013; Nogueira; Silveira; Guimarães, 2013).

A integração entre paleocorrentes e assembleiass de minerais pesados indica que os terraços da margem direita do Solimões foram construídos em estágios avulsivos dos principais tributários da margem sul (Juruá e Madeira). Inferências nas paleodescargas desses depósitos apontam para fluxos semelhantes e até superiores aos atuais durante a deposição. É importante salientar que, enquanto a bacia do Madeira inclui fontes nos Andes Centrais (rios Madre de Dios, Beni e tributários), o Juruá e o Purus têm sua nascente no alto de Fitzcarrald, onde sedimentos da bacia de antepaís andina foram soerguidos no Plioceno (Espurt et al., 2010) e, assim, têm fontes originalmente andinas, porém recicladas.

A análise de fácies e elementos arquiteturais dos depósitos de terraços pleistocênicos da Amazônia Central revela ambientes análogos aos descritos em depósitos recentes na região por Galeazzi et al. (2018) e Tamura (2019). Dessa forma, os depósitos foram agrupados nas seguintes fácies sedimentares: F1 - areia média maciça, F2 - areia média a fina com cruzadas acanaladas, F3 - areia média a fina com cruzadas tabulares, F4 - areia média a fina com estratificação cruzada tabular de grande porte, F5 - arenitos e pelitos com laminação cruzada, F6 - conglomerado de intraclastos pelíticos e F7 - argila maciça. Foram reconhecidas três associações de fácies, compostas por cinco elementos arquiteturais: associação de fácies de planícies de inundação, composta pelos elementos cunhas de arenitos e pelitos laminados, pelitos tabulares e lentes de conglomerados de intraclastos; associação de fácies de barras fluviais, composta pelo elemento cosets de arenitos com estratificação cruzada; e associação de fácies de topos de barras e canais secundários, composta pelos elementos cosets de arenitos com estratificação cruzada, depósitos de avalanche em laterais de barras e lentes de pelitos.

A organização vertical e lateral dessas associações de fácies está de acordo com o esperado no empilhamento preservado dos ambientes descritos por Galeazzi et al. (2018) e Tamura (2019), com especial interesse na preservação do elemento de avalanche em laterais de barras, diagnóstico de topos de barras e canais secundários, de acordo com Tamura (2019). Nota-se a ausência de depósitos relacionáveis aos talvegues descritos por Galeazzi et al. (2018) e Almeida et al. (2016), provavelmente em decorrência da altura limitada dos afloramentos disponíveis. 
Os estudos em escala regional resultaram no reconhecimento de três estágios principais de desenvolvimento de terraços, com relações de corte indicando eventos de queda do nível de base. A interpretação de morfologias e a reconstituição de direções de fluxo e paleodescargas permitem concluir que:

- o interflúvio Madeira-Purus registra posições antigas do Madeira, quando ele corria para norte;

- o Purus ela afluente do antigo sistema fluvial do Madeira, enquanto construía seu próprio padrão de distribuição;

- o Juruá formou um grande sistema avulsivo que coalesceu lateralmente aos depósitos do Madeira e sofreu alguns episódios de queda no nível de base;

- o Solimões corria por um vale mais amplo que seu vale moderno e, após um estágio inicial de queda no nível da base, estabeleceu um sistema de distribuição com o canal principal, passando da posição mais moderna do sul para a posição norte, possivelmente fluindo para o Rio Negro.

Devido ao reajuste do perfil do rio a montante para o nível do mar, ao aumento da descarga do rio principal ou ao efeito combinado de ambos os processos, eventos de queda no nível de base resultaram em erosão de vales em sedimentos antigos, causando a incisão de tributários e a expansão da Floresta de Terra Firme, a partir de áreas de topografias mais altas, onde a biota já estava isolada em interflúvios separados pelos mesmos rios. Durante e após cada evento de queda no nível de base, o recuo erosivo dos knickpoints dos vales permitiu capturar drenagens maiores em vales de drenagens menores, possibilitando o cruzamento passivo de populações de Terra Firme de uma margem a outra. Um exemplo seria o antigo fluxo do rio Juruá em direção ao vale do Jutaí (Ruokolainen et al., 2018a, 2018b) e sua posterior divergência para a posição moderna devido à captura erosiva durante a queda no nível de base. O caráter local desse processo e as áreas relativamente pequenas de Terra Firme envolvidas podem explicar a incompatibilidade entre idades da separação de pares de espécies por barreiras fluviais.

As principais hipóteses testáveis derivadas desse modelo evolutivo são:

- as populações de táxons de terra firme expandiram-se para a Amazônia Central como, anteriormente, unidades isoladas eram delimitadas por planaltos das 
drenagens principais. Essas expansões se sucederam durante os eventos de queda no nível de base, pela propagação dos efeitos da variação do nível do mar na parte interna do continente ou pelo aumento da descarga de água, cujos registros se encontram em depósitos do final do Pleistoceno. O último desses eventos ocorreu até $45 \mathrm{ka}$;

- os ambientes aquáticos diminuíram gradualmente devido ao avanço das cunhas de sedimentos fluviais andinos;

- florestas alagadas e cerrados abertos ocuparam, nas últimas centenas de milhares de anos, grandes áreas maiores do que hoje, com uma trajetória longa e a gradual migração da terra firme, pelos flancos andinos, e de altos de rochas do embasamento, marcados por eventos de queda no nível de base. Cada um desses eventos implica uma drástica redução da área de floresta inundada, seguida por uma recuperação gradual devido ao alargamento do vale e ao preenchimento por sedimentos de ambientes aquáticos.

\subsection{Formação Boa Vista}

Quanto à Formação Boa Vista, nossos dados revelam um cenário paleogeográfico completamente distinto, ainda que com idades de deposição semelhantes. As lateritas que compõem a Formação Boa Vista inferior (FBVI) resultam do intemperismo in situ de rochas pré-cambrianas e mesozoicas afetadas por condições climáticas úmidas e quentes. Lateritas maciças (Figura 36A) e nodulares/pisolíticas (Figuras 36B e 36C) correspondem a diferentes graus de alteração in situ. Rochas do embasamento pré-cambriano, sedimentos terrígenos da Formação Serra do Tucano e basaltos Apoteri, todos mesozoicos, são as litologias em que se originam as lateritas. Nota-se o retrabalhamento do material laterítico encontrado no topo da FBVI, formando fragmentos de diversos tamanhos, de seixos e matacões. Embora pareça ter havido pouco ou mesmo nenhum transporte desse material, há lugares onde se observou a presença de fragmentos de crosta laterítica maciça próxima ao topo da FBVI (Figura 36D). Alguns pouco fragmentos dessa laterita retrabalhada foram encontrados preenchendo depósitos de canais na base da FBVS (Figura 34A). 
Não foi possível estabelecer idades precisas para as lateritas da FBVI. Sinhá, N. (1968) e Schaefer e Dalrymple (1995) atribuem às lateritas da porção norte do Rupununi e à superfície da plantação associada idade entre o Plioceno e o Pleistoceno. Berrangé (1977) adota o período Eoceno-Oligoceno. Castro, Horbe e Almeida (2016) descrevem dois níveis de crostas lateríticas na cidade de Nova Colina, no sul de Roraima. O nível mais baixo, cerca de $140 \mathrm{~m}$ acima do nível do mar, é composto por laterita ferruginosa vermiforme, a que se atribui a idade no período Plioceno-Pleistoceno. Essa laterita é semelhante às lateritas maciças da FBVI, considerando suas características e seu posicionamento topográfico, portanto, pode-se considerar a idade da FBVI plio-pleistocênica.

\section{Depósitos de canal}

O contato da FBVS com a FBVI é marcado por uma superfície de erosão regional, responsável pelo contato irregular entre as duas unidades. Em alguns lugares, depósitos de canal foram depositados sobre essa superfície de erosão, provavelmente formando uma rede de drenagem semelhante à observada hoje em dia. Os sentidos de paleocorrente são de sul para norte, indicando que essas drenagens eram tributárias do rio Proto-Berbice no momento de sua deposição e que a deposição da FBVS começou antes da captura das drenagens do Alto Branco pelo Rio Branco.

A Figura 39 mostra os locais de medições de paleocorrentes e as bacias de drenagem atuais. Os rios da bacia do Alto Branco (vermelho) mostram mudanças bruscas na direção de seu curso; um exemplo notável é o Tacutu, que inverte seu curso de norte para sul-sudeste. A área entre os rios Tacutu e Rupununi, a norte de Lethem, é um lugar denominado Portal do Rupununi (Souza, L.; Armbruster; Werneke, 2012) e corresponde ao trecho do que seria o canal do rio Proto-Berbice que ligava as bacias do Alto Branco e Essequibo e do Berbice antes da captura de sua drenagem.

As paleocorrentes medidas correspondem provavelmente aos depósitos do que seria referente ao paleo rio Uraricoera, que flui para o norte, e de um paleo rio Tacutu (Figura 37). As últimas medições são particularmente significativas, pois mostram um fluxo nortenordeste no que hoje é o ponto onde o Tacutu muda abruptamente seu curso para sul-sudeste. 
Figura 39 - Modelo digital de terreno, com código de cores para Roraima e áreas adjacentes. Elevações abaixo de $50 \mathrm{~m}$ estão em preto e, acima de $300 \mathrm{~m}$, em branco. Vermelho: bacia do Alto Branco. Azul claro: bacia do Médio/Baixo Rio Branco. Laranja: bacias Essequibo/Berbice/Corentyne.

Azul: outras bacias. Os diagramas de rosa mostram direções de paleocorrentes: (A) paleo rio Uraricoera e (B) paleo rio Tacutu. Os números correspondem a amostras datadas

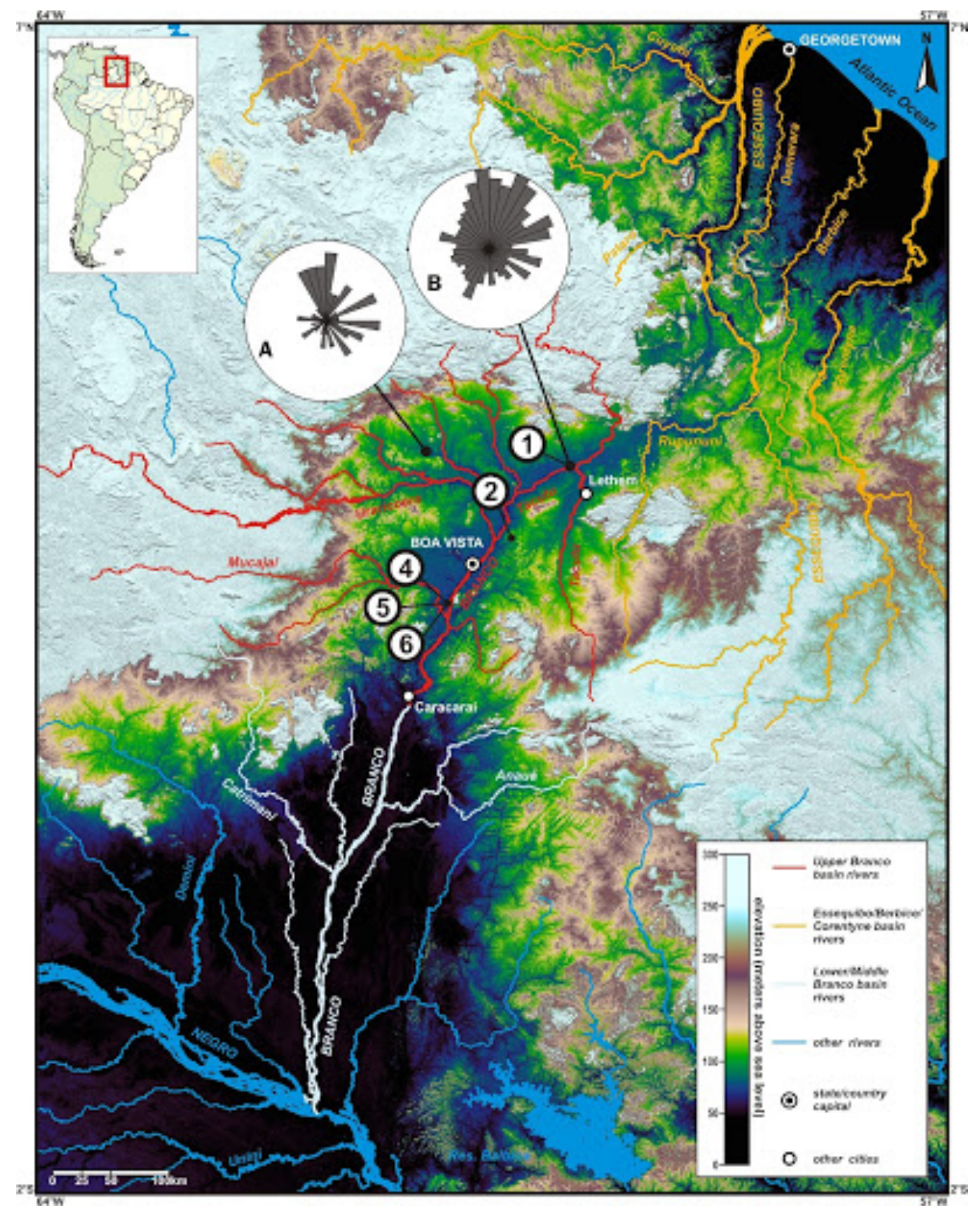

Fonte: Elaborada por Marlei A. C. Chamani.

Depósitos não eólicos são os mais amplamente distribuídos em área e geralmente apresentam distribuição bimodal do tamanho dos grãos, embora haja grande variação nos padrões de curvas granulométricas (Figuras 37 e 38). O tamanho médio dos grãos também mostra uma grande variação, de silte grosso a areia fina. Todas as amostras analisadas são muito mal selecionadas, com forte assimetria, e têm grandes quantidades de matriz granulada (36-50\%). Próximo ao sopé da serra de Pacaraima, as amostras apresentam padrão homogêneo, enquanto as mais distantes mostram padrão variado e nenhuma correlação aparente entre parâmetros granulométricos e as características encontradas na superfície. 
Os sedimentos estudados são imaturos (Folk, 1951), com seleção muito pobre, grande conteúdo de matriz e grãos angulares a subretangulares, indicando pouco transporte de material. Com distribuição bimodal, menor assimetria dos grãos e maior conteúdo matricial, as amostras próximas do sopé da serra de Pacaraima indicam ter sofrido transporte por fluxos de gravidade, num ambiente aluvial tipo leque, embora as morfologias dos leques sejam pouco desenvolvidas ao longo da base da serra de Pacaraima. O material de granulação mais fina que constitui a maior parte dessas amostras provavelmente se originou a partir do profundo intemperismo das rochas pré-cambrianas do Escudo da Guiana (Nahon; Trompette, 1982).

Longe da serra de Pacaraima, as amostras são mais variadas, embora ainda sejam muito mal selecionadas e com alto conteúdo de matriz. Essas características indicam algum grau de retrabalho, provavelmente pela ação de inundações e possível grau de retrabalho eólico, mas ainda com pouco transporte de material e não sendo possível configurá-lo como um ambiente fluvial verdadeiro. Assim, o ambiente deposicional dos sedimentos não eólicos da FBVS é provavelmente semelhante ao proposto por Barbosa e Ramos (1959), com pedimentos extensos lavados por enchentes, transportando sedimentos de terras altas vizinhas, mas com pouco transporte geral. Deve-se notar, no entanto, que Berrangé (1977) descreve a correlação da Formação Savanna do Norte como fluvial, com depósitos bem ordenados e estruturas sedimentares bem desenvolvidas. Assim, é provável que o sistema deposicional tenha evoluído, a nordeste da área estudada (a direção do rio no momento da deposição), para um sistema fluvial maduro.

Depósitos eólicos na FBVS são geralmente associados a características lineares ou parabólicas da superfície, comumente identificadas como dunas eólicas. As amostras desses depósitos mostram uma assinatura característica, com distribuições tendendo ao unimodal, com diâmetro médio maior, menor assimetria e pouca matriz. No entanto, os sedimentos ainda são muito pouco selecionados, e a matriz de grãos finos está sempre presente, com apenas uma das amostras com um conteúdo de matriz suficientemente baixo para se qualificála como submatura (Folk, 1951), sendo as demais imaturas. Essas características indicam retrabalho eólico de outros depósitos de FBVS, com peneiração mais fina de material de granulação. Embora o retrabalho por vento tenha sido suficiente para gerar feições eólicas, os parâmetros granulométricos indicam pouco transporte de material. Assim, embora as características da superfície identificadas por Sinhá, N. (1968) e Latrubesse e Nelson (2001) 
sejam, sem dúvida, de origem eólica, é improvável que a fonte de sedimentos seja externa à bacia, mas que provenha da reformulação de depósitos FBVS. Como indicam as dunas parabólicas próximas a Mucajaí, as direções do vento foram semelhantes às observadas hoje.

\section{Idade da Formação Boa Vista superior e a relação com outras idades na Amazônia}

As idades OSL de cinco amostras da FBVS variam de 37,5 ka, em depósitos não eólicos abaixo das dunas de Mucajaí, a 7,35 ka, em depósitos não eólicos da FBVS próximos a Santa Cecília. Essas idades situam a FBVS no período do Pleistoceno-Holoceno Superior. A idade dos depósitos eólicos no campo das dunas de Mucajaí varia de 21,9 a 20,0 ka. Idades obtidas por Zular et al. (2019) no mesmo campo de dunas estão de acordo com as obtidas aqui, tanto nos depósitos eólicos (23,1 a 17,2 ka) quanto nos subjacentes (51,7 a 27,8 ka). Teeuw e Rhodes (2004) estimaram, para o início da deposição eólica na dunas na República Guiana, uma idade de 15.000 a 17.000 ka.

Essas idades mostram que a principal fase de deposição eólica na FBVS ocorreu durante o último máximo glacial (LGM), quando as condições climáticas na Amazônia eram mais secas do que hoje em dia (Cordeiro et al., 2011; D’Apolito; Absy; Latrubesse, 2013) e as condições climáticas na savana de Rio Branco-Rupununi eram mais áridas, favorecendo a formação de dunas eólicas. Depósitos eólicos de idade semelhante também são encontrados na bacia do Rio Negro (Carneiro Filho et al., 2002) e nos llanos da Colômbia e da Venezuela (Carr et al., 2016). Assim, o LGM foi um período de intensa construção de dunas eólicas no norte da América do Sul. No entanto, embora estudos indiquem que o LGM foi o principal período de deposição eólica, houve outros episódios de atividade antes e depois dele. Carneiro Filho et al. (2002) identificam quatro episódios de atividade eólica entre 32 e 8 ka e associamos a períodos climáticos mais secos. Os mesmos autores concluíram que a estabilização final das dunas ocorreu após $8 \mathrm{ka}$, e Carr et al. (2016) consideraram que o acúmulo de dunas cessou em grande parte após 10 ka. No entanto, Teeuw e Rhodes (2004) e Zular et al. (2019) mostram que a deposição eólica continuou na FBVS até cerca de 1 ka, embora em menor escala. Assim, o principal episódio de atividade eólica na FBVS ocorreu aproximadamente entre 23 e 17 ka, embora depósitos mais jovens também possam haver ocorrido (Gráfico 14). 
Gráfico 14 - Idade da FBV e de outros depósitos sedimentares na Amazônia; quando possível, erros analíticos foram considerados. Azul: depósitos não eólicos de FBV. Vermelho escuro: depósitos eólicos de FBV. Vermelho claro: outros depósitos eólicos no norte da América do Sul. Verde: idade mais antiga dos depósitos aluviais Médio/Baixo Rio Branco. Laranja: terraços fluviais anteriormente considerados como Formação Içá. A barra cinza à direita mostra variações paleoclimáticas na Amazônia

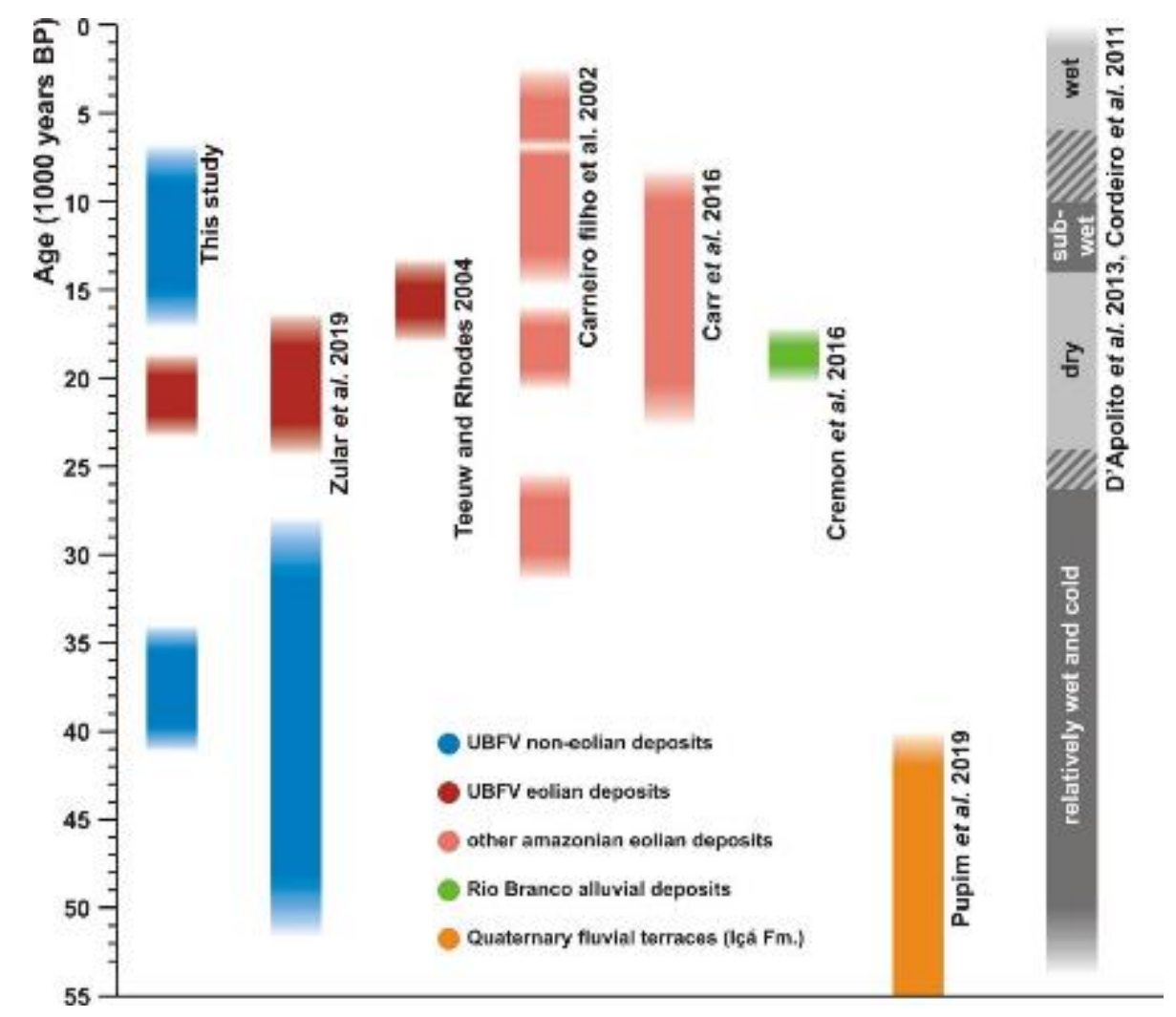

Fonte: Modificado de D’Apolito, Absy e Latrubesse (2013) e de Cordeiro et al. (2011).

Cremon et al. (2016) estabeleceram uma idade de 18,7 ka para os depósitos aluviais mais antigos do Baixo e Médio Rio Branco. Os autores consideram que o atual Rio Branco foi formado pela conexão entre bacias de drenagem menores, e essa é idade mínima da captura do sistema de drenagem do Alto Rio Branco. O sentido norte das paleocorrentes nos depósitos de canal da base da FBVS indicam deposição anterior ao evento de captura e, portanto, são mais antigas. A idade máxima obtida por Zular et al. (2019) para depósitos da FBVS é de 51,7 ka, que é a idade mínima para a superfície de erosão no topo da FBVI e também para o estabelecimento do sistema de drenagem representado pelos depósitos do canal. A deposição de sedimentos eólicos e não eólicos continuou após o evento de captura.

Sedimentos fluviais depositados acima da Formação Solimões numa extensa área das planícies amazônicas foram agrupados sob o nome de Formação Içá; esses depósitos correspondem a uma série de terraços fluviais (Pupim et al., 2019). Os depósitos mapeados 
como Formação Içá ocorrem ao longo do Baixo e Médio Rio Branco até a cidade de Caracaraí e são separados da FBV pelo embasamento cristalino entre Caracaraí e Mucajaí. Isso levanta a questão de uma possível correlação entre as duas unidades. Pupim et al. (2019) obtiveram idades entre 250 e 45 ka para os terraços fluviais antes considerados Formação Içá. As idades mais antigas obtidas para a FBVS neste estudo e por Zular et al. (2019) se sobrepõem às idades mais jovens de Pupim et al. (2019) para esses terraços. Assim, existe pelo menos uma crono-correlação parcial entre essas unidades, embora a maior parte da deposição da FBV tenha ocorrido após a deposição desses terraços. A Figura 13 é uma síntese das relações de idades discutidas acima. 


\section{REFERÊNCIAS}

AITKEN, M. J. An introduction to optical dating: the dating of Quaternary sediments by the use of photon-stimulated luminescence. Geological Magazine, New York/Tokyo: Oxford University Press, v. 136, n. 1, p. 83-108, 1999. doi: https://doi.org/10.1017/S0016756899551777.

ALMEIDA, L. F. G. A drenagem festonada e seu significado foto geológico. In: CONGRESSO BRASILEIRO DE GEOLOGIA, 28., 1974, Porto Alegre. Anais... Porto Alegre, Sociedade Brasileira de Geologia, 1974. v. 7. p. 175-97.

ALMEIDA, R. P.; GALEAZZI, C. P.; FREITAS, B. T.; JANIKIAN, L.; IANNIRUBERTO, M.; MARCONATO, A. Large barchanoid dunes in the Amazon River and the rock record: Implications for interpreting large river systems. Earth and Planetary Science Letters, v. 454, p. 92-102, 2016. doi: https://doi.org/10.1016/j.eps1.2016.08.029.

ALMEIDA, R. P.; FREITAS, B. T.; TURRA, B. B.; FIGUEIREDO, F. T.; MARCONATO, A.; JANIKIAN, L. Reconstructing fluvial bar surfaces from compound cross-strata and the interpretation of bar accretion direction in large river deposits.

Sedimentology, v. 63, n. 3, p. 609-628, 2015. doi: https://doi.org/10.1111/sed.12230.

AMARANTE, O. A. C.; BROWER, M.; ZACK, J.; SÁ, A. L. Atlas do potencial eólico brasileiro. Brasília: Ministério de Minas e Energia, 2001.

ASSINE, M. L. River avulsions on the Taquari megafan, Pantanal wetland, Brazil. Geomorphology, Amsterdam: Elsevier, v. 70, n. 3-4, p. 357-371, 2005. Disponível em: <http://hdl.handle.net/11449/25058>. Acesso em: 6 jun. 2020.

BARBOSA, O.; RAMOS, J. R. A. Território do Rio Branco: aspectos principais da geomorfologia, da geologia e das possibilidades minerais de sua zona setentrional. Rio de Janeiro: SERGRAF-IBGE, 1959.

BERRANGÉ, J. P. The Geology of Southern Guyana, South America: Overseas Geology \& Mineral Resources. London: British Geological Survey, , 1977. ISBN: 0118807714.

BERRANGÉ, J. P.; DEARNLEY, R. The Apoteri volcanic formation tholeitic flows in the North Savannas Graben of Guyana and Brazil. Geologische Rundschau, v. 64, p. 883-899, 1975. Disponível em: $<$ https://link.springer.com/article/10.1007/BF01820702>. Acesso em: 22 jun. 2020.

BOMFIM, L. F. C.; RAMGRAB, G. E.; UCHÔA, I. B.; MEDEIROS, J. B.; VIEGAS FILHO, J. R.; MANDETTA, P.; KUYUMJIAM, R. M.; PINHEIRO, R. S. 1974. Projeto Roraima: relatório final. Manaus: CPRM, 1974.

BOUBLI, J. P.; RIBAS, C.; LYNCH ALFARO, J. W.; ALFARO, M. E.; da SILVA, M. N. F.; PINHO, G. M.; FARIAS, I. P. Spatial and temporal patterns of diversification on the Amazon: a test of the riverine hypothesis for all diurnal primates of Rio Negro and Rio Branco in Brazil. Molecular Phylogenetics and Evolution, v. 82-B, p. 400-41, 2014. doi: http://dx.doi.org/10.1016/j.ympev.2014.09.005. 
BRAUN, O. P. G.; RAMGRAB, G. E. Geologia do território de Roraima. In: CONGRESSO BRASILEIRO DE GEOLOGIA, 26., 1972, Belém. Anais... Belém: Sociedade Brasileira de Geologia, 1972. p. 68-70.

CAMPBELL JR., K. E. Late Miocene onset of the Amazon River and the Amazon deep-sea fan: Evidence from the Foz do Amazonas Basin: Comment. Geology, v. 38, n. 7, p. e212, 2010. doi: https://doi.org/10.1130/G30633C.1.

CAMPBELL JR., K. E.; FRAILEY, C. D.; ROMERO-PITTMAN, L. The Pan-Amazonian Ucayali Peneplain, late Neogene sedimentation in Amazonia, and the birth of the modern Amazon River system. Palaeogeography, Palaeoclimatology,

Palaeoecology, v. 239, n. 1-2, p. 166-219, 2006. doi:

https://doi.org/10.1016/j.palaeo.2006.01.020.

CAMPBELL JR., K. E.; HEIZLER, M.; FRAILEY, C. D.; ROMERO-PITTMAN, L.; PROTHERO, D. R. Upper Cenozoic chronostratigraphy of the southwestern Amazon Basin. Geology, v. 29, n. 7, p. 595-598, 2001. doi: https://doi.org/10.1130/00917613(2001)029<0595:UCCOTS >2.0.CO;2.

CAPUTO, M. V. Stratigraphy, Tectonics, Paloeclimatology and Paleogeogrphy of Northern Basin of Brazil. Tese (Doutorado) - University of Califórnia, Santa Barbara, 1984.

CAPUTO, M. V.; SOARES, E. A. A. Eustatic and tectonic change effects in the reversion of the transcontinental Amazon River drainage system. Brazilian Journal of Geology, v. 46, n. 2, p. 301-328, 2006. doi: https://doi.org/10.1590/2317-4889201620160066.

CAPUTO, M. V.; RODRIGUES, R.; VASCONCELOS, D. N. Nomenclatura Estratigráfica da Bacia do Amazonas: história e atualização. In: CONGRESSO BRASILEIRO DE GEOLOGIA, 26., 1972, Belém. Anais... Belém: Sociedade Brasileira de Geologia, 1972. p. 35-46.

CARNEIRO FILHO, A.; SCHWARTZ; D., TATUMI; S. H.; ROSIQUE, T. Amazonian paleodunes provide evidence for drier climate phases during the Late PleistoceneHolocene. Quaternary Research, v. 58, n. 2, p. 205-209, 2002. doi: https://doi.org/10.1006/qres.2002.2345.

CARNEIRO, R. G.; ANDRADE, F. G.; SILVA, G. O. P. 1968. Reconhecimento geológico no Território Federal de Roraima: Gráben do Tacutu. Relatório Siex. Belém: Petrobras/Renor, 1968. p. 130-3578.

CARR, A. S.; ARMITAGE, S. J.; BERRÍO, J.-C.; BILBAO, B. A.; BOOM, A. An optical luminescence chronology for late Pleistocene aeolian activity in the Colombian and Venezuelan Llanos. Quaternary Research, v. 85, n. 2, p. 299-312, 2016. doi: https://doi.org/10.1016/j.yqres.2015.12.009.

CASTRO, R. T.; HORBE, A. M. C.; ALMEIDA, C. M. A crosta laterítica ferro-titanífera da Vila Nova Colina e a lateritização no sul de Roraima. Acta Amazonica, v. 46, n. 1, p.: 47-60, 2016. doi: https://doi.org/10.1590/1809-4392201500993. 
CHENG, H.; SINHA, A.; CRUZ, F. W.; WANG, X.; EDWARDS, R. L.; D’HORTA, F. M.; RIBAS, C. C.; VUILLE, M.; STOTT, L.; AULAR, A. S. Climate change patterns in Amazonia and biodiversity. Nature Communications, n. 4, p. 1-6, 2013. doi: https://doi.org/10.1038/ncomms2415.

CORDANI, U. G.; TEIXEIRA, W.; D'AGRELLA-FILHO, M. S.; TRINDADE, R. I. The position of the Amazonian Craton in supercontinents. Gondwana Research, v. 15, n. 3-4, p. 396-407, 2009. doi: https://doi.org/10.1016/j.gr.2008.12.005.

CORDANI, U. G.; BRITO NEVES, B. B.; FUCK, R. A.; PORTO, R.; THOMAZ FILHO, A.; CUNHA, F. M. B. Estudo preliminar de integração do Pré-Cambriano com os eventos tectônicos das bacias sedimentares brasileiras. Ciência - Técnica - Petróleo, Rio de Janeiro: Petrobras/Cempes/Sintep, n. 14, p. 1-70, 1984. Disponível em: $<$ https://repositorio.usp.br/item/001464085>. Acesso em: 6 jun. 2020.

CORDEIRO, R. C.; TURCQ, B.; SIFEDDINE, A.; LACERDA, L. D.; SILVA FILHO, E. V.; GUEIROS, B.; POTTY, Y. P.; SANTELLI, R. E.; PÁDUA, E. O.; PATCHINELAM, S. R. Biogeochemical indicators of environmental changes from $50 \mathrm{ka}$ to $10 \mathrm{ka}$ in a humid region of the Brazilian Amazon. Palaeogeography, Palaeoclimatology, Palaeoecology, v. 299, n. 3-4, p. 426-436, 2011. doi: https://doi.org/10.1016/j.palaeo.2010.11.021.

CPRM. Companhia de Pesquisa de Recursos Minerais. Serviço Geológico do Brasil. Geologia e Recursos Minerais do Estado do Amazonas. Org. Nelson Joaquim Reis et al. Manaus: CPRM, 2006.

CPRM. Companhia de Pesquisa de Recursos Minerais. Serviço Geológico do Brasil. Carta Geológica do Brasil ao Milionésimo. 2004. SIG Brasil. 1 CD-ROM.

CPRM. Companhia de Pesquisa de Recursos Minerais. Serviço Geológico do Brasil. Projeto Roraima Central: Folhas NA.20-X-B; NA.20-X-D inteiras e parte das folhas NA.20X-A; NA.20-X-C; NA.21-V-A; NA.21-V-C. Escala 1:500.000. PDF. 1999.

Disponível em:

$<$ http://www.cprm.gov.br/arquivos/pdf/roraima/roraima_creditos.pdf $>$. Acesso em: 12 jun. 2020.

CPRM. Companhia de Pesquisa de Recursos Minerais. Serviço Geológico do Brasil.

Programa Levantamentos Geológicos Básicos do Brasil: Folhas NA.20-X; NA.21V. Roraima Central. Escala 1:500.000. Brasília: CPRM, 1998.

CPRM-PLGB. Companhia de Pesquisa de Recursos Minerais. Serviço Geológico do Brasil. Programa Levantamentos Geológicos Básicos do Brasil: Folhas NA.20-X-B e NA.20-X-D (inteiras), NA.20-X-A, NA.20-X-C, NA.21-V-A e NA.21-V-C (parciais). Estado do Amazonas. Escala 1:500.000. Brasília: CPRM, 1999. 1 CD-ROM.

CRACRAFT, J. Historical Biogeography and Patterns of Differentiation within the South American Avifauna: Areas of Endemism. Ornithological Monographs, California: University Press/American Ornithologists' Union, v. 36, p. 49-84, 1985. doi: https://doi.org/10.1017/S0016756899551777. 
CREMON, E. H.; ROSSETTI, D. F.; SAWAKUCHI, A. O.; COHEN, M. C. L. The role of tectonics and climate in the Late Quaternary evolution of a northern Amazonian River. Geomorphology, Amsterdam: Elsevier, v. 271, p. 22-39. 2016. doi: https://doi.org/10.1016/j.geomorph.2016.07.030.

D’APOLITO, C.; ABSY, M. L.; LATRUBESSE, E. M. The Hill of Six Lakes revisited new data and re-evaluation of a key Pleistocene Amazon site. Quaternary Science Reviews, v. 76, p. 140-155, 2013. doi: https://doi.org/10.1016/j.quascirev.2013.07.013.

DOBSON, D. M.; DICKENS, G. R.; REA, D. K. Terrigenous sediment on Ceara Rise: a Cenozoic record of South American orogeny and erosion. Palaeogeography, Palaeoclimatology, Palaeoecology, v. 165, n. 3-4, p. 215-229, 2001. doi: https://doi.org/10.1016/S0031-0182(00)00161-9.

DOBSON, D. M.; DICKENS, G. R.; REA, D. K. Terrigenous sedimentation at Ceara Rise. In: SHACKLETON, N. J.; CURRY, W. B.; RICHTER, C.; BRALOWER, T. J. (Ed.). Proceedings of the Ocean Drilling Program: scientific results. Texas: College Station, 1997. v. 154. p. 465-473. Disponível em: $<$ http://wwwodp.tamu.edu/publications/154_SR/ABSTRACT/23.HTM>. Acesso em: 12 jun. 2020.

DOTT, R. H. Wacke, graywacke and matrix: what approach to immature sandstone classification? Journal of Sedimentary Research, v. 34, n. 3, p. 625-632. 1964. doi: https://doi.org/10.1306/74D71109-2B21-11D7-8648000102C1865D.

DURY, G. H. Discharge prediction, present and former, from channel dimensions. Journal of Hydrology, v. 30, n. 3, p. 219-245, 1976. doi: https://doi.org/10.1016/00221694(76)90102-5.

EIRAS, J. F. Cenário geológico das bacias sedimentares do Brasil. In: Prospecção e Desenvolvimento de Campos de Petróleo e Gás (Schlumberger): Projeto Multimin Tecnologia. Parte II - Tectônica, Sedimentação e Sistemas Petrolíferos da Bacia Solimões, Estado do Amazonas. 2005. Disponível em: $<$ http:// acd.ufrj.br/multimin/mmp/textos/index.htm>. Acesso em: 12 jun. 2020.

EIRAS, J. F.; BECKER, C. R.; SOUZA, E. M.; GONZAGA, F. G.; SILVA, J. G. F.; DANIEL, L. M. F.; MATSUDA, N. S.; FEIJÓ, F. J. Bacia do Solimões. Boletim de Geociências da Petrobrás, v. 8, n. 1, p. 17-45, 1994.

EIRAS, J. F.; KINOSHITA, E. M. Geologia e perspectivas petrolíferas da Bacia do Tacutu. In: RAJA GABAGLIA, G. P.; MILANI, E. J. (Ed.). Origem e evolução das bacias sedimentares. Rio de Janeiro: Petrobras, 1990. p. 197-220.

EIRAS, J. F.; KINOSHITA, E. M. Evidências de movimentos transcorrentes na Bacia do Tacutu. In: SEMINÁRIO SOBRE RIFTES INTRACONTINENTAIS, 1., Rio de Janeiro. Anais... Rio de Janeiro: Petrobras/Deplex, 1987. p. 193-208. 
ESPURT, N.; BABY, P.; BRUSSET, S.; RODDAZ, M; HERMOZA, W.; BARBARAND, J. The Nazca Ridge and Uplift of the Fitzcarrald Arch: Implications for Regional Geology in Northern South America. In: HOORN, C.; WESSELINGH, F. P. (Ed.). Amazonia, landscape and species evolution: a look into the past. Chichester, UK: Wiley-Blackwell, 2010. v. 6. p. 89-102. ISBN 978-1-4051-8113-6. doi: https://doi.org/10.1002/9781444306408.ch6.

FERREIRA-FERREIRA, J.; SILVA, T. S. F.; STREHER, A. S.; AFFONSO, A. G.; ALEMIDA FURTADO, L. F.; FORSBERG, B. R.; VALSECCHI, J.; QUEIROZ, H. L.; MORAES NOVO, E. M. L. M. Combining ALOS/PALSAR derived vegetation structure and inundation patterns to characterize major vegetation types in the Mamiraua Sustainable Development Reserve, Central Amazon floodplain, Brazil. Wetlands Ecology and Management, v. 23, n. 1, p. 41-59, 2015. doi: https://doi.org/10.1007/s11273-014-9359-1.

FIGUEIREDO, J.; HOORN, C.; VEN, P.; SOARES, E. Late Miocene onset of the Amazon River and the Amazon deep-sea fan: evidence from the Foz do Amazonas Basin: Reply. Geology, v. 38, n. 7, p. e213, 2010. doi: https://doi.org/10.1130/G31057Y.1.

FIGUEIREDO, J.; HOORN, C.; VEN, P.; SOARES, E. Late Miocene onset of the Amazon River e the Amazon deep-sea fan: Evidence from the Foz do Amazonas Basin. Geology, v. 37, n. 7, p. 619-622, 2009. doi: https://doi.org/10.1130/G25567A.1.

FILIZOLA, N.; GUYOT, J. L; Fluxo de sedimentos em suspensão nos rios da Amazônia. Revista Brasileira de Geociências, v. 41, n. 4, p. 566-576, 2011. Disponível em: $<$ http://www.ppegeo.igc.usp.br/index.php/rbg/article/view/7853>. Acesso em: 6 jun. 2020 .

FOLK, R. L. Stages of textural maturity. Journal of Sedimentary Research, v. 21, n. 3, p. 127-130, 1951. doi: https://doi.org/10.2110/jsr.21.127.

FOLK, R. L.; WARD, W. C. Brazos River bar [Texas]: a study in the significance of grain size parameters. Journal of Sedimentary Research, v. 27, n. 1, p. 3-26, 1957. doi: https://doi.org/10.1306/74D70646-2B21-11D7-8648000102C1865D.

GALBRAITH, R. F.; ROBERTS, R. G.; LASLETT, G. M.; YOSHIDA, H.; OLLEY, J. M. Optical dating of single and multiple grains of quartz from Jinmium rock shelter, northern Australia, part 1: experimental design and statistical models. Archaeometry, v. 41, n. 2, p. 339-364. 1999. doi: https://doi.org/10.1111/j.1475-4754.1999.tb00987.x.

GALEAZZI, C. P.; ALMEIDA, R. P.; MAZOCA, C. E. M.; BEST, J. L.; FREITAS, B. T.; IANNIRUBERTO, M.; CISNERO, J.; TAMURA, L. N. The significance of superimposed dunes in the Amazon River: Implications for how large rivers are identified in the rock record. Sedimentology, v. 65 , n. 7, p. 1-16, 2018. doi: https://doi.org/10.1111/sed.12471.

GALVÃO, P. H. F.; DEMÉTRIO, J. G. A.; SOUZA, E. L.; PINHEIRO, C. S. S.; BAESSA, M. P. M. Hidrogeologia e geometria dos aquíferos das formações cretáceas Içá e Solimões, Bacia Paleozoica do Solimões, na região de Urucu, Amazonas. Revista Brasileira de Geociências, v. 42, n. 1, p. 141-152, 2012. doi: http://dx.doi.org/10.5327/Z0375-75362012000500012 
GARZÓN-ORDUÑA, I. J.; BENETTI-LONGHINI, J. E.; BROWER, A. V. Z|. Timing the diversification of the Amazonian biota: butterfly divergences are consistent with Pleistocene refugia. Journal of Biogeography, v. 41, n. 9, p. 1631-1638, 2014.

GONÇALVES JÚNIOR, E. S.; AMARAL SOARES, E. A.; TATUMI, S. H.; YEE, M.; RAMIREZ MITTANI, J. C. Pleistocene-Holocene sedimentation of SolimõesAmazon fluvial system between the tributaries Negro and Madeira, Central Amazon. Brazilian Journal Geology, v. 46, n. 2, p. 167-180, 2016. doi: https://doi.org/10.1590/2317-4889201620160009.

GOVIN, A.; CHIESSI, C. M.; ZABEL, M. ; SAWAKUCHI, A. O.; HESLOP, D.; HÖRNER, T.; ZHANG, Y.; MULITZA, S. Terrigenous input off northern South America driven by changes in Amazonian climate and the North Brazil Current retroflection during the last 250 ka. Climate of the Past, v. 10, n. 2, p. 843-862, 2014. doi: https://doi.org/10.5194/cp-10-843-2014.

GROHMANN, C. H.; CAMPANHA, G. A .C.; SOARES JUNIOR, A. V. OpenStereo: um programa livre e multiplataforma para análise de dados estruturais. In: XIII SIMPÓSIO NACIONAL DE ESTUDOS TECTÔNICOS, 13., 15-19 maio 2011, Campinas. Anais... Campinas: Sociedade Brasileira de Geologia, 2011. p. 26-28. Disponível em: $<$ http://igc.usp.br/openstereo/wpcontent/uploads/sites/18/2018/11/Grohmann_etal_2011_13SNET_openstereo.pdf $>$. Acesso em: 6 jun. 2020.

GUERRA, A. T. Expedição geomorfológica no território de Rio Branco. Revista Brasileira de Geografia, Rio de Janeiro: Conselho Nacional de Geografia, n. 10, série A, 1957.

GUPTA, A. (Ed.). Large rivers: geomorphology and management. Leeds, UK: School of Geography/Singapore: National University of Singapore, 2007[1985]. Disponível em: $<$ https://sudartomas.files.wordpress.com/2012/11/largeriversgeomorphologyandmanagement.pdf $>$. Acesso em: 12 jun. 2020.

GUYOT, J. L.; JOUANNEAU, J. M.; SOARES, L.; BOAVENTURA, G. R.; MAILLET, N.; LAGANE, C. Clay mineral composition of river sediments in the Amazon Basin. Catena, v. 71, n. 2, p. 340-356, 2007. doi: https://doi.org/10.1016/j.catena.2007.02.002.

HARTLEY, A. J.; WEISSMANN, G. S.; NICHOLS, G. J.; WARWICK, G. L. Large distributive fluvial systems: characteristics, distribution, and controls on development. Journal of Sedimentary Research, v. 80, n. 2, p. 167-183. 2010. doi: https://doi.org/10.2110/jsr.2010.016.

HAYAKAWA, E. H.; ROSSETTI, D. F.; VALERIANO, M. M. Applying DEM-SRTM for reconstructing a late Quaternary paleodrainage in Amazonia. Earth and Planetary Science Letters, v. 297, n. 1-2, p. 262-270, 2010. doi: https://doi.org/10.1016/j.eps1.2010.06.028.

HOGARTH, D. G.; OLIVEIRA, R.; RICE, A. H. The Rio Branco, Uraricuera, and Parima: Discussion. The Geographical Journal, v. 71, n. 4, p. 345-356, 1928. doi: https://doi.org/10.2307/1782412. 
HOORN, C. An environmental reconstruction of the palaeo-Amazon River system (MiddleLate Miocene, NW Amazonia). Palaeogeography, Palaeoclimatology, Palaeoecology, v. 112, n. 3-4, p. 187-238, 1994. doi: https://doi.org/10.1016/00310182(94)90074-4.

HOORN, C.; BOGOTÁ, G. R.; ROMERO-BAEZ, M.; LAMMERTSM, E. I.; FLANTUA, S. G. A.; DANTAS, E. L.; DINO, R.; CARMO, D. A.; CHEMALE JUNIOR, F. The Amazon at sea: onset and stages of the Amazon River from a marine record in the Foz do Amazonas Basin (Brazilian Equatorial Margin), with special reference to vegetation turnover in the Plio-Pleistocene. Global and Planetary Change, v. 153, p. 51-65, 2017. doi: https://doi.org/10.1016/j.gloplacha.2017.02.005.

HOORN, C.; WESSELINGH, F. P.; STEEGE, H.; BERMUDEZ, M. A.; MORA, A.; SEVINK, J.; SANMARTÍN, I.; SANCHEZ-MESEGUER, A.; ANDERSON, C. L.; FIGUEIREDO, J. P.; JARAMILLO, C.; RIFF, D.; NEGRI, F. R.; HOOGHIEMSTRA, H.; LUNDBERG, J.; STADLER, T.; SÄRKINEN, T.; ANTONELLI, A. Amazonia through Time: Andean Uplift, Climate Change, Landscape Evolution, and Biodiversity. Science, v. 330, n. 6006, p. 927-931, 2010. doi: https://doi.org/10.1126/science.1194585.

HORBE, A. M. C.; TRINDADE, I. R.; DANTAS, E. L.; SANTOS, R. V.; RODDAZ, M. Provenance of quaternary and modern alluvial deposits of Amazonian floodplain (Brazil) inferred from major and trace elements na $\mathrm{Pb}-\mathrm{Nd}-\mathrm{Sr}$ isotopes.

Paleogeography, Palaeoclimatology, Palaeoecology, v. 411, p. 144-154, 2014. doi: https://doi.org/10.1016/j.palaeo.2014.06.019.

HORBE, A. M. C.; MOTTA, M. B.; ALMEIDA, C. M.; DANTAS, E. L.; VIEIRA, L. C. Provenance of Pliocene and recent sedimentary deposits in western Amazônia, Brazil: consequences for the paleodrainage of the Solimões-Amazonas River. Sedimentary Geology, v. 296, p. 9-20, 2013. doi: https://doi.org/10.1016/j.sedgeo.2013.07.007.

HOVIUS, N., 1998. Controls of sediments supply by large rivers. In: SHANLEY, K. W.; McCABE, P. J. (Ed.). Relative role of eustasy climate and tectonism in continental rocks. [S.1]: Society for Sedimentary Petrology, 1998. p. 3-16. Special Publication.

IRION, G.; KALLIOLA, R. Long-term landscape development processes in Amazonia. In: HOORN, C.; WESSELINGH, F. P. (Ed.). Amazônia, landscape and species evolution: a look into the Past. Chichester, UK: Wiley-Blackwell, 2010. c. 11. p. 185197. ISBN 978-1-4051-8113-6.

IRION, G.; MÜLLER, J.; MORAIS, J. O.; KEIM, G.; MELLO, J. M.; JUNK, W. J. The impact of Quaternary sea level changes on the evolution of the Amazonian lowland. Hydrological Processes, v. 23, n. 22, p. 3168-3172, 2009. doi: https://doi.org/10.1002/hyp.7386.

JARAMILLO, C.; ROMERO, I.; D’APOLITO, C.; BAYONA, G.; DUARTE, E.; LOUWYE, S.; ESCOBAR, J.; LUQUE, J.; CARRILLO-BRICEÑO, J. D.; ZAPATA, V.; MORA, A.; SCHOUTEN, S.; ZAVADA, M.; HARRINGTON, G.; ORTIZ, J.; WESSELINGH, F. P. Miocene flooding events of western Amazonia. Science Advances, v. 3, n. 5, p. 1-11, 2017. doi: https://doi.org/10.1126/sciadv.1601693. 
KING, L. C. A geomorfologia do Brasil oriental. Revista Brasileira de Geografia, v. 18, n. 2, p. 147-265, 1956. Disponível em:

$<$ https://biblioteca.ibge.gov.br/visualizacao/periodicos/115/rbg_1956_v18_n2.pdf $>$. Acesso em: 12 jun. 2020.

KING, T. A.; ELLIS, W. G.; MURRAY, D. W.; SHACKLETON, N. J.; HARRIS, S. E. Miocene evolution of carbonate sedimentation at the Ceara Rise: a multivariate data/proxy approach. In: SHACKLETON, N. J.; CURRY, W. B.; RICHTER, C.; BRALOWER, T. J. (Ed.). Proceedings of the Ocean Drilling Program: scientific results. Texas: College Station, 1997. v. 154. p. 349-365. Disponível em: $<$ https://pdfs.semanticscholar.org/b108/83fe94a4ef561 eaa43667ad992db79dec35e.pdf ?_ga $=2.25748859 .730481957 .1591834621-1811830792.1591834621>$. Acesso em: 12 jun. 2020.

LANDIM, P. M. B.; BÓSIO, N. J.; WU, F. T.; CASTRO, P. R. M. Minerais pesados provenientes do leito do rio Amazonas. Acta Amazônica, v. 13, n. 1, p. 51-72, 1983. doi: https://doi.org/10.1590/1809-43921983131051.

LATRUBESSE, E. M.; WILKINSON, M. J.; ABAD, J. D. Large rivers and megafans. Sedimentary Geology. v. 301, p. 91-92, 2014. Preface. doi: https://doi.org/10.1016/j.sedgeo.2014.01.004.

LATRUBESSE, E. M.; COZZUOL, M.; SILVA CAMINHA, S. A. F.; RIGSBY, C. A.; ABSY, M. L.; JARAMILLO, C. The Late Miocene paleogeography of the Amazon Basin and the evolution of the Amazon River system. Earth-Science Reviews, v. 99, n. 3-4, p. 99-124, 2010. doi: https://doi.org/10.1016/j.earscirev.2010.02.005.

LATRUBESSE, E. M.; FRANZINELLI, E. The Holocene alluvial plain of the middle Amazon River, Brazil. Geomorphology, v. 44, n. 3-4, p. 241-257, 2002. doi: https://doi.org/10.1016/S0169-555X(01)00177-5.

LATRUBESSE, E. M.; NELSON, B. W. Evidence for late Quaternary eolian activity in the Roraima-Guyana region. Catena, v. 43, n. 1, p. 63-80, 2001. doi: https://doi.org/10.1016/S0341-8162(00)00114-4.

LATRUBESSE, E. M.; RANCY, A.; RAMONELL, C.; SOUZA FILHO, J. P. A Formação Solimões: uma formação do Mio-Plioceno da Amazônia sul ocidental. In: SIMPÓSIO DE GEOLOGIA DA AMAZÔNIA, 4., 1994, Belém. Boletim de Resumos Expandidos. Belém: SBG-Núcleo Norte, 1994. p. 204-205.

LEWIS, D. G.; McCONCHIE, D. 1994. Analytical Sedimentology. New York, London, Chapman and Hall, p. 197.

LOCZY, L. Contribuição a paleogeografia e história do desenvolvimento geológico da Bacia do Amazonas. Boletim Divisão Geológica e Mineralógica, Rio de Janeiro, v. 223, p. $1-96,1996$.

MAIA, R. G. N.; GODOY, H. K.; YAMAGUTI, H. S.; MOURA, P. A.; COSTA, F. S .F.; HOLANDA, M. A.; COSTA, J. A. Projeto Carvão no Alto Solimões: relatório final. Brasília, DF: DNPM-CPRM, 1977. Disponível em: $<$ http://rigeo.cprm.gov.br/jspui/bitstream/doc/9392/8/rel_carvao_alto_solimoes_finalv 8.pdf $>$. Acesso em: 6 jun. 2020. 
MANGE, M. A.; MAURER, H. F. W. Heavy minerals in colors. London: Chapman \& Hall, 1992.

MAPES, R. W. Past and present provenance of the Amazon River. Dissertation (Doctor of Philosophy) - College of Arts and Sciences, University of North Carolina, Chapel Hill, 2009. doi: https://doi.org/10.17615/s09s-f385.

McCONNELL, R. B. Notes and Discussions, Fundamental Fault Zones in the Guiana and West African Shields in relation to presumed axes of Atlantic spreading. Geological Society of America Bulletin, v. 80, n. 9, p. 1775-1782, 1969. doi: https://doi.org/10.1130/0016-7606(1969)80[1775:NADFFZ]2.0.CO;2.

McCONNELL, R. B. 1968. Planation surfaces in Guyana. The Geographical Journal, v. 134, n. 4, p. 506-520, 1968. doi: https://doi.org/10.2307/1796379.

MEADE, R. H. Transcontinental moving and storage: the Orinoco and Amazon rivers transfer the Andes to the Atlantic. In: GUPTA, A. (Ed.). Large rivers: geomorphology and management. Leeds, UK: School of Geography/Singapore: National University of Singapore, 2007[1985]. c. 4. p. 45-63. Disponível em: $<$ https://sudartomas.files.wordpress.com/2012/11/largeriversgeomorphologyandmanagement.pdf $>$. Acesso em: 12 jun. 2020.

MEADE, R. H. Suspended sediments of the modern amazon and Orinoco Rivers. Quaternary International, v. 21, p. 29-39, 1994. doi: https://doi.org/10.1016/10406182(94)90019-1.

MELO, A. F. F.; VILLAS BOAS, P. F. Caracterização e distribuição da Formação Içá na porção noroeste do estado do Amazonas. In: SIMPÓSIO DE GEOLOGIA DA AMAZÔNIA, 4., 1994, Belém. Boletim de Resumos Expandidos. Belém: SGBNúcleo Norte, 1994. p. 210-211.

MENESES, M. E. N. S.; COSTA, M. L.; COSTA, J. A. V. Os lagos do lavrado de Boa VistaRoraima: fisiografia, físico-química das águas, mineralogia e química dos sedimentos. Revista Brasileira de Geociências, v. 37, n. 3, p. 478-489, 2007. Disponível em: $<$ http://www.ppegeo.igc.usp.br/index.php/rbg/article/view/9258>. Acesso em: 12 jun. 2020 .

MIALL, A. D. How do we identify big rivers? And how big is big? Sedimentary Geology, v. 186, n. 1-2, p. 39-50, 2006. doi: https://doi.org/10.1016/j.sedgeo.2005.10.001.

MIALL, A. D. Principles of Sedimentary Basin Analysis. 3rd ed. New York: SpringerVerlag, 2000.

MIALL, A. D. The Geology of Fluvial Deposits: Sedimentary Facies, Basin Analysis and Petroleum Geology. Berlin: Springer, 1996.

MIALL, A. D. Architectural-Element Analysis: a New Method of Facies Analysis Applied to Fluvial Deposits. Earth-Science Reviews, v. 22 n. 4, p. 261-308, 1985. doi: https://doi.org/10.1016/0012-8252(85)90001-7. 
MIALL, A. D.; JONES, B. G. Fluvial Architecture of the Hawkesbury Sandstone (Triassic), near Sydney, Australia. Journal of Sedimentary Research, v. 73, n. 4, p. 531-545, 2003. doi: https://doi.org/10.1306/111502730531.

MILANI, E. J.; THOMAZ FILHO, A. 2000. Sedimentary Basins of South America. In: CORDANI, U. G.; MILANI, E. J.; THOMAZ FILHO, A.; CAMPOS, D. A. (Ed.). Tectonic evolution of South America, Rio de Janeiro: 31 st International Geological Congress, 2000. Special Edition. p. 389-449.

MORTON, A. C.; HALLSWORTH, C. R. Processes Controlling the Composition of Detrital Heavy Mineral Assemblages in Sandstones. Sedimentary Geology, v. 124, n. 1-4, p. 3-29, 1999. doi: http://dx.doi.org/10.1016/S0037-0738(98)00118-3.

MOTTA, M. B. Proveniência da Formação Içá e de sedimentos do rio Solimões, entre os municípios de Tefé e Manacapuru - Amazonas. Dissertação (Mestrado em Geologia) - Instituto de Ciências Exatas, Universidade Federal do Amazonas, Manaus, 2008. Disponível em: $<$ http://rigeo.cprm.gov.br/jspui/bitstream/doc/400/1/ diss_marcelo_motta.pdf $>$. Acesso em: 12 jun. 2020.

MURRAY, A. S.; WINTLE, A. G. The single aliquot regenerative dose protocol: potential for improvements in reliability. Radiation Measurements, v. 37, n. 4-5, p. 377-381, 2003.

MURRAY, A. S.; WINTLE, A. G. Luminescence dating of quartz using an improved singlealiquot regenerative-dose protocol. Radiation Measurements, v. 32, n. 1, p. 57-73, 2000. doi: https://doi.org/10.1016/S1350-4487(99)00253-X.

NAHON, D.; TROMPETTE, R. Origin of siltstones: glacial grinding versus weathering. Sedimentology, v. 29, n. 1, p. 25-35, 1982. doi: 10.1111/j.1365-3091.1982.tb01706.x.

NAKA, L. N.; BECHTOLDT, C. L.; HENRIQUES, L. M. P.; BRUMFIELD, R. T. 2012. The Role of Physical Barriers in the Location of Avian Suture Zones in the Guiana Shield, Northern Amazonia. The American Naturalist, v. 179, n. 4 . p. E115-E132, 2012. Disponível em: $<$ http://www.jstor.org/stable/10.1086/664627>. Acesso em: 12 jun. 2020.

NASCIMENTO JR., D. R.; SAWAKUCHI, A. O.; GUEDES, C. C. F.; GIANNINI, P. C. F.; GROHMANN, C. H.; FERREIRA, M. P. Provenance of sands from the confluence of the Amazon and Madeira rivers based on detrital heavy minerals and luminescence of quartz and feldspar. Sedimentary Geology, v. 316, p. 1-12, 2015. Elsevier. doi: http://dx.doi.org/10.1016/j.sedgeo.2014.11.002.

NICHOLS, G. J. Sedimentology and stratigraphy. 2nd ed. London: Wiley-Blackwell, 2009. ISBN 978-1-4051-3592-4. Disponível em: $<$ https://raregeologybooks.files.wordpress.com/2014/09/sedimentology-andstratigraphy-by-gary-nichols.pdf $>$. Acesso em: 6 jun. 2020.

NIE, J.; RUETENIK, G.; GALLAGHER, K.; HOKE, G. D.; GARZIONE, CM. N.; WANG, W.; STOCKLI, D. F.; HU, X.; ZHAO, W.; WANG, Y.; STEVENS, T.; DANISIK, M.; LIU, S. Rapid incision of the Mekong River in the middle Miocene linked to monsoonal precipitation. Nature Geoscience, v. 11. n. 12, p. 944-948, 2018. doi: https://doi.org/10.1038/s41561-018-0244-z. 
NOGUEIRA, A. C. R; SILVEIRA, R. R.; GUIMARÃES, J. T. F. Neogene-Quaternary sedimentary and paleovegetation history of the Eastern Solimões Basin, central Amazon region. Journal of South American Earth Sciences, v. 46, p. 89-99, 2013. doi: https://doi.org/10.1016/j.jsames.2013.05.004.

OLIVEIRA, A. I. Bacia do Rio Branco: estado do Amazonas. Rio de Janeiro: Serviço Geológico e Mineralógico do Brasil, 1929. Disponível em:

https://biblioteca.ibge.gov.br/biblioteca-catalogo.html?id=251028\&view=detalhes. Acesso em: 14 jul. 2020.

PAOLA, C. Quantitative models of sedimentary basin filling. Sedimentology, v. 47, n. s1, p. 121-178, 2000. doi: https://doi.org/10.1046/j.1365-3091.2000.00006.x.

PAOLA, C.; HELLER, P. L.; ANGEVINE, C.;L. The large-scale dynamics of grain-size variation in alluvial basins, 1: Theory. Basin Research, v. 4, n. 2, p. 73-90, 1992.

PEDREIRA DA SILVA, A. J.; CUNHA LOPES, R.; VASCONCELOS, A. M.; BAHIA, R. B. C. Bacias Sedimentares Paleozóicas e Meso-Cenozóicos Interiores. In: BIZZI, L. A.; SCHOBBENHAUS, C.; VIDOTTI, R. M.; GONÇALVES, J. H. (Eds.). Geologia, tectônica e recursos minerais do Brasil. Brasília, DF: CPRM, 2003. p. 55-85.

PETTIJOHN, F. J.; POTTER, P. E.; SIEVER, R. Sand and Sandstone. New York/Berlin/Heidelberg/London/Paris/Tokyo: Springer-Verlag, 1973.

POTTER, P. E. Significance and origin of big rivers. The Journal of Geology, v. 86, n. 1, p. 13-33, 1978. doi: https://doi.org/10.1086/649653.

POTTER, P. E.; PETTIJOHN, F. J. Paleocurrents and Basin Analysis. Berlin/Heidelberg/New York: Springer, 1977.

PRESCOTT, J. R.; STEPHAN, L. G. The contribution of cosmic radiation to the environmental dose for thermoluminescence dating. In: Proceedings of the Second Specialist Seminar on Thermoluminescence Dating 6. Strasbourg, FR: Council of Europe. 1982. v. 6. p. 17-25.

PROTHERO, D. R.; CAMPBELL JR., K. E.; BEATTY, B. L.; FRAILEY, C. D. New Late Miocene Dromomerycine Artiodactyl from the Amazon Basin: Implications for Interchange Dynamics. Journal of Paleontology, v. 88, n. 3, p. 434-443, 2014. doi: https://doi.org/10.1666/13-022.

PROTHERO, D. R.; SCHWAB, F. Sedimentary geology: an introduction to sedimentary rocks and stratigraphy. 3rd ed. New York: W. H. Freeman, 2013.

PUPIM, F. N.; SAWAKUCHI, A. O.; ALMEIDA, R. P.; RIBAS, C. C.; KERN, A. K.; HARTMANN, G. A.; CHIESSI, C. M.; TAMURA, L. N.; MINELI, T. D.; SAVIAN, J. F.; GROHMANN, C. H.; BERTASSOLI, D. J.; STERN, A. G.; CRUZ, F.W.; CRACRAFT, J. Chronology of Terra Firme formation in Amazonian lowlands reveals a dynamic Quaternary landscape. Quaternary Science Reviews, v. 210, p. 154-163, 2019. doi: https://doi.org/10.1016/j.quascirev.2019.03.008.

RADAMBRASIL. Departamento Nacional da Produção Mineral, Levantamento de Recursos Naturais. Folha SA 20 Manaus. Brasília, 1978. v. 18. p. 628. 
RADAMBRASIL. Departamento Nacional da Produção Mineral, Levantamento de Recursos Naturais. Folha SA. 19 Içá. Brasília, 1977. v. 14. p. 563.

RADAMBRASIL. Departamento Nacional da Produção Mineral, Levantamento de Recursos Naturais. Folhas NA 20 Boa Vista e parte das Folhas NA 21 Tucumaque, NB 20 Roraima e NB 21. Brasília, 1975. v. 8. p. 675.

RAMOS, A. J. R. Reconhecimento geológico do território do Rio Branco. Relatório Anual do Diretor: ano de 1956. Rio de Janeiro: DGM-DNPM, 1956. p. 58-62.

REBATA, L. A. H.; RÄSÄNEN, M. E.; GINGRAS, M. K.; VIEIRA JR., V.; BARBERI, M.; IRION, G. Sedimentology and ichnology of tide-influenced Late Miocene successions in western Amazonia: The gradational transition between the Pebas and Nauta formations. Journal of South American Earth Sciences, v. 21, n. 1-2, p. 96-119, 2006. doi: https://doi.org/10.1016/j.jsames.2005.07.011.

RIBAS, C. C.; ALEIXO, A. Diversity and evolution of Amazonian birds: implications for conservation and biogeography. Anais da Academia Brasileira de Ciências, Rio de Janeiro, v. 91, supl. 3, 2019. doi: http://dx.doi.org/10.1590/0001-3765201920190218.

RIBAS, C. C.; ALEIXO, A.; NOGUEIRA, A. C. R.; MIYAKI, C. Y.; CRACRAFT, J. A palaeobiogeographic model for biotic diversification within Amazonia over the past three million years. Proceedings of the Royal Society B, v. 279, p. 681-689, 2011. doi: https://doi.org/10.1098/rspb.2011.1120.

RICE, A. H. The Rio Branco, Uraricuera, and Parima. The Geographical Journal, v. 71, n. 2, p. 113-143, 1928a. doi: https://doi.org/10.2307/1782699.

RICE, A. H. The Rio Branco, Uraricoera and Parima. Geographical Journal of London, v. 71, n. 3, p. 209-223; 1928 b.

ROSSETO, M. Proveniência sedimentar das areias holocênicas do Rio Madeira, Amazonas, Brasil. Dissertação (Mestrado em Geotectônica) - Instituto de Geociências, Universidade de São Paulo, 2013.

ROSSETTI, D. F. Paleosurfaces from northeastern Amazonia as a key for reconstructing paleolandscapes and understanding weathering products. Sedimentary Geology, v. 169, n. 3-4, p. 151-174, 2004. doi: https://doi.org/10.1016/j.sedgeo.2004.05.003.

ROSSETTI, D. F.; COHEN, M. C. L.; TATUMI, S. H.; SAWAKUCHI, A. O.; CREMON, E. H.; MITTANI, J. C. R.; BERTANI, T. C.; MUNITA, C. J. A. S.; TUDELA, D. R. G.; YEE, M.; MOYA, G. Mid-Late Pleistocene OSL chronology in western Amazonia and implications for the transcontinental Amazon pathway. Sedimentary Geology, v. 330, p. 1-15, 2015. doi: https://doi.org/10.1016/j.sedgeo.2015.10.001.

ROSSETTI, D. F.; ZANI, H.; CREMON, E. H. Fossil megafans evidenced by remote sensing in the Amazonian wetlands. Zeitschrift für Geomorphologie, v. 58, n. 2, p. 145-161, 2014. doi: https://doi.org/10.1127/0372-8854/2013/0118.

ROSSETTI, D. F.; ZANI, H.; COHEN, M. C. L.; CREMON, E. H. A Late PleistoceneHolocene wetland megafan in the Brazilian Amazonia. Sedimentary Geology, v. 282, p. 276-293, 2012. doi: https://doi.org/10.1016/j.sedgeo.2012.09.015. 
ROSSETTI, D. F.; TOLEDO, P. M.; GÓES, A. M. New geological framework for Western Amazônia (Brazil) and implications for biogeography and evolution. Quaternary Research, v. 63, n. 1, p. 78-89, 2005. doi: https://doi.org/10.1016/j.yqres.2004.10.001.

ROZO, M. G.; NOGUEIRA, A. C. R.; TRUCKENBRODT, W., 2012. The anastomosing pattern and the extensively distributed scroll bars in the middle Amazon River. Earth Surface Processes Landforms, v. 37, n. 14, p. 1471-1488. doi: https://doi.org/10.1002/esp.3249.

RULL, V. Neotropical biodiversity: timing and potential drivers. Trends in Ecology \& Evolution, v. 26, n. 10, p. 508-513, 2011. doi: https://doi.org/10.1016/j.tree.2011.05.011.

RUOKOLAINEN, K.; MOULATLET, G. M.; ZUQUIM, G.; HOORN, C.; TUOMISTO, H. River Network Rearrangements in Amazonia Shake Biogeography and Civil Security. Preprints, 2018a. doi: https://doi.org/10.20944/preprints201809.0168.v1.

RUOKOLAINEN, K.; MOULATLET, G.; ZUQUIM, G.; HOORN, C; TUOMISTO, H. Central Amazonian river avulsions. Preprints, 2018b. 10.31223/osf.io/94kdm.

SAMBROOK SMITH, G. H.; ASHWORTH, P. J.; BEST, J. L.; LUNT, I. A.; ORFEO, O.; PARSONS, D. R. The sedimentology and alluvial architecture of a large braid bar, Rio Paraná, Argentina. Journal of Sedimentary Research, v. 79, n. 8, p. 629-642, 2009. doi: https://doi.org/10.2110/jsr.2009.066.

SANT'ANNA, L. G.; SOARES, E. A. A.; RICCOMINI, C.; TATUMI, S. H.; YEE, M. Age of depositional and weathering events in Central Amazônia. Quaternary Science Reviews, v. 170, p. 82-97, 2017. doi: https://doi.org/10.1016/j.quascirev.2017.06.015.

SCHAEFER, C.; DALRYMPLE, J. Landscape evolutions in Roraima North Amazônia: plantation, paleosols and paleoclimate. Zeitschrift für Geomorphologie, v. 38, n. 1, 1995. ISSN 0372-8854.

SILVA-CAMINHA, S. A. F.; JARAMILLO, C. A.; ABSY, M. L. Neogene Palinology of the Solimões Basin, Brazilian Amazonia. Paleontographica Abteilung B, Stuttgart, v. 284, n. 1-3, p. 13-79, 2010. doi: https://doi.org/10.1127/palb/284/2010/13.

SILVEIRA, R. R. Cronoestratigrafia e interpretação paleoambiental dos depósitos Mioceno da Formação Solimões, região de Coari. Dissertação (Mestrado em Geociências) - Instituto de Ciências Exatas, Universidade Federal do Amazonas, Manaus, 2005.

SINHA, N. K. P. Geomorphic Evolutions of the Northen Rupununi Basin, Guyana. Montreal, CA: McGill University, 1968. (Savanna Research Series, 11.)

SINHA, R. The Great avulsion of Kosi on 18 August 2008. Current Science, v. 97, n. 3, p. 429-433, 2009.

SIOLI, H. (Ed.). The Amazon: Limnology and landscape ecology of a mighty tropical river and its basin. Boston: Springer, 1984. ISBN: 978-94-009-6542-3. 
SOELEN, E. E.; KIM, J.-H.; SANTOS, R. V.; DANTAS, E. L.; ALMEIDA, F. V.; PIRES, J. P.; RODDAZ, M.; DAMSTÉ, J. S. S. A 30 Ma history of the Amazon River inferred from terrigenous sediments and organic matter on the Ceará Rise. Earth and Planetary Science Letters, v. 474, p. 40-48, 2017. doi:

https://doi.org/10.1016/j.eps1.2017.06.025.

SOUZA, E. L.; GALVÃO, P. H. F.; PINHEIRO, C. S. S.; BAESSA, M. P. M.; DEMÉTRIO J. G. A.; BRITO W. R. R. 2013. Síntese da hidrogeologia nas bacias sedimentares do Amazonas e do Solimões: Sistemas Aquíferos Içá-Solimões e Alter do Chão.

Geologia USP, v. 13, n. 1, 2013. doi: https://doi.org/10.5327/Z1519$874 X 2013000100007$.

SOUZA, L. S.; ARMBRUSTER, J. W.; WERNEKE, D. C. The influence of the Rupununi portal on distribution of freshwater fish in the Rupununi district, Guyana. French Ichthyological Society - Cybium, v. 36, n. 1, p. 31-43, 2012. doi: https://doi.org/10.26028/cybium/2012-361-004.

STRICK, R. P. J.; ASHWORTH, P. J.; AWCOCK, G.; LEWIN, J. Morphology and spacing of river meander scrolls. Geomorphology, Amsterdam: Elsevier, v. 310, p. 57-68, 2018. doi: https://doi.org/10.1016/j.geomorph.2018.03.005.

TAMURA, L. N. Arquitetura e preservação de barras e depósitos de canais de grandes rios do Oeste da Amazônia Brasileira. Tese (Doutorado em Geotectônica) Instituto de Geociências, Universidade de São Paulo, São Paulo, 2019.

TAMURA, L. N.; ALMEIDA, R. P.; GALEAZZI, C.P.; FREITAS, B. T.; IANNIRUBERTO, M.; PRADO, A. H. Upper-bar deposits in large Amazon rivers: occurrence, morphology and internal structure. Sedimentary Geology, v. 387, p. 1-17, 2019. doi: https://doi.org/10.1016/j.sedgeo.2019.04.006.

TAMURA, L. N.; ALMEIDA, R. P.; TAIOLI, F.; MARCONATO, A.; JANIKIAN, L. Ground Penetrating Radar investigation of depositional architecture: the São Sebastião and Marizal formations in the Cretaceous Tucano Basin (Northeastern Brazil). Brazilian Journal of Geology, v. 46, n. 1, p. 15-27, 2016. doi: https://doi.org/10.1590/2317-4889201620150031.

TANDON, S.; SINHA, R. Geology of large rivers. In: GUPTA, A. (Ed.). Large rivers: geomorphology and management. Leeds, UK: School of Geography/Singapore: National University of Singapore, 2007[1985]. v. 2. p. 7-28. Disponível em: $<$ https://sudartomas.files.wordpress.com/2012/11/largeriversgeomorphologyandmanagement.pdf $>$. Acesso em: 12 jun. 2020.

TEEUW, R. M.; RHODES, E. J. Aeolian activity in northern Amazonia: Optical dating of Late Pleistocene and Holocene palaeodunes. Journal of Quaternary Science, v. 19, n. 1, p. 49-54, 2004. doi: https://doi.org/10.1002/jqs.815.

VAZ, P. T.; WANDERLEY FILHO, J. R.; BUENO, G. V. Bacia do Takutu. Boletim de Geociências da Petrobras, v. 15, p. 289-297, 2007. 
VEGA, A. M. L.; NOGUEIRA, A. C. R.; MAPES, R. W.; COLEMAN, D. S. Delta-lacustre do Mioceno da parte leste da Bacia do Solimões: implicações na história do rio Amazonas. In: XI Congresso da Associação Brasileira de Estudos do Quaternário, 11., 2007, Belém. Anais... Belém, 2007. Disponível em: <http://www.abequa.org.br/ trabalhos/2007_angela_maria_simposioba.pdf $>$. Acesso em: 12 jun. 2020.

VIERS, J.; RODDAZ, M.; FILIZOLA, N.; GUYOT, J.-L.; SONDAG, F.; BRUNET, P.; ZOUITEN, C.; BOUCAYRAND, C.; MARTIN, F.; BOAVENTURA, G. R. Seasonal and provenance controls on Nd-Sr isotopic compositions of Amazon rivers suspended sediments and implications for $\mathrm{Nd}$ and $\mathrm{Sr}$ fluxes exported to the Atlantic Ocean. Earth and Planetary Science Letters, v. 274, n. 3-4, p. 511-523, 2008. doi: https://doi.org/10.1016/j.epsl.2008.08.011.

WAELBROECK, C.; LABEYRIE, L.; MICHEL, E.; DUPLESSY, J. C.; McMANUS, J. F.; LAMBECK, K.; BALBON, E.; LABRACHERIE, M. Sea-level and deep water temperature changes derived from benthic foraminifera isotopic records. Quaternary Science Review, v. 21, n. 1-3, p. 295-305, 2002. doi: https://doi.org/10.1016/S02773791(01)00101-9.

WELTJE, G. J.; EYNATTEN, H. Quantitative provenance analysis of sediments: review and outlook. Sedimentary Geology, v. 171, n. 1-4, p. 1-11, 2004. doi: https://doi.org/10.1016/j.sedgeo.2004.05.007.

WILKINSON, M. J.; MARSHALL, L. G.; LUNDBERG, J. G.; KRESLAVSKY, M. H. Megafan environments in northern South America and their impact on Amazon Neogene aquatic ecosystems. In: HOORN, C.; WESSELINGH, F. P. (Ed.).

Amazônia, landscape and species evolution: a look into the past. Chichester, UK: Wiley-Blackwell, 2010. c. 10. p. 162-184. ISBN 978-1-4051-8113-6.

WILLIAMS, G. P. Paleohydrological methods and some examples from Swedish fluvial environments. II - River meanders. Geografiska Annaler, v. 66A, n. 1-2, p. 89-102, 1984. Disponível em: <https://pubs.er.usgs.gov/publication/70013338>. Acesso em: 12 jun. 2020.

WITTMANN, F.; SCHÖNGART, J.; MONTERO, J. C.; MOTZER, T.; JUNK, W. J.; PIEDADE, M. T. F.; QUEIROZ, H. L.; WORBES, M. Tree species composition and diversity gradients in white-water forests across the Amazon Basin. Journal of Biogeography, v. 33, n. 8, p. 1334-1347, 2006. Disponível em: $<$ https://www.jstor.org/stable/3838526?seq=1>. Acesso em: 12 jun. 2020.

ZALÁN, P. V. Evolução fanerozóica das bacias sedimentares brasileiras. In: MANTESSONETO, V.; BARTORELLI, A.; CARNEIRO, C. D. R.; BRITO-NEVES, B. B. (Org.). Geologia do continente sul-americano: evolução da obra de Fernando Flávio Marques de Almeida. São Paulo: Beca, 2004. p. 522-595.

ZULAR, A.; SAWAKUCHI, A. O.; CHIESSI, C. M.; D'HORTA, F. M.; CRUZ, F. W.; DEMATTÊ, J. A. M.; RIBAS, C. M.; HARTMANN, G. A.; GIANNINI, P. C. F.; SOARES, E. A. A. The role of abrupt climate change in the formation of an open vegetation enclave in northern Amazonia during the late Quaternary. Global and Planetary Change, v. 172, p. 140-149, 2019. doi:

https://doi.org/10.1016/j.gloplacha.2018.09.006. 